United States Department of Energy

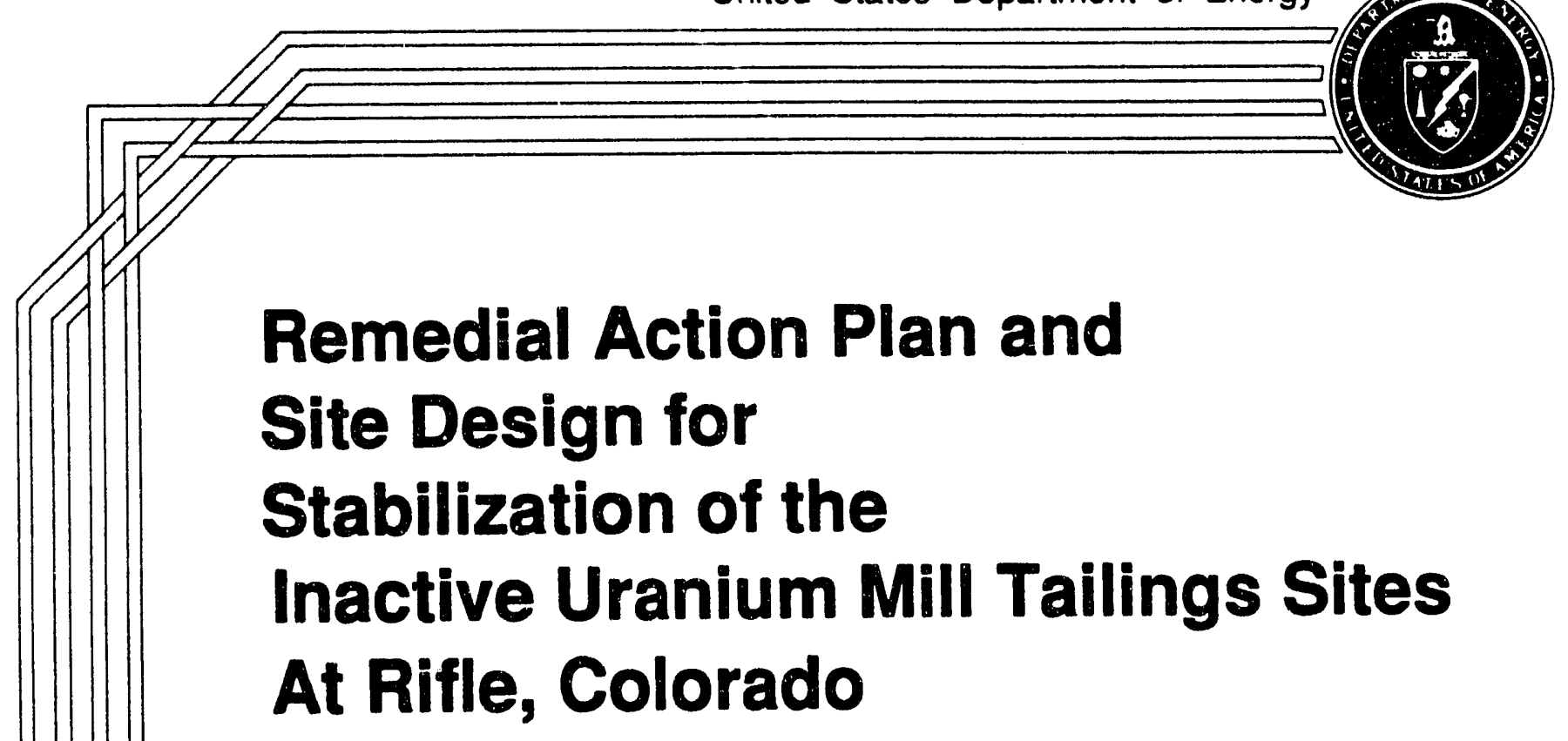

Final

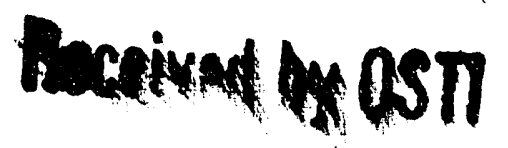

Volume III - Appendix F: Final Design, Specifications, and Drawings

$\therefore$

Appendix $B$ of the

Cooperative Agreement

No. DE-FC04-81AL16257

February 1992

Engineering drawings for this prajeat are Identified as CAPE- 3054 Inquiries may be directed to: Office of Scientific and Technical Information P. O. Box 62 Oak Ridge, TN 37831

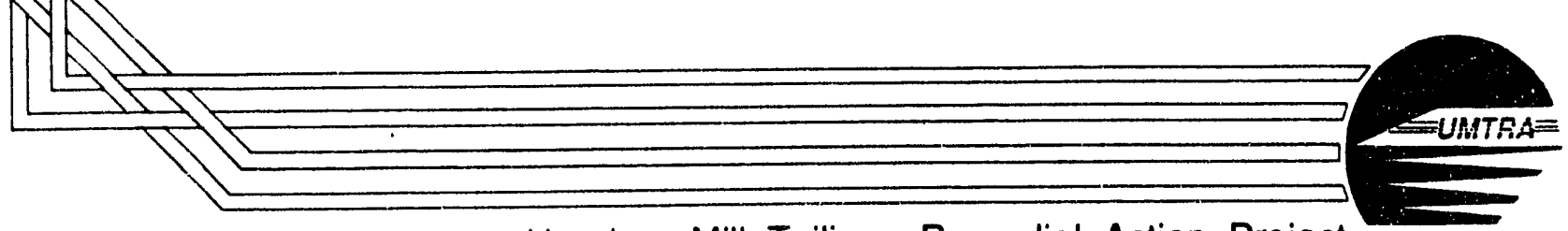

Uranium Mill Tailings Remedial Action Project 


\section{UMTRA PROJECT - RIFLE, COLORADO SUBCONTRACT DOCUMENTS RFL-PH-II ISSUED FOR CONSTRUCTION}

DECEMBER 1991

DISTREUTION OF THIO DOCUMENT IS UNELMTED 
UMTRA PROJECT

SUBCONTRACT DOCUMENTS RFL-PH-II

RIFLE, COLORADO

TABLE OF CONTENTS

\section{BIDDING REOUIREMENTS}

Section 00310, Rev. [1]* - Bid Schedule TERMS AND CONDITIONS

Section 00800, Rev. [1]* - Special Conditions

\section{SPECIFICATIONS}

DIVISION 1 - GENERAL REOUIREMENTS
Section 01010, Rev. [1]* - Summary of Work
01019, Rev. 0 - Mobilization
01025, Rev. [1]* - Measurement and Payment
01052, Rev. 0 - Layout of Work and Surveys
01300, Rev. [1]* - Submittals
01500, Rev. [1]* - Construction Facilities
01560, Rev. [1]* - Temporary Controls
01561, Rev. 0 - Construction cleaning

\section{DIVISION 2 - SITEWORK}

Section [02010, Rev. 0 - Subsurface Investigations]*

02050, Rev. [1]* - Demolition

02081 , Rev. [1]* - Asbestos, Hazardous and Non-

Hazardous [Materials] *

02090, Rev. 0 - Sealing Monitor Wells

02110, Rev. [1]* - Site Clearing

02141, Rev. [1]* - Dewatering and Drainage

02144, Rev. [1]* - Leachate Collection and Removal System

02168, Rev. [1]* - Slurry Trench

02200, Rev. [1]* - Earthwork

02216, Rev. [1]* - Ground Surface Preparation for

Disposal Cell Liner

02230, Rev. [1]* - Aggregate Base

02278, Rev. [1]* - Erosion Protection

02511, Rev. [1]* - Bituminous Pavement [Text Deleted] *

02771, Rev. [1]* - Membrane Liner

* P.I.D. 06-S-17

Document No. 3885-RFL-01-00727-04

Issued for Construction-Revision 1

Table of Contents 
DIVISION 2 - SITEWORK (continued)

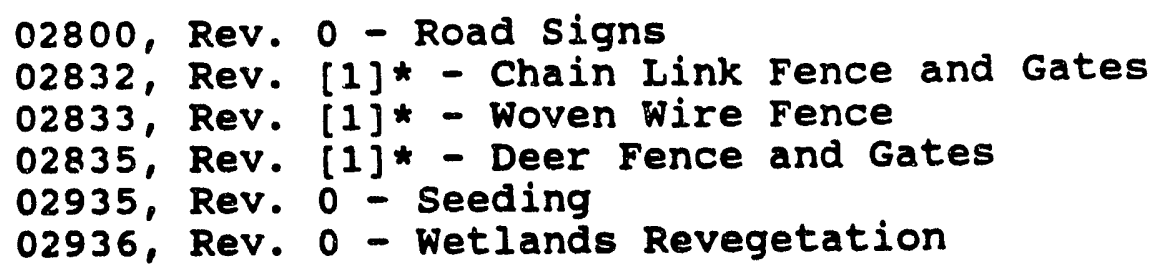

DIVISION 3 - CONCRETE

Section 03000, Rev. [1]* - Concrete Work

\section{SUBCONTRACT DRAWINGS}

\section{Drawing No.}

\section{General}

RFL-GE-10-0701, Rev. 0

RFL-GE-10-0702, Rev. [1]+

RFL-GE-10-0703, Rev. [1]+

RFL-GE-10-0704, Rev. [1]+
Title

Title sheet

Vicinity Map, Location Map, and List of Drawings

Fence and Gate Details

Potential Rock and Borrow Sources

\section{Old Rifle Processing site}

RFL-PS-10-0705, Rev. [1]+

Site Plan - Old Rifle

RFI-PS-10-0706, Rev. 0

Monitoring Well, Test Pit, Boring and Piezocone Location Plan

RFL-PS-10-0707, Rev. [1]+ Utility Removal Plan

RFI-PS-10-0708, Rev. [1]+ Excavation sequence and Tailings Excavation Plan

RFL-PS-10-0709, Rev. [1]+ Final Grading Plan

RFL-PS-10-0727, Rev. [1]+ Access from West side (Sheet 1 of 3 )

RFL-PS-10-0728, Rev. [1]+ Access from West side (Sheet 2 of 3)

* P.I.D. 06-S-17

+ P.I.D. 06-S-18

Document No. 3885-RFL-01-00727-04

Issued for Construction-Revision 1 
SUBCONTRACT DRAWINGS (Cont'd.)

Drawing No.

RFL-PS-10-0729, Rev. O

RFL-PS-10-0730, Rev. 0

RFL-PS-10-0735, Rev. [1]+

RFL-PS-10-0736, Rev. [1]+

New Rifle Processing site

RF'L-PS-10-0710, Rev. [1]+

RFL-PS-10-0711, Rev. [1]+

RFL-PS-10-0712, Rev. [1]+

RFI-PS-10-0713, Rev. [1]+

RFL-PS-10-0714, Rev. [1]+

RFL-PS-10-0734, Rev. 0

[RFL-PS-10-0738, Rev. 0

RFL-PS-10-0739, Rev. 0
Title

Access from West side (Sheet 3 of 3 )

New Decontamination Pad and Paving of Approach Roadway

slurry Trench Profile and Plan

slurry Trench Sections and

Details

Site Plan - New Rifle

Monitoring Well, Test Pit and Boring Location Plan

Utility Removal Plan and Paving of Approach Roadway

Excavation sequence and Tailings Excavation Plan

Final Grading Plan

Monitoring Well, Test Pit, Boring and Piezocone Location Plan

Excavation Plan - Vicinity Property $\mathrm{RF}-475$

Slurry Trench Plan, Profile, Sections and Details]+

Estes Gulch Disposal site RFL-DS-10-0715, Rev. [1]+ RFL-DS-10-0716, Rev. [1]+ Site Plan - Tailings Embankment Monitoring Well, Test pit and Boring Location Plan

RFL-DS-10-0717, Rev. [1]+ Access Control and Staging Area Plan and Details

+ P.I.D. 06-S-18

Document No. 3885-RFL-01-00727-04

Issued for Construction-Revision 1

Table of contents 
SUBCONTRACT DRAWINGS (Cont'd.)

Drawing No.

RFL-DS-10-0718, Rev. [1]+

RFI-DS-10-0719, Rev. [1]+

RFL-DS-10-0720, Rev. [1]+

RFL-DS-10-0721, Rev. [1]+

RFL-DS-10-0722, Rev. [1]+

RFL-DS-10-0723, Rev. [1]+

RFL-DS-10-0724, Rev. [1]+

RFL-DS-10-0725, Rev. 0

RFL-DS-10-0726, Rev. 0

RFL-DS-10-0731, Rev. [1]+

RFL-DS-10-0732, Rev. [1]+

RFL-DS-10-0733, Rev. [1]+

[RFL-DS-10-0740, Rev. 0
Title

Embankment - Foundation Excavation

Temporary site Drainage and Construction Facilities Plan

Temporary site Drainage, Retention Basin section and Details

Temporary site Drainage, Profile and sections

Final site Grading and Drainage Plan Tailings Embankment sections

Tailings Embankment Details

Permanent site Drainage, Interceptor Ditch Profile and sections

Permanent site Drainage, Toe Ditch Profile and sections

Leachate collection and Removal system $(1 / 2)$

Leachate collection and Removal System $(2 / 2)$

Gully Erosion Protection

Monitoring Well, Test Pit and Boring Location Plan Detail]+

[Text Deleted]*

END OF TABLE OF CONTENTS

* P.I.D. 06-S-17

+ P.I.D. 06-S-18

Document No. 3885-RFL-01-00727-04

Issued for Construction-Revision 1

Table of Contents 
Bid Schedule 
Following are the prices bid for completion of the work as required by the Subcontract Documents:

\begin{tabular}{|c|c|c|c|c|c|c|}
\hline $\begin{array}{l}\text { Item } \\
\text { No. }\end{array}$ & $\begin{array}{l}\text { Spec. } \\
\text { section }\end{array}$ & Description* & Unit & $\begin{array}{l}\text { Estimated } \\
\text { ouantity }\end{array}$ & $\begin{array}{l}\text { Unit } \\
\text { Price } \\
\text { (S) }\end{array}$ & $\begin{array}{l}\text { Amount } \\
\text { (\$) }\end{array}$ \\
\hline \multicolumn{7}{|c|}{ 001 - MOBILIZATION } \\
\hline 001 & 01019 & Mobilization & L.S. & $100 \%$ & $N / A$ & \\
\hline 002 & 00800 & Payment for Bond Premium & L.S. & $100 \%$ & $N / A$ & \\
\hline \multicolumn{7}{|c|}{200 - SITE PREPARATION } \\
\hline 201 & 01500 & Temporary offices & L.S. & $100 \%$ & $N / A$ & \\
\hline 202 & 01500 & $\begin{array}{l}\text { Temporary Roads and } \\
\text { Parking Areas }\end{array}$ & L.S. & $100 \%$ & $N / A$ & \\
\hline 203 & 01500 & $\begin{array}{l}\text { Temporary Sanitary } \\
\text { Facilities }\end{array}$ & L.S. & $100 \%$ & N/A & \\
\hline 204 & 01500 & $\begin{array}{l}\text { Temporary Electric } \\
\text { Power }\end{array}$ & L.S. & $100 \%$ & N / A & \\
\hline 205 & 01500 & Temporary water & L.S. & $100 \%$ & $\mathrm{~N} / \mathrm{A}$ & \\
\hline 206 & 01500 & $\begin{array}{l}\text { Maintenance and } \\
\text { Janitorial Services }\end{array}$ & Month & 50 & & \\
\hline 207 & 01500 & Snow Removal Services & Hour & 100 & & \\
\hline
\end{tabular}

[Text Deleted]**

[Item Nos. 208 thru 211 Not Used]**

** P.I.D. 06-S-17 


\begin{tabular}{|c|c|c|c|c|c|c|}
\hline $\begin{array}{l}\text { Item } \\
\text { No. }\end{array}$ & $\begin{array}{l}\text { spec. } \\
\text { section }\end{array}$ & Description* & Unit & $\begin{array}{l}\text { Estimated } \\
\text { Quantity }\end{array}$ & $\begin{array}{l}\text { Unit } \\
\text { Price } \\
(\$)\end{array}$ & $\begin{array}{l}\text { Amount } \\
(S)\end{array}$ \\
\hline 212 & 02050 & $\begin{array}{l}\text { Demolition and Disposal } \\
\text { of Structures }\end{array}$ & L.S. & $100 \%$ & $N / A$ & \\
\hline 213 & 02090 & Sealing of Monitor Wells & I.F. & 708 & 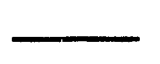 & \\
\hline 214 & 02110 & $\begin{array}{l}\text { Clearing, Grubbing and } \\
\text { Tree Removal at Estes } \\
\text { Gulch Disposal site }\end{array}$ & Acre & 112 & & \\
\hline 215 & 02168 & $\begin{array}{l}\text { slurry Trench at [old } \\
\text { and New Rifle Processing } \\
\text { Sites]** }\end{array}$ & S.F. & {$[125,500] * \star$} & & \\
\hline 216 & 02200 & $\begin{array}{l}\text { Common Excavation of } \\
\text { Uncontaminated Material } \\
\text { from Temporary Drainage } \\
\text { Ditches at Estes Gulch } \\
\text { Disposal Site }\end{array}$ & C. Y. & 36,000 & & \\
\hline 217 & 02200 & $\begin{array}{l}\text { Placement of Excavated } \\
\text { Uncontaminated Material } \\
\text { from Temporary Drainage } \\
\text { Ditch as Fill for Tem- } \\
\text { porary Drainage Ditch }\end{array}$ & C.Y. & 1,000 & & \\
\hline 218 & 02200 & $\begin{array}{l}\text { Common Excavation of } \\
\text { Uncontaminated Material } \\
\text { from Wastewater Retention } \\
\text { Basin at Estes Gulch } \\
\text { Disposal Site }\end{array}$ & C.Y. & 7,900 & & \\
\hline 219 & 02200 & $\begin{array}{l}\text { Placement of Excavated } \\
\text { Uncontaminated Material } \\
\text { from Estes Gulch Disposal } \\
\text { Site as Fill for Waste- } \\
\text { water Retention Basin }\end{array}$ & C. Y. & 33,500 & & \\
\hline 220 & 02200 & $\begin{array}{l}\text { Common Excavation of } \\
\text { Uncontaminated Soil from } \\
\text { Permanent Ditches at } \\
\text { Estes Gulch Disposal } \\
\text { Site }\end{array}$ & C.Y. & 126,200 & & \\
\hline
\end{tabular}

** P.I.D. 06-S-17 


\begin{tabular}{|c|c|c|c|c|c|c|}
\hline $\begin{array}{l}\text { Item } \\
\text { No. }\end{array}$ & $\begin{array}{l}\text { spec. } \\
\text { section }\end{array}$ & Description* & Unit & $\begin{array}{l}\text { Estimated } \\
\text { ouantity }\end{array}$ & $\begin{array}{l}\text { Unit } \\
\text { Price } \\
(S)\end{array}$ & $\begin{array}{l}\text { Amount } \\
\text { (S) }\end{array}$ \\
\hline 221 & 02200 & $\begin{array}{l}\text { Placement of Excavated } \\
\text { Uncontaminated Material } \\
\text { from Toe Ditch as Fill } \\
\text { for Toe Ditch }\end{array}$ & C.Y. & 25,500 & & \\
\hline 222 & 02230 & $\begin{array}{l}\text { Furnish and Place Aggre- } \\
\text { gate Base Course Mate- } \\
\text { rials for Access Con- } \\
\text { trol, Monitoring and } \\
\text { staging Area at Estes } \\
\text { Gulch Disposal site }\end{array}$ & C.Y. & 400 & & \\
\hline 223 & 02230 & $\begin{array}{l}\text { Furnish and Place Aggre- } \\
\text { gate Base Course Mate- } \\
\text { rials for West Access } \\
\text { Road at Old Rifle Pro- } \\
\text { cessing site }\end{array}$ & C.Y. & 60 & & \\
\hline 224 & 02230 & $\begin{array}{l}\text { Furnish and Place Aggre- } \\
\text { gate Subbase Course } \\
\text { Materials for Access } \\
\text { Control, Monitoring and } \\
\text { staging Area at Estes } \\
\text { Gulch Disposal Site }\end{array}$ & C.Y. & 1,800 & & \\
\hline 225 & 02230 & $\begin{array}{l}\text { Furnish and Place Aggre- } \\
\text { gate Subbase Course } \\
\text { Materials for West Access } \\
\text { Road at old Rifle Pro- } \\
\text { cessing site }\end{array}$ & C.Y. & 300 & & \\
\hline 226 & 02200 & $\begin{array}{l}\text { Placement of Excavated } \\
\text { Uncontaminated Material } \\
\text { from West Access Road at } \\
\text { Old Rifle Site as Fill } \\
\text { for Construction of West } \\
\text { Access Road at old Rifle } \\
\text { Site }\end{array}$ & C.Y. & 300 & & \\
\hline 227 & 02771 & $\begin{array}{l}\text { Furnish and Install Mem- } \\
\text { brane Liner for Ditches, } \\
\text { and Wastewater Retention } \\
\text { Basin Including Riprap } \\
\text { Protection at Estes Gulch } \\
\text { Disposal Site }\end{array}$ & S.Y. & 30,000 & & \\
\hline
\end{tabular}

Document No. 3885-RFL-S-01-00728-04

Issued for Construction-Revision 1

Bid schedule 


\begin{tabular}{|c|c|c|c|c|c|c|}
\hline $\begin{array}{l}\text { Item } \\
\text { No. }\end{array}$ & $\begin{array}{c}\text { spec. } \\
\text { section }\end{array}$ & Description* & Unit & $\begin{array}{l}\text { Estimated } \\
\text { Quantity }\end{array}$ & $\begin{array}{l}\text { Unit } \\
\text { Price } \\
\text { (S) }\end{array}$ & $\begin{array}{c}\text { Amount } \\
\text { (S) }\end{array}$ \\
\hline 228 & 02771 & $\begin{array}{l}\text { Furnish and Install } \\
\text { Membrane Liner for the } \\
\text { Excavation Slope at } \\
\text { Estes Gulch Disposal } \\
\text { Cell }\end{array}$ & S.Y. & {$[36,000] * \star$} & & \\
\hline $\begin{array}{l}229 \\
\text { [ ( Opti }\end{array}$ & 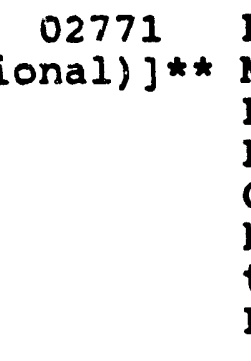 & $\begin{array}{l}\text { Furnish and Install } \\
\text { Membrane Liner for the } \\
\text { Embankment Upslope at } \\
\text { Estes Gulch Disposal } \\
\text { Cell [(Requirement will } \\
\text { be Determined by Con- } \\
\text { tractor at Time of } \\
\text { Placement of Tailings)] ** }\end{array}$ & S.Y. & {$[13,500] * *$} & & \\
\hline 230 & 02771 & $\begin{array}{l}\text { Furnish and Install Geo- } \\
\text { textile Fabric for the } \\
\text { Foundation Excavation } \\
\text { Slope at Estes Gulch } \\
\text { Disposal Cell }\end{array}$ & S.Y. & {$[39,000] * *$} & & \\
\hline $\begin{array}{l}231 \\
\text { [ (Opti }\end{array}$ & $\begin{array}{c}02771 \\
\text { ional) ]** }\end{array}$ & $\begin{array}{l}\text { Furnish and Install Geo- } \\
\text { textile Fabric for the } \\
\text { Embankment Upslope at } \\
\text { Estes Gulch Disposal } \\
\text { Cell [(Requirement will } \\
\text { be Determined by Con- } \\
\text { tractor at Time of } \\
\text { Placement of Tailings)] ** }\end{array}$ & S.Y. & {$[16,500] * *$} & & \\
\hline 232 & 02216 & $\begin{array}{l}\text { Prepare Subgrade Surface } \\
\text { for Liner Installation on } \\
\text { the Foundation Excavation } \\
\text { Slope at Estes Gulch } \\
\text { Disposal Cell }\end{array}$ & S.Y. & {$[30,000] * *$} & & \\
\hline $\begin{array}{l}233 \\
\text { [ (Opti }\end{array}$ & $\begin{array}{c}02216 \\
\text { ional)] * * }\end{array}$ & $\begin{array}{l}\text { Prepare Subgrade Surface } \\
\text { for Liner Installation on } \\
\text { the Embankment Upslope at } \\
\text { Estes Gulch Disposal cell } \\
\text { [(Requirement will be } \\
\text { Determined by Contractor } \\
\text { at Time of Placement } \\
\text { of Tailings)]** }\end{array}$ & S.X. & {$[10,000] * *$} & & \\
\hline \multicolumn{7}{|c|}{ ** P.I.D. 06-S-17 } \\
\hline RFL-PI & $H-I I$ & $\begin{array}{r}\text { Document No. } 3885-R F L- \\
\text { Issued for Constructic } \\
\text { Bid Schedul } \\
00310-4\end{array}$ & $\begin{array}{l}S-01-c \\
\text { on-ReV } \\
l e\end{array}$ & $\begin{array}{l}00728-04 \\
\text { ision } 1\end{array}$ & & $\begin{array}{r}5398 \mathrm{~S} / \mathrm{WP} \\
1219\end{array}$ \\
\hline
\end{tabular}




\begin{tabular}{|c|c|c|c|c|c|c|}
\hline $\begin{array}{l}\text { Item } \\
\text { No. }\end{array}$ & $\begin{array}{l}\text { spec. } \\
\text { section }\end{array}$ & Description* & Unit & $\begin{array}{l}\text { Estimated } \\
\text { ouantity }\end{array}$ & $\begin{array}{l}\text { Unit } \\
\text { Price } \\
(\$)\end{array}$ & $\begin{array}{c}\text { Amount } \\
(S)\end{array}$ \\
\hline 234 & 02216 & $\begin{array}{l}\text { Provide Bedding Material } \\
\text { for Liner Installation on } \\
\text { the Foundation Excavation } \\
\text { slope at Estes Gulch } \\
\text { Disposal Cell }\end{array}$ & C.Y. & {$[7,500] * \star$} & & \\
\hline $\begin{array}{l}235 \\
{[\text { (Opti }}\end{array}$ & $\begin{array}{l}02216 \\
\text { (onal) J** }\end{array}$ & $\begin{array}{l}\text { Provide Bedding Material } \\
\text { for Liner Installation on } \\
\text { the Embankment Upslope at } \\
\text { Estes Gulch Disposal Cell } \\
\text { [(Requirement will be } \\
\text { Determined by Contractor } \\
\text { at Time of Placement of } \\
\text { Tailings)]** }\end{array}$ & C.Y. & 3,500 & & \\
\hline 236 & 02800 & $\begin{array}{l}\text { Furnish and Install Road } \\
\text { signs at West Access Road } \\
\text { to old Rifle Processing } \\
\text { site }\end{array}$ & L.S. & $100 \%$ & $N / A$ & \\
\hline 237 & 03000 & $\begin{array}{l}\text { Construct Concrete Plug } \\
\text { in } 48 \text {-inch Diameter steel } \\
\text { Pipe Casing at old Rifle } \\
\text { Processing site }\end{array}$ & C.Y. & 2 & & \\
\hline $400-$ & TAILINGS & PILE & & & & \\
\hline 401 & 02200 & $\begin{array}{l}\text { [Placement into the } \\
\text { Tailings Embankment at } \\
\text { Estes Gulch Disposal } \\
\text { Site of All Excavated } \\
\text { Contaminated Materials, } \\
\text { Windblown Contaminated } \\
\text { Materials and Contami- } \\
\text { nated Vicinity Proper- } \\
\text { ties Materials from old } \\
\text { Rifle and New Rifle } \\
\text { Sites including Existing } \\
\text { stockpiles of Demolished } \\
\text { Materials and Debris]** }\end{array}$ & C.Y. [ & $4,057,000] * *$ & & \\
\hline 402 & 02200 & $\begin{array}{l}\text { [Furnish and Instal] } \\
\text { Displacement Monuments }\end{array}$ & Each & $9] * \star$. & & \\
\hline
\end{tabular}

$\star \star$ P.I.D. 06-S -17 


\begin{tabular}{|c|c|c|c|c|c|c|}
\hline $\begin{array}{l}\text { Item } \\
\text { No. }\end{array}$ & $\begin{array}{l}\text { Spec. } \\
\text { section }\end{array}$ & Description* & Unit & $\begin{array}{l}\text { Estimated } \\
\text { ouantity }\end{array}$ & $\begin{array}{l}\text { Unit } \\
\text { Price } \\
\text { (S) }\end{array}$ & $\begin{array}{c}\text { Amount } \\
(\mathbf{S})\end{array}$ \\
\hline 403 & $\begin{array}{l}02081 \\
02200\end{array}$ & $\begin{array}{l}\text { Handling and Disposal of } \\
\text { Existing stockpiles of } \\
\text { Asbestos, Hazardous and } \\
\text { Other Non-Hazardous } \\
\text { Mateials at Estes Gulch } \\
\text { Disposal Site }\end{array}$ & I.S. & $100 \%$ & $\mathbf{N} / \mathbf{A}$ & \\
\hline 404 & 02144 & $\begin{array}{l}\text { Construct Finger Drains } \\
\text { Including Furnishing and } \\
\text { Installation of Drain } \\
\text { Rock and Filter Fabric, } \\
\text { Trench Excavation and } \\
\text { Finger Drains }\end{array}$ & L.F. & {$[6,230] * *$} & & \\
\hline 405 & 02144 & $\begin{array}{l}\text { Construct Collector } \\
\text { Drains Including Fur- } \\
\text { nishing and Installation } \\
\text { of Drain Rock and Filter } \\
\text { Fabric, Trench Excava- } \\
\text { tion and Backfill for } \\
\text { Collector Drains }\end{array}$ & L.F. & {$[2,400] * *$} & & \\
\hline 406 & 02144 & $\begin{array}{l}\text { Furnish and Install } \\
\text { the Sand Blanket Drain } \\
\text { Material D2 on the } \\
\text { Bottom of Foundation } \\
\text { Excavation Surface }\end{array}$ & C.Y. & {$[9,000] * *$} & & \\
\hline 407 & 02144 & $\begin{array}{l}\text { Furnish and Install } \\
\text { Well Casing }\end{array}$ & L.F. & {$[240] * \star$} & & \\
\hline 408 & 02144 & $\begin{array}{l}\text { Furnish and Install } \\
\text { Submersible Pump and } \\
\text { operation and Mainte- } \\
\text { nance of Leachate } \\
\text { Collection and Removal } \\
\text { System for Duration of } \\
\text { the subcontract }\end{array}$ & L.S. & $100 \%$ & $\mathbf{N} / \mathbf{A}$ & \\
\hline
\end{tabular}

$\underline{500-\text { COVER }}$

50102200 Common Excavation of

Uncontaminated soil from

Foundation of Tailings

Embankment at Estes Gulch

Disposal Site C.Y. $[1,275,000] \star \star$

* * P.I.D. 06-S-17

RFL-PH-II

Document No. 3885-RFL-S-01-00728-04

Issued for Construction-Revision 1

Bid schedule 


\begin{tabular}{|c|c|c|c|c|c|c|}
\hline $\begin{array}{l}\text { Item } \\
\text { No. }\end{array}$ & $\begin{array}{l}\text { spec. } \\
\text { section }\end{array}$ & Description* & Unit & $\begin{array}{l}\text { Estimated } \\
\text { ouantity }\end{array}$ & $\begin{array}{l}\text { Unit } \\
\text { Price } \\
(S)\end{array}$ & $\begin{array}{l}\text { Amount } \\
(\$)\end{array}$ \\
\hline 502 & 02200 & $\begin{array}{l}\text { Placement of Excavated } \\
\text { Uncontaminated Material } \\
\text { as Fill for Radon Barrier }\end{array}$ & C.Y. & 144,000 & & \\
\hline 503 & 02200 & Furnish and Mix Bentonite & Ton & {$[13,600] * \star$} & & \\
\hline 504 & 02200 & $\begin{array}{l}\text { Placement of Excavated } \\
\text { Uncontaminated Material } \\
\text { as Fill for Frost Barrier }\end{array}$ & C.Y. & {$[692,000] * *$} & & \\
\hline \multicolumn{7}{|c|}{600 - EROSION PROTECTION } \\
\hline 601 & 02278 & $\begin{array}{l}\text { Furnish and Place } \\
\text { Riprap Material, Type A }\end{array}$ & C. Y. & 113,900 & & \\
\hline 602 & 02278 & $\begin{array}{l}\text { Furnish and Place } \\
\text { Riprap Material, Type B }\end{array}$ & C.Y. & 40,000 & & \\
\hline 603 & 02278 & $\begin{array}{l}\text { Furnish and Place } \\
\text { Riprap Material, Type C }\end{array}$ & C.Y. & 3,700 & & \\
\hline 604 & 02278 & $\begin{array}{l}\text { Furnish and Place } \\
\text { Riprap Material, Type D }\end{array}$ & C.Y. & 1,300 & & \\
\hline 605 & 02278 & $\begin{array}{l}\text { Furnish and Place Drain } \\
\text { Material, Type D1 }\end{array}$ & C.Y. & 77,000 & & \\
\hline 606 & 02278 & $\begin{array}{l}\text { Furnish and Place Drain } \\
\text { Material, Type D2 }\end{array}$ & C.Y. & 48,000 & & \\
\hline \multicolumn{7}{|c|}{700 - DECONTAMINATION } \\
\hline 701 & 01500 & $\begin{array}{l}\text { Decontamination Washwater } \\
\text { Recycling System, Deconta- } \\
\text { mination Pad and Facili- } \\
\text { ties, Utilities and Asso- } \\
\text { ciated Access Road at } \\
\text { Estes Gulch Disposal site }\end{array}$ & L.S. & 1008 & $N / A$ & \\
\hline 702 & 01500 & $\begin{array}{l}\text { Decontamination Washwater } \\
\text { Recycling System, Deconta- } \\
\text { mination Pad and Facili- } \\
\text { ties, Utilities and Asso- } \\
\text { ciated Access Road at } \\
\text { old Rifle Processing site }\end{array}$ & L.S. & 1008 & $N / A$ & \\
\hline
\end{tabular}

** P.I.D. 06-S-17 


\begin{tabular}{|c|c|c|c|c|c|c|}
\hline $\begin{array}{l}\text { Item } \\
\text { No. }\end{array}$ & $\begin{array}{c}\text { spec. } \\
\text { section }\end{array}$ & Description* & Unit & $\begin{array}{l}\text { Estimated } \\
\text { Quantity }\end{array}$ & $\begin{array}{l}\text { Unit } \\
\text { Price } \\
(S)\end{array}$ & $\begin{array}{l}\text { Amount } \\
\text { (S) }\end{array}$ \\
\hline 703 & 01500 & $\begin{array}{l}\text { Decontamination Washwater } \\
\text { Recycling system, Facili- } \\
\text { ties and Utilities at New } \\
\text { Rifle Processing Site }\end{array}$ & L.S. & 1008 & $\mathbf{N} / \mathbf{A}$ & \\
\hline 704 & 02511 & $\begin{array}{l}\text { Bituminous Concrete } \\
\text { Pavement for West Access } \\
\text { Road at old Rifle Pro- } \\
\text { cessing site and Access } \\
\text { Road Approach to the } \\
\text { Decontamination Pads at } \\
\text { Old and New Rifle Pro- } \\
\text { cessing Sites }\end{array}$ & Ton & 500 & & \\
\hline \multicolumn{7}{|c|}{800 - SITE RESTORATION } \\
\hline 801 & 02200 & $\begin{array}{l}\text { Common Excavation of } \\
\text { Uncontaminated Material } \\
\text { for Finish Grading of } \\
\text { Estes Gulch Disposal } \\
\text { Site }\end{array}$ & C.Y. & 90,100 & & \\
\hline 802 & 02200 & $\begin{array}{l}\text { Placement of Excavated } \\
\text { Uncontaminated Mate- } \\
\text { rial as General Fill or } \\
\text { Backfill for Finish } \\
\text { Grading of Estes Gulch } \\
\text { Disposal Site }\end{array}$ & C.Y. & 172,300 & & \\
\hline 803 & 02200 & $\begin{array}{l}\text { Placement of Excavated } \\
\text { Uncontaminated Material } \\
\text { as General Fill or Back- } \\
\text { fill for Finish Grading } \\
\text { of old and New Rifle } \\
\text { Processing Sites }\end{array}$ & C.Y. & {$[466,900] * \star$} & & \\
\hline 804 & 02200 & $\begin{array}{l}\text { Furnish and Place Coarse } \\
\text { Uncontaminated Material } \\
\text { as Fill or Backfill for } \\
\text { Finish Grading of old } \\
\text { and New Rifle Process- } \\
\text { ing Sites }\end{array}$ & C.Y. & {$[431,000] * *$} & & \\
\hline
\end{tabular}

** P.I.D. 06-S-17 


\begin{tabular}{|c|c|c|c|c|c|c|}
\hline $\begin{array}{l}\text { Item } \\
\text { No. }\end{array}$ & $\begin{array}{l}\text { Spec. } \\
\text { section }\end{array}$ & Description* & Unit & $\begin{array}{l}\text { Estimated } \\
\text { ouantity }\end{array}$ & $\begin{array}{l}\text { Unit } \\
\text { Price } \\
(S)\end{array}$ & $\begin{array}{l}\text { Amount } \\
(S)\end{array}$ \\
\hline$[804 A$ & 02200 & $\begin{array}{l}\text { Furnish and Place Uncon- } \\
\text { taminated Material as } \\
\text { General Fill or Backfill } \\
\text { for Finish Grading of old } \\
\text { and New Rifle Processing } \\
\text { sites }\end{array}$ & C.Y. & 4,700 & & {[]$^{*-1}$} \\
\hline 805 & 02935 & $\begin{array}{l}\text { Seeding of Processing } \\
\text { sites }\end{array}$ & Acre & 256.5 & & \\
\hline 806 & 02935 & $\begin{array}{l}\text { Seeding of Estes Gulch } \\
\text { Disposal Site }\end{array}$ & Acre & 11 & & \\
\hline 807 & 02935 & $\begin{array}{l}\text { Seeding of Wet Meadow/ } \\
\text { shrub Wetlands }\end{array}$ & Acre & 10.5 & & \\
\hline 808 & 02935 & $\begin{array}{l}\text { Seeding of Wetlands } \\
\text { Buffer zone }\end{array}$ & Acre & 1.8 & & \\
\hline 809 & 02936 & $\begin{array}{l}\text { Furnish and Plant } \\
\text { Sandbar willow ( } \underline{\text { Salix }} \\
\text { exigua) }\end{array}$ & Each & 315 & & \\
\hline 810 & 02936 & $\begin{array}{l}\text { Furnish and Plant Cotton- } \\
\text { wood (Populus deltoides) }\end{array}$ & Each & 45 & & \\
\hline 811 & 02936 & $\begin{array}{l}\text { Furnish and Plant Cattail } \\
\text { (Typha latifolia) }\end{array}$ & Each & 400 & & \\
\hline \multicolumn{7}{|c|}{900 - FENCING } \\
\hline 901 & 02832 & $\begin{array}{l}\text { Furnish, Install and } \\
\text { Remove Chain Link Fence } \\
\text { at Estes Gulch Disposal } \\
\text { site }\end{array}$ & L.F. & 720 & & \\
\hline 902 & 02832 & $\begin{array}{l}\text { Furnish, Install and } \\
\text { Remove Chain Iink Gate } \\
\text { at Estes Gulch Disposal } \\
\text { site, Size: } 3 \text { Ft. Long }\end{array}$ & Each & 1 & & \\
\hline 903 & 02832 & $\begin{array}{l}\text { Furnish, Install and } \\
\text { Remove Chain Link Gate } \\
\text { at Estes Gulch Disposal } \\
\text { Site, Size: } 16 \text { Ft. Long }\end{array}$ & Each & {$[4] \star \star$} & & \\
\hline
\end{tabular}

** P.I.D. 06-S-17 


\begin{tabular}{|c|c|c|c|c|c|c|}
\hline $\begin{array}{c}\text { Item } \\
\text { No. }\end{array}$ & $\begin{array}{l}\text { spec. } \\
\text { section }\end{array}$ & Description* & Unit & $\begin{array}{l}\text { Estimated } \\
\text { ouantity }\end{array}$ & $\begin{array}{l}\text { Unit } \\
\text { Price } \\
(\$)\end{array}$ & $\begin{array}{l}\text { Amount } \\
(\mathbf{S})\end{array}$ \\
\hline 904 & 02832 & $\begin{array}{l}\text { Furnish, Install and } \\
\text { Remove Chain Link Gate } \\
\text { at Estes Gulch Disposal } \\
\text { site, Size: } 20 \text { Ft. Long }\end{array}$ & Each & {$[6] \star \star$} & & \\
\hline 905 & 02833 & $\begin{array}{l}\text { Furnish, Install and } \\
\text { Remove Woven Wire Fence } \\
\text { at Estes Gulch Disposal } \\
\text { Site }\end{array}$ & L.F. & {$[12,350] * *$} & & \\
\hline 906 & 02835 & $\begin{array}{l}\text { Furnish, Install and } \\
\text { Remove Deer Fence at } \\
\text { Estes Gulch Disposal } \\
\text { site }\end{array}$ & L.F. & 2,200 & & \\
\hline 907 & 02835 & $\begin{array}{l}\text { Furnish, Install and } \\
\text { Remove Deer Gate at } \\
\text { Estes Gulch Disposal } \\
\text { Site }\end{array}$ & Each & 1 & & \\
\hline 908 & 02832 & $\begin{array}{l}\text { Furnish and Install } \\
\text { Chain Link Gate at } \\
\text { West Access Road to } \\
\text { old Rifle site, } \\
\text { size: } 20 \text { Ft. Long }\end{array}$ & Each & 2 & & \\
\hline 909 & 02833 & $\begin{array}{l}\text { Remove Woven wire Fence } \\
\text { Around office Area at } \\
\text { New Rifle Processing } \\
\text { Site }\end{array}$ & L.F. & 1,300 & & \\
\hline 910 & 02832 & $\begin{array}{l}\text { Remove Chain Iink Gate } \\
\text { From office Area at New } \\
\text { Rifle Processing Site, } \\
\text { size: } 20 \mathrm{Ft} \text {. Long }\end{array}$ & Each & 2 & & \\
\hline$[911$ & 02833 & $\begin{array}{l}\text { Furnish, Install and } \\
\text { Remove BLM Type Woven } \\
\text { Wire Fence Along Both } \\
\text { Sides of State Highway } \\
13 \text { at Estes Gulch Dis- } \\
\text { posal Site }\end{array}$ & L.F. & 8,600 & & \\
\hline
\end{tabular}

** P.I.D. 06-S-17 


\begin{tabular}{|c|c|c|c|c|c|}
\hline $\begin{array}{l}\text { Item } \\
\text { No. }\end{array}$ & $\begin{array}{l}\text { spec. } \\
\text { section }\end{array}$ & Description* & Unit & $\begin{array}{l}\text { Estimated } \\
\text { Quantity }\end{array}$ & $\begin{array}{c}\text { Unit } \\
\text { Price } \\
(S)\end{array}$ \\
\hline
\end{tabular}

91202833 Furnish, Install and

Remove Woven Wire Man

Gates Along Both Sides

of State Highway 13

at Estes Gulch Disposal site

Each

6

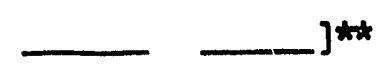

[1000 - SUBSURFACE INVESTIGATION

100102010 Backhoe Operation for

Excavation of Test Pits

and Sampling of Material Hour

80

]$^{\text {tht }}$

TOTAL (SUBCONTRACT PRICE)

$\$$

* For complete description of a Bid Item and measurement and payment provisions, see Part 4 of the specification section cited.

END OF SECTION 00310

** P.I.D. 06-S-17 


\section{Special Conditions}


SPECIAL CONDITIONS

TABLE OF CONTENTS

\begin{tabular}{ll} 
ARTICLE & \multicolumn{1}{c}{ TITLE } \\
SC-1 & DEFINITIONS \\
SC-2 & HOLIDAYS \\
SC-3 & CONSTRUCTION RESTRAINTS \\
SC-4 & SITE LOCATION AND ACCESS \\
SC-5 & COORDINATION OF WORK \\
SC-6 & CONSTRUCTION FACILITIES AND TEMPORARY CONTROLS \\
SC-7 & CONSTRUCTION ENVIRONMENT, SAFETY AND HEALTH \\
SC-8 & HEALTH PHYSICS \\
SC-9 & SUBMITTALS \\
SC-10 & QUALITY ASSURANCE \\
SC-11 & PERMITS \\
SC-12 & SUBCONTRACTOR LABOR AND EQUIPMENT RATES \\
SC-13 & SUBCONTRACT CHANGE NOTICE PROPOSAL \\
SC-14 & VARIATIONS IN QUANTITIES \\
SC-15 & LAWS AND REGULATIONS \\
SC-16 & FUNDING LIMITATIONS \\
SC-17 & CERTIFIED PAYROLLS \\
SC-18 & SUBCONTRACTOR S LIABILITY \\
SC-19 & COLORADO SALES AND USE TAX \\
SC-20 & MEASUREMENT AND PAYMENT \\
SC-21 & LIMITATIONS ON SUBCONTRACTING \\
SC-22 & BULLETIN BOARDS \\
{$[$ SC-23 } & CONTAMINATED MATERIALS HAUL INSURANCE REQUIREMENTS * \\
\end{tabular}

* P.I.D. 06-S-17 
A. Wherever used in the subcontract Documents the following terms have the meanings indicated which are applicable to both the singular and plural thereof:

1. Access Control Area - Access control area shall include the areas occupied by and in the immediate vicinity of administration facilities including, but not limited to, Contractor's and subcontractor's office trailers, access control trailer, sanitary facilities, decontamination pad and its contaminated water collection sump, equipment and materials laydown and. storage area, employee and service vehicle parking area, roadway connecting vehicular gate to decontamination pad.

2. Addenda - Written and/or graphic instruments issued prior to opening of Bids which clarify, correct or change the bidding documents.

3. ALARA - The designation 'ALARA' is an acronym for "as low as reasonably achievable".

4. Asbestos - All the asbestiform varieties of serpentinite (chrysotile), riebeckit (crocidolite), cummingtonite-granerite, anthophyllite, and actinolitetremolite.

5. Bid - The offer or proposal of the bidder submitted on the prescribed form setting forth the prices for the Work to be performed.

6. Bonds - Bid, performance and payment bonds.

7. Construction Facilities - construction facilities shall include temporary facilities required during construction phase of the permanert facilities. These facilities are specified in sertion 01500.

8. Contaminated Materials - Tailings and other materials having radioactive contamination levels greater than specified in the applicable Us Environmental protection Agency standards, or limits specified for free release of demolished materials and debris. Contamination levels, which may be based on radium, thorium or other radionuclides, shall be as determined by the contractor. These standards are presented in the Federal Register, 48FR602, January 5, 1983: "Standards for Remedial Actions at Inactive Uranium processing sites" and for demolished materials and 
A. Wherever used in the subcontract Documents the following terms have the meanings indicated which are applicable to both the singular and plural thereof:

1. Access Control Area - Access control area shall include the areas occupied by and in the immediate vicinity of administration facilities including, but not limited to, Contractor's and subcontractor's office trailers, access control trailer, sanitary facilities, decontamination pad and its contaminated water collection sump, equipment and materials laydown and storage area, employee and service vehicle parking area, roadway connecting vehicular gate to decontamination pad.

2. Addenda - Written and/or graphic instruments issued prior to opening of Bids which clarify, correct or change the bidding documents.

3. ALARA - The designation 'ALARA' is an acronym for "as low as reasonably achievable".

4. Asbestos - All the asbestiform varieties of serpentinite (chrysotile), riebeckit (crocidolite), cummingtonite-granerite, anthophyllite, and actinolitetremolite.

5. Bid - The offer or proposal of the bidder submitted on the prescribed form setting forth the prices for the Work to be performed.

6. Bonds - Bid, performance and payment bonds.

7. Construction Facilities - construction facilities shall include temporary facilities required during construction phase of the permanent facilities. These facilities are specified in section 01500.

8. Contaminated Materials - Tailings and other materials having radioactive contamination levels greater than specified in the applicable US Environmental Protection Agency standards, or limits specified for free release of demolished materials and debris. Contamination levels, which may be based on radium, thorium or other radionuclides, shall be as determined by the contractor. These standards are presented in the Federal Register, 48FR602, January 5, 1983: "Standards for Remedial Actions at Inactive Uranium Processing sites" and for demolished materials and 
b. Other subcontractor - An individual firm or corporation (other than the subcontractor) having a direct contract with the contractor for other work on the Project.

15. Notice of Award - The written notice by Contractor to the apparent successful bidder stating that upon compliance by the apparent successful bidder with the conditions precedent enumerated therein, within the time specified, Contractor will sign and deliver the Agreement.

16. Notice to Proceed - A written notice given by Contractor to subcontractor fixing the date on which the subcontract Time will commence to run and on which subcontractor shall start to perform subcontractor's obligations under the subcontract Documents.

17. Permanent Facilities - Permanent facilities shall include permanent features of the Project including, but not limited to, the following: Tailings embankment, permanent drainage ditches, finish grading and seeding.

18. Project - The total construction of which the Work to be provided under these subcontract Documents is a part as indicated elsewhere in the subcontract Documents.

19. Project site/site/Jobsite: The Project site or site shall include the areas occupied by old Rifle site, New Rifle site, windblown areas, and the Estes Gulch site.

20. Shop Drawings - All drawings, diagrams, illustrations, schedules and other data which are specifically prepared by or for subcontractor to illustrate some portion of the Work and all illustrations, brochures, standard schedules, performance charts, instructions, diagrams and other information prepared by a supplier and submitted by subcontractor to illustrate material or equipment for some portion of the Work.

21. Site Manager - The authorized representative of the contractor who is assigned to the site or any part thereof.

22. Specifications - Those portions of the subcontract Documents consisting of written technical descriptions of materials, equipment, construction systems, standards and workmanship as applied to the work and certain administrative details applicable thereto. 
23. Subcontract Change Notice/Change order - A document signed by subcontractor and contractor authorizing an addition, deletion, revision, or clarification of the Work, modified in writing and issued on or after the Effective Date of the Agreement.

24. Subcontract Drawings - The drawings which show the character and scope of the work to be performed and which are referred to in the subcontract Documents.

25. Subcontract Modification - A document issued to incorporate Subcontract Change Notices/Change Orders and adjustments in the subcontract Price or subcontract Time or to modify subcontract.

26. Subcontract Price - The moneys payable by contractor to subcontractor under the subcontract Documents as stated in the Agreement.

27. Subcontract Time - Duration of time specified in the Subcontract Agreement Form for the completion of the work under the subcontract. The time shall commence from the date or the day specified in the written Notice to Proceed, and may be specified in terms of number of calendar days available to complete the work.

28. Tailings Embankment - See Section 02200, Article 1.4.

29. Temporary Facilities - See construction Facilities in Paragraph 7 above.

30. Temporary Roads - Improvements to existing roads, and construction of new roads if any, carried out by the subcontractor for his own convenience in the performance of the subcontract.

31. Uncontaminated Materials - All materials having radioactive contamination levels less than specified in the applicable US Environmental Protection Agency Standards, or limits specified for free release of demolished materials and debris. Contamination levels which may be based on radium, thorium or other radionuclides shall be as determined by the contractor. These standards are presented in the Federal Register, 48FR602, January 5, 1983: "Standards for Remedial Actions at Inactive Uranium Processing sites" and for demolished materials and debris, in applicable limits available from the contractor. 
32. Work - The entire completed construction required under the subcontract Documents. Work is the result of performance of services, furnishing labor and furnishing and incorporating materials and equipment into the construction, all as required by the subcontract Documents.

[33. Uncontrolled Hazardous Waste Site - An area where an accumulation of hazardous substance creates a threat to the health and safety of individuals or the environment or both. Uranium mill tailings that have a total specific activity above $2000 \mathrm{pci} / \mathrm{g}$ are classified as a Hazardous substance by the Department of Transportation. ]*

B. The other terms such as Contractor, subcontractor, Government, DOE, subcontract Administrator, subcontract Documents, $M K-F$ and site of Work are defined in Article GP-2 of General Provisions.

\section{SC-2 HOLIDAYS}

A. The following days will be observed as holidays by MKFerguson company, and shall be observed by the subcontractor and lower tier subcontractors:

New Year's Day

Martin Luther King Jr.'s Birthday

Presidents' Day

Memorial Day

Independence Day

Labor Day

Thanksgiving Day

Day After Thanksgiving Day

Christmas Day

B. Holidays occurring on Saturday or Sunday will be observed on Friday or Monday.

\section{SC-3 CONSTRUCTION RESTRAINTS}

A. Concurrent Work: MK-Ferguson Company (Contractor) and other subcontractors may be engaged in work in the general areas covered by the Work under this subcontract. Such personnel will have access to the areas and to the utilities. The subcontractor shall cooperate and coordinate his work to best utilize the available areas, roadways and facilities. coordination shall be through the contractor.

*P.I.D. 06-S-17

Document No. 3885-RFI-S-01-00729-04

Issued for Construction-Revision 1

RFL-PH-II 
B. During the course of this subcontract, the contractor, and possibly state personnel, will perform radiological surveys for excavation control, and will conduct tests on excavated areas to determine whether additional contamination remains to be excavated. Results of such tests of contaminated material are generally available within four hours during normal work hours; however, test equipment constraints may increase the testing time. This does not relieve the subcontractor of his contractual obligation to place all contaminated material in the cell if additional contaminated material is found at a later date.

c. Upon apparent completion of contaminated material excavation in a distinct area, the contractor will conduct a radiological verification survey to confirm final removal of contamination to EPA standards. This survey may take up to seven work days. The subcontractor shall plan his work accordingly. The state of colorado may wish to verify the verification survey.

D. Radiological and Nuisance Dust:

1. [Proactive Dust Suppression Plan: Thirty days after receipt of Notice to Proceed the subcontractor shall submit a Proactive Dust Suppression Plan to the Contractor for approval. This plan shall include listing of specific pieces and quantity of equipment to be used, water sources, additives, days and hours of operation during construction activities, days and hours of operating during non-work periods such as between shifts, week-ends, holidays and winter shutdowrs which demonstrate the subcontractor's understanding of the importance of dust suppression requirements. It shall be adequate for all areas within the site boundaries, work areas and non-work areas, radiological and nonradiological areas. Approval of this plan does not relieve the subcontractor of any responsibilities regarding the control of dust under the terms of the subcontract.]*

2. Work Stoppage in Case of Excessive Radionuclides: [The Contractor will monitor construction activities]* and will shut down the work or require modifications of the Subcontractor's activities in the event that gaseous or particulate radionuclides exceed limits or airborne particulates are visible. Any shutdown will be a last -esort response to such conditions. Watering, vehicle speed reduction, voluntary partial shutdowns, respiratory protection and covering of materials emitting radon gas are some actions which shall be taken.

* P.I.D. 06-S-17

Document No. 3885-RFL-S-01-00729-04

Issued for Construction-Revision 1

Special conditions 
3. [Work stoppage in case of Excessive and/or Visible Dust:]* The Contractors and Subcontractor's actions regarding dust emissions in nonradiological areas within the site boundary shall be as stated above and in accordance with the contractor provided $\mathrm{CDH}$, Air Pollution Control Division - Emission Permit. [The amount or type of dust suppression equipment in operation shall not prevent the contractor from stopping work if there is excessive dust. If work stoppages occur due to excessive dust, the subcontractor shall not recommence work without approval of the contractor.]*

E. [Site speed limit of $2.0 \mathrm{mph}$ on unpaved surfaces] * shall be posted and shall be observed at all times by all construction personnel and equipment operators.

F. The subcontractor shall not be permitted to bring explosives or firearms to the sites under any circumstances without the prior approval of the contractor.

G. The subcontractor shall maintain the exhaust systems of all vehicles and equipment to protect against excessive noise and air pollution in compliance with the applicable local, state and federal requirements. The trucks shall be equipped with sound-dampening features. Tailgate chains shall be rubber-insulated and latches shall be adequately secured. Noise surveys will be conducted on all equipment by a Contractor's representative.

H. The public will have access and right-of-way to [all highways]* and city streets during the term of the subcontract.

I. If the subcontractor uncovers any archaeological artifacts or human remains during the term of the subcontract, he shall immediately halt operations in the immediate vicinity of such a discovery and notify the site Manager. Further work in these areas shall not resume until a qualified archaeologist has inspected the site and completed all resource recovery work.

j. The subcontractor shall, in as much as is practical, schedule excavation and backfill in the lower portions of the processing sites during that part of the year when the ground water level is the lowest, in order to minimize work below the ground water table. The lower portions of the processing sites are subject to inundation during periods of high water on adjacent portions of the Colorado River.

* P.I.D. 06-S-17

Document No. 3885-RFL-S-01-00729-04

Issued for Corstruction-Revision 1 special Conditions 
K. Highway 13 and the disposal site are occasionally used by stockmen when driving stock from one grazing area to another. The subcontractor shall cooperate with the stockmen in such situations and if such stock drives result in work slow downs, it will be at the subcontractor's expense.

[I. The Colorado Department of Transportaton will perform highway maintenance along the haul route on state Highways during the course of the subcontract. If colorado Department of Transportation maintenance operations result in any work slow downs or stoppages it will be at the Subcontractor's expense.]*

SC-4 SITE LOCATION AND ACCESS

A. Location:

1. The work under the subcontract involves operations at three different sites:
a. Old Rifle Processing site
b. New Rifle Processing site
c. Estes Gulch Disposal Site

2. The locations of these sites are specified in specification section 01010.

B. Access: The liability insurance dictates mandatory enforcement by the Contractor of the following restraints to all persons seeking construction site access:

1. Private, personal or agency vehicles not used for authorized construction purposes will not be allowed in the controlled site areas.

2. Parking of private, personal or agency vehicles shall be in a restricted area outside of the controlled site areas as designated by the site Manager or his representative.

SC-5 COORDINATION OF WORK

The subcontractor shall carefully coordinate all construction activities with the site Manager to avoid conflicts and unnecessary delays in construction.

* P.I.D. 06-S-17 
A. Unless otherwise specified elsewhere in the subcontract Documents, the subcontractor shall furnish and assume full responsibility for the following facilities and incidentals which are necessary for the furnishing, performance, testing, start-up and completion of the Work as shown on the subcontract Drawings and as specified in the specifications:

1. All materials, equipment, plant, labor, transportation, construction equipment and machinery, tools, appliances, fuel, power, light, heat, telephone, water, sanitary facilities, decontamination facilities and all other facilities and incidentals as specified in section 01500 .

2. Temporary controls including, but not limited to, dust control, erosion control, noise control, poliution control, surface water control and access and traffic control as specified in section 01560 .

B. Subcontractor shall be responsible for installing, constructing, maintaining, operating, removing and disposing of the construction facilities and temporary controls through the term of the subcontract.

SC-7 CONSTRUCTION ENVIRONMENT, SAFETY AND HEALTH

A. Contractor Safety Program:

1. The subcontractor shall comply with the construction Environment, Safety and Health Management Program (Document No. MK-UMTRA-4). (A condensed version of this document is provided at the end of this section.]*

2. The successful bidder will be issued a copy of the Construction Environment, Safety and Health Management Program Document with the Notice to Proceed by the Contractor's Subcontract Administrator.

3. A table of contents for the Construction Environment, Safety and Health Management Program is listed below:

* P.I.D. 06-S-17 
PAGE REV.\#

Table of Contents

i

1

MK-F Accident Prevention Policy

iii 1

CNSI Corporate Safety Policy

iv 1

Construction subcontractor Safety Policy

Regulations and standards

vi

11

Purpose

Remedial Action Contractor organization

Subcontractor organization

2

1

III

IV

Scope of Responsibilities

a. Remedial Action Contractor

b. Subcontractors

c. Employees

V

Inspection and Enforcement

81

VI

Audits

91

VII

Fire Prevention and Protection

$10 \quad 1$

VIII

First $A$ id and Medical Program

13

1

IX

Remedial Action Contract Records and Reports

17

1

Subcontractor Records and Reports

24

1

Emergency Action

30

1

Safety and Health Training Program

32

35

1 
XIV

Environmental Control and Monitoring

36

37

Access Control

Industrial Hygiene

Job Safety Analysis

XVIII
General Safety and Health Procedures

\section{APPENDICES}

REV.\#

Appendix A Posters, Records and Reporting Forms

62

1

Appendix B Job Safety Analysis

64

1

Appendix C Project Forms and Distribution Table
1

1

1

1

1

4. The subcontractor shall comply with radiological programs and procedures required in the current revisions of the RAC/MK-F Health Physics Procedures, Health Physics Monitoring Plan, the Site Specific Health Physics Monitoring Plan, and/or DOE orders as applicable. Copies of these documents will be provided by the contractor on request of the subcontractor.

B. Construction Environment, Safety and Health Initial Indoctrination and Training:

1. All construction personnel working on the site shall receive the basic Construction Environment, safety and Health Initial Indoctrination and Training. The Indoctrination and Training will cover such matters as first aid and medical responsibilities, emergency actions, etc. [The indoctrination may be oral or written and/or audio visual (approximately 30 minutes in length). It will be presented to construction personnel either individually or on a group basis and at the subcontractor's convenience. The indoctrination will be presented to all personnel upon request at the site office, between the hours of $8: 00 \mathrm{a} . \mathrm{m}$. and 4:00 p.m., Monday through Friday (holidays excluded). No construction personnel will be permitted to work without having received this basic indoctrination. ]*

P.I.D. 06-S-17 
2. All employees shall have a written medical qualification to wear a respirator before they can perform work which requires the use of a respirator. Based upon requirements in OSHA 29 CFR 1910.134 and criteria established by the Contractor's Medical Director, and upon recommendations listed in the American National standards Institute, ANSI 288.2-1980, "Practices for Respiratory Protection", all employees who will or may be required to wear respirators on this project shall complete a medical questionnaire and will be given pulmonary function and blood pressure tests by the contractor before initial assignment and annually thereafter. This information will be evaluated by the Contractor's Medical Director between the hours of $8 \mathrm{a} . \mathrm{m}$. and $4 \mathrm{p} . \mathrm{m}$., Monday through Friday, and if it is determined to meet specific criteria, a written qualification to safely wear a respirator will be issued to the employee within 24 hours, upon receipt of the information. If a written gualification is not issued by the Contractor's Medical Director, the subcontractor is responsible for scheduling and payment of any additional medical evaluations, and shall submit to the site Manager a written medical release for their employees' use of respirators.

3. No payment will be made to the subcontractor for his employees' attendance at safety and Health Initial Indoctrination and Training Program or respirator training provided by the contractor. Full compensation for such costs will be considered incidental to the work of this subcontract.

4. [A]l employees not subject to the medical surveillance requirements of OSHA Standard 29 CFR 1910.120 shall have a written medical qualification to wear a respirator before they can perform work which requires the use of a respirator. If respirator use becomes necessary, for radiological protection, the respirators will be provided by the contractor with training in the proper use to perform specific tasks.]* This instruction is approximately two hours long but may vary with class size and will be provided to the subcontractor at no extra cost. The Subcontractor shall notify the contractor's Representative at least one (1) week in advance of the time that the training is desired. Note, that individuals with beards or facial hair that interferes with a proper respirator seal will not be accepted for respirator training. Respirators and training for any other kind of protection shall be furnished by the subcontractor.

* P.I.D. 06-S-17

Document No. 3885-RFL-S-01-00729-04

Issued for Construction-Revision 1 Special Conditions 


\section{c. Electrical Precautions:}

1. Personnel Ground Fault protection: All electrical conductors used in construction, operating on single phase, 120 VAC, 15 or 20 amperes circuits, shall be equipped with UL listed Ground Fault circuit Interrupters set at five (5) milliamperes plus $(+)$ or minus (-) one (1) milliampere. All electrical conductors, portable electric tools and their identification, installation and usage shall be in compliance with applicable OSHA standards set forth in section 29 CFR 1926.404 of the OSHA 2207 construction industry publication.

2. Electrical clearance Requirement: All electrical circuit connections shall be made on de-energized systems. Working clearance for energized systems shall be 3 feet for 0 to 150 volts and 4 feet for 151 to 600 volts. The work shall be performed by a qualified journeyman electrician or by an apprentice electrician under the direct supervision of a qualified journeyman electrician.

D. Smoking, Drinking, Eating and Chewing Restrictions: No smoking will be permitted in the immediate vicinity of any flammable liquids, gases or highly combustible material, or in any area posted as a non-smoking area. No smoking, drinking, eating or chewing will be permitted in any controlied area.

E. LLadders, Scaffolds, Man Lifts and Stairways: All man-lift equipment, ladders, scaffolding and stairways shall be in compliance with applicable OSHA (29 CFR 1926) standards and be subject to inspection by the contractor prior to and during its use.]*

F. Trench/Excavation Barricades:

1. Trenching, excavation, shoring, bracing, and barricading requirements shall be in accordance with OSHA standard, 29 CFR 1926, Subpart $P$, revision effective January 2 , 1990 .

2. The following forms of protection shall be required for open trenches/excavations adjacent to occupied buildings, crossing pedestrian crosswalks and paths, at street intersections, and crossing or adjacent to sidewalks and driveways:

เP.I.D. 06-S-17 
a. Barricades shall be positioned on each side of the trench and stationed at a maximum of ten (10) foot intervals. Spacing on each side of the trench shall alternate to show that a front view depicts barricades at five (5) foot intervals.

b. Whenever possible, each barricade shall be positioned at least two (2) feet away from the open trench or excavation.

c. Each barricade shall be equipped with a yellow flasher of at least eight (8) inches in diameter. (NOTE: Temporary barricades used during daylight operations do not require flashers.) street side flashers shall be directed parallel with the street, curb side flashers and flashers along pedestrian routes shall be facing in the direction of pedestrian traffic.

d. When continuous solid barricades are not provided, interconnecting ropes or tape shall be attached to all barricades. When rope is used, streamers shall be attached at $2-3$ foot intervals.

e. Walkways and/or bridges with standard guard rails, shall be provided at all pedestrian crossing points except for trench width $2^{\prime}-0^{\prime \prime}$ and less where a barricade straddling the trench on either side of the walkway may be used.

f. Where vehicle traffic must cross trenching operations, metal plate covers shall be provided to support all motor vehicles.

g. Where trenches or excavations interrupt a doorway, ramp, or other exits/entrances to buildings, the doors shall be locked or blocked and a sign displayed to indicate the condition that exists.

G. Notification of Occurrences: Subcontractor shall advise the Contractor immediately upon occurrence of any non-routine events, occurrences, incidents, truck spilis of contaminated materials, or accidents, etc., particularly in situations such as lost time accidents and ambulance calls.

H. Responsibility:

1. Subcontractor Safety Responsibility:

a. The subcontractor shall designate in writing a qualified person to implement at all times the 
Construction Environment, Safety and Health Management Program at the work site. The designated person shall have authority for actions and for control of work activity to prevent accidents. [The subcontractor's safety representative shall be a full-time employee whose responsibility is to implement the construction Environment, safety and Health Management Program and who reports directly to the subcontractor's management.]* [Text Deleted]* The contractor reserves the right to reject any safety person designated by the subcontractor and considered unqualified by the contractor. [At times when the subcontractor's designated safety Representative is not available (sick, vacation, day-off, seminar, etc.), an alternative representative acceptable to the contractor shall fulfill all the responsibilities of the Safety Representative.]*

b. [The subcontractor's Safety Representative shall make daily work area safety and health inspections when any work is ongoing. Such daily inspections shall be documented in writing and shall include a brief description of the inspection findings, deficiencies noted and actions taken or implemented as a result. Copies of the documented inspections shall be submitted to the contractor on a weekly basis.]*

2. Contractor safety Responsibility:

a. Contractor safety Department personnel or designated representatives will make regular continuing inspections of all facilities and operations within the scope of the subcontract. These inspections will include the facilities and all operations of the subcontractor, but do not in any way relieve the subcontractor of his responsibility for compliance with the provisions of the construction Environment, Safety and Health Management Program.

b. Daily work area safety and health inspections will be made by Contractor personnel.

I. Galvanized Materials: Personal respiratory protection or ventilation is required if a heat process takes place with galvanized materials.

* P.I.D. $06-S-17$

Document No. 3885-RFL-S-01-00729-04

Issued for Construction-Revision 1 Special Conditions 
J. Back Up Alarms: All construction equipment shall have functioning audible back up alarms while in use on an UMTRA project.

K. Asbestos: The subcontractor shall submit the following to the Contractor for review before work start up:

1. A Certificate of Insurance Coverage, including, but not limited to, the following. These insurance coverage requirements are supplemental to other requirements specified in Article GC-7 of the General Conditions.

a. Asbestos Exclusions on Workmen's Compensation or Liability policies will not be accepted. However, separate policies will be satisfactury.

b. Whether coverage is on an occurrence or claims made basis, it is required that the coverage or policy be extended or kept in force for at least twentyfour (24) months after completion of the subcontract.

c. The subcontractor shall provide evidence of coverage by submitting a certificate of Insurance stating that such exclusions or coverage are in effect.

2. An asbestos plan for the transportation and burial of asbestos materials stockpiled on site. The asbestos materials shall be buried in the disposal cell using acceptable cell design criteria. Asbestos materials shall be buried and covered with at least 12 inches of compacted soil within 24 hours of transportation to the cell. An Asbestos Handling and Removal Plan shall be required if asbestos materials are uncovered during site excavations. The detailed requirements for submittal of the Asbestos Handing and Removal Plan are specified in section 02081.

3. Asbestos Removal Permit: See Article SC-11.B.

L. Unidentified Waste Materials: Unidentified wastes will be identified by the contractor through laboratory analysis. If the materials are identified as hazardous, the subcontractor shall comply with the applicable standards for personnel safety and health protection. 
M. Industrial Hygiene:

1. Noise:

a. The UMTRA Project shall comply with the OSHA Construction Occupational Noise Exposure Regulation 29 CFR 1926.52. Sound level surveys and noise dosimetry will be conducted by the Contractor for both the contractor and Subcontractor personnel. Noise monitoring data will be available to the subcontractor for evaluation. Hearing protection is required for any personnel exposed to $85 \mathrm{~dB}(\mathrm{~A})$ or above. Iimit applies for an 8 -hour time weighted average.

b. The subcontractor shall provide baseline and annual audiometric testing (hearing tests) if it is possible to annualiy track employees, and shall provide training to any employee exposed above 85 $\mathrm{dB}(\mathrm{A})$ 8-hour Time Weighted Average (TWA), as required to have an effective hearing conservation program. The baseline audiometric test shall be given to employees within 6 months of hire date. Costs of audiograms and training shall be funded by the subcontractor without cost to the employee. subcontractors or their individual employees, who work on an UMTRA site for less than 6 months are not required to perform audiometric tests for purposes of this subcontract. Details are given in Section 02081 .

c. The contractor will ensure subcontractor compliance with the OSHA 29 CFR 1926.52 regulation by reviewing subcontractor records and interviewing subcontractor employees as necessary.

d. The subcontractor shall comply with the state of colorado statutes 25-12-101 (revised) and amendment regarding noise standards.

[e. Trucks engaged in hauling activities shall not use engine brakes except in emergencies.]*

2. Dust: subcontractor's dust control provisions shall be adequate to prevent personnel from potential inhalation exposure to silica or Nuisance Particulates and to keep Total suspended Particulates (TSP) below 150 micrograms

$\star$ P.I.D. 06-S-17

Document No. 3885-RFL-S-01-00729-04

Issued for construction-Revision 1

Special conditions

5400 /WP51

RFL-PH-II

$00800-18$

121991 
per cubic meter as required by colorado Air Pollution Control Division. TSP monitoring will be performed around the site boundaries by the contractor and the data will be provided to the subcontractor. Contractor's Safety Department will conduct ongoing dust monitoring and will keep the subcontractor informed about the need for respiratory protection. The subcontractor shall provide dust masks or the necessary respiratory protection for silica where radiological contamination is not present.

3. Prior to confined space entry, the subcontractor shall read and comply with the conf ined space entry procedures developed by the contractor. The procedures require that a permit be completed and kept at the work place. Atmospheric testing will be performed prior to confined space entry for percent oxygen, Carbon Monoxide, Combustibles and Hydrogen Sulfide. Testing will be done using a direct reading instrument assigned to the Contractor's Health and Safety personnel.

4. Hazard Communication: The Subcontractor shall comply with the OSHA Hazard Communication Program for the Construction Industry. The required compliance activities include but are not limited to:
a. Current-Chemical Inventories
b. Material Safety Data Sheets for all Chemicals
c. Proper labeling of all chemical containers.
d. Complete written program available to all work place employees.
e. Appropriate training to all employees on hazards of the workplace as required in OSHA 29 CFR 1926.59.

5. General Hazards: The subcontractor shall be responsible for controlling general hazards as identified by the Contractor. General hazards include heat stress, ultra violet radiation, chemical exposures and biological agents with potential to cause illness or injury to site personnel.

N. Construction Motor Vehicles, Heavy Equipment and Machinery Inspections and Maintenance:

1. General: Prior to the operation of any vehicles or equipment, the Subcontractor shall notify the offices of the County Clerk and County Assessor and provide certification of licensing and assessment of all construction vehicles and equipment. 
2. Construction Motor Vehicles:

a. Vehicles that are in operation within an offhighway jobsite shall comply with 29 CFR 1926.601.

b. Vehicles that operate on highways or any public roads shall comply with the North American Uniform Out-of-Service Criteria (which the Subcontractor is responsible for obtaining). (In addition, the subcontractor shall implement and comply with all requirements of the contractor's Truck Inspection Plan. ]*

c. Inspection reports and repair records shall be submitted to the Contractor's Site Manager prior to the initial use of all Motor Vehicles. Any additional inspection reports or repair records as required by the Truck Inspection Plan shall also be submitted to the site Manager.

[d. Truck Information: All haul unit vehicles shall be equipped with a system that will:

1) Monitor driver trends, habits, routes and equipment. Identify high risk driver activity. Identify when vehicle exceeds operating parameters.

2) Monitor fuel economy, speed, idle time and RPM's.

3) Present data in a clear, user friendly report format that separates driver and vehicle information.

All trucks carrying contaminated materials shall be connected to a radio communications system.

e. Any or all data shall be provided to the Contractor within 24 hours upon request.]*

3. Heavy Equipment and Machinery:

a. The subcontractor shall designate a competent person to inspect the operating safety conditions of all construction Heavy Equipment and Machinery. The Heavy Equipment and Machinery shall be inspected prior to their use and frequently during their use to make certain that they are in safe

* P.I.D. 06-S-17

Document No. 3885-RFL-S-01-00729-04

Issued for Construction-Revision 1

RFL-PH-II

Special Conditions

$00800-20$ 
operating condition. All deficiencies shall be repaired and defective parts replaced before continued use of the equipment or machinery. Records of inspections and repairs shall be maintained by the subcontractor and be submitted weekly to the contractor.

b. A thorough annual inspection of the hoisting mavhinery shall be made by a competent person or by a government or private agency recognized by the U.S. Department of Labor, and inspection reports shall be maintained.

c. Inspection reports and repair records shall be submitted to the Contractor's site Manager prior to the use of such construction vehicles, machinery and equipment on the project.

d. Material handling Heavy Equipment shall comply with 29 CFR 1926.602 .

[0. Hazardous Waste Operations (OSHA Standard 29 CFR 1910.120):

1. Training Requirements:

a. All subcontractor employees who are expected to work full-time, part-time or routinely on-site, and are exposed to hazardous substances (i.e. uranium mill tailings above $2000 \mathrm{pci} / \mathrm{g}$ total specific activity), or other health and safety hazards shall complete 40 hours of initial training, or equivalent, prior to working on-site. These employees shall be provided with an additional three days of on-the job training by a trained supervisor.

b. The contractor will provide all subcontractor employees affected by subparagraph a with approximately eight (8) hours of site speciric safety and health training. This 8 hours of training is considered "equivalent training" and is applicable to the 40-hour training requirement. The subcontractor shall apply this 8 hours of training towards the required 40-hour training for each affected employee. The general contents of the 8 hours of training include:

1) Initial ES\&H Indoctrination - which addresses site rules and requirements: one (1) hour.

2) Hazard Communication Training - in compliance with OSHA 29 CFR 1926.59: One (1) hour.

Document No. 3885-RFL-S-01-00729-04

Issued for Construction-Revision 1

special Conditions 
3) Respiratory Protection Training - for airpurifying respirators as required by OSHA 29 CFR 1910.134: Two (2) hours.

4) Radiation Protection Worker Training - which addresses radiation safety, effects of exposure, health risks, dose, protection measures, instrumentation, decontamination, emergency procedures, and responsibilities: Four (4) hours.

c. In addition to the 40 hours of initial training, the subcontractor shall provide 8 hours of supervisor training to all management and supervisory personnel.

d. The subcontractor shall provide all employees specified in paragraphs $1 . a$ and $1 . b$ with 8 hours of rerresher training annually. This training is required on or before the anniversary date of the initial training.

e. All training required by this special condition shall comply with the occupational safety and Health Administration (OSHA) Standard $\approx 9$ CFR 1910.120 entitled "HAZARDOUS WASTE OPERATIONS AND EMERGENCY RESPONSE".

f. Should the subcontractor perform work on-site with employee(s) who are not appropriately trained, a written submittal shall be provided to the Contractor for approval prior to commencement of this work. This submittal shall provide details as to the type and duration of the work, and certify that the work is to occur in a non-exclusion area that is free of exposures to hazardous substances, health hazards, or safety hazards.

g. Site visitors, vendors, auditors and others who are not full-time, part-time, or routine site workers will not be required to complete training as required in OSHA Standard 29 CFR 1910.120 provided they are escorted on-site at all times by project personnel who are knowledgeable of the exclusion and non-exclusion areas, and provided they are not exposed to hazardous substances, health hazards or safety hazards. All site visitors, vendors, auditors and others shall be given initial ES\&H indoctrination training by the contractor prior to site entry. 
2. Medical Surveillance Requirements:

a. The subcontractor shall provide medical surveillance for all subcontractor employees who: 1) are or may be exposed to a hazardous substance (i.e. uranium mill tailings above $2000 \mathrm{pci} / \mathrm{g}$ total specific activity), or health hazards at or above the permissible exposure level (PEL), or, if there is no PEL, above the published exposure levels for these substances, without regard to the use of respirators, for thirty days or more a year; or 2) who wear a respirator for thirty days or more a year; or 3) who are injured due to overexposure from an emergency incident involving hazardous substances; or 4) who are members of a HAZMAT Team. The Subcontractor shall submit to the contractor a written explanation which provides justification for any employees who are not included in the medical surveillance program.

b. The subcontractor shall provide employees who require medical surveillance with examinations at the following times: 1) before initial assignment; 2) every twelve months unless the attending physician believes a shorter or longer interval is appropriate (in no case shall the surveillance duration be greater than every two years); 3) at termination of employment from the Uranium Mill Tailings Remedial Action Program unless an examination has occurred within the last six months; 4) immediately when an employee develops symptoms of overexposure to a hazardous substance or health hazard, or is injured or exposed above accepted levels in an emergency situation.

c. The Subcontractor shall ensure medical examinations are either provided or supervised by a qualified licensed physician. The subcontractor shall provide, at a minimum, the following information to the attending physician: 1) A Copy of OSHA Standard 29 CFR 1910.120; 2) A description of the employee's duties as they relate to the employee's exposure; 3) A copy of the employee's actual or potential exposure levels; 4) A description of the types of personal protective equipment (PPE) used on-site, including respiratory protection; 5) A copy of the employee's past medical examination if requested by the physician.

d. The physician shall perform, at a minimum, a medical and work history, and an examination that

Document No. 3885-RFL-S-01-00729-04

Issued for Construction-Revision 1

Special Conditions

5400 S/WP5 1

$00800-23$

121991 
is representative of the site hazards including fitness for duty with an emphasis on the ability of the employee to wear an air-purifying respirator and other PPE under stressful conditions such as hot weather and physical work.

e. The physician shall provide the subcontractor with a written statement in compliance with OSHA standard 29 CFR 1910.120 that qualifies or disqualifies the employee on their ability to work on-site. This qualification statement shall specifically address the employee's ability to wear an air purifying respirator. The subcontractor shall provide a copy of this written statement to the employee and to the contractor. Employees not qualified to work under the conditions considered in the examination will not be allowed to perform job duties on-site.

f. The subcontractor shall comply with all provisions of OSHA Standard 29 CFR 1910.120, unless more stringent requirements are described or referenced in this document. The contractor will determine on-site exclusion and non-exclusion areas.

3. Record Keeping Requirements:

a. The subcontractor shall submit to the contractor, on the first business day of every month, a complete roster of personnel which lists the following information and accomplishments which comply with OSHA standard 29 CFR 1910.120, if applicable:

- Name

- Social Security Number

- Site Name

- Date of Initial 40-Hour Training Course

- Date of Annual 8-Hour Refresher Training Course

- Date of 8-Hour Supervisor Course

- Date of Initial Medical Examination

- Date of Annual Medical Examination

- Date of Exit Medical Examination

- Date of Three Day On-The-Job Training

- Date of Employment Termination 
b. The subcontractor shall issue a card to all employees which certifies that they are currently trained and are qualified under the medical examination requirements. The subcontractor shall ensure each employee has this card readily available for contractor compliance audits.

4. Responsibility: The subcontractor is responsible for providing all scheduling and implementation activities related to OSHA Standard CFR 1910.120 and Special Conditions Article SC 7.0. This ensures that employees are trained and medically qualified prior to job assignment. These activities are incidental to the work and there will be no separate payment. In addition, prior costs related to these training and medical examinations which were determined to be unnecessary are not recoverable.]*

\section{[SC-8 HEALTH PHYSICS}

Portions of the subcontract work area are located in radiologically controlled area. All work shall be governed by the essential requirements given in the following paragraphs:

A. Health Physics (HP) Personnel: The site Manager will monitor the construction work through HP personnel employed by him. The HP personnel will provide radiological surveillance over construction activities and advise supervision on matters concerning radiation safety as related to activities or conditions affecting the construction work.

B. Radiologically Controlled Areas:

1. The contractor will perform radiological base line surveys of all haul routes outside of controlled areas as required. At a minimum, the surveys shall be performed prior to initial haul activities and winter shut down period. The base line surveys shall be performed on an annual basis. The subcontractor shall remove and properly dispose of any contaminated materials detected from the base line surveys immediately. The work shall include clean-up and restoration as required by the contractor.

* P.I.D. 06-S-17 
2. Radiologically controlled areas shall be established as needed at the discretion of the site Manager. They will normally include areas where radioactive contamination levels exceed 10 times the applicable limits or where airborne radioactive material concentrations or external radiation dose exceed the applicable limits.

3. The contractor will provide HP personnel to control access to radiologically controlled areas.

4. The subcontractor shall provide access control facilities as specified in section 01500.

5. All personnel will be required to sign in and sign out of radiologically controlled areas, including but not limited to name, time and areas where they worked.

6. No eating, drinking, smoking, or chewing will be allowed in a radiologically controlled area. Personnel found to be in violation of this rule may be restricted from the controlled area, and/or have their training certification revoked.

7. All personnel will be required to self-monitor (frisk) for radioactive contamination upon leaving the controlled area. Personnel will be instructed in selfmonitoring procedures as a part of the Radiation Worker Training.

8. The subcontractor shall observe controlled area restrictions and shall take applicable precautions.

9. Dust suppression techniques are required to limit exposure to airborne radionuclides.

C. Protective clothing for contamination control:

1. Protective clothing may be utilized for contamination control at the discretion of the contractor.

2. When required, protective clothing may consist of coveralls, gloves, rubber boots, shoe covers, and/or respirators in any combination.

3. Protective clothing will be provided to the subcontractor at no charge on a loan basis.

4. Protective clothing will be issued by contractor personnel at the access control area. Protective clothing shall be put on and removed at the access control area or radiologically controlled area boundary.

Document No. 3885-RFL-S-01-00729-04

Issued for construction-Revision 1 Special coñitions 
Personnel will be required to change out of the protective clothing prior to leaving the controlled area.

5. Respiratory protection may be required during certain construction activities due to airborne radionuclide or radon gas concentrations. The contractor's access control personnel will specify when and where respirators are required.

6. The subcontractor shall ensure that protective clothing items are stored in a weatherproof facility inside the controlled area boundary and that storage areas are maintained in proper order. Access control trailers specified in section 01560 may be used for storage of protective clothing.

7. Compliance with required protective clothing standards is mandatory.

D. Training Requirements:

1. All personnel whose job assignment requires work on, with, or in the proximity of radioactive materials (mill tailings) will be trained as Radiation workers.

2. The Radiation Worker training course is approximately four hours long.

3. The Radiation Worker training course is available to subcontractor personnel at no cost for the instruction. The subcontractor shall notify the contractor's representatives at least one day in advance when training is desired.

4. A test will be given to all personnel at the conclusion of training to establish qualifications as a Radiation Worker. Personnel must pass this test to work within the radiation control area.

5. Training in the proper use of respirators for performing specific tasks may be required. For respirator training and employee requirement, see Articles SC-7.B.2 and SC -7.3 .4 .

E. Radiation Exposure Limits and Dosimetry:

1. Radiation exposure on the UMTRA Project is expected to be well within allowable radiation exposure limits.

Document No. 3885-RFL-S-01-00729-04

Issued for Construction-Revision 1 special Conditions 
2. Prior to working at the construction site each employee shall provide prior radiation exposure records as applicable.

3. Whole body radiation exposure shall be determined by the use of Personal Thermoluminescent Dosimeters (TLD). The contractor will provide TLDs as required.

4. While working at the construction site, each employee who is issued a TLD is required to wear that TLD. TLDs will be issued and collected upon entrance to and exit from the controlled area.

5. No one under the age of 18 shall be permitted to enter or work in the controlled area.

F. Bioassay (Urine and/or Fecal Samples):

1. Employees working in radiation control areas may be required to submit an initial, quarterly, and termination bioassay sample.

2. Employees may be required to submit additional bio-assay samples on an occasional basis, to ensure that applicable radionuclide exposure standards are being met.

3. It is the subcontractor's responsibility to ensure that each employee submits bioassay samples as required by the Subcontract.

4. The Contractor will notify the subcontractor of any employee who fails to provide a required bioassay sample. The communication will state that urine sample submittal to the contractor representative is a subcontract requirement. If the issue is not resolved, the Contractor's Subcontract Administrator will notify the subcontractor, by written communication, that the employee will be restricted from all radiologically controlled areas.

5. Employees who fail to provide a bioassay sample will not be permitted on the site, and will be disqualified as a radiation worker.

6. Employees disqualified as radiation workers must be retrained and qualified prior to any access to a radiological controlled area.

7. In the unlikely event that an employee has a confirmed positive bioassay result, he may be temporarily 
restricted from the controlled area for radiological evaluation.

8. The subcontractor shall notify the contractor of any personnel terminations or transfers as early as possible, but no later than two working days in advance of such terminations or transfers. This notification will allow sufficient time to collect a termination bioassay sample.

G. Warning signals: Certain circumstances such as unusual or unanticipated radiation levels, presence of toxic substances, or unsafe working conditions may prompt the contractor to give verbal information or directions, as Warning signals, directly to the subcontractor and his employees. The subcontractor and his employees shall take required actions as directed by the contractor or his representative. The subcontractor shall obtain the name and title of the contractor's representative providing such information.

H. Decontamination and Monitoring of Vehicles and Equipment:

1. All vehicles and equipment will be monitored for radioactive contamination prior to initial entry into a radiological controlled area.

2. Vehicles, equipment and tools that are to be removed from radiologically controlled areas (free release) shall be cleaned of all potentially contaminated soils and will be monitored for radioactive contamination by the contractor prior to removal from the area.

3. When vehicles are decontaminated for release from one radiologically controlled area to another (controlled release), they will be monitored for contamination by the contractor. The contractor will initially monitor 100 percent of the vehicles for contamination. As experience begins to indicate that the decontamination process is being performed adequately, the percentage of vehicles that are monitored may be reduced to as few as 10 percent. Monitoring may be increased as contamination levels increase.

4. Vehicle decontamination facilities will be provided as specified in Section 01500, Article 1.15.

5. During snowfall or icing conditions complete removal of snow or ice may be required for decontamination.

6. Equipment will normally be decontaminated prior to any maintenance other than routine servicing.

Document No. 3885-RFL-S-01-00729-04

Issued for Construction-Revision 1 Special Conditions 
I. Tailings Leakage in Uncontrolled Areas:

1. Leakage of tailings or contaminated materials will not be allowed in uncontrolled areas.

2. The Contractor will perform baseline surveys of all haul routes outside of controlled areas.

3. The contractor will periodically monitor the haul route and compare the data against baseline to detect spills of contaminated material. The subcontractor shall clean up any contaminated material leaked or spilled outside of the controlled area, and the area shall be restored as required by the contractor.

J. Disposition of Contaminated Equipment, Tools and Material:

1. The subcontractor shall use his own or rental equipment in performing the required work under this subcontract. All tools, vehicles, equipment and material will be inspected for radioactive contamination by the site Manager or his designee prior to removal from the construction area.

2. Should the subcontractor's tools, material, or equipment become contaminated, they will have to be decontaminated before removal from the area. If decontamination becomes necessary, the site Manager will provide instructions for decontamination by the subcontractor's employees. Decontamination may consist of steam cleaning, dry brushing, or washing with appropriate liquids. Decontamination required beyond these described will be handled under Article GP-52, "CHANGES" of the General provisions. All releases shall be on an ALARA basis as determined by the contractor.

3. If decontamination proves impracticable or impossible, the tools, material, or equipment in question will be retained by the contractor and an equitable adjustment for same will be negotiated with the subcontractor provided that:

a. There is no fault or negligence of the subcontractor contributing to the contamination.

b. The subcontractor has followed all the specific instructions of the authorized HP personnel who have surveillance over the work.

c. Items or equipment confiscated from the subcontractor will be documented by a Confiscation Notice

Document No. 3885-RFL-S-01-00729-04

Issued for Construction-Revision 1

Special Conditions

5400 S/WP 51

RFL-PH-II

$00800-30$

121991 
furnished to the subcontractor by the contractor and signed by HP personnel and the site Manager.

d. The subcontractor allows reasonable time (a minimum of ten (10) working days, excluding weekends and holidays) in which to attempt decontamination of the item(s) in question. The reimbursement schedule will be as follows:

1) Tools valued less than $\$ 300.00$ at $95 \%$ of replacement cost.

2) Tools/Equipment $\$ 300.00$ and up: If less than one (1) year old or at top of depreciation schedule, at $75 \%$ of replacement cost; if at bottom of or off the depreciation schedule, at $50 \%$ of replacement cost.

e. Failure to agree upon equitable adjustment shall constitute a dispute within the meaning of Article GP-41 of the General Provisions.

f. In view of the foregoing, the subcontractor is encouraged to plan his work so as to minimize the transfer of equipment into and out of the construction area.j*

SC-9 SUBMITTALS

Pursuant to the provisions of specification Section 01300 Submittals, the subcontractor shall submit samples of materials, schedules and reports, shop drawings, product data, manufacturer's instructions, and design calculations and design drawings to the contractor.

\section{SC-10 QUALITY ASSURANCE}

All work shall be performed to the requirements of the Contractor's Quality Assurance Program. This program meets the applicable requirements of 10 CFR 50 Appendix $B$ and ANSI/ASME NQA-1-79. The program will be wholly administered by the Contractor for permanent record purposes. All Quality Records will be generated by and maintained by Contractor's personnel.

$\star$ P.I.D. $06-5-17$ 


\section{SC-11 PERMITS}

A. The contractor will provide the following permits and notifications as required, for the facilities and activities depicted on the subcontract Drawings, except as noted below in Article SC-11.B:

1. Dredge and Fill Permit - for Processing site and Disposal site (U.S. Army Corps of Engineers)

2. Threatened or Endangered Species Consultation (U.S. Fish and Wildife service)

3. Cultural Resource clearance - for Processing and Disposal Sites and Estes Gulch Access Road (Colorado Historic Preservation office and U.S. Bureau of Land Management)

4. Air Pollutant Emissions Notice and Emission Permit - for earthmoving activities (Colorado Department of Health, Air Pollution Control Division)

5. State Highway Access Approach Permit - for Estes Gulch access

[(Colorado Department of Transportation)]*

6. Utility Permit - excavation within highway $\mathrm{R}-\mathrm{O}-\mathrm{W}$ [(Colorado Department of Transportation)]*

7. Colorado Pollutant Discharge system Permits - for discharge of wastewater from retention basins or treatment facilities

(Colorado Department of Health, Water Quality Control Division)

8. Right-of-Way and Temporary Use Permit - for Estes Gulch site access road and construction area at disposal site (U.S. Bureau of Land Management)

9. Access into Railroad Right-of-Way - for contaminated material cleanup, and backfill and construction of slurry wall

(Denver and Rio Grande Western Railroad)

* P.I.D. 06-S-17

Document No. 3885-RFL-S-01-00729-04

Issued for Construction-Revision 1

Special conditions 
10. Certificate of Designation for Solid Waste Disposal Site - for Estes Gulch Disposal Site

(Garfield County Board of Commissioners and colorado Department of Health)

11. Conditional Use Permit - for Estes Gulch Disposal Site (Garfield County Board of Commissioners)

12. Water Rights - for retention basins at Disposal and Processing Site

(Colorado Division of Water Resources and District Water court)

B. All other permits and notifications, including but not limited to the following, shall be the responsibility of the Subcontractor in accordance with Article GP-47 of the General Provisions. The subcontractor shall provide copies of all other permits and notifications to the contractor.

1. Approval of Road Construction - for improvements to haul road

[(Garfield County, Bureau of Land Management, and Colorado Department of Transportation) ]*

2. Permit to Construct a Well - for water supply and/or monitor wells if required

(Colorado Division of Water Resources)

3. Well Abandonment Affidavits - for all wells that are abandoned

(Colorado Division of Water Resources)

4. Spill Prevention Control and Countermeasures Plan - for on-site fuel/oil storage as required

(U.S. Environmental Protection Agency and colorado Department of Health)

5. Emission Permit for Gasoline Storage Tanks (Colorado Department of Health, Air Pollution Concrol Division)

6. Open Burning Permit - for uncontaminated materials only (Colorado Department of Health, Air Pollution Control Division)

7. Building Permit - for trailer pads

(Garfield County Planning Department)

P.I.D. 06-S-17 
8. Mobile Home siting Permit - for office trailers (Garfield County Planning Department)

9. Water Rights - for new water supply wells or surface water withdrawals, if required

(Colorado Division of Water Resources and District Water Court)

10. Approval of Disposal of Nonhazardous Wastes - for disposal of uncontaminated construction debris

(Garfield county Board of Commissioners for certificate of Designation)

11. For existing or privately owned borrow pits/quarries, including those shown on the subcontract Drawings, Subcontractor shall verify that the owner/operator has all permits and clearances necessary to operate these facilities. If subcontractor elects to develop borrow areas other than those shown on the subcontract Drawings, he shall obtain all permits required to operate and to obtain access to those areas including, but not limited to, the following, as required:

a. Mining and Reclamation Permit

(Colorado Mined Land Reclamation Division)

b. Air Pollutant Emissions Notice and Permit (Colorado Department of Health, Air Pollution Control Division)

c. Land Use Permit (County Planning Department)

d. Electrical permits as required.

e. Cultural Resource clearance (Colorado Historic Preservation office and appropriate federal land management agency, if on federal lands)

f. Threatened and Endangered Species Consultation (U.S. Fish and Wildlife Service)

12. Asbestos Removal/Demolition Permit [ (Colorado Department of Health, Air Pollution Control Division) ]*

เP.I.D. 06-S-17

Document No. 3885-RFL-S-01-00729-04

Issued for Construction-Revision 1

Special Conditions 
c. The subcontractor shall comply with the provisions of the permits at all times during the execution of the subcontract. The contractor will make available to the Bidders the permits and their provisions for review by the Bidders.

D. Separate measurement or payment will not be made for work required of the subcontractor for obtaining additional permits and for compliance with the provisions of all permits, unless specifically provided for in this subcontract. All costs in connection with obtaining such permits and for compliance with such permits will be considesed incidental to the subcontract.

\section{[SC-12 SUBCONTRACTOR LABOR AND EOUIPMENT RATES}

A. Within 30 days after receipt of Notice to Proceed, the Subcontractor shall furnish to the contractor a list of all equipment to be used on the Project. The list, as a minimum, shall include the following for each piece of equipment:

1. Equipment number, make, model, type, year of manufacture, capacity and/or horsepower, attachments, and any other information necessary to determine applicable Rental Rate Blue Book for Construction Equipment rates. Attachments, if any shall be reasonable and necessary for the work intended on the job or not be included when calculating appropriate rates.

2. Hourly rental rate calculated at the Subcontractor's normal rate for each piece of equipment, not to exceed 60 percent of the monthly rate, divided by 176, from the current edition of the Rental Rate Blue Book for Construction Equipment.

3. An hourly operating rate for fuel, oil, parts, maintenance and repairs, etc. for actual hours of operation only. This rate shall be not more than 100 percent of the operating rate from the current edition of the Rental Rate Blue Book for Construction Equipment.

4. When standby of equipment is required, the standby rate shall be hourly rental rate calculated at 60 percent of the monthly rate, divided by 176, from the current edition of the Rental Rate Blue Book for Construction Equipment. Maximum standby time allowed shall be for 8 hours in any day, 40 hours in any week, or 176 hours in any month. 
5. All equipment rates shall be inclusive of subcontractor markups.

B. The above rate information shall also be provided for any subseguent equipment brought onto the site during the term of the subcontract in addition to the initial list, and shall be provided within five days of the date the equipment arrives.

c. The initial equipment rate list submittal, with additions, shall be valid for all pieces of equipment from its receipt until January 1 of the following year.

D. The equipment rate list shall be revised on January 1 of each year with the current Blue Book rates. These rates shall be used until the equipment rate list is revised on January 1 of the following year.

E. The Subcontractor shall maintain and submit records annually to the Contractor of fuel taxes and vehicle fees paid to the state of Colorado for all construction equipment and vehicles used on the project.

F. Within 30 days after receipt of Notice to Proceed, the subcontractor shall furnish to the contractor labor rates including premium time for all craft designations to be used on the project as follows:

1. List craft category and classification (i.e., loader operator, 6 cy; truck driver, 3 axle; etc.). The category and classification should be consistent with the Davis-Bacon wage determination for the Project.

2. Labor cost rates including fringe benefits, payroll, taxes, and insurance.

3. Each item in 1 and 2 above shall be listed separately.

The above labor rate information shall be revised and resubmitted on January 1 of each year with current payroll burden rates.

The above labor rates shall be exclusive of subcontractor overhead and profit.

G. The rates provided in Paragraphs A through $\mathrm{E}$ above shall be used for changes to the subcontract where unit prices or other methods of pricing do not apply and shall be used solely at the discretion of the Subcontract Administrator.]*

* P.I.D. 06-S-17

Document No. 3885-RFL-S-01-00729-04

Issued for Construction-Revision 1

Special Conditions

5400 S/WP51

RFL-PH-II

$00800-36$

121991 
The subcontractor, in connection with any proposal he makes for a subcontract change Notice, shall furnish a price breakdown, itemized as required by the subcontract Administrator. Unless otherwise directed, the breakdown shall include all estimated labor and equipment hours, and associated costs, materials, subcontracts, and overhead and profit required to permit an analysis, and shall cover all work involved in the change notice, whether such work was deleted, added or changed. Any amount claimed for subtiersubcontractors shall be supported by a similar price breakdown and/or quotes from the subtier-subcontractors. In addition, if the proposal includes a time extension, a justification therefor shall be furnished. The proposal, together with the price breakdown and time extension justification, shall be furnished to the subcontract Administrator within thirty (30) calendar days after receipt of the Change Notice.

\section{SC-14 VARIATIONS IN OUANTITIES}

In all cases, except cancellation of one or more line items, where the quantity of a unit priced line item in the subcontract is an estimated quantity, and where the actual quantity of such line item varies by more than $10 \%$ above or $10 \%$ below the originally estimated quantity stated in the subcontract, an adjustment in unit price shall be negotiated upon demand of either party for the quantities above or below the stated variation.

\section{SC-15 LAWS AND REGULATIONS}

Subcontractor shall give all notices and comply with all laws, ordinances, rules and regulations applicable to the Work. If subcontractor observes that the specifications or subcontract Drawings are at variance therewith, subcontractor shall give contractor prompt written notice thereof, and any necessary changes shall be adjusted by an appropriate Modification. If subcontractor performs any Work knowing or having reason to know that it is contrary to such laws, ordinances, rules and regulations, and without such notice to Contractor, subcontractor shall bear all costs arising therefrom; nowever, it shall not be subcontractor's primary responsibility to make certain that the specifications and subcontract Drawings are in accordance with such laws, ordinances, rules and regulations. 
A. Of the total subcontract Price, the sum of $\$$

is presently available for payment to the subcontractor under this subcontract during this current fiscal year. It is anticipated that additional funds will be allotted from time to time to this subcontract subject to Government appropriations available in this fiscal year or succeeding fiscal years. The responsibilities of contractor are limited by this clause notwithstanding any contrary provision of the "Payments to subcontractors" clause or any other clause of this subcontract.

B. The subcontractor agrees to perform or have performed work up to the point at which, in the event of termination of this subcontract pursuant to the clause hereof entitled "Termination for convenience", the total amount payable by the Contractor (including amounts payable in respect of lower-tier subcontracts and settlement costs), pursuant to paragraph $\mathbf{E}$ thereof, would in the exercise of reasonable judgment by the subcontractor approximate the total amount at the time allotted to this subcontract. The contractor shall not be obligated in any event to pay or reimburse the subcontractor in excess of the amount from time to time allotted to this subcontract, anything to the contrary in this clause or the clauses hereof entitled "Termination for Convenience" as specified in Article GP-55 and "Payments to subcontractors" as specified in Article GP-38 of the General Provisions notwithstanding.

C. It is contemplated that funds presently allotted to this subcontract will cover the work to be performed until In the event funds allotted are considered by the subcontractor to be inadequate to cover the work to be performed until the above date, the subcontractor shall notify the subcontract Administrator when the work will reach a point at which, in the event of termination of this subcontract pursuant to the clause hereof entitled "Termination for Convenience", the total amount payable by the contractor (including amounts payable in respect of lower-tier subcontracts and settlement costs) pursuant to Paragraph E thereof, will approximate $85 \%$ of the total amount then allotted to this subcontract. such notice shall be in writing and shall be given not less than 45 days nor more than 60 days prior to the estimated date when such point will be reached. Such notice shall also state the estimated amount of additional funds required to continue performance to the above stated date. The subcontractor shall, 30 days prior to the date above stated, advise the subcontract Administrator in writing as to the estimated amount of additional funds

Document No. 3885-RFL-S-01-00729-04

Issued for Construction-Revision 1 Special conditions 
which will be required for the timely performance of this subcontract for the balance of the current fiscal year and the succeeding fiscal year. If after a period of 60 days after such latter notification, additional funds are not allotted, the subcontractor, by written notice delivered to the subcontract Administrator at any time before such additional funds are allotted, may elect to treat its responsibility to proceed with the work under this subcontract as having been terminated. Such a termination shall be considered a termination pursuant to the clause hereof entitled "Termination for convenience".

D. The Contractor may at any time prior to the subcontractor's election to terminate as provided in Paragraph $c$ above, and with the written consent of the subcontractor after such election to terminate, allot additional funds for continued performance of this subcontract. The subcontract Administrator will promptly notify the subcontractor in writing, of any such allotment and the parties shall: (a) agree on the applicable period of subcontract performance which shall be covered by such funding; (b) modify the date stated in Paragraph $C$ above in order to reflect such extended period of coverage; and (c) modify the amount stated in Paragraph $A$ above. The provisions of Paragraphs $B$ and $C$, above, shall apply to such additional allotted funds and modified date.

E. In the event the subcontractor incurs additional costs, or is delayed in the performance of the work under this subcontract, solely by reason of the failure of the contractor to allot additional funds pursuant to Paragraph D above in the amounts sufficient for the timely performance of this subcontract, and if additional funds are allotted by the Contractor pursuant to Paragraph $D$ for continued performance of this subcontract, then an equitable adjustment may be made in the subcontract Price (including appropriate target, billing and ceiling prices where applicable) or in the time required for the performance of the work, or both, and this subcontract may be modified in writing accordingly; provided, that the subcontractor provides to the subcontract Administrator written notice of its claim of entitlement to an equitable adjustment prior to the date then stated in Paragraph $\mathrm{C}$.

F. Nothing in this clause shall affect the right of the contractor to terminate this subcontract pursuant to the clause of this subcontract entitled "Termination for Convenience".

Document No. 3885-RFL-S-01-00729-04

Issued for Construction-Revision 1 Special Conditions 
In addition to the copies of certified payrolls that are to be submitted each week to the Subcontract Administrator, one copy will also be submitted to the site Manager.

SC-18 SUBCONTRACTOR'S IIABIIITY

The subcontractor has total liability for all of his own equipment, supplies, tools, etc., brought on the job site or used in the performance of his subcontract.

\section{SC-19 COLORADO SALES AND USE TAX}

[A. The Subcontractor shall submit the enclosed Subcontractor information sheet with the required information for their company and any lower-tier subcontractor. Subcontractors listed on the subcontractor Information sheet will be provided exemption certificates upon approval of the application by the contractor. The above information shall be provided to the Contractor for any subsequent lower-tier subcontractors utilized during the course of this subcontract.

B. Upon obtaining a certificate from the Colorado Department of Revenue, the subcontractor shall be exempt from state and local sales and use tax on the purchase of construction materials for use in the building, erection, alteration, or repair of structures, highways, roads, streets, and other public works owned and used by the United States Government, the State of colorado, its departments and institutions, and its political subdivisions in their governmental capacities only.

c. The City of Denver imposes a 3 percent sales or use tax, but allows an exemption from the tax for goods delivered outside the city limits by common carrier or the vendor's vehicles.

D. The City of Denver does not exempt materials purchased by a subcontractor for use in a job for an exempt institution.

E. Consumable supplies used in the performance of the subcontract and not becoming part of the permanent construction project will be taxable to the subcontractor.]*

*P.I.D. 06-S-17 
F. Lower-tier subcontractors who furnish and install permanent materials shall obtain their own exemption certificates for the purchase of materials.

SC-20 MEASUREMENT AND PAYMENT

A. Unless otherwise provided in the subcontract Documents, no separate measurement or payment will be made for compliance with the provisions of the General provisions, General Conditions and special conditions. Full compensation for such work will be considered to be included in the related items of Bid Schedule or incidental to the subcontract.

B. Payment for the cost of premiums paid by the subcontractor to obtain performance and payment bonds will be as specified in Article GP-38.E of the General Provisions. The Subcontractor shall quote the price for the premiums by the lump sum in the Bid Schedule. (Bid Schedule Item 002)

SC-21 LIMITATIONS ON SUBCONTRACTING

A. By submission of an offer and execution of a subcontract, the subcontractor agrees that in the performance of the subcontract:

1. For general construction, the subcontractor shall perform at least 60 percent of the cost of the subcontract, not including the cost of materials, with its own employees.

B. Any deviation from the above limitations on subcontracting requirements will require prior approval of the contractor.

SC-22 BULLETIN BOARDS

Bulletin boards with all required bulletins and all other displayed items shall be located in the Access control Trailer.

[SC-23 CONTAMINATED MATERIALS HAUL INSURANCE REOUIREMENTS

The subcontractor shall provide the contractor evidence of insurance (additional bonding will not be accepted) as required by 49 CFR 387, Minimum Levels of Financial Responsibility For Motor Carriers. This requirement is in addition to those limits required by General Condition $(G C-7)$. All other conditions contained within GC-7 shall 
also apply to this additional insurance. It shall be the Subcontractor's responsibility to obtain a determination from the U.S. Department of Transportation as to the definition of a hopper-type vehicle. A copy of this determination shall be submitted to the contractor along with the evidence of insurance as well as a description of the type of vehicle the subcontractor will use.]*

END OF SECTION 00800

* P.I.D. 06-S-17

Document No. 3885-RFL-S-01-00729-04

Issued for Construction-Revision 1

Special conditions 
Suncontnetors listed below will be awerded exemptlon cortificates upon approval of your applicaflon. Only those subcontractors who purchase construction or bullding materials for Inclusion in the exempt project should be llsted. Those subcontractors who piovide service only should not be included.

SUBCONTRACTOR INFORMATION

(Additional sheets may be attached if necessary)

\begin{tabular}{|c|c|c|}
\hline \multirow[t]{3}{*}{ Name \& Address of Subcomiractor. } & Name of contact pereon: & Business phone number. \\
\hline & Amoumt of subcontract: & Colorado withholding account number: \\
\hline & \multicolumn{2}{|l|}{ Type of construction: } \\
\hline \multirow[t]{3}{*}{ Name \& Address of Subcontractor. } & Name of contact person: & Business phone number. \\
\hline & Amoumt of subcontract: & Colorado withholding account number: \\
\hline & \multicolumn{2}{|l|}{ Type of construction: } \\
\hline \multirow[t]{3}{*}{ Name \& Address of Subcomtractor. } & Name of contact person: & Business phone number. \\
\hline & Amoum of subcontract: & Colorado withholding account number: \\
\hline & \multicolumn{2}{|l|}{ Type of construction: } \\
\hline \multirow[t]{3}{*}{ Name \& Address of Subcontractor. } & Name of comtact person: & Businese phone number. \\
\hline & Amoum of subcontract: & Colorado withholding account number: \\
\hline & \multicolumn{2}{|l|}{ Type of construction: } \\
\hline \multirow[t]{3}{*}{ Name \& Address of Subcontractor. } & Name of comlact person: & Business phone number: \\
\hline & Amoum of subcontract: & Colorado withholding account number: \\
\hline & \multicolumn{2}{|l|}{ Type of construction: } \\
\hline \multirow[t]{3}{*}{ Name \& Address of Subcontractor: } & Name of comtact person: & Business phone number: \\
\hline & Amoum of subcontract: & Colorado withholding account number: \\
\hline & \multicolumn{2}{|l|}{ Type of construction: } \\
\hline \multirow[t]{3}{*}{ Name \& Addrees of Subcomtractor. } & Name of contact person: & Business phone number: \\
\hline & Amoum of subcontract: & Colorado withholding account number: \\
\hline & \multicolumn{2}{|l|}{ Type of construction: } \\
\hline \multirow[t]{3}{*}{ Name \& Address of Subcontractor. } & Name of comtact pereon: & Business phone number. \\
\hline & Amoumt of subcontract: & Colorado withholding account number: \\
\hline & \multicolumn{2}{|l|}{ Type of construction: } \\
\hline
\end{tabular}




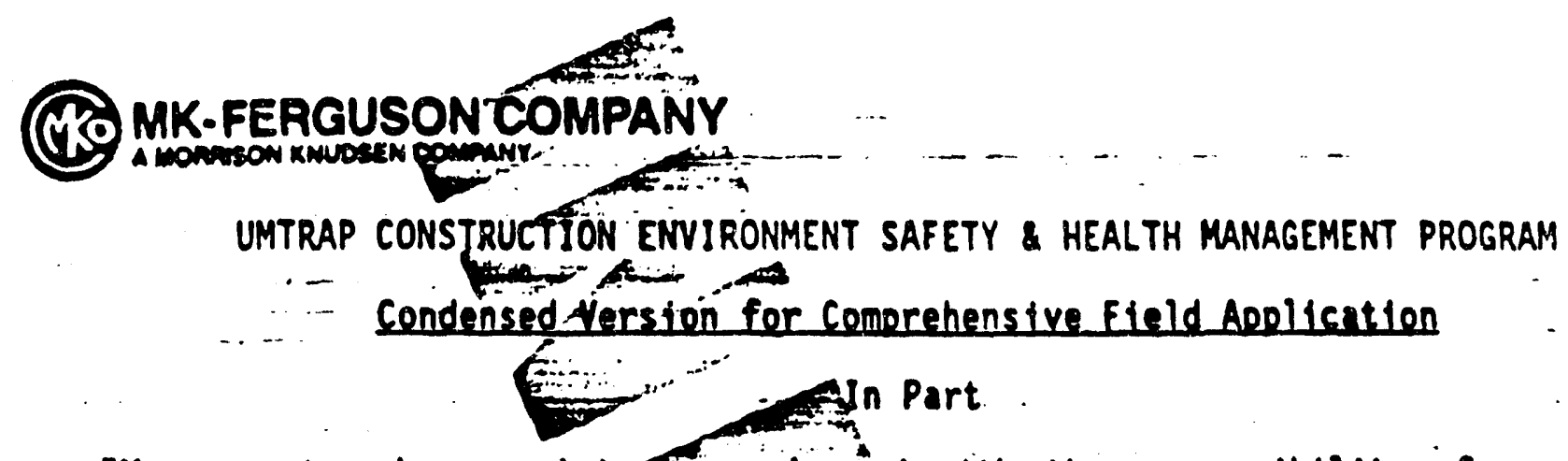

- Management and supervisjon are charged with the responsiblitity of preventing the occurrence of incfdents or: conditions that could lead to occupational injuries or iliness. WhHe the ultimate success of a safety and health program depends upon the full cooperation-of each individual employee, it is management's responsibility to see that safety and health rules and procedures are adequate and enforced, and to see that effective training and education programs are employed to the best advantage."

- Never should safety be sacrificed for production. It must be considered an integral part of quality control, cost-reduction and job efficiency. Every supervisor will be held accountable for the safety performance demonstrated by the employees under his superviston.".

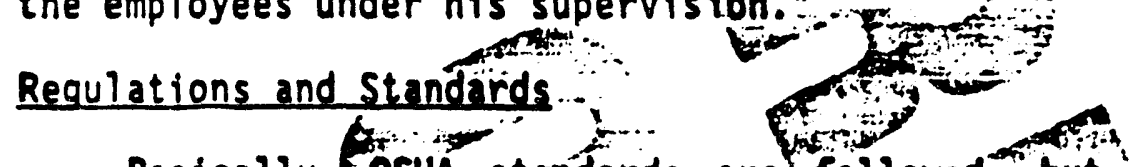

Basically, OSHA standards are followed, but we also comply with local, state, and applicable federal standards. Reference: Page $v i$ in the Construction Environment Safety and Health Management Program.

\section{Purpose}
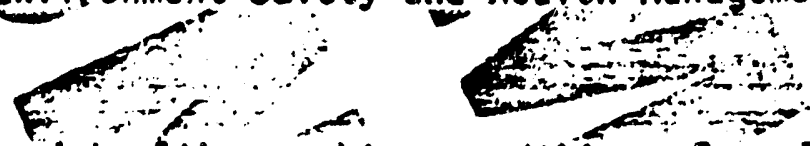

Provide safe and healthy working conditions for all RAC and subcontractor employees while protecting the general public. Reference: Page 1 in the Construction Safety and Health Management Program::

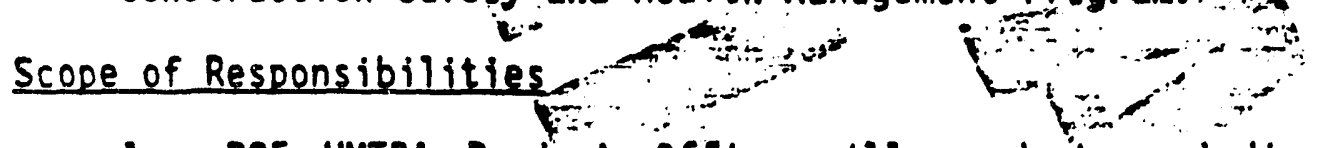

1. DOE UMTRA Project Office will conduct periodic safety and heaith audits of remedial action contractors

2. Technical Assistance Contractor will prepare, health and safety survey reports.

3. Remedial action contractor will, under the guidance of the Project Director, provide a management overview for alf safety' and health requirements, ensure adherence to the mañagement program, and participation by all supervision.

4. All remedial action subcontractors shall complyith all applicable local, state, DOE/UMTRA and federal safety and health codes, regulations, standards, and spectal procedures. The remedial action contractor's Construction Environment 'safety ind . Health Management Program shall be an integral part of the subcontract, including mandatory implementation and compliance by the various remedial action subcontractors. Reference: Page $6-$ in the Construction Environment Safety and Health Management Program: 
1. The RAC Safety fepartinent personnel or designated representative will make regular Anspections of all facllities and operations within the scope of the contract. These inspections will include the facilities and operations of all subcontractors, but do not, in any way, rel ieve subcontractors of their. responsibility for compliance with the provisions of his program

2. Daily work area safity health inspections will be made by RAC personnel and subcontractór supervision.

3. Fallure of the remedial action subcontractor to comply with the established safety regulations" and procedures and/or conducting activities which are considered. unsafe by the remedial action contractor or the Department of Energy shall constitute cause of stoppage of work in accordance with Article GP-35, "Safety and Health" of the General Provisjons. Reference: Page 8 in the Construction Environment Safety and Healthi Management Program.

Audits

1. MK-F Corporate safety staff will conduct audits quarterly or as needed based in scheduled work act fivity.

2. DOE UMTRA Project Office wijh conduct periodic safety and health audits of femedial action subcontractors.

3. RAC will conduct informal and formal audits.

Reference: Sage $g$ in-the Construction Environment Safety and Health Management Program.

Fire Prevention and Protettion
1. All remedial act ton contractôr and subcontractor elpolo

positive positive measures to prevent fires within their work areas on the site. There will be mith some cases, work sities that have established fire departments nGarby for-response in case of fire. In these Instances, the phone inumber of the fire department wili-be posted and notified immediately in case of fire. Notification shaill also be made to the on-site remedial action contractor management personnel. The on-site management shall immediately notjfy, the Project Safety Department in Albuquerque, New Mexico.

2. If the fire results in property damage, not ffication to the RAC, reporting extent and estimated cost shall be made. An investigation shall be conducted to determine cause with faretual. Information gathered for a formal report to DOE/UMTRA Remedtal Action-Project Office by the remedial action contractor.

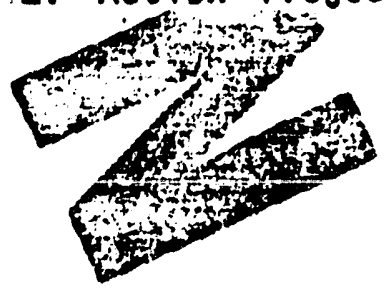




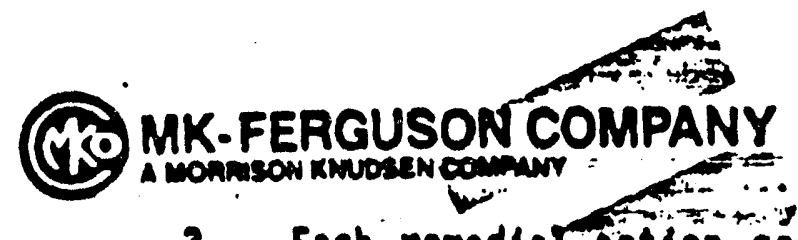

3. Each remediar action contractor shall maintain a fire prevention and control effort approprlate for the needs of the site. In some cases there may be sufficient cause to requite a trained. fire brigade-- Each remedial action subcontractor shall provide proper fire extinguishers, maintain the and train employees on how they are to be used.

Reference: Page 10 in the Construction Environment Safety and Health Managenient Programio on

\section{Eirst Aid and Medical}

1. The subcontractor shar provide or arrange for adequate facilities and qualified personnel to ensure prompt and efficient first aid medical care and emergency transportation of injured or sick employees.

2. Advance arrangements to utilize nearby hospitals, clinics, local ambulance services, or other medical facilities and the services of professional medical personnel must. be made prior to commencement of work. These arrangements. Will be made by the RAC Construction Safety and Heaith Management.

$$
\text { alth Management. }
$$

3. Each shift must tiave at least one-supervisor holding a current first ald certificate.

4. All project management is encouraged to have every foreman or supervisor qualified for first ald certificates.

$$
\text { quat? }
$$

5. When required, as specified in.-the special conditions, a standby automotive unit shall be provided for ambulance service. This unit should be properly equipped to accommodate a stretcher and allow for prompt, comfortable transportation of personnel to medical or hospital facilities.<smiles>C#CCCCCCCCCCCCC</smiles>

6. The emergency telephone numbers, for the local hospitals, ambulances, fire and police departments must be conspicuously posted around the job site on the orange colored postersivalilable through the Safety Department of the remedial action contractor. Reference: Page 13 in the construction Environment Safety and Health
Management Program.

Records. Reports and Postings

1. Remedial action contractor field records:

a) Safety inspections (MK-F Form CAS-21).

b) Employee complaints and response action.

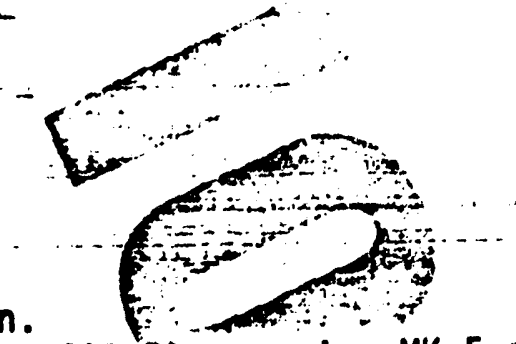

c) Daily First Aid Treatment $\log$ (MK-F Form CAS-8) covering MK-F and CNSI personnel.

d) Copies of all subcontract Dafly First Aid Treatment logs.

e) Transmit a copy of all the above to RAC Safety Department, Albuquerque.

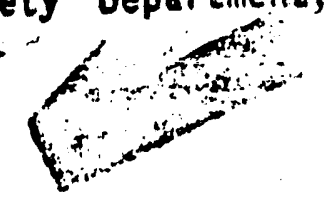




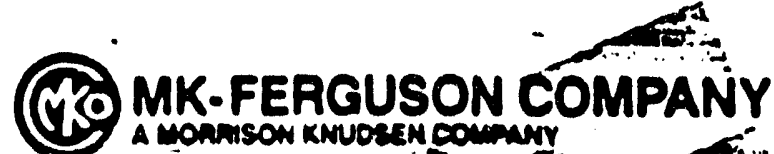

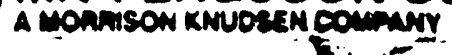

2. Remedtat-action subcontractor records:

a) Daffy First Aid Treatment $\log$ (MK-F Form CAS-8) with the original

bent to the RAC Safety Department, Albuquerque.

b) Log of Occupational Injuries and IIInesses (OSHA Form No. 200)

3. Remedial action subcontractor reports:

a) Supervisors Accident Investigation Report (MK-F Form CAS-24)

b) Unusual Occurrence Report

c) Report employee complaints with corrective action.

d) Report all recordable accidents (those not first aid).

4. Remedial action subcontractör reports:

a) Report all recordable accidents (those not first aid).

b) Unusual Occurrence Report.

c) Supervisors Accident Investigation Report (MK-F Form CAS-24)

d) Employee's first ireport of injury to insurance carrier and Remedial Action Contractor Safety Department, Albuquerque.

5. Remedíal action contractor and subcontractors:

a) DSHA and DOE "Occupational Safety and Health Protection" posters. (OSHA Form No: 2203 and DOE-F-5480.2,-formerly DOE Forin EV-627).

b) Emergency poster (MK-F Form CAS-22)

c) OSHA Log Form No. 200. Summary will be posted for 30 days following, the calendar year end between February 1 and March 12, at the work site.

Reference: Page 17 in the Construction Environment Safety and Health Management Program.

\section{Emergency Action}

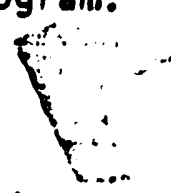

1. Categories with potential emergency action are:

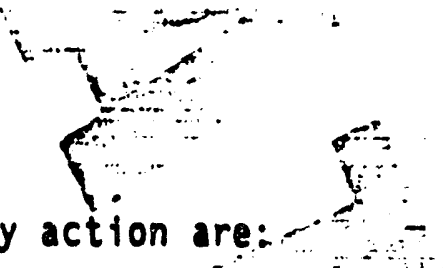

a) Accident with serious bodily injury or major equipment damage.

b) Severe weather. $i$."

c) Fire.

d) Contaminated materials

sp.ill in th

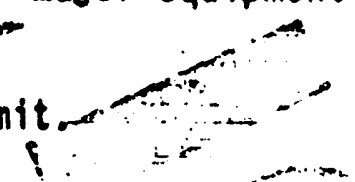

The Site Manager and Radiation Safety Officer control emergency action by giving direction as needed. Alternate individuals must be preassigned to fulfill the responsibility for control in case key personnel are absent during emergency action.

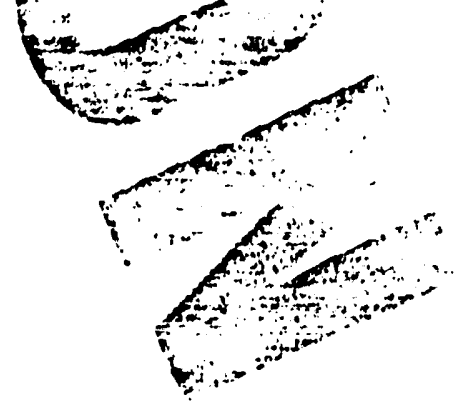




\section{(19.MK.FERGUSON CO MPANY

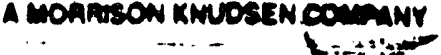

2. The RAC Canstruction Safety and Health Manager will preplan and coordinate with local emergency and medical facilities for potential assistance. in afr categories.

3. Each site witi have a plan-with specific assignments for response to a truck spillit

4. Site Managers Shâli not ffy. RAC, Albuquerque with all pertinent information fomediately. Response, if necessary, and further notifications that are appropriate or required, will then proceed by responsible personnel in Albuquerque.

Reference: Page 30 in the Construction Environment Safety and Health Management Program.

Safety and Health Training Program

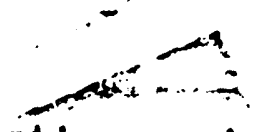

1. The purpose for implementing a training program is to provide instruction to each employee to include the recognition and avoidance of unsafe acts and conditions applicable to the work environment. I It is also designed to assist subcontractor supervision in instructing each employee to recognize regulations established to control or el iminate hazards or other exposure to iliness or injury.

$$
\text { dits }
$$

2. Construction safety and health training is an inherent responsibility of direct line supervision. Management for the remedial action contractor - ind the subcontractor, -must monitor line supervisors' training activitles to ensure compliance with the purpose of training.

3. Each employee shall be given an initial indoctrination by a remedial action contractor designated person at-the work site. It may be oral or written and must take place before the employee may start work on the site.

4. The subcontractor supervisor or foremen ins inst

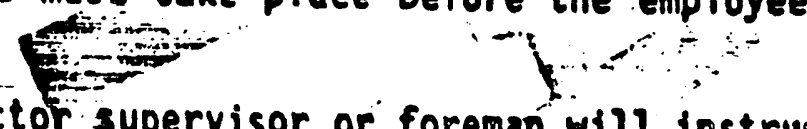

foreman will instruct each worker in a will be equipment which worker will work, and the penaled, the safety rules, under which the will also be explained penaities for fallure to observe these rules requirements ench employee will be advised of the requirements for fire protection and special precautions to be taken if the work requires the use of flamable liquids, toxic materials, or other harmful substances. The electrical hazards, if any, will be emphasized.

5. Neekly safety training meetings shall be conducted by RAC and subcontractor supervisors or foremen. Attendance is mandatory for all employees at the work site. A record of these meetings shall be maintained on MK-F Form CAS-11 for RAC and subcontractors.:. The original form must be iransmitted to the RAC Safety, Department in Albuquerque.

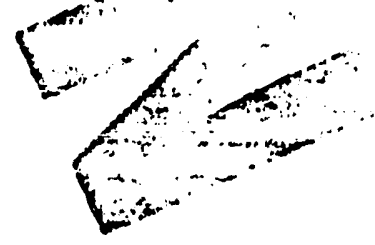


6. Each person expected to work 40 hours over a three-month period in an access controlled area will be required to complete an approved radiation worker training program. It consists of a two hour lecture discussion and a two hour practical applications demonstration.

Reference: Page-32 in the const
Management Program -
cal Control and Montitoring (CNSU)

$\frac{\text { Radiological Control and Monttorine (CNSI) }}{\text { A separate document by CNSI witl cover this topic. }}$

Environmental Control and Monfitoring (Industrial Hvaiene)

Noise - Ionizing Radiation : Nonionizing Radiation - Extreme Pressure Extreme Temperature - Gases, Vapors, Fumes, Dusts and Mists - Solvents Occupational Illinesses.

All of the above may, at one time or another, exist on this project. Our collective efforts to identify these before potential exposure becomes a reality must be a constant priority. For most categories, it requires methods for detection and evaluating the hazards. Very soon the instruments needed for measuring and evaluation will be obtained. The RAC Construction Safety and Health-Manager "will perform these measuring functions and will bring others in, when needed, for assistance to comply with local, state, and federal standards.

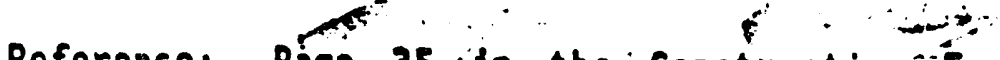

Reference: Page 35 in the Construction Environment Safety and Health Management Program.

\section{Access Control (NSI)}

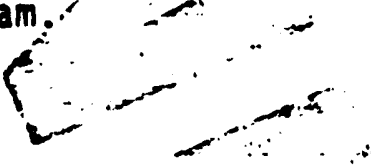

A separate document by CNSI will cover this topic.
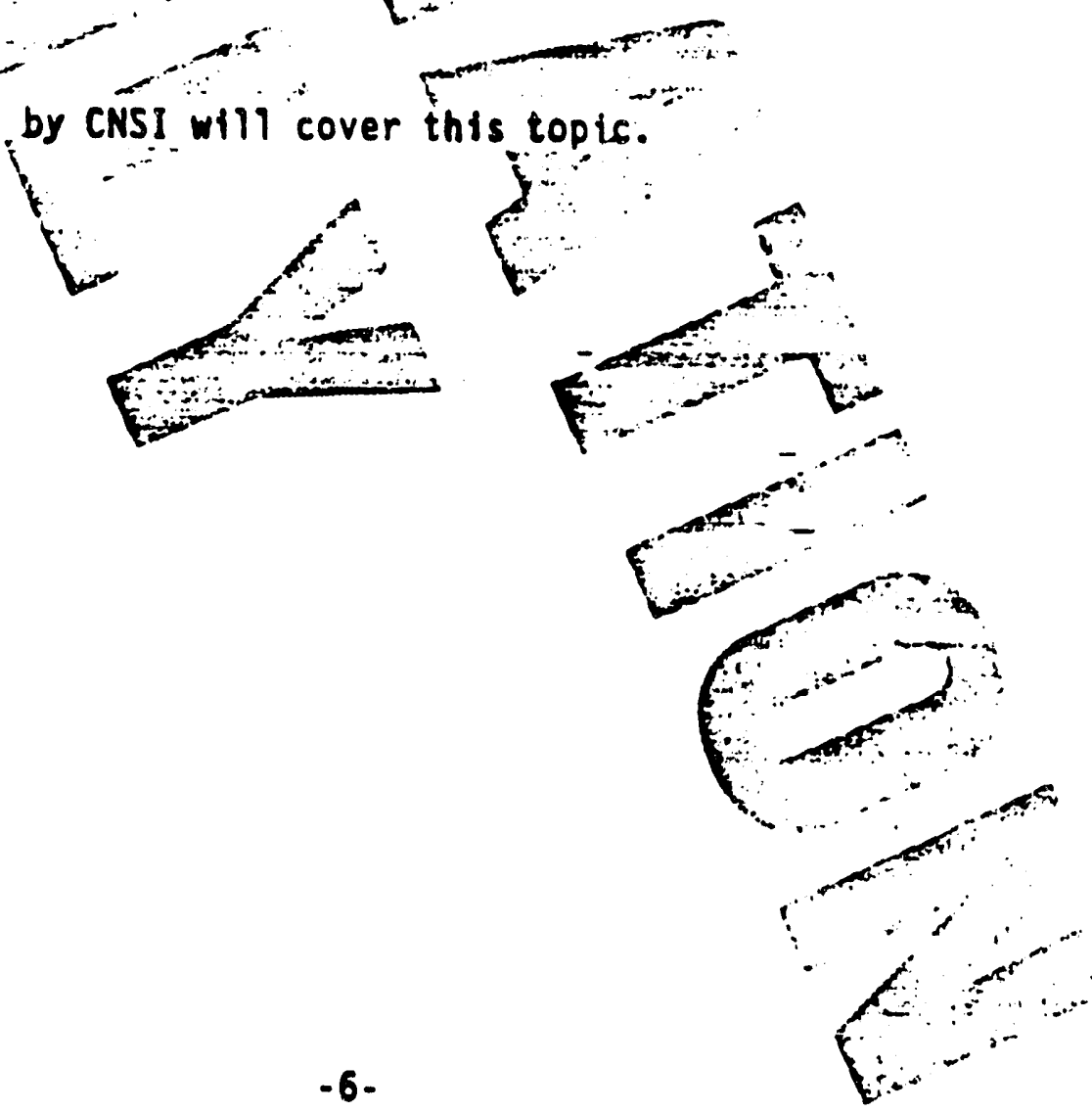
Specifications 


\section{Division 1 \\ General Requirements}


SECTION 01010

SUMMARY OF WORK

PART 1 - GENERAL

\subsection{DESCRIPTION OF THE PROJECT}

A. General: The work under this subcontract involves three sites: Old Rifle Processing Site, New Rifle Processing Site and Estes Gulch Disposal Site. The two processing sites are near the town of Rifle, Garfield County, West Central Colorado, and the Estes Gulch Disposal Site is approximately six miles north of Rifle.

B. Project Location:

1. Old Rifle Processing Site:

a. The old Rifle Processing site (also referred to in the Subcontract Documents as the old Rifle site) is located to the southeast of the town of Rifle right off U.S. Highway 6 and less than a mile from the center of Rifle. The 22-acre site has the U.S. Highway 6 as its north boundary and the Denver and Rio Grande Western Railroad as its south boundary. The Colorado River and Interstate 70 are immediately to the south of the Denver and Rio Grande Western (D\&RGW) Railroad. The site is located in sections 15-16, T6S, R93W, 6th PM, Garfield County.

b. Included within the 22-acre site is a 13-acre pile consisting of contaminated residual radioactive uranium mill tailings from the abandoned uranium mill site. This is located on the western half of the site. There is also a 9-acre mill area on the eastern half of the site which included the former ore storage and milling facilities.

2. New Rifle Processing Site:

a. The New Rifle Processing site (also referred to in the Subcontract Documents as the New Rifle site) is located to the west of the town of Rifle and is approximately two miles from the center of Rifle. The site can be accessed from U.S. Highway 6 at a point approximately 1.1 miles to the west of the intersection of U.S. Highway 6 and State Highway 13 
Bypass. The 142-acre site is bounded by the D\&RGW Railroad and U.S. Highway 6 on the north, Colorado River on the east and by Colorado River and Interstate 70 on the south. The site is located in Section 18, T6S, R93W, 6th PM, Garfield County.

b. The contaminated uranium mill tailings are located in a 33-acre tailings pile approximately in the west-central part of the 142-acre site. The rest of the site is comprised of mill areas, ore storage areas, vanadium and evaporation ponds.

3. Estes Gulch Disposal Site:

a. The Estes Gulch Disposal site (also referred to in the Subcontract Documents as the Estes Gulch Site or Disposal site) is located approximately 6 miles north of the town of Rifle along state Highway 13 . A short stretch of unimproved road off Highway 13 presently provides access to the site. The site is located within section 14, T5S, R93W, 6th PM, Garfield county.

b. The Estes Gulch Site is approximately 9 miles to the north of the old Rifle tailings site, via U.S. Highway 6 and state Highway 13, and approximately 7 miles to the north of the New Rifle tailings site. All truck traffic shall use Highway 13 Bypass.

1.2 SCOPE OF WORK

A. General: The work generally consists of excavating and removing all contaminated residual radioactive materials from the abandoned uranium processing sites (including stockpiled material from vicinity properties) at old and New Rifle sites and from the windblown and waterborne offsite areas, and disposal and consolidation of this material in a partially below-grade contoured tailings embankment at the Estes Gulch site. The embankment will be provided with a protective cover. All three sites and borrow areas shall be graded and provided with protective cover to prevent erosion. The work is more fully detailed in the specifications and the subcontract Drawings included herein.

B. The work includes:

1. Mobilization: Mobilization, as specified in section 01019 .

2. Construction Facilities: Construction facilities and access roads as required for access to the sites and

Document No. 3885-RFL-S-01-00730-04

Issued for construction-Revision 1 
borrow areas, as shown on the subcontract Drawings and as specified in section 01500.

3. Existing Utilities: Protection and removal of existing utilities, as shown on the subcontract Drawings and as specified in section 02050 .

4. Sealing of existing monitor wells, as specified in Section 02090 .

5. Construction of temporary fencing, as shown on the subcontract Drawings and as specified in sections 02832 , 02833 and 02835 .

6. Access control staging area and decontamination pads construction at Estes Gulch, as shown on the subcontract Drawings and as specified in sections 01500 and 02230.

7. [Construction of drainage ditch and retention basin at the Estes Gulch Disposal Site for conveying and retaining contaminated runoff water leachate and sediment generated on-site, for use in dust control in contaminated areas, or for treatment, as specified in sections 02141 and 02771]$.

8. Excavation of Disposal Cell Foundation at Estes Gulch.

9. Dewatering and Drainage Facilities, Including a slurry Trench at old Rifle: Dewatering ground water from excavations at the old Rifle and the New Rifle Processing sites by gravity drainage system or by pump system or by combination of both systems. Water from contaminated areas at the Estes Gulch Disposal Site shall be collected in the wastewater retention basin prior to its use for dust control or compaction in the construction of the tailings embankment. Water from uncontaminated areas shall be diverted to the designated discharge points. Silty water from uncontaminated areas shall be diverted into the nearby natural drainage courses via temporary detention pond or other similar facilities. Dewatering and drainage work is specified in Section 02141.

10. Construction of drainage ditches at the processing sites to divert runoff of uncontaminated water as shown on the subcontract Drawings and as specified in sections 02141 and 02200 .

* P.I.D. 06-S-17

$$
\begin{aligned}
& \text { Document No. } 3885-R F L-S-01-00730-04 \\
& \text { Issued for Construction-Revision } 1
\end{aligned}
$$


11. Excavation of contaminated materials from the old Rifle and the New Rifle Processing sites and foundation excavation at the disposal site, as specified in section 02200 .

12. Earthwork for retention basin, ditches, decontamination pad, and the like, as specified in Section 02200.

13. Construction of Tailings Embankment: Construction of tailings embankment at the Estes Gulch Disposal site using tailings and other contaminated materials resulting from excavations at old Rifle Processing Site, New Rifle Processing site, contaminated materials from vicinity properties delivered to the processing sites by others, offsite windblown and waterborne areas, debris resulting from the demolition of structures, and sediments from retention basins, [as specified in Sections 02200 and $02050 \mathrm{~J}$. Construction of the tailings embankment shall also include foundation excavation [and installation of a leachate collection and removal system, as specified in section 02144]*.

14. Site Restoration: After the removal of contaminated material, the excavated areas on and around the two processing sites shall be restored by backfill, and graded, seeded, revegetated or riprapped as shown on the Subcontract Drawings and as specified in Sections 02200, 02935 and 02936 . On the disposal site, all excavated areas outside of the tailings embankment shall be graded and seeded as shown on the subcontract Drawings and as specified in Sections 02200 and 02935 . Permanent drainage ditches and grade areas at the Estes Gulch Disposal Site shall be protected by rock riprap as shown on the Subcontract Drawings, and as specified in section 02278.

c. The above description of the Work is for general information only, and in no way limits the responsibility of the Subcontractor for constructing the work in strict accordance with the Subcontract Drawings and Specifications listed in the Table of Contents.

D. Environmental Observations: The Work shall be performed in strict accordance with the applicable requirements of the U.S. Environmental Protection Agency, City of Rifle, Garfield County, the Colorado Department of Health, and other involved state and federal agencies (see Article SC-11 of special Conditions for list of permits) having jurisdiction, and in accordance with the requirements of General Provisions, General Conditions and Special Conditions.

* P.I.D. 06-S-17

Document No. 3885-RFL-S-01-00730-04

Issued for Construction-Revision 1

Summary of Work

5402 S/WP5 1

RFL-PH-II

$01010-4$

121991 
A. The following subcontracts awarded by the contractor for other work may be in progress during the term of this subcontract. The contractor or his authorized representative will be responsible for coordinating all activities between the subcontractors in accordance with the requirements of Article SC-3. A of the special Conditions. The other subcontract will be designated as:

1. Removal and disposal of other unidentified waste materials.

2. Excavation of contaminated materials from the vicinity properties areas and transport of these materials and unloading at the New Rifle site.

[Text Deleted]*

\subsection{CONSTRUCTION SEQUENCE}

A. Unless otherwise specified, directed, or modified, the Subcontractor shall follow the following recommended sequence of operations as set forth below. Modifications to this sequence shall be subject to the Contractor's approval. Full compensation for conforming to such requirements will be considered to be included in the Bid schedule items of Work and no additional compensation will be allowed therefor.

B. Meetings will be conducted between the contractor and subcontractor prior to starting each sequence of construction listed below. The intent of these meetings is to review and discuss specification requirements for that particular sequence of construction. During these meetings, the subcontractor shall present a written construction Plan that will outline and detail the equipment, personnel, schedule, and source, transportation, excavation, placement and compaction of materials proposed for each construction sequence as applicable.

*P.I.D. $06-S-17$ 
C. Sequence of Operations:

1. Mobilization at the Estes Gulch Disposal Site, New Rifle and old Rifle Processing Sites.

2. Construct the access road from state Highway 13 to the Estes Gulch Disposal Site.

3. Clearing and grubbing.

4. Seal wells.

5. Construct temporary fencing around the Estes Gulch Disposal site. Construct temporary facilities such as access control, parking, water and sanitary facilities, temporary power to radiological equipment monitors, as specified in section 01500 .

6. Construct the temporary interceptor ditch on the north side of the Estes Gulch Site, as shown on the Subcontract Drawings.

7. Excavate tailings embankment foundation at the Estes Gulch Disposal Site. Selected portions of the excavated materials shall be separately stockpiled in designated area(s) for later use for construction of the radon barrier and frost barrier. The remaining materials shall be transported to the old Rifle and the New Rifle Processing sites for use as backfill for finish grading of the sites. For transporting excavated material from the Estes Gulch site to the two Rifle sites for site restoration, the subcontractor may, at his discretion, and as far as practicable, coordinate his excavation and fill activities at all three sites such that minimum or no stockpiling will be required.

8. Install HDPE liner at the toe of the tailings embankment at the disposal site.

9. [Construct temporary drainage ditch and retention basin at the disposal site.]*

[Text Deleted]*

[10.]* Install leachate collection and removal system within the tailings embankment at the disposal site.

* P.I.D. 06-S-17

Document No. 3885-RFL-S-01-00730-04

Issued for Construction-Revision 1 
[11.]* Excavate the tailings piles at the old Rifle and the New Rifle Processing sites down to a level which is just above the water table. When water is no longer needed for dust and moisture control, the existing sprinkler system at the New Rifle Processing Site shall be removed, demolished and disposed of as specified in section 02050 . Haul the tailings to the Estes Gulch Disposal site and place the tailings in the tailings embankment. Follow the order of excavation of contaminated materials from various areas in and around the two tailings sites as shown on the subcontract Drawings.

[NOTE: Contaminated demolished materials at the old and New Rifle sites]* shall be loaded and hauled to Estes Gulch and placed in the embankment concurrently with placement of the tailings.

[12.]* Disconnect and remove existing utilities not required for Phase II Work including sealing of monitor wells located in the tailings excavation areas at the two processing sites. Utilities and wells that are to be saved shall be protected during the tailings excavations as specified in Section 02090.

[13.]* Install dewatering and drainage facilities as needed at the two processing sites. [Install slurry trench at old Rifle and New Rifle.]*

[14.]* Excavate the remainder of the main tailings piles at the two processing sites to finish grade elevations while dewatering and placing the tailings at the disposal site. Complete excavation of contaminated materials from all areas in and around the two processing sites (the tailings piles, offsite windblown areas), and complete placement of these materials in the tailings embankment at the disposal site.

[15.]* Load, haul, spread and compact vicinity property contaminated material from stockpile at New Rifle to Estes Gulch tailings embankment.

[16.]* Remove sediments from the retention basins, ditches, and holding ponds/tanks of the old Rifle and the New Rifle Processing sites, and transport to the Estes Gulch Disposal site for disposal in the Estes Gulch tailings embankment.

* P.I.D. $06-S-17$ 
[17.]* Remove synthetic membrane liners from the ditches, retention basins and spillways of the old Rifle and the New Rifle processing sites, and dispose of in the tailings embankment.

[18.]* Demolish decontamination pads at the old Rifle and the New Rifle Processing sites, and dispose of in the tailings embankment.

[19.]* Process and stockpile riprap and drain and filter material.

[20.]* Begin construction of the radon barrier on the tailings embankment.

[21.]* Construct permanent interceptor ditch at tailings embankment.

[22.]* When radon barrier placement is nearly complete, remove, treat and discharge any water remaining in the retention basin and holding ponds/tanks and remove sediments from the retention basins, ditches, and holding ponds/tanks of the Estes Gulch Disposal Site, and dispose of in the tailings embankment.

[23.]* Remove synthetic membrane liners from the ditches, retention basins and spillways, demolish decontamination pads, and demolish any of the temporary facilities that cannot be decontaminated, and dispose of the debris in the tailings embankment.

[24.]* Remove any contaminated materials underlying retention basins and drainage ditches.

[25.]* Complete construction of radon barrier and layer of erosion protection material on top of the radon barrier.

[26.]* At the disposal site, restore the wastewater retention basin area and complete final site grading and provide erosion protection. Construct the toe ditch south of the tailings embankment and provide erosion protection.

[27.]* Complete restoration of the two processing sites to their final grades including filling of all excavated areas, temporary ditches and retention basin areas. The excess material obtained from permanent ditch excavations and final site grading of the disposal site shall be used for

* P.I.D. 06-S-17 
this purpose. Also see related Item 4 of this construction sequence. The final step of site restoration will be seeding, revegetating and providing a layer of riprap protection in designated areas.

[28.]* Remove access control, monitoring and staging areas at the two processing sites and the disposal site. Remove perimeter fencing and gate at the disposal site.

[29.]* Demobilize from all three sites.

1.5 SUBCONTRACT DRAWINGS

A. A list of subcontract Drawings and Titles is given in the Table of contents of these subcontract Documents under "Subcontract Drawings".

B. Where "as shown," "as detailed," "as noted," or words of like meaning are used in the subcontract Documents, it shall be understood that reference is being made to the subcontract Drawings unless otherwise specified.

1.6 TIME OF COMPLETION

A. The term of the subcontract shall be 1510 calendar days from the receipt of Notice to Proceed.

B. Termination for default, damages for delay and time extensions are specified in Article GP-56 of the General Provisions.

1.7 CODES AND STANDARDS

A. Pursuant to Article GC-3 of the General Conditions, any material, method, or procedure specified by reference to the number, symbol, or title of a specific specification or standard, such as a Commercial standard, American National standard, Federal or state specification, Industry or Government Code, a trade association code or standard, or other similar standard, shall comply with the requirements in the latest revision thereof and any amendments or supplements thereto in effect on the date of Award of the subcontract, except as limited to type, class or grade, or modified in such reference.

* P.I.D. 06-S-17 
B. The code, specification or standard referred to, except as modified in these specifications, shall have full force and effect as though printed in these specifications. These specifications and standards are not furnished to bidders since manufacturers and trades involved are assumed to be familiar with their requirements. The contractor will furnish, upon request, information as to how copies of the specifications and standards referred to may be obtained.

\subsection{MANUFACTURERS' SPECIFICATIONS AND INSTRUCTIONS}

A. Unless otherwise indicated or specified, all manufactured materials, products, processes, equipment, or the like shall be installed or applied in accordance with the manufacturers' instructions, directions, or specifications. Said installation or application shall be in accordance with printed instructions furnished by the manufacturer of the material or equipment concerned for use under conditions similar to those at the jobsite. Two copies of such instructions shall be furnished to the contractor and his acceptance thereof obtained before work is begun.

B. Any deviation from the manufacturers' printed recommendations shall be explained and acknowledged as correct for the circumstances, in writing by the particular manufacturer. Subcontractor will be held responsible for all installations contrary to the manufacturers' recommendations. If any item of material or equipment is found to be installed not in accordance with the manufacturer's recommendations, Subcontractor shall make all changes necessary to achieve such compliance without additional cost to the contractor.

1.9 WORK QUALITY

A. Shop and field work shall be performed by qualified craftsmen. All work on this Project shall be performed in accordance with the best practices of the various trades involved and in accordance with the subcontract Drawings, reviewed shop drawings, and these specifications.

B. All Work shall be erected and installed plumb, level, square and true, or true to indicated angle, and in proper alignment and relationship to the work of other trades. All finished work shall be free from defects and damage.

c. The Contractor reserves the right to reject any materials and work quality which are not considered to be up to the highest standards of the various trades involved. Such inferior material or work quality shall be repaired or replaced, as directed, at no additional cost to the contractor.

Document No. 3885-RFL-S-01-00730-04

Issued for Construction-Revision 1

Summary of Work 


\subsection{FIELD MEASUREMENT AND TEMPLATES}

Subcontractor shall secure all field measurements required for proper and accurate fabrication and installation of the work included in this subcontract. Exact measurements are the subcontractor's responsibility. Subcontractor shall also furnish or obtain all templates, patterns, and setting instructions required for the installation of all work. All dimensions shali be verified by the Subcontractor by survey in the field.

1.11 ACCESS TO WORK

A. Pursuant to the provisions of Article GC-17 of the General Conditions, the authorized agents of the following agencies will also have the right of access to inspect the Work covered by these subcontract Documents during the performance of this subcontract:

1. United States Department of Energy (DOE)

2. United States Nuclear Regulatory Commission (NRC)

3. Colorado Department of Health, Hazardous Materials and Waste Management Division

4. Various Agencies Listed in Article sC-11 of the Special Conditions

5. Other Local, State and Federal Agencies

B. The inspections will be performed in conjunction with an inspection by the contractor. Reasonable facilities for the proper handling and inspection of the materials and the Work shall be furnished by the subcontractor.

\section{PART 2 - PRODUCTS}

(Not Used)

PART 3 - EXECUTION

(Not Used)

PART 4 - MEASUREMENT AND PAYMENT

(Not Used) 


\section{SECTION 01019}

\section{MOBILIZATION}

\section{PART 1 - GENERAL}

\subsection{SCOPE}

A. This Specification section covers the following:

1. Organization and mobilization of Subcontractor's forces and equipment;

2. Transporting construction plant and equipment to the site and setting up of same;

3. Transporting tools, materials, and equipment to the site; and

4. Furnishing, installation, construction, maintenance, operation, and subsequent removal and disposal of construction facilities and temporary controls not separately paid for under other sections of subcontract Documents but required for construction of permanent facilities.

5. Subsequent removal of construction equipment, materials and supplies; decontamination of equipmert and facilities; cleaning of equipment for salvage; cleaning of the site; and restoration and reseeding of offsite construction facilities.

\subsection{RELATED WORK}
A. Section 01500 - Construction Facilities
B. Section 01560 - Temporary controls
c. Section 01561 - Construction Cleaning

\subsection{DESCRIPTION}

A. Mobilization shall include:

1. Furnishing, installation/construction of construction facilities identified in Article 1.1.A.4 above, and mobilization of all construction equipment, materials,

Document No. 3885-RFL-S-01-00731-03

Issued for Construction-Revision 0 
supplies, appurtenances, and the like, manned and ready for commencing and performing the Work.

2. Assembly and delivery to the site of plant, equipment, materials, and supplies necessary for the performance of the Work but which are not intended to be incorporated in the work; the preparation of the subcontractor's work area; the complete assembly, in safe working order, of equipment necessary to perform the required work; personnel services preparatory to commencing actual work; and all other preparatory work required to permit commencement of the actual work on construction items for which payment is provided under the subcontract.

3. Decontamination of construction facilities, equipment, materials, supplies and appurtenances.

4. Subsequent removal from the site of all construction equipment, materials, supplies, appurtenances, and the like upon completion of the work.

5. Maintenance, operation, subsequent removal and disposal of construction facilities identified in Article 1.1.A.4 above, as required by the contractor, cleaning of the site, and restoration and reseeding of offsite construction facilities.

\section{PART 2 - PRODUCTS}

(Not Used)

PART 3 - EXECUTION

(Not Used)

PART 4 - MEASUREYENT AND PAYMENT

4. 1 MEASUREMENT

Measurement for payment for mobilizarion will be by the lump sum basis. 


\subsection{PAYMENT}

A. [Payment for mobilization will be made at the lump sum price quoted therefor in the Bid schedule, and shall include all items as specified herein.]* Payment for mobilization will be made as follows:

1. Payment of 50 percent of the lump sum price will be made upon completion of "move-in". Move-in is defined as organization of the subcontractor's manpower and equipment, transporting equipment to the site, and installation of subcontractor's field office and other supporting structures.

2. Payment of the remaining 50 percent of the lump sum price will be made upon completion of work corresponding to 10 percent of the total price quoted in the Bid schedule exclusive of the price quoted for mobilization.

B. Payment for furnishing, installing, operating, maintaining, decontaminating, removing and disposal, if required, of construction facilities not specifically included for payment under any other Bid Items will be considered to be included in the Bid Schedule item for Mobilization.

END OF SECTION 01019

* Revision 
PART 1 - GENERAL

\subsection{SCOPE}

A. This specification section covers descriptions of measurement and payment as they apply to this subcontract. The provisions of this section shall be supplemental to the requirements specified in General Provisions, General conditions and special conditions.

B. Measurement methods specified in the individual sections of these specifications shall govern if they differ from methods specified in this section.

C. The subcontractor shall compute all quantities. Such computations shall be based upon surveys performed by the subcontractor and subject to approval by the contractor before any progress payments related thereto are made.

\subsection{RELATED WORK}

A. General Provisions - Article GP-38: Payments to Subcontractors

B. General Conditions - Article GC-4B: Progress Payments

C. Section 00800 - Special Conditions: Article SC-14, Variations in Quantities

D. Section 01052 - Layout of Work and Surveys

E. Section 01300 - Submittals: Schedule of Values and Progress Payment schedule

\subsection{MEASUREMENT OF QUANTITIES}

A. Measurement standards: All work to be paid for at a Contract price per unit of measurement will be measured in accordance with United States Standard Measures. A ton shall consist of 2,000 pounds avoirdupois. 
B. Measurement by Weight:

1. Reinforcing steel, steel shapes, castings, miscellaneous metal, metal fabrications, and similar items, to be paid for by weight, shall be measured by scale or by handbook weights for the type and quantity of material actually furnished and used.

2. Material to be measured and paid for by scale weight shall be weighed on accurate, Contractor-approved scales, furnished by and at the expense of the subcontractor. Use platform scales of sufficient size and capacity to permit the entire vehicle or combination of vehicles to rest on the scale platform while being weighed. Combination vehicles may be weighed as separate units provided they are disconnected while being weighed. All scales shall be inspected and certified as often as the Contractor may deem necessary to ascertain accuracy. costs incurred, as a result of regulating, adjusting, testing, inspecting, and certifying scales, shall be borne by the subcontractor.

3. The Contractor may be present to witness the weighing and to check and compile the daily record of such scale weights; however, in any case, the contractor will require that the subcontractor furnish weigh slips and daily summary weigh sheets. A duplicate weigh slip or a load slip for each vehicle weighed shall be delivered to the contractor at the point of delivery of the material.

4. If the material is shipped by rail, the certified car weights will be accepted, provided that only actual weight of material will be paid for and not minimum car weight used for assessing freight tariff. Car weights will not be acceptable for material to be passed through mixing plants.

5. Trucks used to haul material being paid for by weight, shall be weighed empty daily and at such additional times as the contractor may require. Each truck shall bear a plainly legible identification mark. The contractor may require the weight of the material verified by weighing empty and loaded trucks on such other scales as the contractor may designate.

C. Measurement By Volume:

1. Measurement by volume will be by the cubic dimension listed or indicated in the Bid schedule. Method of volume measurement will be as specified in the applicable

Document No. 3885-RFL-S-01-00732-04

Issued for Construction-Revision 1

Measurement and Payment 
Section of the specifications or as determined or directed by the contractor.

2. When material is to be measured and paid for on a volume basis and it is impractical to determine the volume by the specified method of measurement, or when requested by the subcontractor in writing and accepted by the Contractor in writing, the material will be weighed in accordance with the requirements specified for weight measurement. Such weights will be converted to volume measurement for payment purposes. Factors for conversion from weight measurement to volume measurement will be determined by the Contractor and shall be agreed to by the subcontractor before such method of measurement of pay quantities will be accepted.

D. Measurement by Area: Measurement by area will be by the square dimension listed or indicated in the Bid schedule. Method of square measurement will be as determined or directed by the contractor.

E. Linear Measurement: Linear measurement will be by the linear dimension listed or indicated in the Bid Schedule. Method of linear measurement will be as determined or directed by the Contractor. Generally, items, components, or work to be measured will be measured at the centerline of the item in place.

F. Lump-Sum Measurement:

1. Lump-sum measurement will be for the entire item, unit of work, structure, or combination thereof, as listed or indicated in the Bid schedule.

2. If the Subcontractor requests progress payments for lumpsum items or amounts in the Bid schedule, such progress payments will be made in accordance with a schedule of Values for that item as specified in specification Section 01300 and Article GC-4B of the General Conditions.

1.4 FIELD MEASUREMENT FOR PAYMENT

A. The subcontractor shall compute all quantities of Work performed or of materials and equipment delivered to the site, for payment purposes. All such computations shall be subject to approval by the contractor before any progress payments related thereto are made.

Document No. 3885-RFL-S-01-00732-04

Issued for Construction-Revision 1

Measurement and Payment 
B. The Contractor may, at any time, verify quantities calculated by the subcontractor in accordance with the provisions of Section 01052 of these specifications.

C. The Subcontractor shall assist the contractor in the taking of measurements by providing all equipment, workers, and survey crews, as required, for verification of quantities by the contractor in accordance with the provisions of section 01052 of these specifications.

D. All such assistance in measurement services required of the Subcontractor, as specified, shall be performed under the direction and supervision of the contractor.

1.5 PAYMENT

A. Payment wiil be full compensation for furnishing all labor, materials, tools, equipment, transportation, services, and incidentals, as specified, in Article GP-38 of the General Provisions and Article GC-4B of the General conditions, and for performing all work necessary for completing the erection or installation of the item or work classification, including all adjusting and balancing, testing, cleaning, and all other incidental work.

B. Full compensation for all expense involved in conforming to the requirements for measuring materials or work shall be considered as included in the unit or lump-sum prices paid for the materials or work being measured, and no additional compensation will be permitted therefor.

[C. When progress payments are to be made on a portion, area, or section of the work, that portion, area, or section of the work shall be clear of deficiencies and nonconforming items, as determined by the contractor, prior to making a progress payment. ]*

\subsection{VALUES OF UNIT PRICES}

A. The number of units and quantities contained in the Bid Schedule are approximate only, and final payment will be made for the actual number of units and quantities which are incorporated in or made necessary by the work included in this subcontract.

* P.I.D. 06-S-17

Document No. 3885-RFL-S-01-00732-04

Issued for Construction-Revision 1

Measurement and Payment 
B. In the event that work and/or materials or equipment are required to be furnished to a greater or lesser extent than is indicated by the subcontract Drawings and specifications, such work and/or materials or equipment shall be furnished in greater or lesser quantities, and the adjustment in unit price shall be made as specified in Article SC-14 of the Special Conditions.

\subsection{REJECTED MATERIALS}

Quantities of material wasted or disposed of in a manner not called for under the subcontract; rejected loads of material, including material rejected after it has been placed by reasons of the failure of the subcontractor to conform to the provisions of the subcontract; material not unloaded from the transporting vehicle; material placed outside the limits indicated on the subcontract Drawings or established by the Contractor; or material remaining on hand after completion of the Work, will not be paid for, and such quantities shall not be included in the final total quantities. No compensation will be permitted for loading, hauling, and disposing of rejected material.

PART 2 - PRODUCTS

(Not Used)

PART 3 - EXEC.UTION

(Not Used)

PART 4 - MEASUREMENT AND PAYMENT

4.1 MEASUREMENT

Separate measurement for payment will not be made for work required under this section.

\subsection{PAYMENT}

Separate payment will not be made for work required under this section. All costs in connection with the work specified herein will be considered to be included in the related item of work in the Bid Schedule, or incidental to the subcontract.

END OF SECTION 01025 
SECTION 01052

IAYOUT OF WORK AND SURVEYS

\section{PART 1 - GENERAL}

\subsection{SCOPE}

A. This specification Section covers the procedures and accuracy requirements for survey services for the following:

1. Layout of Work

2. Field measurement of work quantities.

3. Locations of sampling and testing performed by the Contractor.

4. Determination of as-built locations, lines, and grades at completion of the work for preparation of as-built drawings as specified in section 01300.

B. Before commencing any layout of work and surveys, the subcontractor shall give the contractor five working days written notice in advance so that the contractor may witness such work.

\subsection{DESCRIPTION}

A. Reference Points: The reference points to be provided by the Contractor will include referenced monuments and elevation bench marks in the vicinity of the project. Initial reference points will be furnished by the contractor. Replacement by the contractor of Contractor-established reference points which have been damaged or destroyed by the Subcontractor will be charged to the subcontractor at a rate of $\$ 150$ per hour. All other necessary reference points shall be established by the subcontractor.

B. The subcontractor shall furnish all necessary detail surveys including all lines, grades, and appropriate surveys as specified.

c. The Contractor reserves the right to perform any desired checking and/or correction of the Subcontractor's surveys but this shall not relieve the subcontractor of responsibility for the adequate performance of the work.

D. Equipment and Personnel: The Subcontractor's instruments and other survey equipment shall be accurate, suitable for the 
surveys required in accordance with recognized professional standards, and in proper condition and adjustment at all times. A competent surveyor shall perform the work.

E. Field Notes and Records: The subcontractor shall record surveys in duplicate page field notebooks. The original pages of such records shall be furnished to the contractor at intervals required by the contractor. A duplicate of each field notebook shall be furnished to the contractor when filled or completed or to meet the requirements of Article GC-4, Progress Payment.

F. Use by the Contractor: The Contractor may at any time use line and grade points and markers established by the subcontractor. The subcontractor's surveys are a part of the Work and may be checked by the contractor or representatives of the contractor at any time. The subcontractor shall be responsible for any lines, grades, or measurements which do not comply with specified or proper tolerances, or which are otherwise defective, and for any resultant defects in the work. The subcontractor will be required to conduct resurveys or check surveys to correct errors indicated by review of the field notebooks or otherwise detected.

1.3 SURVEYS FOR LAYOUT AND PERFORMANCE OF WORK

The subcontractor shall perform all surveys for layout and performance of the Work, and shall reduce the field notes and make all necessary calculations and drawings necessary to carry out the work.

\subsection{SURVEYS FOR MEASUREMENT FOR PAYMENT}

When the specifications or the contractor require Bid Schedule items of work to be measured by surveying methods, the subcontractor shall perform the surveys. All such surveys, including control surveys run for establishing the measurement reference lines, shall be performed in the presence of the contractor (or a representative of the Contractor) who will witness the surveying operation by signing the field notes or keeping duplicate field notes, at the Contractor's option. The subcontractor shall reduce the field notes and calculate final quantities for payment purposes. [A duplicate of the note reductions and calculations shall be given to the contractor.]*

* Revision

Document No. 3885-RFL-S-01-00733-03

Issued for Review-Revision 0 
1.5 SURVEYS FOR CONTRACTOR SAMPLING AND TESTING LOCATIONS

A. The subcontractor shall perform surveying services as specified herein for the locations of contractor sampling and testing.

B. [Text Deleted]* [Not Used]*

C. Materials Sampling and Testing: The subcontractor shall provide surveying services to locate positions, both plan and elevation, of in-place material sampling and testing locations used by the Contractor. The number of sampling and testing locations will be determined by the associated Specification section.

D. The Subcontractor shall mark sampling locations for radiologic samples in the tailings embankment at locations shown on the Drawings and as specified herein. As contaminated materials are placed in the uppermost 20 feet of contaminated materials, the subcontractor shall mark each location at each 2-foot increment of elevation.

E. All sampling and testing location information shall be submitted in writing to the contractor showing coordinates and elevations.

1. 6 SURVEYS FOR AS-BUILT CONDITIONS

A. The Subcontractor shall provide surveying services for asbuilt conditions as specified herein.

B. The subcontractor shall provide survey data to confirm that as-built locations of the work conform to the subcontract Drawings where coordinates and, or elevations are shown.

c. Where the subcontract Drawings or specifications permit variable locations or detail for specific items of the work, the subcontractor shall survey the as-built locations or details. Surreys shall be sufficient to define the features or details at any given location.

D. The Subcontractor shall survey as-built elevations, at each location shown on the subcontract Drawings for radiologic sampling of the tailings embankment, for the as-built finished top surface of the following:

* Revision 
1. Contaminated materials

2. Radon barrier

[3. Drain layers D1 and D2

4. Frost barrier]*

[5. $]$ * Bedding

[6.]* RIprap

E. [The subcontractor shall survey as-built locations of all slope breaks for the tailings embankment and site grading.]*

F. The Subcontract Drawings shall be neatly marked in red ink with all as-built survey information and submitted to the Contractor in duplicate.

G. The requirements for submitting as-built survey data shall not relieve the subcontractor in any way from his responsibility to conform to the requirements of the Work.

[1.7 SURVEYING FOR DISPLACEMENT MONUMENTS

A. Displacement monuments shall be surveyed immediately following installation and thereafter on a weekly basis. The Subcontractor shall report the coordinates and elevation of the top of the 3/4-inch steel rod and the top of the 1-1/2 inch steel pipe as shown on the subcontract Drawings.

B. For displacement monuments having total lengths of steel rod and steel pipe greater than 5 feet, the subcontractor shall survey the top of the steel rod and steel pipe immediately prior to and following installation at each segment of steel rod or steel pipe during construction, as specified in Article 1.7.A.

c. The top of steel pipe shall be surveyed at the same location on the diameter of the pipe for each measurement.

D. Displacement monuments shall be surveyed immediately following any disturbance to any displacement monument.]*

1. [8]*SURVEYING ACCURACY AND TOLERANCES IN LAYOUT OF WORK

A. Tolerances in layout of Work shall not exceed the following:

* Revision 
Horizontal Position Elevation

Permanent reference points

1 in 10,000

$\pm .01 \mathrm{ft}$.

Reference points for

General excavation and

earthwork

1 in 2,000

$\pm .10 \mathrm{ft}$.

B. Tolerances for designed thicknesses shown on subcontract Drawings with the exception of erosion protection materials, [Text Deleted]* and for elevations shown on the Subcontract Drawings shall be \pm 0.10 foot. Tolerances for erosion protection material thickness are specified in Section 02278 .

c. These tolerances shall not supersede stricter tolerances required by the Drawings or specifications, or by the governing authorities, and shall not otherwise relieve the subcontractor of responsibility for measurement in compliance therewith.

PART 2 - PRODUCTS

(Not Used)

PART 3 - EXECUTION

(Not Used)

PART 4 - MEASUREMENT AND PAYMENT

4.1 MEASUREMENT

Separate measurement for payment will not be made for work required under this section.

\subsection{PAYMENT}

Separate payment will not be made for work required under this section. All costs in connection with the work specified herein will be considered to be included in the rel ited item of work in the Bid schedule, or incidental to the subcontract.

* Revision

END OF SECTION 01052

Document No. 3885-RFL-S-01-00733-03

Issued for Review-Revision 0

Layout of Work and Surveys 


\section{SECTION 01300}

\section{SUBMITTALS}

\section{PART 1 - GENERAL}

\subsection{DESCRIPTION}

A. This Specification section describes the requirements for the following submittals:

1. Technical Submittals:

a. Schedule of Technical submittals

b. Shop Drawings

c. Samples

d. Product Data

e. Certificates of Compliance

f. Manufacturer's Instructions

g. Design Calculations and Design Drawings

h. Winter Shutdown Plan

i. Drawings Showing Lines and Grades and Survey Data for Conditions at Completion of Construction (AsBuilt)

j. Erosion Protection Materials Production Plan

k. Hazardous and Non-Hazardous Material Subinittal

1. Proactive Dust Suppression Plan

[m. Operations Plan for each Decontamination Facility]*

2. General submittals:
a. Schedule of General Submittals
b. Site Mobilization schedule
c. Project Construction Schedule
d. Schedule of Values/Cost Profile
e. Hazard Communications Plan
f. Safety Plan
[g. Traffic Plan]*

3. Submittals Not Requiring Contractor's Approval:
a. Weekly status Reports
b. Weekly Manhour Reports/Equipment and Truck Hours Report/Maintenance Report
c. Certified Payroll
d. Monthly Construction Schedule Progress Updates
e. Labor and Equipment Rates
[f. Monthly Summary of Fuel Taxes and Vehicle Fees for Subcontractor's Trucks and Vehicles directly involved in the Tailings Hauling Operations]*

* P.I.D. 06-S-17 
B. The requirements specified in this section shall be supplemental to the requirements specified in General Provisions, General Conditions, Special conditions and any other requirements specified in individual sections.

c. All submittals shall be in the English language.

D. The Subcontractor shall submit all submittals to the site Manager. A reproducible copy of the submittal, marked "Information only," shall be sent to the subcontract Administrator by the subcontractor.

E. Technical and General submittals shall be numerically serialized by type, Technical submittal with a "T" prefix (T-1, $T-2, T-3$, etc.) and General Submittals with a "G" prefix $(G-1, G-2, G-3$, etc.).

F. The Site Manager will clearly label the submittals as follows and return to the subcontractor:

1. Approved

2. Approved as Noted

3. Revise and Resubmit

4. Rejected

5. Information only

G. When submittals are returned marked with either "Revise and Resubmit" or "Rejected" the Subcontractor shall make such revisions and corrections as required and resubmit the submittal with the same submittal number followed by R1 (Revision One). Example: T-5 - R1.

\subsection{TECHNICAL SUBMITTALS}

A. Schedule of Technical submittals:

1. The subcontractor shall prepare and submit a Technical Submittals schedule listing all technical submittals required in accordance with this section. The Technical Submittals schedule shall be submitted at the preconstruction meeting.

2. The Technical submitta?, Schedule shall separate submittals by major specification section. This schedule shall include submittal delivery dates, required return dates, material delivery dates, and other pertinent data which may be required to ensure that the project schedule is met by the subcontractor.

3. This schedule shall be continually updated to reflect progress and any additions or deletions to the submittal schedule. Copies of the updated schedule shall be

Document No. 3885-RFL-S-01-00734-04

Issued for Review-Revision 1 
furnished to the contractor during the first week of each calendar month.

B. Shop Drawings:

1. Shop drawings shall establish the actual detail of all manufactured or fabricated items, indicate proper relation of adjoining work, and incorporate minor changes of design or construction to suit actual conditions. Shop drawings shall be drawn to scale and shall be completely dimensioned.

2. Sheet sizes of shop drawings shall be $81 / 2$ inches $x 11$ inches, 11 inches $\times 17$ inches, or 22 inches $\times 34$ inches.

3. A clear space of 3 inches $\times 3$ inches shall be provided on each drawing for the contractor's review stamp and comments.

4. Shop drawings shall be submitted to the contractor in the form of a reproducible transparency, together with three blackline or blueline prints.

5. After the contractor has completed his review of shop drawings, he will return one print to the subcontractor indicating the approval status as described in Article 1.1.F.

6. The Contractor will review and generally return shop drawings within ten days of receipt by the site Manager but in no case will this process take longer than 30 days.

C. Samples:

1. The subcontractor shall furnish the contractor at least three samples of each of the various materials, together with the finish thereon, as specified for and intended to be used on or in the work. Samples shall be sent to the contractor.

2. The subcontractor shall submit all samples to the contractor at least 14 days (or earlier if so specified elsewhere) before purchasing, fabricating, applying, or installing such materials and finishes, unless otherwise stated. The contractor will review the samples for visual aspects such as kind, color, pattern, and texture, and will approve or ask for resubmittal of samples generally within 10 days but in no case longer than thirty days of the subcontractor's submittal. All

Document No. 3885-RFL-S-01-00734-04

Issued for Review-Revision 1 
approvals of samples will be given by the contractor in writing.

3. Unless otherwise specified in the various sections of these specifications, the subcontractor shall submit all samples, other than field samples, in triplicate. A cover letter shall accompany the sample and shall list all items being transmitted, designating their particular usage and location in the project.

4. After the contractor has performed his review and analysis of samples, two samples will be retained and the remaining sample will be returned to the subcontractor, with the contractor's comments.

5. Samples shall be submitted and resubmitted until approved as satisfactory. Approval of a sample shall not be taken in itself to change or modify any subcontract requirement.

All materials, color, pattern and texture in the completed building or structure shall be equal in every respect to that of the approved samples.

6. Each sample shall be identified completely as to product, color, manufacturer, trade name, lot, style, model, location of use, and subcontract Document reference, as well as the names of the subcontractor, supplier, Project and contractor.

7. Test samples, as designated by the Contractor, may also be selected from the materials or equipment delivered by the subcontractor to the site for use in the work. If any test sample fails to meet the specification requirements, such materials or equipment which fail the testing, shall be removed and replaced by the subcontractor with materials or equipment meeting the specification requirements.

8. Field samples shall be prepared at the site by the subcontractor in the manner and number as specified in these specifications. Affected finish work shall not be commenced until the contractor has approved the field samples, in writing.

D. Product Data:

1. Each copy shall be marked to identify applicable products, models, options, and other data; manufacturers' standard data shall be supplemented to provide information unique to the work.

Document No. 3885-RFL-S-01-00734-04

Issued for Review-Revision 1

Submittals 
2. The Subcontractor shall submit the number of copies which the subcontractor requires to be returned, plus two copies which will be retained by the contractor.

E. Certificates of Compliance: The Certificate shall clearly identify the applicable materials and reference the applicable sections of the subcontract Documents.

F. Manufacturer's Instructions: When required by the manufacturer's warranty requirements, the subcontractor shall submit manufacturer's printed instructions for delivery, storage, shelf life, assembly, installation, adjusting, and finishing.

G. Design Calculations and Design Drawings:

1. Design Calculations: When requested by the contractor, design calculations shall be submitted to the contractor for review with all pertinent data, assumptions, objective, criteria, applicable codes, standards and references. The calculations shall be on $8-1 / 2$ by 11inch or 11 by 17 -inch sheets. Each design calculation set shall bear page numbers, titles, revision numbers, date and calculation number. Where multiple number of items are designed in a particular system, the calculations shall be preceded by a table of contents.

2. Design Drawings:

a. When requested by the contractor, design drawings shall be submitted to the contractor for review.

b. Pertinent requirements of Article 1.2.B of this Section shall be applicable for submittal of design drawings.

H. Winter Shutdown Plan: A winter shutdown plan will be required for sites which will shutdown or limit operations for the winter season. This plan shall include grading modifications to drawings, product data and a narrative of the steps the subcontractor will take to address the following subjects:

1. Erosion from wind and water runoff of both contaminated and uncontaminated areas.

2. Slope protection.

3. Temporary ditching.

4. Grading of excavations and embankments to drain.

Document No. 3885-RFL-S-01-00734-04

Issued for Review-Revision 1 
5. Segregation of contaminated and non-contaminated runoff.

6. Reduction of water in the retention ponds to allow for spring snow melt.

7. Protection of all equipment and piping from damage due to freezing.

8. Other items may be required by the contractor such as personnel and equipment to maintain access and to prepare for emergency situations.

I. Drawings Showing Lines and Grades and survey Data for Conditions at completion of Work (As-Built): The Subcontractor shall prepare and submit at completion of work drawings showing lines and grades (as-built) and survey data for as-built conditions as specified in section 01052 .

J. Erosion Protection Materials Production Plan: See Section 02278, Article 1.6 .

K. Hazardous and Non-Hazardous Materials submittals: See Section 02081, Article 1.7.

L. Proactive Dust Suppression Plan: See Special Conditions, Article SC-3.D.

[M. Operations Plan for Each Decontamination Facility: See Section 01500, Article 1.15.G.

\subsection{GENERAL SUBMITTALS}

A. Schedule of General Submittals: The subcontractor shall prepare and submit a schedule of General submittals listing all General submittals required in accordance with the requirements of this section. The subcontractor shall prepare and make the initial submittal at the preconstruction meeting of all General submittals required.

B. Schedules and Reports:

1. The Subcontractor shall prepare and submit Schedules and Reports in accordance with the requirements of this Section.

2. The schedules and reports shall describe the subcontractor's work plan in sufficient detail as delineated below to provide:

a. Assurance to the contractor that the finished work complies accurately with the subcontract Documents,

Document No. 3885-RFL-S-01-00734-04

Issued for Review-Revision 1 
b. A basis for determining the progress of the work, and

c. A basis for the contractor's internal planning activities.

3. Within fifteen calendar days after Notice to Proceed, the Subcontractor shall provide the Contractor with initial copies of the General Submittals specified in this section. The cost profile shall be submitted within 15 calendar days.

4. The schedules shall be in a reproducible form and all of the same scale or may be combined as approved by the Contractor.

5. Unless otherwise specified, the schedules shall be presented in graphic format and shall be updated for each construction meeting, or at least monthly, and transmitted to the contractor.

6. The subcontractor shall obtain approval of the various schedules specified in this section before submitting the first application for payment. Schedule revisions also require contractor approval.

c. Site Mobilization Schedule:

1. Format: The subcontractor shall present, at the preconstruction meeting, the schedule for site mobilization in bar chart format. The schedule shall delineate the establishment of the construction facilities identified in Section 01500 and the Subcontractor's plan for starting the work.

2. Written Narrative: The Site Mobilization Schedule shall be accompanied by a written narrative discussion of the schedule. The narrative shall provide a man-power level by month for the first three months of the job, transportation routes proposed for delivery of major construction equipment to be used on the project, identification of special permits required and when they are needed, and a description of the temporary facilities to be provided.

3. Status and Progress: The status of mobilization schedule items shall be reported in the Weekly status Report discussed below.

Document No. 3885-RFL-S-01-00734-04

Issued for Review-Revision 1 
D. Project Construction Schedule:

1. Scheduling: A preliminary issue of the Project Construction Schedule shall be prepared for review at the preconstruction meeting. Fifteen days after receipt of Notice to Proceed the subcontractor shall issue the Project construction Schedule for approval and issue the approved Project Construction Schedule ten days after receipt of approval and comments from the contractor.

2. Format: The Project Construction Schedule shall consist of the following items, each compatible with the other and developed from the same basis:

a. Method of Construction Narrative

b. CPM Schedule: A time scaled Critical Path Method (CPM) Schedule which depicts proper restraints, activity durations, total float and free float for each schedule activity.

c. Critical Milestone Dates as listed below.

1) Start/complete mobilization at Estes Gulch Disposal Site, New Rifle and Old Rifle Processing Sites.

start/complete sealing of wells.

2) Start/complete tailings embankment foundation excavation at Estes Gulch Disposal Site.

3) Start/complete transportation of demolished materials and debris from the old Rifle and New Rifle Processing Sites to Estes Gulch Disposal Site.

4) Start/complete excavation and transportation of tailings from old Rifle and New Rifle Processing Sites to Estes Gulch Disposal Site.

5) Start/complete construction of slurry trench at old Rifle Processing site.

6) Start/complete construction of radon barrier and frost protection barrier at Estes Gulch Disposal Site.

7) Start/complete transportation and placement of erosion protection materials at Estes Gulch Disposal Site.

8) Start/complete site restoration at old Rifle and New Rifle Processing Sites and Estes Gulch Disposal Site.

Document No. 3885-RFL-S-01-00734-04

Issued for Review-Revision 1 
9) Start/complete demobilization.

d. Schedule of Values

3. Method of Construction: Method of construction submitted at the preconstruction meeting with the preliminary schedule shall be a written discussion of the Subcontractor's methods for completing the work. The subcontractor shall briefly describe his approach to the subcontract.

4. The Use of Schedule Float: In as much as the subcontractor's Schedule represents the Project construction Schedule, the calculated float for an activity is shared by the subcontractor and contractor. Adjustments to the schedule float will be equitably resolved by the contractor.

5. Computer Generated Schedule: The Subcontractor may generate the CPM schedule manually or by using a computer. The CPM Schedule shall include all significant items of work.

6. Comments Incorporated: The Subcontractor shall incorporate the contractor's comments into revisions of the Project Construction schedule, adjust the manpower loading as required and resubmit the schedule to the Contractor for approval along with a summary of the changes.

7. Revisions made to the schedule shall be given a new revision number and submitted to the contractor for approval. A written narrative shall accompany any changes to the logic and/or durations of the construction schedule. This narrative shall explain in detail what the change involves, the reason for the change, and any effect to the critical path of the schedule.

E. Schedule of Values/Cost Profile:

1. Each time a construction schedule is submitted, it shall be accompanied by a schedule of Values for the entire Scope of Work. The Schedule of Values shall conform to the format sample (01300-A) provided with this section. The Schedule of Values shall be based upon that specific revision of the Construction Schedule, and presented in such a format to clearly provide total period and cumulative cost information for each month for the entire duration of the subcontract. This schedule of Values shall be in a form which will provide a correlation between the subcontract bid items and the subcontractor's

Document No. 3885-RFL-S-01-00734-04

Issued for Review-Revision 1 
schedule activities. The subcontractor may, at his own risk, plan work in excess of the funding limitations outlined in the special conditions.

2. The format and the substance of the finalized Schedule of Values shall be as approved by the contractor.

\subsection{SUBMITTALS NOT REQUIRING CONTRACTOR APPROVAL}

A. The Subcontractor shall furnish the following submittals for information only. These submittals will not be approved and returned to the subcontract or.

1. Weekly Status Reports: The Subcontractor shall submit a Weekly status Report to the contractor by Friday noon. The report shall be on a form satisfactory to the Contractor, and shall include items such as a summary of Work completed and a Two-Week Look Ahead Bar Chart. Weekly status Report shall also include each major piece of equipment present on the site, its make, model, type, number of hours idle, number of hours used, etc. as required by the contractor.

2. Weekly Manhour Report/Equipment and Truck Hours Report/Maintenance Report: The subcontractor shall tabulate total manhours worked each week with a regular and overtime total, equipment hours of operation and truck miles driven each week, listing all data for subcontractor and lower-tier subcontractor operations. The tabulations shall be prepared and submitted weekly to the Contractor. The Maintenance Report shall be submitted to the contractor monthly as follows:

a. Preventative Maintenance:

\# Items Completed within Monthly Schedule \# Items Not Completed within Monthly Schedule

b. Corrective Maintenance:

\# Number of Corrective Work Requests During Month

Number of Corrective Work Requests Open at End of Month

3. Certified Payrolls: Certified Payrolls shall be submitted in strict compliance with section 10 of MKFerguson Company Standard Documents Package for proposed construction subcontracts.

Document No. 3885-RFL-S-01-00734-04

Issued for Review-Revision 1 
4. Monthly Construction Schedule Progress Updates: The Subcontractor shall submit an updated schedule, with the Critical Milestones clearly identified, by the first of each month. The status of the CPM schedule shall indicate percent complete by activity, remaining duration of in-progress activities, total float and free float for each schedule activity.

5. Labor and Equipment Rates: The subcontractor shall submit labor and equipment rates as stipulated in Subcontractor Labor and Equipment Rates of the Special Conditions.

[6. Monthly summary of Fuel Taxes and Vehicle Fees for Subcontractor's Trucks and Vehicles Directly involved in the Tailings Hauling operations: The Subcontractor shall submit a monthly summary of Fuel Taxes and Vehicle Fees paid to the state of colorado for all trucks and vehicles directly involved in the tailings hauling operations, listing all data for subcontractor and lower-tier subcontractors' operations. The subcontractor's submittal shall clearly identify all trucks and vehicles and submit daily haul mileage logs for trucks and vehicles used in the hauling operations with fuel consumption data and copies of fuel invoices. Copies of assessment statements and invoices for Fuel Taxes and Vehicle Fees paid to the state of Colorado shall also be submitted. Additional supporting data shall be submitted as required by the contractor. ]*

PART 2 - PRODUCTS

(Not Used)

PART 3 - EXECUTION

(Not Used)

\section{PART 4 - MEASUREMENT AND PAYMENT}

\subsection{MEASUREMENT}

Separate measurement for payment will not be made for work required under this section.

* P.I.D. 06-S-17

Document No. 3885-RFL-S-01-00734-04

Issued for Review-Revision 1 


\subsection{PAYMENT}

Separate payment will not be made for work required under this section. All costs in connection therewith shall be considered to be incidental to the applicable items of work to which they pertain.

END OF SECTION 01300

* P.I.D. 06-S-17

Document No. 3885-RFL-S-01-00734-04

Issued for Review-Revision 1 
G9.MK.FERGuson COMPANY

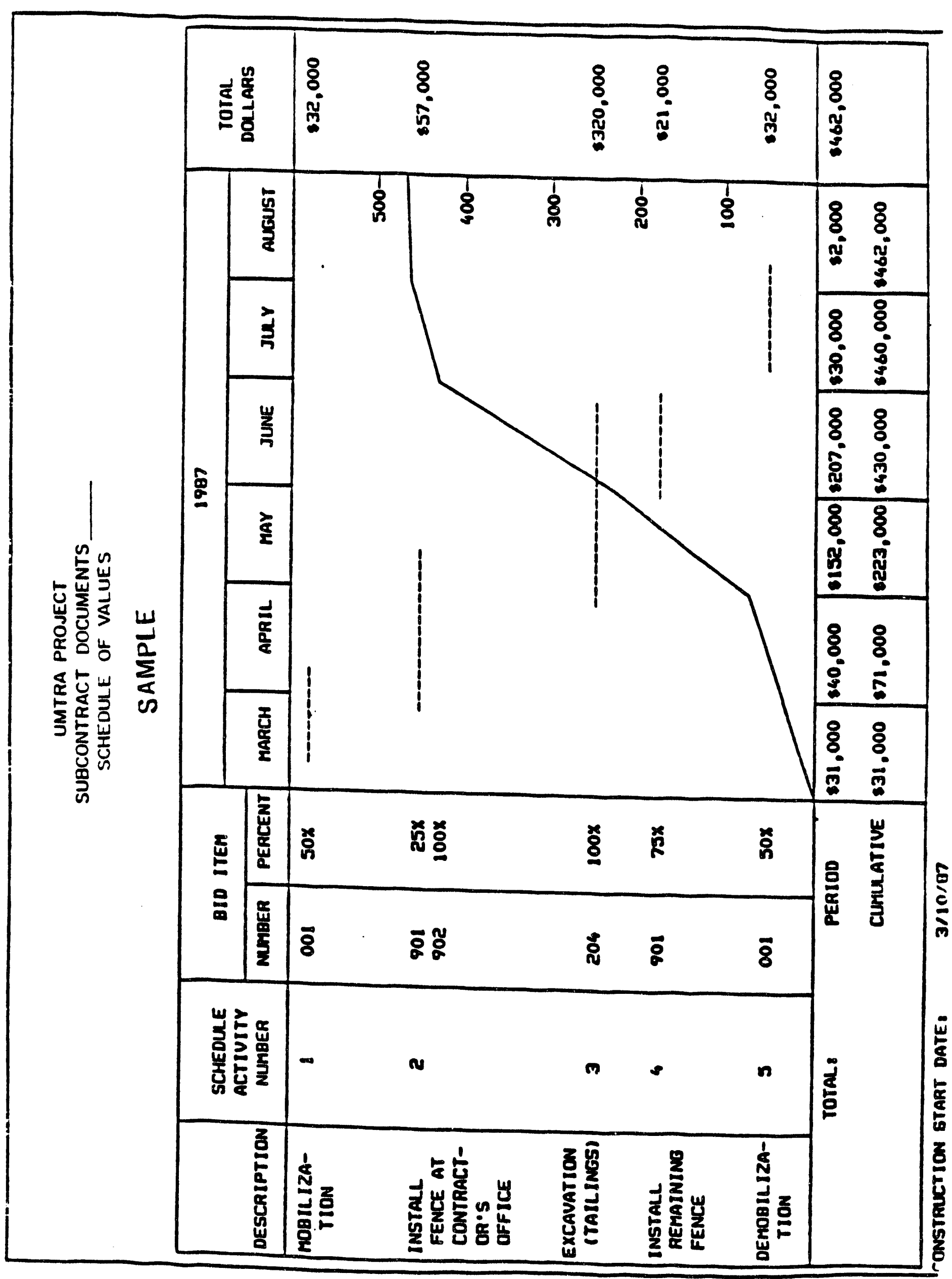




\section{SECTION 01500 \\ CONSTRUCTION FACILITIES}

PART 1 - GENERAL

1.1 SCOPE

A. This specification section covers the requirements for the construction facilities.

B. Construction facilities shall include, but not be limited to, the following temporary offices, utilities, equipment, materials and services:

1. Subcontractor's office

2. Contractor's office

3. Parking Areas

4. Janitorial Services

5. Snow Removal Services

6. Temporary Roads

7. Storage of Materials and Equipment

8. Construction Equipment

9. Temporary Sanitary Facilities

10. Temporary Electric Power

11. Temporary Water (Potable and Construction)

12. Decontamination Washwater Recycling system(s)

13. Temporary Heat

14. Temporary Telephone Service

15. Temporary Fences

[Text Deleted]*

c. The subcontractor shall be responsible for furnishing, installing, constructing, operating, maintaining, removing and disposing of the facilities as shown on the subcontract Drawings, as specified in this specification, and as required by the contractor for the completion of the Work under the subcontract.

D. All such temporary facilities shall be located as shown on the subcontract Drawings, or as directed, and maintained in a clean, safe and sanitary condition at all times until completion of the subcontract.

E. Upon completion of the subcontract, the temporary facilities shall be left in the status specified in Article 1.22 of this section.

* P.I.D. 06-S-17

Document No. 3885-RFL-S-01-00735-04

Issued for construction-Revision 1 
F. The requirements specified herein are in addition to any requirements specified elsewhere in the subcontract Documents. Temporary facilities shall meet the requirements for all-weather service.

G. All land disturbances related to the temporary facilities shall be minimized to the greatest extent possible and the land restored to the extent reasonable and practical, to its original contours by grading to provide positive drainage and by seeding the area to match with existing vegetation.

H. All utilities shall be designed and constructed to provide uninterrupted service during winter.

I. Certain faclities specified in this section, although referred to in singular, may be required in greater numbers. The number of facilities required shall be as shown on the Subcontract Drawings.

1.2 RELATED WORK

A. Section 00800 - Special Conditions: Definitions

B. Section 01019 - Mobilization: Payment

C. Section 01560 - Temporary Controls

D. Section 02050 - Demolition

E. Section 02200 - Earthwork

F. Section 02230 - Aggregate Base

G. Section 02832 - Chain Link Fence and Gates

H. Section 02833 - Woven Wire Fence

I. Section 02835 - Deer Fence and Gates

J. Section 02935 - Seeding

\subsection{AFPLICABLE PL̈BLICATIONS}

A. The Publications listed below form a part of this specification to the extent referenced. The publications are referred to in the text by the basic designation only:

1. UMTRA Project Construction Environment, Safety and Health Management Program (MK-UMTRA-4)

2. Colorado Highway Department:

"Standard Specifications", as applicable. 
3. Uniform Building code (UBC):

1988 Edition, applicable Chapters and sections.

4. National Fire Protection Association (NFPA), as applicable.

5. Occupational Safety and Health Administration, as applicable.

B. All required facilities, equipment and utilities shall also be constructed/installed, maintained and operated in accordance with applicable Federal, state, county, and Utility laws, rules, and regulations. Notwithstanding contrary provisions of General Provisions, General Conditions and Special conditions, nothing in the subcontract Drawings and specifications shall be construed to permit work not conforming to the above.

c. Unless otherwise specified elsewhere in the subcontract Documents, the subcontractor shall be responsible for obtaining applicable local, state and federal permits and for complying with the provisions of such permits.

1.4 SUBCONTRACTOR'S TEMPORARY OFFICE TRAILER(S)

A. Subcontractor shall furnish and install, in good condition, one or more temporary office trailer(s) of suitable sizes for himself and his office staff.

B. The location of the trailer(s) shall be approved by the contractor prior to setting in place. Other suitable office space in Rifle may be utilized at the subcontractor's option.

1.5 CONTRACTOR'S TRAILERS

A. Contractor-Furnished Trailers: Three Contractor-furnished trailers are presently being used as contractor's offices at the New Rifle site, as shown on the subcontract Drawings. Additionally, the subcontractor shall install the following Contractor-furnished trailer as shown on the subcontract Drawings:

1. Quality Control Trailer (Laboratory Trailer) at Estes Gulch Site, size: $12 \mathrm{ft}$. $x 40 \mathrm{ft}$.

B. [Subcontractor-Furnished Trailers: The Subcontractor shall furnish and install three Access Control Trailers, one laboratory trailer, two office trailers, and two heated shelters as listed below for use by the Contractor's staff. The final locations of the trailers shall be subject to approval by the contractor prior to setting in place.

Document No. 3885-RFL-S-01-00735-04

Issued for Construction-Revision 1 
1. Three Access Control Trailers with showers, each $12 \mathrm{ft}$. $x 60 \mathrm{ft}$. , located at Estes Gulch, New Rifle, and old Rifle sites.

2. Two office Trailers, each $12 \mathrm{ft}$. $x 60 \mathrm{ft}$, located at Estes Gulch and New Rifle sites.

3. One Laboratory Trailer, $12 \mathrm{ft}$. $x 40 \mathrm{ft}$, located at New Rifle site.

4. Two Heated Shelters, each $10 \mathrm{ft} . x 10 \mathrm{ft} . x 8 \mathrm{ft}$., located at New Rifle and old Rifle sites. The shelters shall be located near the decontamination pads constructed under this subcontract.

5. The subcontractor shall install a washer, dryer, and dishwater including utility hook-ups at access control trailer at New Rifle site. The Contractor will provide the appliances which are currently in storage at New Rifle site.

6. Trailers at Estes Gulch shall be erected prior to cell excavation activities.]*

c. Each trailer shall be provided with running water and power, and shall be properly lighted and temperature conditioned for summer and winter use. Wash basins and toilets shall be connected to sanitary facilities specified in Article 1.12. In addition, Access control Trailers and Quality Control Trailers shall be equipped with wash basins.

D. Each trailer shall be equipped with steps, stoops, handrailings, a deck at the door sill level, skirting all around the trailer, and trailer tie downs.

E. The Subcontractor shall furnish an outside sink with faucet for hand wash, an outside faucet for foot wash and a $6 \mathrm{ft}$. square concrete slab 6-inch thick with a 6-inch high curb and a 6-inch drain in the center of the slab draining to a contaminated discharge point. One such washing facility shall be furnished at each of the three sites.

\subsection{PARKING AREAS}

A. No personal vehicles will be permitted inside the construction work area. Vehicles used for construction purposes will be allowed inside the work area, but will be monitored for radioactive contamination at the access gate or control point before leaving the area.

* P.I.D. 06-S-17

Document No. 3885-RFL-S-01-00735-04

Issued for Construction-Revision 1 
B. An aggregate surfaced parking area exists at the New Rifle Processing site for delivery vehicles, the contractor's and subcontractor's representatives, and for other authorized visitors, as indicated on the subcontract Drawings. Parking shall be limited to the contractor's and subcontractor's office staff.

C. The subcontractor shall provide an aggregate surfaced parking area at the Estes Gulch Disposal site for maintenance and delivery vehicles, the contractor's and subcontractor's representatives, and for other authorized visitors, as indicated on the subcontract Drawings. Parking shall be limited to the contractor's and Subcontractor's office staff.

D. Any additional parking required shall be the responsibility of the subcontractor and subject to the contractor's approval.

1.7 MAINTENANCE AND JANITORIAL SERVICES

A. [The subcontractor shall provide daily maintenance and janitorial services including, but not limited to the three Access Control trailers, Quality control trailar, Contractor's office trailer at Estes Gulch, and the two shelters, including toilet facilities, and the access control area:]*

1. Sweep, vacuum, mop, and, if required, polish floors.

2. Clean toilets, doors and windows, office furniture.

3. Collect and dispose of office and yard solid waste.

4. Furnish toilet paper, hand towels, soap, cups, napkins, light bulbs, etc.

5. Operate and maintain trailer services including, but not limited to, the water supply and wastewater collection systems; heating, ventilating and air-conditioning system; and lighting and security systems, including doors, windows, steps, floors and lighting fixtures.

6. Janitorial services shall be provided throughout the term of the subcontract.

1.8 SNOW REMOVAL SERVICES

A. The Subcontractor shall provide snow removal services in the following areas throughout the term of the subcontract as required by the contractor.

* P.I.D. $06-S-17$

Document No. 3885-RFL-S-01-00735-04

Issued for construction-Revision 1

construction Facilities 
1. Walkways to the office trailers,

2. Parking areas,

3. Equipment and material storage areas, and

4. Access roads to sites and site facilities as necessary.

1.9 TEMPORARY ROADS

A. Temporary roads as defined in Article sc-1 of the special Conditions including an access road from State Highway 13 to the Estes Gulch Disposal site shali meet the following requirements:

1. Construction shall be conrdinated with and shall be as approved by the contractor.

2. [Thirty days prior to the start of any roadway work, the subcontractor shall submit, for review and approval, improvement drawings to the contractor to include requirements included in the BLM Permit and stipulations.]*

3. The Subcontractor shall coordinate all road construction activities with local utilities, regulatory agencies, fire and police departments, as applicable.

4. Erosion shall be kept to a minimum and suitable grades and radii of curves shall be maintained to facilitate ease of movement of vehicles and equipment.

5. The subcontractor shall furnish and install road signs and signals, and shall mark and stripe pavements if pavement is provided, as required, for the safe operation of vehicles.

6. Longitudinal and cross drainage facilities including, but not limited to, ditches, structures, pipes and the like shall be furnished and installed by the subcontractor.

B. Endangered Species Protection:

1. Astragalus Wetherilli is found on the south faces of the slopes of the hills adjacent to the proposed haul road as shown in a separate document entitled "Information for Bidders, Vol. II".

2. Astragalus Wetherilli is a plant species of concern to the Colorado Natural Heritage Program, the U.S. Fish and wildlife, and the Endangered Species office. The description of the species is contained in the document

* P.I.D. 06-S-17 
mentioned in B.1 above and the locations are shown on the Subcontract Drawings.

3. The subcontractor shall protect these species from extinction and excessive impacts during construction, operation and maintenance of the haul road.

4. The subcontractor shall, as a minimum, construct a temporary woven wire protective fence at the base of the hilis along the proposed haul road between Highway 13 and the site boundary as shown on the subcontract Drawings.

\subsection{STORAGE OF MATERIALS AND EQUIPMENT}

A. Subcontractor shall make arrangements for exterior storage areas for materials, equipment, and debris. Locations and perimeters of such facilities shall be subject to the approval of the contractor.

B. All operations of the subcontractor, including storage of materials, shall be confined to approved areas. Subcontractor shall be liable for any and all damage caused by him during such use by him of property of the contractor or other parties. Materials shall be stored in accordance with manufacturer's instructions as applicable.

c. Subcontractor shall store construction materials and equipment within boundaries of designated areas. Storage of gasoline or similar fuels shall conform to the requirements specified in Article $\mathrm{SC}-7$ of the special Conditions and section 01560, Article 1.6.B.

\subsection{CONSTRUCTION EQUIPMENT}

A. Subcontractor shall erect, equip, and maintain all construction equipment in accordance with all applicable statutes, laws, ordinances, rules and regulations of the contractor or other authority having jurisdiction.

B. Scaffolding, staging, runways, hoists, barricades, and similar equipment required for performance of the subcontract shall be provided and maintained by the subcontractor. Hoists or similar equipment shall be provided with operators and signals, as required.

c. Subcontractor shall provide, maintain, and remove upon completion of the work, all temporary rigging, scaffolding, hoisting equipment, debris boxes, barricades around openings and excavations, fences, ladders, and all other temporary work, as required for all work hereunder unless otherwise directed by the site Manager.

Document No. 3885-RFL-S-01-00735-04

Issued for Construction-Revision 1

Construction Facilities 
D. Construction equipment and temporary work shall conform to all the requirements of state, County, and local authorities, OSHA, and underwriters which pertain to operation, safety, and fire hazard. Subcontractor shall furnish and install all items necessary for conformity with such requirements, whether or not called for under the separate sections of these Specifications.

E. The Subcontractor shall provide space and suitable lighting for the maintenance of the equipment.

\subsection{TEMPORARY SANITARY FACILITIES}

A. Subcontractor shall provide temporary sanitary facilities for use by all employees and persons engaged in the work, including lower-tier subcontractors, Contractor, DOE, their employees and authorized visitors.

B. Sanitary facilities include enclosed chemical toilets, washing sinks, pipes, tanks and pumping equipment. These facilities shall meet the requirements of local public health standards. Open pit or trench latrines will not be permitted.

C. Chemical toilets and washing sinks shall be provided for use by the subcontractor, his employees and all other workers and suppliers.

D. Contaminated water from the Access control and Laboratory trailers wash sinks, the outside sink and foot wash facilities and from the emergency shower shall be collected to drain into the decontamination sump by a separate piping system. The contents of the sump shall be pumped into the wastewater retention basin or to decontamination washwater recycling system.

E. Sanitary waste from wash sinks and toilets provided in the Contractor's trailers shall be drained to an underground septic tank by a separate piping system, or at the subcontractor's option to existing sanitary sewer system where available. The contents of the underground septic tank, if provided, shall be disposed of offsite as subcontractor's property.

F. During the term of the subcontract, all tanks, including the decontamination sump, shall be kept pumped out at regular intervals to prevent overflow and contamination of the ground, flowing streams or surface drainage.

G. Sanitary facilities shall be located as shown on the subcontract Drawings and as approved by the contractor, and shall be maintained in a sanitary condition during the entire

Document No. 3885-RFL-S-01-00735-04

Issued for Construction-Revision 1 Construction Facilities 
course of the work. Subcontractor shall keep such facilities adequately supplied with toilet paper, paper toweling, paper cups, etc., as required.

H. At completion of the Work, sanitary facilities shall be properly disinfected and the tank and the contents disposed of as required by the contractor.

\subsection{TEMPORARY ELECTRIC POWER}

A. The subcontractor shall provide and maintain during the course and progress of the Work all electrical power and wiring requirements to facilitate the work of all trades and services associated with the work, including power for sprinkler system, decontamination pads, retention basins and all existing facilities and 480 Volt power to the wastewater treatment plants at old and New Rifle and at Estes Gulch. The Rifle processing sites can be served by public service Company of colorado (electricity and gas). The subcontractor shall make arrangements with the applicable serving utility and, except for power at the wastewater treatment plants, shall pay all charges for providing and maintaining electrical service including usage costs at the site. All temporary wiring, feeders, and connections shall be furnished by the subcontractor. Usage costs for power used by the wastewater treatment plants will be paid by the Contractor. The subcontractor shall provide an approved commercial grade sub-meter at each plant for measuring power usage.

B. Routing of temporary conductors, including welding leads shall not create a safety hazard nor interfere with operation and maintenance of existing facilities. Approval from site Manager shall be obtained prior to making connections to existing power panels.

c. All temporary wiring installed by the subcontractor shall be accomplished in accordance with the requirements of the National Fire Protection Association (NFPA) Standards Nos. 70 and $70 E$ (latest edition), using acceptable code materials and equipment.

D. There may be times during the period of the subcontract when the contractor will schedule power outages which will make temporary electrical power unavailable over any of the electrical transmission and distribution systems. Normally, these outages will be scheduled sufficiently in advance to give the subcontractor prior notification; however, due to operational requirements, it may be necessary to "kill" the lines without prior notification. The contractor assumes no liability for interruptions, delays, or inconveniences caused to the subcontractor as a result of

Document No. 3885-RFL-S-01-00735-04

Issued for Construction-Revision 1 Construction Facilities 
such electrical power outages or power failure, scheduled or unscheduled, except that any delay in completion of the work resulting directly from [such power outages shall be deemed a delay due to unforeseeable causes beyond the control and without the fault or negligence of the subcontractor within the meaning of the Article GP-56, DEFAULT, of the General Provisions and the subcontractor shall be entitled to relief in accordance with the provisions of said Article GP-56, provided he gives written notice of such delay in accordance with the requirements thereof.]* There will be no adjustment in the subcontract price due to any such electrical power outage or power failure.

E. Subcontractor shall provide power and lighting to all trailers, and for all work as required, at no extra cost to the Contractor, and as follows:

1. A minimum of $240 / 120 \mathrm{~V}$, 3-phase, $200 \mathrm{~A}$ electric service to all Contractor's trailers.

2. Adequate temporary lighting to all trailers, and for all Work, as required.

3. Yard security lighting to consist of one pole mounted mercury vapor yard light at each office trailer.

4. [Power to the decontamination pads as required.]*

F. Temporary power for the Radon Gas Monitor (RGM) stations and the Air Particulate (AP) Stations and TSP stations: Power provided shall be capable of providing 2-1/2 kW minimum service and shall be $120 \mathrm{~V}$, single phase, 60 cycle. The use of generators or temporary power lines shall be at the subcontractor's option. This power shall be provided and available 30 days prior to contaminated earthmoving activities and maintained for 30 days after completion of the radon barrier cover. Locations of the above stations and availability of power sources are shown on Figures 01500-A1, 01500-A2 and 01500-A3. Temporary power shall be removed at the completion of the subcontract.

[G. The contractor will furnish and the subcontractor shall install a meteorological tower at the Estes Gulch access control area including temporary power.]*

\subsection{TEMPORARY WATER}

A. General:

1. All temporary water for potable and construction use shall be provided by the subcontractor.

* P.I.D. 06-S-17

Document No. 3885-RFL-S-01-00735-04

Issued for Construction-Revision 1 Construction Facilities 
2. Subcontractor shall furnish, install, operate and maintain all equipment, including necessary tanks, piping, hoses, meters, valves, fixtures, and the like, to provide water to various points of usage throughout the site.

[B. Potable Water:

1. Subcontractor shall provide chilled drinking water in bottles from an approved source.

2. Potable water for sanitary uses shall be provided to all Contractor's trailers and access control trailers from an approved source.

3. The subcontractor shall provide an adequate supply of potable (drinking) water in all places of employment. The subcontractor shall comply with 29 CFR 1926.51 and maintain documented evidence that weekly inspections are conducted to assure compliance.]*

c. Construction water: The potential construction water sources are listed below. The subcontractor shall obtain purchasing agreement and/or water rights from the appropriate water jurisdiction or authority. Where alternate water sources are available, the subcontractor may use one or more sources for his need the subcontractor shall be responsible for making all necessary arrangements therefor.

1. Old Rifle site: There is an existing inactive water line in the vicinity of the old Rifle site. (City of Rifle water supply). It is approximately 0.3 miles from the site.

2. New Rifle site: There is an existing active water line in the vicinity of the New Rifle site. (City of Rifle Water supply)

3. Estes Gulch Site: Water sources in the vicinity of the site are: (i) Government Creek and/or Rifle creek, however water from these creeks may be seasonal, (ii) Rifle Gap reservoir which is about 3.5 road miles to the northeast on Highway 325, (iii) the City of Rifle water supply system, and (iv) storm runoff collected in the wastewater retention basin. Use of retention basin water shall be limited to the construction operations in contaminated areas only.

* P.I.D. 06-S-17 
4. [UMETCO water Rights on the colorado River will be available at old and New Rifle sites. It may be that water from the UMTECO rights can not be used at Estes Gulch.]*

5. Wells along Highway 13 beside Government Creek.

[6. Contractor does not warrant that water will be available from the above named sources.]*

\subsection{DECONTAMINATION PADS AND WASHWATER RECYCLING SYSTEM(S)}

A. The subcontractor shall design, furnish, install, operate, maintain, remove and dispose of a [decontamination pad(s) and washwater recycling system(s)]* at each site for:

1. Washing contamination from vehicles, equipment, tools and materials that become contaminated during use in the work.

2. Recycling washwater from wastewater recirculation pond or open tank for reuse as washwater for decontamination [or other uses upon approval of the contractor]*.

3. Furnishing make-up water and emptying the surplus water, when required.

4. Emptying the solids from the sump, as required.

B. The decontamination and [washwater recycling system(s)]* shall, as a minimum, consist of the following facilities furnished and instalied by the subcontractor:

1. Wash system capable of decontaminating vehicles, tools and equipment, as required, for work under the subcontract, consisting of pumps, motors, water tanks, suction and discharge piping, valves, meters, gages, nozzles, etc.

2. A recirculation pond or an open top compartmentized tank.

3. A decontamination pad.

c. Contaminated washwater and sediments shall flow from the decontamination pad by gravity into the pond or open tank. The water from the pond or tank shall be recycled as washwater by a pumping system. The sediment shall be collected and disposed of as contaminated material.

* P.I.D. $06-S-17$ 
D. The subcontractor shall submit his proposed vehicle wash system designs, including calculations, drawings, and equipment list with capacities, to the contractor for review at least 45 days prior to commencement of installation.

E. Construction of decontamination pad at each site shall conform to that shown on the subcontract Drawings.

1. The pad shall be of Portland cement concrete and may be of reinforced or unreinforced design.

2. The pad shall be designed by the subcontractor, and the design shall be submitted to the contractor for review and approval. The pad shall be designed and constructed to handle the largest and heaviest vehicle to be used by the subcontractor, and the pavement section shall be designed, considering site subgrade conditions, to support the heaviest loading anticipated during project construction. The pad size shall be 50 feet by 100 feet and minimum pad thickness shall be 6 inches.

3. The pad shall be designed to drain to the recirculation collection point, without spillage outside the facilities.

4. All joints shall be sealed and the pad shall be maintained in a waterproof condition to eliminate the possibility of washwater draining into the subgrade.

F. Demolition and disposal of decontamination systems shall conform to section 02050.

[G. The subcontractor shall submit his operations plan for each decontamination facility 30 days prior to commencement of hauling operations. The submittal shall include, but not be limited to, the following:

1. Safety.

2. Manpower required.

3. Decontamination of vehicles other than haul units.]*

\subsection{TEMPORARY HEAT}

Subcontractor shall provide, at his own expense, all temporary heat as necessary for the trailers, for proper installation of all work, equipment, and materials, and for the protection of all work and materials, against injury from dampness, cold, and freezing.

* P.I.D. 06-S-17 


\subsection{TEMPORARY TELEPHONE SERVICE}

[The subcontractor shall provide telephone service for his own use. The subcontractor shall provide telephone services to the following trailers for use by the contractor's staff. Monthly usage costs shall be paid by the contractor.

1. One office trailer and laboratory trailer lcoated at Estes Gulch.

2. Phone services shall be installed within thirty days after trailer erection at Estes Gulch.]*

\subsection{TEMPORARY FENCES}

See Sections 02832,02833 and 02835 .

[Text Deleted]*

[1.19 NOT USED]*

\subsection{SHUT-DOWN TIME OF SERVICES}

The subcontractor shall not disconnect or shut down any part of the existing utilities and services, except by express written permission of the contractor. The subcontractor shall submit a schedule of estimated shut-down time in order to obtain such permission, and shall notify all interested parties, utilities, county authorities, etc., as required.

\subsection{MAINTENANCE}

A. Subcontractor shall maintain all temporary facilities and utilities (except for utilities maintained by others such as contractor's telephone service) in good working condition as required by the contractor during the term of the subcontract.

B. Subcontractor's maintenance shall include, but not be limited to, the following:

1. [Access road from State Highway 13 to Estes Gulch disposal site and all temporary roads including access control areas and fencing for the safe and efficient transport of equipment, supplies and personnel.]*

* P.I.D. 06-S-17 
2. Operation and Maintenance of Existing Sprinkler System on the Tailings pile at New Rifle site: The sprinkler system shall be operated to maintain the moisture in the tailings at a frequency as required by the contractor. The system shall be maintained in operating condition at all times. Maintenance will also include draining of the system in cold weather to prevent freezing of the lines. when the old Rifle pile has been disturbed, the subcontractor shall be responsible for its maintenance and moisture conditioning. There is a Government-owned sprinkler system at old Rifle which may be used by the subcontractor. All maintenance and repairs shall be the responsibility of the subcontractor.

c. The subcontractor shall remove from the access and the haul roads and properly dispose of any contaminated material deposited there by his operations. Such removal and cleanup shall be at no additional cost to the contractor.

D. The Subcontractor shall maintain the electrical service connection to the wastewater treatment plant during the term of the subcontract, and remove it at the end of the subcontract.

E. Maintenance of state Highway 13 by Colorado Division of Transportation. The Colorado Division of Transportation will perform all maintenance of the haul route along state Highway 13 in accordance with the terms of Memorandum of Agreement for the Maintenance of State Highways during Remedial Action at the Rifle, Colorado, Uranium Mill Tailings site. The contractor will give the subcontractor advance notice of Colorado Division of Transportation scheduled maintenance operations.]*

\subsection{STATUS AT COMPLETION}

A. Upon completion of the Work, or prior thereto, when so required by the contractor, subcontractor shall:

1. Repair all existing temporary roads improved by the Subcontractor for his convenience including recompacting and resurfacing to at least equal or better conditions existing prior to the start of the subcontract, at no additional cost.

2. kepair the new access road from Highway 13 to the disposal site. Repair work will include recompacting and resurfacing of structural section, and reconstruction of culverts if necessary. obliterate all other new roads constructed as temporary roads.

P.I.D. 06-S-17

Document No. 3885-RFL-S-01-00735-04

Issued for Construction-Revision 1 construction Facilities 
3. Remove and dispose of all construction facilities including all equipment and subcontractor-furnished trailers. Contractor-furnished trailers shall remain in place. Subcontractor shall remove all utility connections, stoops, steps, blocking and ties for all contractor-furnished trailers. Maintenance and subsequent removal of contractor-furnished trailers and utilities disconnection will be by others.

4. Restore the areas occupied by the construction facilities to their near original contours by grading to provide positive drainage and by seeding the area to match surrounding vegetation. Seeding shall conform to section 02935.

5. All temporary facilities removed by the subcontractor shall be disposed of offsite by the subcontractor as his property.

PART 2 - PRODUCTS

(Not Used)

PART 3 - EXECUTION

(Not Used)

PART 4 - MEASUREMENT AND PAYMENT

4. 1 MEASUREMENT

A. Measurement for payment for the following items will be by their Iump sum basis:

1. Temporary offices

2. Temporary Roads and Parking Areas

3. Temporary sanitary Facilities

4. Temporary Electric Power

5. Temporary Water

6. Decontamination Washwater Recycling System(s) at Estes Gulch Disposal site 
7. Decontamination Washwater Recycling system(s) at old Rifle Processing Site

8. Decontamination Washwater Recycling System(s) at New Rifle Processing Site

[Text Deleted]*

B. Measurement for payment for janitorial services will be by the number of months of janitorial services actually provided. Month will be a calendar month.

c. Measurement for payment for snow removal services will be by the number of hours of snow removal services actually provided.

D. Separate measurement for payment will not be made for any other item of work specified in this section.

\subsection{PAYMENT}

A. Payment for [Items 1 through 8] * of Article 4.1.A above will be by their applicable lump sum prices quoted therefor in the Bid Schedule.

B. Payment for janitorial services will be by the unit price per month quoted therefor in the Bid schedule.

c. Payment for snow removal services will be by the unit price per hour quoted therefor in the Bid Schedule.

D. The prices quoted shall include full compensation for furnishing all labor, materials, equipment, tools, accessories, and incidentals, and for performing all work including designing, fabricating, installing/constructing, operating, maintaining, removing and disposal of facilities and providing specified services as required, through the term of the subcontract.

E. Separate payment will not be made for any other item of work specified in this section. Full compensation for such work will be considered to be included in the applicable related items of Work under the subcontract or in the Bid schedule item for Mobilization.

\section{END OF SECTION 01500}

* P.I.D. 06-S-17

Document No. 3885-RFL-S-01-00735-04

Issued for Construction-Revision 1

Construction Facilities 
Power shall be provided to these locations by the subcontractor for operation during Phase II work and until 30 days after completion of the subcontract.

[1. Southwest perimeter boundary of old Rifle processing site. This location has not been established. Power shall be furnished upon location of this station in an area designated by the site Manager.

2. Estes Gulch: Location will be at the access trailer. Power supply needs to be established.]*

* P.I.D. 06-S-17

Document No. 3885-RFL-S-01-00735-03 
OLD AND NEW RIFLE SITES

ENVIRONMENTAL MONITORING STATIONS

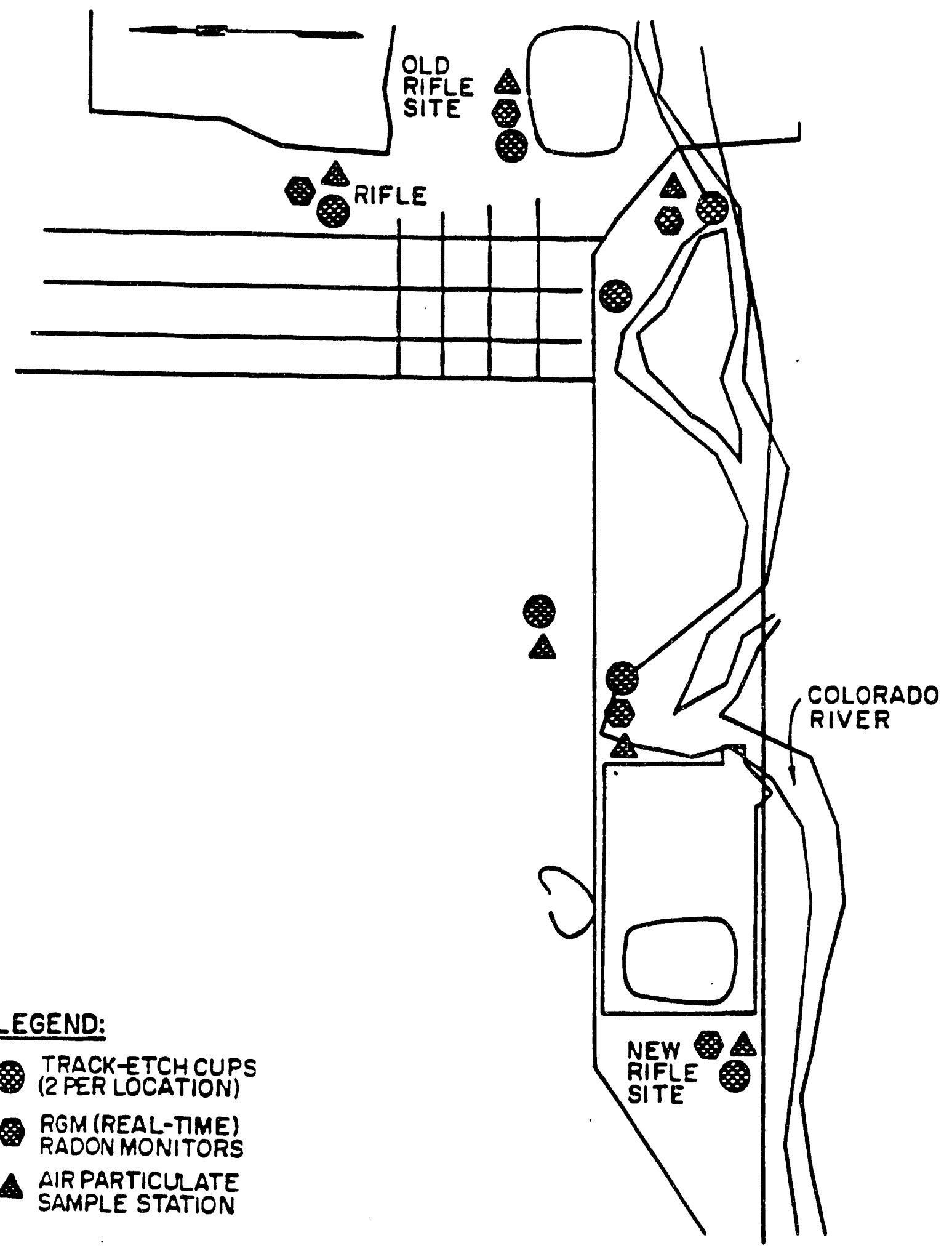

$01500-42$ 
ESTES GULCH DISPOSAL SITE

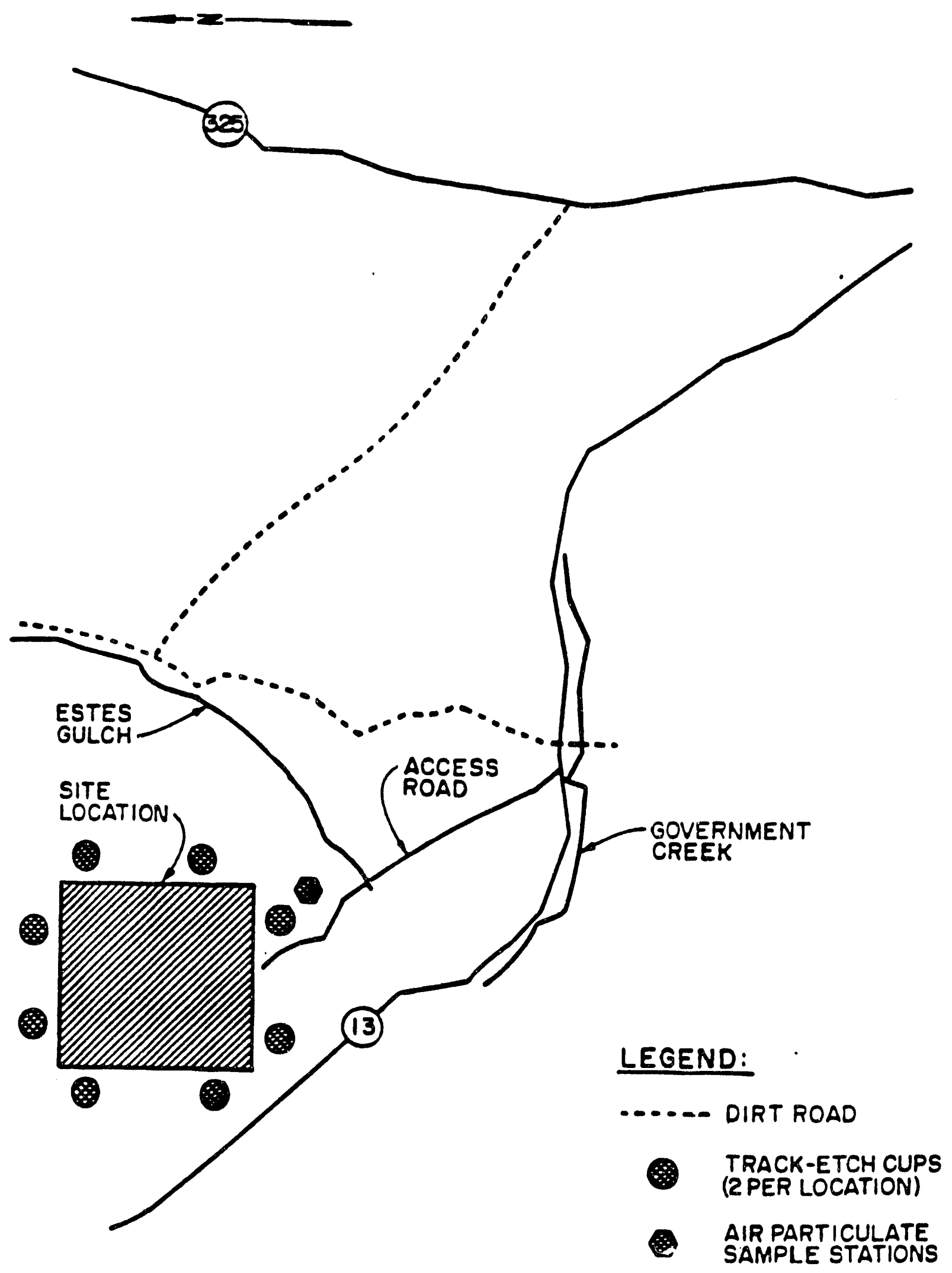




\section{SECTION 01560 \\ TEMPORARY CONTROLS}

PART 1 - GENERAL

1.1 SCOPE

A. This specification section covers the requirement for temporary controls required during the construction of the temporary and permanent works. Temporary controls shall include related equipment, facilities, and incidentals.

B. Temporary controls shall include, but not be limited to, the following:

1. Dust Control (Nuisance and Radiological)

2. Noise Control

3. Pollution Control

4. Water Control

5. Access, Traffic and Safety Controls

6. Protection of Exposed Surfaces

c. The subcontractor shall be responsible for furnishing, installing, constructing, operating, maintaining, removing and disposing of the controls as shown on the subcontract Drawings, as specified in this specification, and as required by the contractor for the completion of the Work under the subcontract.

D. All such temporary controls shall be located as shown on the Subcontract Drawings and as directed by the contractor, and maintained in clean, safe and sanitary condition at all times until completion of the subcontract.

E. Upon completion of the subcontract, the temporary controls shall be left in the status specified in Article 1.11 of this section.

F. The requirements specified herein are in addition to any requirements specified elsewhere in the subcontract Documents. Temporary controls shall meet the requirements for all-weather service.

G. All land disturbances related to the temporary controls shall be minimized to the greatest extent possible and the land restored to the extent reasonable and practical, to its original contours by grading to provide positive drainage and by seeding the area as specified in section 02935. 
1.2 RELATED WORK
A. Section 00800 - Special Conditions: Noise Control
B. Section 01019 - Mobilization: Payment
c. Section 01500 - Construction Facilities
D. Section 02141 - Dewatering and Drainage
E. Section 02200 - Earthwork: Site Restoration
F. Section 02935 - Seeding

\subsection{APPLICABLE PUBLICATIONS}

A. The Publications listed below form a part of this specification to the extent referenced. The publications are referred to in the text by the basic designation only:

1. UMTRA Project Construction Environment, Safety and Health Management Program (MK-UMTRA-4)

2. Colorado Highway Department:

"Standard Specifications", as applicable.

3. Uniform Building Code (UBC):

1988 Edition, applicable Chapters and sections.

4. National Fire Protection Association (NFPA), as applicable.

5. American Society for Testing and Materials (ASTM):

D751-79 Methods for Testing Coated Fabrics

D1682-64 Standard Test Methods for Breaking Load and Elongation of Textile Fabrics

6. Occupational Safety and Health Administration, Standards as applicable.

7. National Electric Code, Standards as applicable.

8. [DOE Order 5000.3A, DOE Order 5480.11 (Radiation Protection for Occupational workers), and other applicable DOE orders.]*

* P.I.D. 06-S-17

Document No. 3885-RFL-S-01-02083-03

Issued for Construction-Revision 1 
B. All required facilities, equipment and utilities shall also be constructed/installed, maintained and operated in accordance with applicable Federal, state, county, and Utility laws, rules, and regulations. Notwithstanding contrary provisions of General Provisions, General Conditions and Special Conditions, nothing in the subcontract Drawings and specifications shall be construed to permit work not conforming to such laws, rules and regulations.

\subsection{DUST CONTROL}

A. The Subcontractor shall be responsible for providing adequate dust control measures during the term of the subcontract as required by the contractor and the state Air Emissions Permits.

B. [Dust control shall consist of furnishing water supply, required equipment, additives, accessories and incidentals, and carrying out proper and efficient measures wherever and as often as necessary to reduce dust nuisance, and to prevent dust originating from construction operations or from natural causes on all sites, as required by the contractor. Dust shall be controlled.]*

c. Water shall be applied by means of pressure-type distributors or pipe lines equipped with a spray system or hoses with nozzles that will ensure a uniform application of water.

D. All equipment used for the application of water shall be equipped with a positive means of shut-off.

E. [All equipment shall be in good operating condition for applying water on the project at all times.]*

F. To conserve water, the subcontractor may use chemical additives in dust control water. If such additives are used, furnishing and applying the additives shall be at no additional expense to the contractor.

G. The use, location of application, and the amount and type of additives proposed for use by the subcontractor shall be subject to approval by the contractor and appropriate regulatory agencies.

* P.I.D. $06-S-17$

Document No. 3885-RFL-S-01-02083-03

Issued for Construction-Revision 1

Temporary Controls 
H. The primary sources of water for dust control in contaminated areas at the sites will be recycled water or water from tailings and subsoil dewatering to the extent feasible. When these sources are judged inadequate or unacceptable the subcontractor may, with the contractor's approval, use water from an alternate source.

I. The source of water for dust control in non-radiologically contaminated areas shall be free of contamination.

J. Dust in parking areas shall also be controlled.

K. The subcontractor shall only apply the amount of water necessary for dust control and compaction. Excess water shall not be applied to tailings placed in the disposal cell.

1.5 NOISE CONTROL

See Section 00800, Article SC-7, Paragraph M.

\subsection{POLLUTION CONTROL}

A. Pollution of Waterways: The Subcontractor's construction and related activities shall be performed by methods that prevent entrance or accidental spillage of solid or liquid matter, contaminants, debris and other objectionable pollutants and wastes into streams, watercourses, flowing or dry, and underground water sources. Such pollutants and wastes will include, but will not be restricted to refuse, earth and earth products, garbage, cement, concrete, sewage effluent, industrial waste, radioactive substances, hazardous chemicals, oil and other petroleum products, aggregate processing tailings, and mineral salts. Pollutants and wastes shall be disposed of in accordance with applicable permit provisions or in a manner acceptable to and approved by the contractor.

B. Storage and Disposal of Petroleum Products:

1. Petroleum products covered by this section include gasoline, diesel fuel, lubricants, heating oils, and refined and used oil. During project construction, all petroleum products shall be stored in such a way as to prevent contamination of all ground and surface waters.

2. Storage facilities shall conform to the requirements of Construction Environment, Safety and Health Management Program specified in Article $\mathrm{SC}-7$ of the special Conditions.

Document No. 3885-RFL-S-01-02083-03

Issued for Construction-Revision 1

$R P L=P H=I I$ Temporary Controls 
3. Lubricating oil: Lubricating oil may be brought into the project area in steel drums or other means, as the subcontractor elects. If the total volume of stored oil is greater than 1320 gallons, then the subcontractor shall provide secondary containment facilities in accordance with EPA regulations contained in the code of Federal Regulations 40 CFR 112. Used lubricating oil shall be stored in steel drums, or other approved means, and shall be returned to the supplier for disposal. It shall not be burned or otherwise disposed of at the project area.

4. If the total volume of stored petroleum products is greater than 1320 gallons and these products are stored above ground, the Subcontractor shall prepare a spill Prevention control and Countermeasure Plan in accordance with applicable EPA and state regulations.

[5. The subcontractor shall submit for approval by the Contractor a waste minimization and recycling plan for material generated on-site including, but not limited to, used oil, used anti-freeze, used fuels, used oil filters, used containers of maintenance products (e.g. paint cans), oily rags, and petroleum product contaminated soils, prior to the generation of any such materials. This plan shall address all points of generation surveillance, handling, recycling, record keeping, and other pertinent items.]*

c. The following environmental pollution control measures shall be adopted by the subcontractor for the trucks hauling contaminated materials on public roads to prevent the spread of radioactive contamination in uncontaminated areas:

1. Trucks shall be equipped with leakproof seals and locking devices on dump gates or other approved means to prevent leakage of contaminated material onto roadways.

2. In addition to the above mentioned provisions, the Subcontractor shall take the following additional measures:

a. [Trucks shall be totally enclosed by a system that structurally covers all surfaces or a tarpaulin system that covers the top surface completely with the sides being structurally contained.]*

b. [Prior to travel on offsite roadways or beyond the contaminated site area, trucks shall be decontaminated by washing with water of all contamination as determined by the contractor.]*

* P.I.D. 06-S-17

Document No. 3885-RFL-S-01-02083-03

Issued for Construction-Revision 1 Temporary controls 
3. Health Physics personnel employed by the Contractor will routinely check trucks for residual contamination prior to release from contaminated areas.

\section{[1.7 WATER CONTROL}

A. When water hose usage is required on the project, the water hoses shall be located inside the site areas such that any spilis which might be contaminated are contained within the site areas. When it is not feasible to locate hoses inside any site perimeter such that any potentially contaminated spill can be contained inside the site boundary, berms shall be constructed so that any spill will be contained inside the site boundary.

B. For other water control requirements, see section 02141, Dewatering and Drainage.]*

1.8 ACCESS, TRAFFIC AND SAFETY CONTROLS

A. Access Control:

1. Private, personal or agency vehicles not used for authorized construction purposes will not be allowed in the controlled site areas.

2. Parking of private, personal or agency vehicles shall be in a restricted area outside of the controlled site areas as designated by the site Manager or his representative.

B. Traffic and safety Controls:

1. The subcontractor shall post construction areas and roads with traffic control signs or devices used for protection of workmen, the public and equipment. The signs or devices shall conform to the American National standards Institute, Manual on Uniform Traffic Control Devices for Streets and Highways, and the latest revision of the Colorado supplement thereto.

2. Signs or traffic control devices shall be removed or covered as soon as they have served their purpose. It is particularly important to remove any markings on road surfaces which under conditions of poor visibility could cause a driver to turn off the road or into traffic moving in the opposite direction.

* P.I.D. $06-S-17$ 
3. Barricades for protection of employees shall conform to the portions of the American National standards Institute, Manual on Uniform Traffic Control Devices for streets and Highways, relating to barricades.

4. Flag persons, properly equipped with International orange protective clothing and flags, shall be provided at all such times, as necessary, to direct or divert pedestrian or vehicular traffic. [At the railroad crossing and during mowing operations along the railroad right-of-way near the New Rifle site, ]* a full-time flagperson will be posted by the Denver Rio Grande and Western Railway Company during truck transport operations. The subcontractor shall reimburse the railroad company for the cost of the flagperson. A full-time flagperson shall be posted by the subcontractor at the old Rifle site during the construction of the slurry wall. Separate payment will not be made to the subcontractor for posting of a flagperson.

5. Pursuant to Article GP-51 of General Provisions, Section GC-3C.1.a of General Conditions, the Subcontractor shall construct and maintain fences, planking, barricades, lights, shoring, and warning signs as required by local authorities and Federal and State safety ordinances, and as required, to protect the contractor's property from injury or loss and as necessary for the protection of the public, and provide walks around any obstructions made in a public place for carrying on the work covered in this subcontract. All such protection shall be left in place and maintained until removal is authorized.

6. Permanent highway striping and signing at the intersection of Highway 13 and the Estes Gulch access road will be done by the [Colorado Division of Transportation]*.

[7. The subcontractor shall keep all brush and grass mowed for approximately 1,000 feet from the New Rifle site access west along the railroad and state Highways 6 and 24 right-of-ways.

8. The subcontractor shall remove and dispose of all trees located at the north site boundary of the old Rifle site and State Highways 6 and 24 prior to any construction activities.]* 
[9.]* In addition, the subcontractor shall guard and protect all workers, pedestrians, and the public from excavations, blasting operations, construction equipment, all obstructions, and other dangerous items or areas by means of adequate railings, guard rails, temporary walks, barricades, warning signs, sirens, directional signs, overhead protection, planking, decking, danger lights, etc.

[10. Speed limit through Railroad Avenue and State Highway 13 intersection shall be a maximum of $30 \mathrm{mph}$ for all project vehicles.

11. During school busing hours at the intersection of Wamsley Elementary School access road and State Highway 13, the speed limit shall be a maximum of $35 \mathrm{mph}$ for all project vehicles.

12. The subcontractor shall submit a detailed traffic plan for all sites, prior to hauling activities, for Contractor approval.]*

1.9 PROTECTION OF EXPOSED SURFACES

See Section 02200, Article 3.1.A.

\subsection{MAINTENANCE}

Subcontractor shall maintain all temporary controls in good working conditions during the term of the subcontract for the safe and efficient transport of equipment and supplies, and construction of permanent works, as required by the contractor.

\subsection{STATUS AT COMPLETION}

A. Upon completion of the work, or prior thereto, when so required by the contractor, subcontractor shall:

1. Remove all temporary controls as required by the contractor.

2. Restore and seed disturbed areas as specified in sections 02200 and 02935 .

* P.I.D. 06-S-17

Document No. 3885-RFL-S-01-02083-03

Issued for Construction-Revision 1 
PART 2 - PRODUCTS

(ivot Used)

PART 3 - EXECUTION

(Not Used)

\section{PART 4 - MEASUREMENT AND PAYMENT}

\subsection{MEASUREMENT}

separate measurement for payment will not be made for work specified in this Section.

4.2 PAYMENT

Separate payment will not be made for work specified in this section. [Payment for such work will be considered to be included in the applicable related items of work specified elsewhere in the subcontract Document or incidental to the subcontract. ]*

END OF SECTION 01560

*P.I.D. 06-S-17

Document No. 3885-RFL-S-01-02083-03 


\section{SECFION 01561}

\section{CONSTRUCTION CLEANING}

\section{PART 1 - GENERAI}

\subsection{SCOPE}

A. This specification section covers furnishing of all labor, materials, equipment, and services, and performing all operations necessary for, and properly incidental to, cleanup during construction and final cleaning of the site, prior to acceptance of the Project by the contractor as specified herein and in other sections when specified.

B. The requirements specified in this section are supplemental to the requirements specified elsewhere in the subcontract Documents.

1.2 WORK NOT INCLUDED

Chemical, Toxic or Hazardous Waste

¿.3 RELATED WORK

A. Article GC-ID - General Conditions

B. Section 00800 - Special Conditions: Definitions

c. Section 02081 - [Asbestos, Hazardous and Non-Hazardous Materials]*

D. Section 02110 - Site clearing

E. Section 02200 - Earthwork

\subsection{GENERAL}

A. It is required that the entire site be kept in a neat and orderly condition, and the contractor or his representative may, at any time during construction, order a general cleanup of the site as a part of the work under this section.

B. Subcontractor shall dispose of waste, trash, and debris in a safe, acceptable manner, in accordance with applicable laws and ordinances and as prescribed by authorities having jurisdiction. No waste material and debris shall be buried on the site. Burning of trash and debris on the site will not be permitted.

* Revision 
c. Location of a dump for trash and debris and the length of haul to such a location are the subcontractor's responsibility.

\subsection{CLEANUP DURING CONSTRUCTION}

A. Cleanup: The subcontractor will be required to clean up construction work areas including all trailers, parking and storage areas and dispose of waste material. Cleanup of construction work areas will be required on a daily basis. At the close of each day's work all small quantities of waste and debris resulting from construction activities shall be gathered up and disposed of as designated in paragraph $B$ below. Waste and debris shall not be allowed to accumulate in such quantities as to create an unsightly appearance, or safety or fire hazard, nor shall it interfere in any way with free access to, and operation of existing facilities.

B. Waste Disposal:

1. General: Material determined to be waste will be tested for radioactive contamination prior to removal from the construction site. Testing will be performed by the Contractor at no cost to the subcontractor to classify the waste into the following two categories for disposal purposes:

a. Uncontaminated Waste: The subcontractor shall provide suitable receptacles for all construction office waste material such as wrapping paper, discarded containers, scrap lumber, scrap metals, etc. Other uncontaminated waste including construction office waste shall be disposed of offsite as subcontractor's property in a safe, acceptable manner, in accordance with the applicable laws and ordinances and as prescribed by authorities having jurisdiction. No waste material and debris shall be buried on the site. The Subcontractor shall be responsible for the location of dump for trash and debris, length of haul, and disposal costs.

b. Contaminated Waste: Waste materials identified as contaminated materials defined in Article SC-1 and materials resulting from demolition operations and demolished materials stockpiled on site shall be disposed of in the construction of the tailings embankment as specified in section 02200 . 


\subsection{FINAL SITE CLEANUP}

A. Prior to final inspection, the entire site shall be thoroughly cleaned and shall be put into a neat, acceptable condition. All construction waste and unused materials, dunnage, loose rock and stones, excess earth, and debris of any description resulting from the work shall be removed from the entire site.

[Text Deleted]*

[B.]* All construction areas shall be thoroughly cleaned to the satisfaction of the Contractor prior to final acceptance of the completed subcontract.

\section{PART 2 - PRODUCTS}

(Not Used)

PART 3 - EXECUTION

(Not Used)

\section{PART 4 - MEASUREMENT AND PAYMENT}

\subsection{MEASUREMENT AND PAYMENT}

Separate measurement or payment will not be made for work required under this section. All costs in connection with the work specified herein will be considered incidental to the subcontract.

END OF SECTION 01561

* Revision 
Division 2

Sitework 


\section{[SECTION 02010]*}

\section{SUBSURFACE INVESTIGATIONS}

\section{PART 1 - GENERAL}

\subsection{SCOPE}

A. This specification section describes the requirements for subsurface radiological and geotechnical investigation work to be performed by the subcontractor at the processing site. The investigations shall include, but not be limited to, the following:

1. Excavation of test pits.

2. Filling and leveling of test pits.

3. Site restoration including removal or disposal of equipment, materials and debris as required by the contractor.

B. The subcontractor shall furnish all labor, equipment, supplies, materials, and qualified supervision and shall perform all operations, unless stated herein, in connection with the work specified above.

c. The subcontractor shall be responsibile for maintaining stability of the tailings pile.

1.2 WORK NOT INCLUDED

A. The radiological field survey, monitoring and testing will be performed by the contractor.

B. The laboratory testing to determine radiological characteristics of tailings will be performed by the Contractor.

1.3 RELATED WORK

A. Special conditions

B. 01052 - Layout of Work and Surveys

C. 02090 - Sealing of Abandoned Wells

D. 01300 - submittals

* P.I.D. 06-S-17 


\subsection{APPLICABLE PUBLICATIONS}

A. The Publications listed below form a part of this specification to the extent referenced. The Publications are referred to in the text by the basic designation only:

1. American Society for Testing and Materials (ASTM):

D2488-80 Practice for Description and Identification of Soils (Visual-Manual Procedure)

\subsection{SUBMITTALS}

A. Pursuant to the provisions of section 01300, and thirty days prior to the start of any tests, the subcontractor shall submit to the contractor for review three sets of the following submittals:

1. Subsurface investigation operations plan describing precautions to be taken to maintain stability of the tailing piles during performance of investigation work.

\subsection{EXISTING CONDITIONS}

A. The tailings piles include low density, saturated slimes, in some cases with water content in excess of 30 percent by weight.

B. The materials under the tailings piles consist of slimes, sand slimes and leaching sands from previous operations.

\section{PART 2 - PRODUCTS}

(Not Used)

\section{PART 3 - EXECUTION}

\subsection{EXCAVATION OF TEST PITS}

\section{A. General:}

1. Test pits shall be excavated at locations as directed by the contractor during construction operations. The number and lcoation of the test pits will be determined by the contractor. 
2. The subcontractor shall provide a qualified operator and a backhoe with appropriate power and capability to excavate the test pits to the dimensions specified herein.

3. The test pits shall be excavated to a maximum depth of approximately 20 feet, or to the soil rock interface if rock is encountered, or as designated by the contractor.

B. Sampling and Field Records:

1. Under direction of the Contractor's representative, the Subcontractor shall provide a qualified field engineer to log the test pits and to obtain samples as required by the Contractor. At least one bulk sample shall be taken for each type of soil material encountered in each test pit. The exact number of bulk samples will be determined by the contractor in the field during the investigation. Under direction of the Contractor's representative, each material encountered shall be identified by a qualified geotechnical engineer and described according to the Unified Soils Classification System per ASTM D2488.

2. Logs shall be kept by the Subcontractor for each test pit and shall include the following information:

a. Test pit number.

b. Date of excavation.

c. Equipment used.

d. Name of person recording log.

e. Sketched cross-section.

f. Sketched location of test pit.

g. Approximate ground elevation at top of test pit.

h. Depth at the top of each different material penetrated.

i. Depth at the bottom of the pit.

$j$. Water level encountered and rate of entry into pit.

k. Material other than rock shall be classified according to type, color, moisture content (dry, damp, moist, wet), relative density or stiffness, gradation, angularity and plasticity. 
1. Rock shall be classified according to type, degree of hardness, weathering and fractures.

3. Bulk samples from test pits shall not be less than 75 pounds. Bulk samples shall be placed in durable bags and tagged, inside and out, with the date, test pit number, identification number, and depth of the sample. If more than one bag is used, the tag will state "Bag one of two", etc. A jar sample will also be taken with the bulk sample and the lid shall be sealed with paraffin to avoid moisture loss. This jar shall be marked with the date, test pit number, and depth of the sample.

\subsection{CLEANUP}

Upon completion of work and acceptance by the contractor, the subcontractor shall backfill and level each test pit. The subcontractor shall remove from the site all equipment, tools, supplies, and other waste materials such as metal cans, papers, and bags imported to the site by the subcontractor during the field investigation and leave the site in a neat, presentable condition subject to the Contractor's approval.

\subsection{SUBMITTAL OF FIELD LOGS AND RECORDS}

Two copies each of the field logs of borings and test pits and driller's report shall be sent to the contractor within seven days of the completion of the field investigation work at the following address:
M-K Environmental Services
180 Howard Street
San Francisco, CA 94105
Attention: Mr. Grant Cherrington

\section{PART 4 - MEASUREMENT AND PAYMENT}

\subsection{MEASUREMENT}

A. Measurement for payment for excavation of test pits will be by the number of hours of backhoe operation to excavate the test pits.

B. No separate measurement for payment will be made for standby time during test pit excavation or for cleanup work specified in this section.

Document No. 3885-RFL-S-01-04252-00

Issued for Construction-Revision 0 Subsurface Investigations 


\subsection{PAYMENT}

A. Payment for excavation of test pits will be by the unit price per hour of backhoe operation quoted therefor in the Bid Schedule. Price quoted shall include full compensation for furnishing all equipment, tools, acccessories and for performing the work of excavation including preparation and submission of field records.

B. No separate payment will be made for standby time during test pit excavation or for cleanup work specified in this section. All costs in connection with such work shall be considered incidental to the related item of work.

END OF SECTION 02010

Document No. 3885-RFL-S-01-04252-00 


\section{SECTION 02050}

\section{DEMOLITION}

\section{PART 1 - GENERAL}

\subsection{SCOPE}

A. This specification section describes the requirements for the demolition of structures and disposal of demolished materials and debris as specified in this section.

B. Structures and facilities to be demolished include the following:

1. Existing structures/Facilities:

a. Drainage manhole at old Rifle Processing site.

b. Woven wire fences at the New Rifle decontamination pad.

c. Chain link fence and associated gates from the access control area at the processing sites.

d. 36-inch diameter buried RCP at old Rifle Processing site.

e. Power line with poles at old Rifle and New Rifle Processing Sites.

f. Sprinkler system on the tailings pile at New Rifle Processing Site.

g. Decontamination pads and sumps at the old Rifle and New Rifle Processing sites.

h. Monitor wells in accordance with Table 02050-B.

i. Retention basins at old Rifle and New Rifle Processing sites.

j. Ditch crossings and 24-inch diameter culverts, one at New Rifle and three at old Rifle.

k. Contaminated water treatment plant pads at old Rifle and New Rifle Processing sites.

1. Membrane liners from ditches, retention basins, spillways, washwater collection sumps, and washwater

Document No. 3885-RFL-S-01-00736-04

Issued for Construction-Revision 1 
recirculation ponds at old Rifle and New Rifle Processing sites.

m. Motor vehicle tires stockpiled at the old Rifle and New Rifle Processing sites and those scattered in various locations on the sites.

n. [Concrete foundations and slabs left in place at old Rifle]* Processing site at the termination of Phase I subcontract.

o. [Any rubble, concrete, debris, slabs, pipes, steel, poles, tires, etc., buried in the tailings piles at old or New Rifle.]*

p. All utilities left in place at the Processing sites at the termination of Phase I subcontract.

2. Structures installed/constructed under this subcontract:

a. [Washwater recirculating system including piping, tanks, and pond liners at Estes Gulch Site, and New and old Rifle sites.]*

b. Membrane liners from ditches, retention basins, spillways, washwater collection sumps, and washwater recirculation ponds at Estes Gulch Site.

c. [Decontamination pad at Estes Gulch Site, and New and Old Rifle sites.]*

[ Text Deleted]*

\subsection{WORK NOT INCLUDED}

A. Disposal of existing stockpiles of demolished materials and debris is not included in the scope of work of this section. Disposal of existing stockpiles of demolished materials and debris shall be as specified in section 02200 .

[Text Deleted]*

* P.I.D. 06-S-17

Document No. 3885-RFL-S-01-00736-04

Issued for Construction-Revision 1 
1.3 RELATED WORK

A. Section 00800 - Special Conditions: Articles SC-7 and SC-8

B. Section 01300 - submittals

C. Section 01500 - Construction Facilities

D. Section 01560 - Temporary Controls

E. Section 01561 - Construction cleaning

F. Section 02200 - Earthwork: Disposal of Demolished Materials and Debris and Grading Areas

G. Section 02771 - Membrane Liner

H. Section 03000 - Concrete Work: Plugging of Steel Casing Pipe and constructing a concrete sump

\subsection{DEFINITIONS}

Demolition includes complete dismantling, cutting and breaking up of structures, including all solid contents and associated services and utility lines including their foundations and below grade slabs and footings.

\subsection{STRUCTURES TO BE DEMOLISHED}

A. A brief description, type of construction and approximate dimensions of the existing structures to be demolished or abandoned are listed in Table 02050-A and identified on the subcontract Drawings.

B. The structures and facilities installed/constructed under this subcontract are specified under various specification sections of this subcontract and are shown on the subcontract Drawings. [Al] temporary structures and facilities built at the sites shall be demolished and disposed of.]*

\subsection{SUBMITTALS}

A. General submittal requirements are specified in section 01300 .

B. Ten days prior to the start of Work, the Subcontractor shall submit to the contractor, for review, a demolition plan including the following:

1. Methods of demolition to be used.

2. Schedule showing dates and structures to be demolished.

3. List of equipment to be used.

* P.I.D. 06-S-17

Document No. 3885-RFL-S-01-00736-04

Issued for Construction-Revision 1 


\section{TABLE 02050-A}

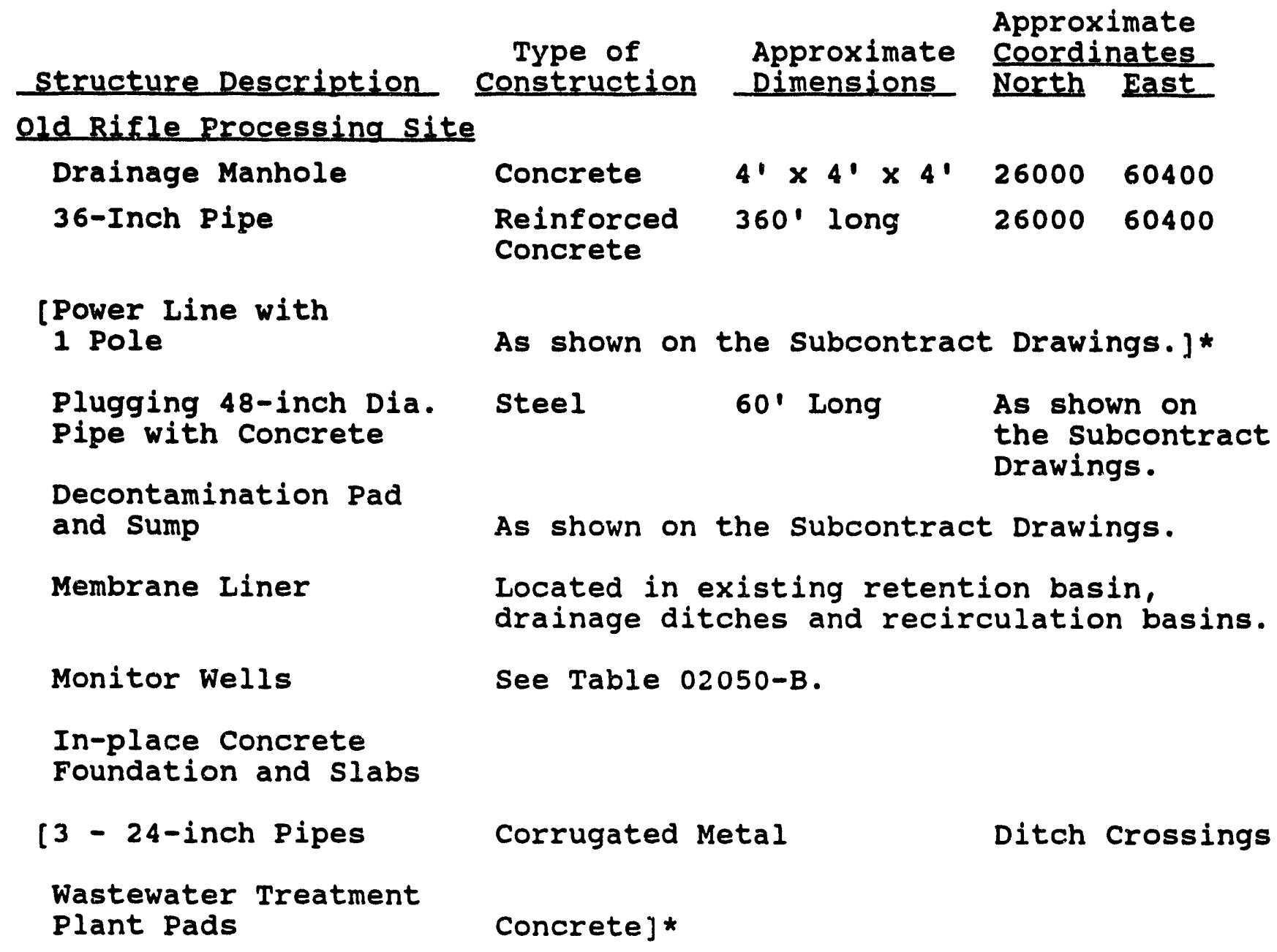

New Rifle Processing Site

Woven Wire Fences

Fencing (Access Con-

trol Area)

Double Leaf Swing Gate

(Access Control Area)

Gate

Power Line with

17 Poles

* P.I.D. 06-S-17
160 feet at decontamination pad.

Metal-Chain 690' N/A N/A

Link

Metal-Chain $40^{\prime}, 30^{\circ} \quad$ N/A N/A

Link

Metal-Chain $3^{\prime} \times 6^{\prime}$

Link

As shown on the subcontract Drawings. 
TABLE 02050-A (Cont'd.)

\begin{tabular}{|c|c|}
\hline structure Description & $\begin{array}{ccc}\text { Type of } & \text { Approximate } & \begin{array}{c}\text { Approximate } \\
\text { Coordinates }\end{array} \\
\text { Construction } & \begin{array}{c}\text { Dimensions } \\
\text { Dorth East }\end{array} \\
\end{array}$ \\
\hline Sprinkler system & 19,000 lineal feet of $1 "$ to $6 "$ dia. pipe. \\
\hline $\begin{array}{l}\text { Decontamination Pads } \\
\text { and Sumps }\end{array}$ & As shown on the subcontract Drawings. \\
\hline Membrane Liner & $\begin{array}{l}\text { Located in existing retention basin, } \\
\text { drainage ditches and recirculation basin. }\end{array}$ \\
\hline Motor Vehicle Tires & $\begin{array}{l}\text { Stockpiled on site. Approximately } \\
\text { shredded, } 8 \text { not shredded. }\end{array}$ \\
\hline [Monitor well & See Table 02050-B. \\
\hline 1-24-inch Pipe & Corrugated Metal \\
\hline $\begin{array}{l}\text { Wastewater Treatment } \\
\text { Plant Pads }\end{array}$ & Conc \\
\hline 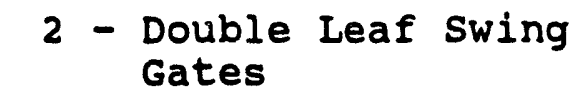 & $\begin{array}{l}\text { (1 Gate to be Installed per } \\
\text { RFL-PS-10-0714, Note } 4 .)]^{*}\end{array}$ \\
\hline
\end{tabular}

* P.I.D. 06-S-17 
WELLS TO BE REMOVED AND DEMOLISHED

\section{NEW RIFLE PROCESSING SITE}

We11

No.

586
Coordinates

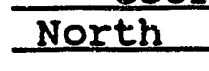

23612.9
Casing

Diameter

(inch)

4

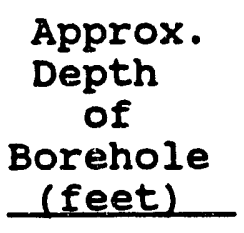

61

OLD RIFLE PROCESSING SITE

\begin{tabular}{|c|c|c|c|c|}
\hline \multirow{2}{*}{$\begin{array}{l}\text { Well } \\
\text { No. }\end{array}$} & \multicolumn{2}{|c|}{ coordinates } & \multirow{2}{*}{$\begin{array}{c}\text { Casing } \\
\text { Diameter } \\
\text { (inch) }\end{array}$} & \multirow{2}{*}{$\begin{array}{c}\text { of } \\
\text { Borehole } \\
\text { (feet) }\end{array}$} \\
\hline & North & East & & \\
\hline 581 & 25859.67 & 59739.01 & 4 & 31 \\
\hline 582 & 25865.73 & 59749.59 & 4 & 21 \\
\hline 583 & 25653.45 & 59749.05 & 4 & 26 \\
\hline 593 & 26107.31 & 59951.93 & 2 & 27 \\
\hline 594 & 26066.71 & 59686.07 & 2 & 27 \\
\hline 595 & 25798.81 & 59948.87 & 2 & 23 \\
\hline 596 & 25613.6 & 59506.5 & 2 & 27 \\
\hline
\end{tabular}

\section{PART 2 - PRODUCTS}

(Not Used)

\section{PART 3 - EXECUTION}

\subsection{DEMOLITION}

A. During the execution of this subcontract, if unidentified waste material is suspected or encountered, the site Manager shall be immediately notified for identification and subsequent disposition.

Document No. 3885-RFL-S-01-00736-04

Issued for Construction-Revision 1 
B. Locations of structures to be demolished are shown on the Subcontract Drawings; however, the subcontract Drawings do not show the locations of all foundations, rubble and debris, concrete pads, and the like, all of which are required to be demolished and removed within the boundaries of the project sites. [Portions of buried concrete foundations exist at old Rifle site.]* If underground structures, including but not limited to, slabs, foundations and abandoned communication duct banks that are not shown on the Subcontract Drawings, or not visible from the surface, or not foreseen by the subcontractor, are encountered, they may be left in-place if all of the following conditions are met:

1. If the concrete is decontaminated, and if soil is not contaminated below it;

2. If the top of the concrete is at least 2 feet below finish grade, and;

3. If the concrete is not shown on the subcontract Drawings and was not visible from the surface at the time of subcontract award.

c. Pollution Controls:

1. Water sprinkling, temporary enclosures, and other contractorapproved methods shali be used to limit the amount of airborne dust and dirt to the lowest practical level. Demolition work shall comply with governing regulations pertaining to environmental protection.

2. Water shall not be used if it is likely to create hazardous or objectionable conditions such as ice, flooding, or pollution. An approved water-based biodegradable wetting agent (surfactant) such as Dupont "Duponol WAQ" or equal shall be used to reduce the quantity of water required.

D. Demolition:

1. Permit requirements are specified in Article sc-11 of the Special conditions.

2. Foundations and other structures shall be demolished by methods required to complete the work in accordance with governing regulations.

3. Pieces of wood, concrete, and masonry shall be cut or broken up to be no greater than 3 feet in any dimension.

* P.I.D. 06-S-17

Document No. 3885-RFL-S-01-00736-04

Issued for Construction-Revision 1 
4. Structural steel members and other long items shall be cut or broken up into 10-foot lengths or smaller.

5. All pipes and ducts shall be cut to sizes no greater than 20 feet in length. Concrete pipes shall be crushed radially. other pipes and ducts 6 inches and larger in diameter shall be longitudinally cut in half.

6. Underground tanks, vats, and the like shall be emptied of contents prior to removal and demolition. The contents will be identified by the contractor for making a determination of safe handling and disposal procedures. See Section 02081, Article 3.1.B for removal and disposal of the wastes.

7. After the completion of the construction phase, the synthetic membrane liner(s) shall be removed, decontaminated and disposed of as the subcontractor's property. If the membrane liner(s) cannot be decontaminated by practical means, it shall be disposed of by cutting into strips, no wider than four feet, and placed in the tailings embankment in a manner that wolidd not induce settlement or inhibit water migration.

8. The sprinkler system shall be removed concurrently with the excavation of the tailings.

9. Used rubber tires shall be collected, cut up radially into two halves and placed in the tailings embankment as specified in section 02200 or decontaminated as directed by the contractor and disposed of offsite as subcontractor's property.

\subsection{DISPOSAL OF DEMOLISHED MATERIALS AND DEBRIS}

A. Unless otherwise directed by the site Manager, demolished materials and debris shall be disposed of in the tailings embankment as specified in section 02200 and as shown on the Subcontract Drawings.

B. Burning of materials will not be permitted.

\section{PART 4 - MEASUREMENT AND PAYMENT}

\subsection{MEASUREMENT}

A. Measurement for payment for the demolition and disposal of structures specified in this section will be on a lump sum basis. The measurement will not include the following: 
1. Demolition and disposal of decontamination pads and sumps.

2. Membrane liner(s) installed under section 02771.

[3. Fencing installed under sections 02833 and 02835.]*

\subsection{PAYMENT}

A. Payment for demolition and disposal of structures specified in this section will be by the lump sum price quoted therefor in the Bid Schedule. The price quoted shall include full compensation for furnishing all labor, materials, tools, equipment, incidentals, and for performing all work including all clearing, demolishing, breaking of the debris into small pieces, removal, demolition, and decontamination of facilities where required, and disposing of demolished materials and debris as specified in this Section.

B. Payment for demolition and disposal of decontamination pads and sumps will be considered to be included in the applicable lump sum prices quoted in Section 01500 .

c. Payment for demolition and disposal of membrane liner(s) installed under section 02771 will be as specified in section 01500 .

END OF SECTION 02050

* P.I.D. 06-S-17

Document No. 3885-RFL-S-01-00736-04

Issued for Construction-Revision 1 


\section{SECTION 02081}

ASBESTOS, HAZARDOUS AND NON-HAZARDOUS MATERIALS

\section{PART 1 - GENERAL}

\subsection{SCOPE}

A. This specification section describes the requirements for handling, transportation of, and disposal of existing stockpiles and containers of: (1) friable and non-friable asbestos-containing material, (2) toxic chemicals, hazardous materials, and other chemicals, and (3) other non-hazardous materials from the processing sites.

B. The subcontractor shall furnish all labor, materials, services, supervision, insurance, and equipment necessary to carry out the handling and disposal work in accordance with regulations of the Environmental Protection Agency (EPA) and the occupational Safety and Health Administration (OSHA) and any applicable state and local government regulations.

C. The requirements specified in this section are supplemental to the requirements specified in General Provisions, General Conditions and special conditions.

1.2 RELATED WORK

A. Section 00800 - Special Conditions: Articles SC-7, SC-8 and SC-13.

B. Section 02200 - Earthwork: Handling and Disposal of Asbestos and Non-Hazardous Materials.

\subsection{DEFINITIONS}

See section 00800, Article SC-1.

\subsection{CODES AND REGULATIONS}

A. The Subcontractor shall comply with the applicable codes and regulations including, but not limited to, the following:

1. U.S. Department of Labor, Occupational Safety and Health Administration ("OSHA"):

Document No. 3885-RFL-S-01-00737-04

Issued for Construction-Revision 1

Asbestos, Hazardous and Non-Hazardous Materials 8082S/WP51 
a. 29 CFR 1910.120, "Hazardous Waste Operations and Emergency Response".

b. 29 CFR 1926.58, which includes regulations governing supervision by a "competent person" and air sampling by approved National Institute of Occupational safety and Health (NIOSH) methods.

2. Environmental Protection Agency ("EPA"):

National Emissions Standard for Hazardous Air Pollutants (NESHAPS) 40 CFR 61, Subparts $A$ and $M$

3. [State of Colorado Department of Health ("CDH"):]*

a. Section 8 of the Regulations Pertaining to solid Waste Disposal sites and Facilities.

b. Other provisions of the Solid Waste Regulations for non-asbestos non-hazardous waste.

c. C.R.S. 25-15-101 for offsite disposal of hazardous waste to an approved hazardous waste site.

B. Posting Regulations: Copies of applicable OSHA, EPA and [Colorado $\mathrm{CDH}$ regulations]* shall be obtained by the Subcontractor and one copy of each shall be posted on the job site for the information of his employees. The EPA notification of asbestos removal, including the "plan of procedures to be employed for compliance with EPA regulations", shall also be posted at the job site.

\subsection{NOTIFICATION AND APPROVAL REQUIREMENTS}

A. Ten days prior to the handling and disposal of asbestoscontaining materials, the subcontractor shall submit a written notice to the Colorado Department of Health, Air Pollution Control Division. A copy of the notice shall also be submitted to the Contractor. Notice shall be in compliance with applicable statutes and regulations.

B. Upon completion of asbestos handling and disposal work, the subcontractor shall submit a written report to the colorado Department of Health, Air Pollution Control Division with a copy to the contractor. The report shall comply with Colorado Department of Health requirements.

* P.I.D. 06-S-17

Document No. 3885-RFL-S-01-00737-04

Issued for Construction-Revision 1 
A. The airborne asbestos exposure outside of asbestos controlled areas shall not exceed 0.1 fibers/cc air, 8-hour timeweighted average (TWA), which is the action level before reaching 0.2 fibers/cC air, 8-hour TWA, the permissible exposure limit.

B. All air monitoring for asbestos and other hazardous materials shall be performed under the supervision of a "competent person" as defined in 29 CFR 1926.58 (b), (e) and Appendix F. Air monitoring in areas where hazardous materials are stored or handled shall comply with 29 CFR 1910.120.

c. Documentation of each air sample shall be as specified by the site Manager and shall include at least the date and time, sample number, exact sampling location, name of individual performing sampling, sampling rate, sampling volume, analytical method, analytical results and limits of quantification and detection as per NIOSH analytical methods.

D. Analysis of air samples for asbestos shall be by NIOSH 7400 method. All asbestos and chemical samples shall be analyzed by a qualified Contractor-approved laboratory. Results shall be reported to the site Manager and Albuquerque Project office Safety and Health Department within five working days.

E. Preliminary air sampling shall be sufficient to establish the perimeters of asbestos and other hazardous materials control areas to the satisfaction of the site Manager. During asbestos handling work, air samples shall be taken continuously outside each asbestos control area, within ten feet of each decontamination enclosure system exit and within ten feet of each HEPA exhaust [if applicable]*.

F. Air samples shall be taken in the breathing zones of workers removing asbestos and other hazardous materials in sufficient numbers to permit estimation of peak and Time Weighted Average (TWA) exposures. At a minimum, for TWA exposures, one personal sample from the worker with the highest probable exposure is required in each asbestos control area per work shift.

G. The subcontractor shall submit to the contractor a copy of all air monitoring results within seven days of the subcontractor's receipt of results.

* P.I.D. 06-S-17

Document No. 3885-RFL-S-01-00737-04

Issued for Construction-Revision 1 


\subsection{SUBMITTALS}

A. The subcontractor shall, within fifteen days after receipt of Notice to Proceed, prepare and submit the following, as specified in this section:

1. Asbestos Handling, Transportation and Disposal Plan.

2. Hazardous Materials Handling. Transportation and Disposal plan.

3. Subcontractor Qualifications.

4. Qualifications of Health and Safety Personnel.

5. Training Certificates of all Asbestos Abatement Workers in compliance with the provisions of 40 CFR 763 (App. C).

6. Training certificates for all hazardous materials workers in compliance with the provisions of 29 CFR 1910.120.

7. Training certificate of one supervisor certified by U.S. EPA, National Asbestos Training Center, or Satellite Center, or equivalent.

[8. Proof of liability insurance and Workmens Compensation Coverage.

9. Proof of state of Colorado Abestos Abatement contractor licensure.

10. Emergency Asbestos Abatement Contingency Plan for spills, leaks, or any release occurring during handling, transportation or disposal.

11. Emergency Hazardous Materials contingency Plan for spills, leaks, or any release occurring during handling, transportation or disposal.]*

B. Asbestos and Hazardous Materials Handling Plan:

1. In addition to the submittals specified in section 01300 , the subcontractor shall submit a detailed plan of the work procedures to be used in the handling of asbestoscontaining materials and other hazardous materials. Such plan shall include:

$\star$ P.I.D. 06-S-17

Document No. 3885-RFL-S-01-00737-04

Issued for Construction-Revision 1

Asbestos, Hazardous and Non-Hazardous Materials 8082S/WP51 
a. Construction details of the control barrier.

b. Air monitoring plan.

c. Equipment decontamination plan.

d. Location of control areas.

e. Layout of change rooms.

f. Disposal plan.

g. Type of wetting agent and asbestos sealer to be used.

h. Personal protective equipment.

[i. Emission/Release prevention plan which ensures zero release conditions and proper work practices.]*

2. This plan shall be approved by the contractor prior to the start of any asbestos or hazardous material work.

3. The subcontractor and his assigned asbestos abatement and hazardous materials remediation specialist shall meet with the contractor prior to beginning work to discuss the plan in detail, including work procedures and safety precautions.

c. Subcontractor Qualifications:

1. A statement demonstrating subcontractor's understanding of asbestos abatement and hazardous materials remediation shall include the following as a minimum:

a. Knowledge of asbestos abatement techniques and state-of-the-art practices and equipment.

b. Knowledge of OSHA, EPA, NIOSH, DOH, [DOE,]* and any other applicable regulations and requirements regarding asbestos abatement and hazardous materials remediation work practices and equipment.

c. Knowledge of the special safety hazards and requirements associated with asbestos abatement and hazardous materials remediation work.

d. Knowledge of the health hazards of asbestos and site specific hazardous materials.

[ Text Deleted] *

* P.I.D. 06-S-17

Document No. 3885-RFL-S-01-00737-04

Issued for Construction-Revision 1

Asbestos, Hazardous and Non-Hazardous Materials 8082S/WP51 
D. Qualifications of Person Responsible for Health and Safety:

1. A statement demonstrating the qualifications and experience of the person responsible for Health and safety and air monitoring technicians that the subcontractor intends to employ on this project shall include the following as a minimum:

a. A record of experience qualifying the Health and safety person as a professional specializing in asbestos abatement and hazardous materials remediation. As a minimum, this shall include a review of previous experience in asbestos abatement and hazardous materials remediation projects, including the names, addresses and telephone numbers of the purchasers of the services; locations of the work performed; and a review of the industrial hygiene activities performed for each job.

b. A description of each air monitoring technician's training in asbestos and hazardous materials air monitoring, and a review of previous air monitoring experience in asbestos and hazardous materials removal projects, including the names, addresses and telephone numbers of the purchasers of the services; locations of the work performed; and a review of all air monitoring and other inspection activities performed for each job.

c. A statement for each person who may be doing asbestos air sample analysis, indicating the qualifications, training program and experience in asbestos air sample analysis, analytical methods used, dates of training, and average number of asbestos samples analyzed per month in the last twelve months.

d. A statement indicating the Health and Safety person's degree of authority on this project for effecting corrective actions deemed necessary in his or her judgement.

1.8 COLORADO DEPARTMENT OF HEALTH, AIR QUALITY CONTROL DIVISION REQUIREMENTS

A. The subcontractor shall comply with the following provisions of Colorado Air Quality Control Commission Regulation No. 8 of the state Solid Waste Regulations:

Document No. 3885-RFL-S-01-00737-04

Issued for Construction-Revision 1

Asbestos, Hazardous and Non-Hazardous Materials 8082s/WP5I 
1. As of July 1, 1987, all persons who wish to conduct asbestos abatement work in colorado are deemed certified according to the requirements contained in C.R.S. 25-7-505 providing that 1) all the applicant's employees have been trained according to Federal occupational Safety and Health Administration worker training requirements for asbestos abatement workers, and 2) the applicant employs at least one trained supervisor who must be on-site at all times when abatement work is proceeding.

2. As of July 1, 1987 , all abatement project supervisors shall be deemed certified as trained supervisors according to the requirements contained in C.R.S. 25-7-506 providing an applicant has completed a three-day or longer asbestos abatment supervisory course given by any U.S. Environmental Protection Agency National Asbestos Training Center or satellite Center, or equivalent, within the preceding 12 months from enactment of this regulation.

\section{PART 2 - PRODUCTS}

\subsection{EQUIPMENT}

A. The subcontractor shall include in the handing, transportation and disposal plans, specified in Article 1.7 above, the construction aids he intends to provide.

B. Construction aids shall be cleaned and free of radiologically contaminated asbestos fibers and other radiologically contaminated hazardous materials (and radioactive contamination as specified in Article sc-8 of the special Conditions) before removal from site-controlled work areas.

c. The subcontractor shall provide all necessary transport vehicles for hauling the radiologically contaminated asbestos-containing and other radiologically contaminated hazardous materials to the disposal area and shall provide excavating and compacting equipment for encapsulation of the radiologically contaminated asbestos-containing and other hazardous materials in the disposal area.

D. The subcontractor shall provide all necessary transport vehicles for hauling the radiologically contaminated asbestos-containing and other hazardous materials that [CDH]* will allow for deposit at the disposal site. The subcontractor shall abide by U.S. Department of 
Transportation requirements (49 CFR 170-173) for this haul. The conditions under which these transport vehicles will be supplied, used, and returned to regular service is contained in an agreement between Nielsons, Inc. and MK-Ferguson dated 18 November 1989.]

\section{PART 3 - EXECUTION}

\subsection{GENERAL}

A. Handling, transportation and disposal of asbestos-containing materials and other hazardous and non-hazardous materials shall conform to the applicable requirements of colorado Department of Health's Regulations Pertaining to Solid Waste Disposal sites and Facilites.

B. Transport and disposal of asbestos-containing materials shall conform to $40 \mathrm{CFR} 61.152$ and $40 \mathrm{CFR} 61.153$.

c. The radiologically contaminated asbestos scrap shall be transported to the disposal site and disposed of in a designated area as directed by the contractor and as specified in Paragraph 3.1. A of this section. The use of such designated area(s) shall appear as part of the Certificate of Designation for the tailings encapsulation cell. [Bags shall be placed in one layer with not less than two feet space between bags and covered immediately with at least two feet of soils compacted as specified in Paragraph $3.2 \cdot C .2]$.

D. Other Radiologically-Contaminated Hazardous and Radiologically-Contaminated Non-Hazardous Waste Materials: The other radiologically contaminated hazardous and radiologically contaminated non-hazardous waste materials shall be transported to and disposed of in the tailings embankment as shown on the subcontract Drawings.

E. Transport and disposal of other hazardous and non-hazardous waste material shall conform with the Colorado Hazardous Waste Regulations 6 CCR 1007-3.

* P.I.D. 06-S-17

Document No. 3885-RFL-S-01-00737-04

Issued for Construction-Revision 1

Asbestos, Hazardous and Non-Hazardous Materials 8082S/WP5I 


\subsection{ASBESTOS-CONTAINING MATERIALS}

A. Asbestos materials handling and disposal shall conform to the requirements of this section and to section 8 of the Colorado Department of Health's Regulations Pertaining to Solid Waste Disposal sites and Facilities. In case of any conflict, the Contractor will determine the applicability of a particular code or standard.

B. Types of Asbestos-Containing Materials:

1. General: The materials specified in Paragraph 2 below are either contained in stockpiles or in containers at the processing sites. The available description/ characterization of these materials is shown in the Information to Bidders.

2. Asbestos-Containing Material:

a. Friable Asbestos Thermal Insulation

b. Asbestos Insulated Wire

c. ACM Floor Tile

d. ACM Coated Building Panels

e. Transite Panels

f. Transite Pipe

g. Flanges with Gaskets

h. Asbestos Brick

[i. Asbestos soil mixtures as contained inside the storage area.]*

C. Disposal Location, Transport and Burial:

1. All friable and non-friable asbestos is stored at an area shown on the subcontract Drawings. The area is distinguished by flags or by boundary markers. The flags or markers are installed at each corner of the area and at a spacing not exceeding 40 feet.

2. Asbestos-containing materials shall be adequately contained for transport to the storage site. The methods of containment shall include sealing, wrapping, bagging,

*P.I.D. 06-S-17

Document No. 3885-RFL-S-01-00737-04

Issued for Construction-Revision 1

Asbestos, hazarâous and Noñ-riazardous Materials 80825/wr5i 
enclosure in drums, or other contractor-approved method. [Each package of ACM shall be labeled with the proper OSHA-DOT labels and generators name and address. Each transport vehicle shall be marked with the appropriate DOT and EPA information pursuant to current applicable regulations. Each shipment of $A C M$ shall be accompanied by a waste shipment record provided, and completed by the subcontractor.]* All ACM shall be buried within 24 hours of arrival at the disposal cell to prevent suspension in air of asbestos fibers. The ACM shall be placed in windrows and covered with two feet of fill and the surface shall be rolled by machinery to remove voids. [Text Deleted]* [Compaction shall be accomplished by any of the following combinations of passes and equipment, or approved equal combination:

a. Three passes of a Caterpillar Compactor Model 825C or equivalent.

b. Four passes of a track-type tractor with ground pressure of $9.8 \mathrm{psi}$ or greater.

c. Five passes of a fully-loaded Caterpillar wheel Tractor Scraper Model $631 \mathrm{E}$ or equivalent.]*

3. Transport and disposal shall conform to 40 CFR 61.152, 40 CFR 61.153, and 40 CFR 1090. All asbestos-containing materials are radiologically contaminated and shall be disposed of in the cell. The transport vehicle shall enclose the asbestos while on route to the disposal cell. The transport vehicle shall be lined in plastic so spilled asbestos rosidues are easily cleaned by a properly trained person. The asbestos shall be buried under at least 2 feet of soils compacted in a manner to prevent resuspension within 24 hours of arrival at the disposal cell.

4. The materials and containers shall be transported to the disposal site and disposed of in an area or areas of the disposal cell designated by the contractor. The use of such designated area(s) shall appear as part of the Certificate of Designation for the tailings encapsulation cell. Preparation of the as-built drawings showing the final disposal location and elevation is the responsibility of the subcontractor in accordance with the requirements of Article 3.2.E.9.b.

* P.I.D. 06-S-17

Document No. 3885-RFL-S-01-00737-04

Issued for construction-Revision 1

Asbestos, Hazardous and Non-Hazardous Materials 8082S/WP51 RFL-PH-II $02081-10$ 
D. Cleaning Work Areas After Asbestos Removal:

1. After asbestos-containing materials have been transported, work areas and transport vehicles shall be cleaned with significant assurance that no asbestos fibers shall become airborne when other work takes place.

2. The subcontractor shall notify the contractor's site Manager when work is complete for a final visual inspection.

3. Clearance Air Sampling: Aggressive air sampling (as per EPA) shall be conducted to the satisfaction of the site Manager at each asbestos controlled work area. Asbestos contamination levels must be below 0.01 fibers/cc air.

E. Colorado Approved Asbestos Disposal Plan:

1. General:

a. During the Uranium Mill Tailings Remedial Action (UMTRA) demolition process, sources of friable and non-friable Asbestos Containing Materials (ACM) have been removed, packaged, and stored on-site. These sources of $A C M$ are radiologically contaminated and are designated for disposal within the mill tailings disposal cell.

b. The methods for handling, transporting, and burial of the $A C M$ are addressed in this disposal plan. Applicable regulations including OSHA 29 CFR 1926.58, EPA 40 CFR Part 61, and State of Colorado Air Quality Control Regulation Number 8 have been referenced during development of this work plan.

2. Personnel: Only personnel who are adequately trained and knowledgeable in the hazards of asbestos, proper work procedures, use of respiratory protection, and use of personal protective equipment are allowed to handle the ACM during the disposal process. Personnel who perform this work shall meet the applicable regulations of OSHA 29 CFR 1926.58.

3. Packaging ACM: Friable ACM has been double bagged in $6 \mathrm{mil}$ polyethylene asbestos disposal bags which have warning labels applied. The warning labels state "DANGER, CONTAINS ASBESTOS FIBERS, AVOID CREATING DUST, CANCER AND LUNG DISEASE HAZARD". The friable ACM shall remain packaged in this manner throughout the disposal process.

Document No. 3885-RFL-S-01-00737-04

Issued for Construction-Revision 1

Asbestos, Hazardous and Non-Hazardous Materials 80825/WP51 
4. Asbestos Emissions: No visible emissions of dusts will be permitted during the handing, transportation, or disposal process of the ACM. Adequate dust control measures, such as wet methods shall be used, as necessary, to prevent any of the friable or non-friable ACM from releasing fibers. Water sprays will be required to control fibers during the burial of $A C M$ in case of accidental bag rupture or transite pipe breakage. In the case where the ACM bags need to be punctured to release trapped air so that proper compaction after burial may occur, extra water shall be continually applied at the point of puncture. Water used for dust control shall be applied by using hand held garden sprayers, water spray compressors, or water trucks with hoses.

5. Handling $A C M$ :

a. All personnel that handle $A C M$ during the disposal process shall wear, at a minimum, a half mask respirator with High Efficiency Particulate Air (HEPA) filters, Tyvek coveralls with hoods (or equivalent), proper protective gloves and work boots. Additional respiratory protection may be required in order to comply with OSHA 29 CFR 1926.58 requirements.

b. All personal protective equipment used during the disposal process including respirator cartridges shall be bagged and disposed of as required in this plan.

6. Work Zones: Work zones shall be constructed around all areas where ACM is handled during the disposal process. The work zone shall include a "contaminated" area and a "clean" area constructed of hazard barrier tape. Only personnel adequately trained and protected may enter the "contaminated" work zone area.

7. Air Monitoring:

a. Air monitoring for asbestos shall be performed on personnel who have the highest potential exposures and around the perimeters of the work zones to determine area concentrations.

b. Results from this monitoring will be made available to the subcontractor for personnel involved in the disposal process.

c. Air monitoring and analytical techniques shall comply with OSHA 29 CFR 1926.58 requirements.

Document No. 3885-RFL-S-01-00737-04

Issued for Construction-Revision 1

Asbestos, Hazardous and Non-Hazardous Materials 8082S/WP51

$$
02081-12
$$


8. Transportation of ACM:

a. All ACM shall be loaded into a covered vehicle which has been properly lined with polyethylene plastic. The covered vehicle shall be constructed to ensure that no fibers are released during transportation to the cell. The inside lining shall be designed to facilitate the decontamination process when the ACM is off-loaded.

b. A complete inspection of the trucks and trailers used to transport the $A C M$ will be performed in accordance with the UMTRA Site Truck Inspection Plan before the ACM is transported to the disposal cell.

9. Burial:

a. When the ACM is transported to the tailings disposal cell, burial shall occur with 24 hours after the ACM is removed from the vehicle. This requirement is necessary to ensure that the $A C M$ remains in a controlled condition at all times.

b. The contractor will select an appropriate area in the cell where burial shall occur and the subcontractor will be directed as to how the ACM shall be spaced and deposited into trenches and pits during the burial process so that voids are eliminated. The location of the trenches and pits shall be clearly documented by the subcontractor. [ACM shall not be placed within 100 feet of the perimeter of the tailings embankment.]*

c. The $A C M$ shall be covered with a minimum of 24 inches of compacted tailings to ensure stable placement.

10. Future Excavated Transite Pipe: Transite pipe that is discovered during remedial action activities shall be handled by employees trained in the hazards of asbestos per OSHA 29 CFR 1926.58. The transite pipe shall be immediately wetted with water and kept wet until buried in the tailings disposal cell. Employees who handle excavated transite pipe will be monitored for exposure to airborne asbestos fibers by the contractor's Industrial Hygienist as required.

* P.I.D. $06-S-17$

Document No. 3885-RFL-S-01-00737-04

Issued for Construction-Revision 1

Asbestos, Hazardous and Non-Hazardous Materials 8082S/WP51 
F. Asbestos and Hazardous Materials Storage Area: The storage area shall be maintained until all materials have been removed. The storage area shall then be demolished. Maintenance includes keeping functional all berms, fencing, gates, signs, trailers, drums, the gravel base and the drainage system functional and in good repair.

\subsection{OTHER HAZARDOUS AND NON-HAZARDOUS MATERIALS}

A. General:

1. Hazardous materials sampling, handling, storage and associated record keeping shall conform to colorado Department of Health Hazardous Wastes Regulations 6 CCR 1007-3.

B. Handing, transport and disposal of non-hazardous materials shall conform to applicable state and local regulations pertaining to solid waste disposal.

C. Work areas where hazardous materials or hazardous wastes have been remediated shall be cleaned with significant assurance that no residual contamination remains.

D. Hazardous Materials in Drums:
a. Radiologically Contaminated Selenium
b. Molybdenum Contaminated Solids
c. Contaminated Grease
d. Scrap Material

E. Selenium Tailings Residue Disposal: The approximately 33 drums of selenium tailings residue were removed from the uranium mill selenium circuit. They are chemically and radiologically similar to mill tailings. This material shall be handled, transported, and disposed of in the same manner as mill tailings. The polyethylene drums that contain the 55-gallon capacity metal drums of selenium tailings residue are the property of the contractor and the Subcontractor shall either radiologically decontaminate the drums or shred and dispose of the drums in the disposal cell, as directed by the contractor.

F. Disposal of Drained Acid Lines: The acid lines shall be handled by properly trained personnel meeting the training requirements of 29 CFR 1910.120. The lines shall be transported to the disposal cell in the same manner as other scrap metal. The acid lines shall be immediately buried in

Document No. $3885=R F L=S=01-00737-04$

Issued for Construction-Revision 1

Asbestos, Hazardous and Non-Hazardous Materials 8082S/WP51 $02081-14$ 
a manner consistent with the methods used for scrap metal and in a location selected by the contractor.

G. The Subcontractor shall notify the Contractor's Site Manager when work of this section has been completed for final inspection.

\section{PART 4 - MEASUREMENT AND PAYMENT}

\subsection{MEASUREMENT}

Measurement for payment for handling and disposal of existing stockpiles of asbestos, hazardous and other non-hazardous waste materials will be as specified in section 02200 .

\subsection{PAYMENT}

Payment for handling and disposal of existing stockpiles of asbestos, hazardous and other non-hazardous waste materials will be as specified in section 02200. The price quoted shall include full compensation for furnishing all labor, materials, equipment, tools, accessories and incidentals and for performing all work as specified including, but not limited to, all fees and permits and compliance with the codes and standards.

END OF SECTION 02081

Document No. 3885-RFL-S-01-00737-04

Issued for Construction-Revision 1 


\section{SECTION 02090}

\section{SEALING MONITOR WELLS}

\section{PART 1 - GENERAL}

\subsection{SCOPE}

A. This specification section describes the requirements for sealing of existing monitor wells.

B. Table 02090-1 lists all known wells that are to be sealed.

\subsection{APPLICABLE PUBLICATIONS}

A. The Publications listed below form a part of this specification to the extent referenced. The publications are referred to in the text by the basic designation only:

1. Manual of Water Well Construction Practices, Environmental Protection Agency, EPA-570/9-75-001.

2. American Society for Testing and Materials (ASTM): C150-86 standard Specification for Portland Cement (Rev. A).

3. State of Colorado, Revised and Amended Rules and Regulations for water Nell Construction and Pump Installation, August 1, 1988, 2CCR 402-2.

\subsection{SITE CONDITIONS}

In addition to the wells listed on Table 02090-1, there are other wells in the vicinity of the three sites. Wells not designated to be sealed or demolished shall be protected to prevent damage during construction. Such wells, if damaged, shall be reconstructed by the subcontractor at no cost to the contractor. 
TABLE 02090-1

WELLS TO BE SEALED

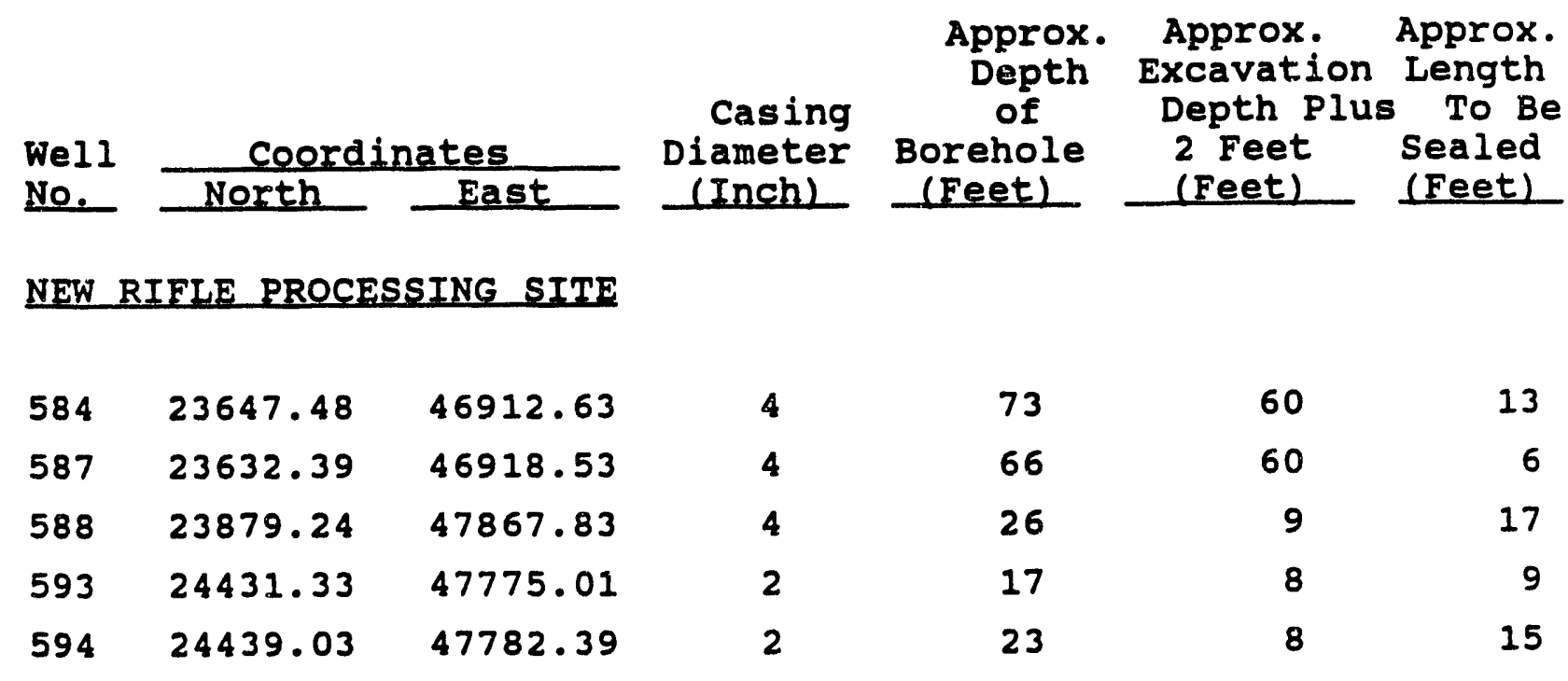

OLD RIFLE PROCESSING SITE

$584 \quad 25856.51 \quad 61016.41$

4

17

6

11

ESTES GULCH DISPOSAL SITE

$\begin{array}{lrrrrrr}958 & 56985.603 & 53124.522 & 4 & 116 & 2 & 114 \\ {[962} & 57492.628 & 51979.989 & 4 & 72 & 5 & 67 \\ 963 & 57469.430 & 52779.524 & 4 & 301 & 32 & 269 \\ 964 & 57512.033 & 52812.143 & 4 & 218 & 31 & 187] *\end{array}$

* Revision 
PART 2 - PRODUCTS

\subsection{MATERIALS}

A. Approved sealing materials are as follows:

1. [Cement used for sealing mixtures shall meet the requirements of ASTM C150 "standard Specification for Portland cement," Type II Low E (moderate sulfate resistance) or Type $V$ (high sulfate resistance) or approved equal.]*

2. Cement grout shall be composed of one sack of Portland Cement ( 94 pounds), with 3 to 5 percent, by weight, of commercially processed sodium bentonite, to not more than 6 gallons of potable water in order to achieve a weight of not less than 15 pounds per galion. The weight of the neat cement shall be sufficient to prevent flow of water into the well from any aquifer penetrated. Calcium chloride may be added to a portland cement grout to accelerate the set, but it shall not exceed 2 pounds per sack of dry cement.

\section{PART 3 - EXECUTION}

\subsection{GENERAL}

A. The state of colorado well abandonment regulations specified in Article 1.2.A.3 require that wells be sealed in a manner that is compatible with the well design and so as not to act as a conduit for future contamination of groundwater. Detailed well sealing criteria are outlined in the Environmental protection Agency (EPA) Manual of Water Well Construction Practices, EPA-570/9-75-001, Article 56, pages 133-142. The basic premise of the EPA criterion is to seal abandoned wells and to restore, as much as possible, the geohydrologic regime in existence before the well was constructed. The following criteria shall apply to all wells to be sealed on and in the vicinity of the processing and disposal sites:

1. The subcontractor shall notify the contractor 10 days prior to commencement of well sealing operations.

2. Well sealing operations shall be performed by a statelicensed (Colorado) drilling contractor.

* Revision 
3. All wells shall be sealed in such a manner that they will not act as a conduit for fluids to flow from the specific strata in which they were originally encountered.

4. All wells shall be located in the field and sealed by the subcontractor prior to the beginning of stripping, grading or other surface-disturbing activities that will hinder the detection and sealing of wells. If any well cannot be located after a reasonable search, the Subcontractor shall, prior to the commencement of the well sealing operations, submit to the contractor a written report documenting the well number, the areas covered and the effort spent in the search.

5. Upon discovery of any unknown wells during the earthwork operations, the subcontractor shall give the site Manager immediate verbal notice followed by written confirmation within 24 hours. Further earthwork activities in the immediate vicinity of the well shall be suspended until approved by the contractor.

6. Wells shall be sealed according to the following procedures:

a. The Subcontractor shall check each well to be sealed for obstructions that may interfere with the sealing operation and shall remove any such obstructions and notify the contractor prior to starting filling operations.

b. In order to seal the well properly it is preferrable to remove the well casings by methods approved by the contractor as outlined in Article 56 of the EPA Manual of Water Well Construction Practices. Upon removal, if the casings and the materials are found to be contaminated, they shall be decontaminated as required by the contractor, or stockpiled with demolition debris after breaking into lengths not greater than 10 feet. If casing removal is not feasible, the casing shall be perforated, ripped or otherwise disintegrated by methods outlined in Article 56, to ensure grouting of the entire annular space between the casing and the borehole.

c. The approved methods for the placement of a grout seal shall be as follows:

Document No. 3885-RFL-S-0̃I-0̄0738-03

Issued for Construction-Revision 0

sealing Monitor Wells 
1) In wells where casing is removed, the cement grout shall be introduced at the bottom of the well or interval to be sealed (or filled) and placed progressively upward to the top of the well. The grout shall be placed by the use of grout pipe, drop pipe, tremie, cement bucket or dump baller, in such a way as to avoid segregation or dilution of the sealing materials. Dumping grout material from the top of the well shall not be permitted.

2) In wells where casing is not removed, the calculated amount of neat cement grout required to $f i l l$ the well interval plus the annular space outside the lining shall be placed within the space to be cemented. The cement shall be introduced into the well through a tremie pipe extending to the bottom of the well. The cement shall be introduced to fill both the inside of the pipe and any voids around the outside of the pipe. The well shall be cemented all the way up to ground surface.

d. For all wells located in areas where the construction grade elevation will be greater than or equal to the existing grade surface, existing casings and cement grout seals shall be removed to a minimum depth of 2 feet below the existing grade surface, and as otherwise required for construction. Grouting shall extend to 2 feet below the existing grade. The interval from the top of the grout to the existing grade surface shall be filled with a mixture of uncontaminated soil (ML or $C L$ ) and a minimum of 25 percent by weight of commercially processed sodium bentonite. The mixture of uncontaminated soil shall be hand-tamped, as required.

e. For all wells located in areas where the construction grade surface will be less than the existing grade surface (i.e. in areas of proposed cut), the existing casings and cement grout seals shall be removed to a minimum of 2 feet below the grade cut elevation and as otherwise required for construction. Grouting shall extend to 2 feet below the grade cut elevation. The interval from the top of the grout to construction grade surface shall be filled with a mixture of uncontaminated soil (ML or CL) and a minimum of 25 percent by weight of 
commercially processed sodium bentonite. The interval from the top of the soil/bentonite mixture shall be filled with available soil. The uncontaminated soil mixture and available soil shall be hand-tamped, as required.

7. Within 30 days of the completion of well sealings, the Subcontractor shall submit a Well Abandonment Affidavit to the Colorado Division of Water Resources. A copy of the affidavit shall be submitted to the contractor.

\section{PART 4 - MEASUREMENT AND PAYMENT}

\subsection{MEASUREMENT}

Measurement for payment for sealing of monitor wells will be by the linear feet of wells sealed, as measured from the bottom of well to the top of the soil-bentonite mixture.

\subsection{PAYMENT}

Payment for sealing of monitor wells will be by the unit price per linear foot quoted therefor in the Bid schedule. The price quoted shall include full compensation for furnishing all materials, equipment, tools, accessories, incidentals, labor, and for performing the work specified in this section including decontamination and disposal of materials and equipment.

END OF SECTION 02090

Document No. 3885-RFL-S-01-00738-03 
SECTION 02110

SITE CLEARING

\section{PART 1 - GENERAL}

1.1 SCOPE

This Specification section describes the requirements for clearing and grubbing of vegetation, stripping of topsoil, tree removal, and disposal of cleared and stripped materials.

\subsection{DEFINITIONS}

A. Clearing: Clearing is defined as removing all materials from the areas where the general ground cover is higher than two feet. Clearing shall consist of removal of immature trees not included in Tree Removal below, logs, upturned stumps, roots of downed trees, brush, grass, weeds, and all other like materials, within the limits of construction. All such materials shall be cleared down to the natural ground surface.

B. Grubbing: Grubbing is defined as remova. of all stumps, trees and roots up to eight inches in diameter, buried logs, and all other like material up to the depth of three feet below the existing ground surface or subgrade whichever is deeper. Grubbing shall be performed within the limits of clearing and shall extend to the outside excavation and fill slope lines.

c. Topsoil: Topsoil for use as seed bed shall be free of any admixture of subsoil, foreign matter, toxic substances, and any material or substance that may be harmful to plant growth.

D. Stripping of Topsoil: This shall consist of the removal of topsoil, including all roots and organic materials and vegetation less than two feet high, and any other unsuitable material. Depth of stripping shall be 6 inches.

E. Tree Removal: Tree removal is defined as felling and disposing of trees having a diameter of eight inches or greater when measured six feet above the ground. Trees shall be felled and the stumps and roots removed to a depth of three feet below the natural ground surface.

Document No. 3885-RFL-S-01-00739-04

Issued for Construction-Revision 1 
1.3 RELATED WORK
A. Section 02200 - Earthwork
B. Section 02935 - Seeding

PART 2 - PRODUCTS

(Not Used)

PART 3 - EXECUTION

\subsection{PRESERVATION OF PROPERTY}

Existing improvements, adjacent property, utility and other facilities, and trees and plants that are not to be removed shall be protected from injury or damage.

\subsection{CLEARING AND GRUBBING}

A. Trees and limbs less than 8 inches in diameter and all other vegetation, including grasses, weeds and shrubs in areas of construction activities shall be burned where permitted or otherwise disposed of as subcontractor's property.

B. The subcontractor shall dispose of cleared materials. Combustible uncontaminated cleared waste may be disposed of by burning. The subcontractor shall be responsible for obtaining required permits for burning such wastes from Colorado Department of Health, Air Pollution control Division.

[C. The subcontractor shall clear and grub all areas to be used for stockpiling of fill materials.]*

\subsection{STRIPPING}

A. Uncontaminated Areas: Stripping will be required in the following areas:

1. Beneath all fills in areas where excavation is not otherwise required;

* P.I.D. 06-S-17 
2. Beneath areas of riprap protection where excavation is not otherwise required.

3. In areas of excavation where excavated materials are to be used as fill.

B. Contaminated Areas: In areas of excavation where the contaminated surfaces are covered by vegetation, the removal of topsoil may be carried out together with the excavation in one operation.

c. Stripped material shall be disposed of as specified in Article 3.5 .

\subsection{TREE REMOVAL}

A. Tree removal shall be subject to Contractor approval.

B. The waste resulting from tree removal shall be burned where permitted or otherwise disposed of as subcontractor's property.

3.5 STOCKPIIING OF UNCONTAMINATED TOPSOIL

stockpiling of uncontaminated topsoil shall be performed only when required by the Contractor upon his determination that there is sufficient uncontaminated organic topsoil in the area to justify the operation; otherwise the materials shall be disposed of in an approved spoil area shown on the Subcontract Drawings, or as subcontractor's property. The topsoil from the stockpile shall be used in finish grading of the site.

3.6 BURNING OF CLEARED AND STRIPPED MATERIAL

Burning of cleared and stripped materials in contaminated areas will not be permitted.

PART 4 - MEASUREMENT AND PAYMENT

\subsection{MEASUREMENT}

A. With the exception of the following item, separate measurement for payment will not be made for work specified in this Section:

Document No. 3885-RFL-S-01-00739-04

Issued for Construction-Revision 1

$$
\text { site clearing }
$$


1. Clearing, Grubbing and Tree Removal at Estes Gulch Disposal Site

B. Measurement for payment for clearing, grubbing and tree removal at the Estes Gulch Disposal site will be by the acres of area cleared and grubbed. The quantities for payment will be calculated from the projection of the area on the horizontal plane.

\subsection{PAYMENT}

A. Clearing, Grubbing and Tree Removal at the Estes Gulch Disposal site: Payment for clearing, grubbing and tree removal at the disposal site will be by the unit price per acre quoted therefor in the Bid schedule. The price quoted shall include full compensation for disposal of the cleared material including felling, trimming, and disposal of trees. The price quoted shall include full compensation for furnishing all labor, materials, tools, equipment, and incidentals, and for doing all the work involved as shown on: the Subcontract Drawings, and as specified in these Specifications as directed by the site Manager, including the removal and disposal of all the resulting materials.

B. Separate payment will not be made for clearing and grubbing at the processing sites nor at Vicinity Properties shown on the subcontract Drawings. Full compensation for such work will be considered to be included in the applicable related item of work specified elsewhere in the subcontract Documents or incidental to the subcontract.

C. Separate payment will not be made for any other work specified in this section. Full compensation for such work will be considered to be included in the applicable relared item of work specified elsewhere in the subcontract Documents or incidental to the subcontract.

END OF SECTION 02110

Ducument No. 3885-RFL-S-01-00739-04

Issued for Construction-Revision 1

RFI-PH-II

site clearing 


\title{
SECTION 02141
}

\author{
DEWATERING AND DRAINAGE
}

\section{PART 1 - GENERAL}

\subsection{SCOPE}

A. This specification section describes the requirements for the disposal of surface and subsurface water from the work areas, and for the design, construction and maintenance of dewatering and drainage facilities.

B. Surface drainage systems as shown on the subcontract Drawings consist of the minimum required drainage ditches, dikes, and wastewater retention basins. The subcontractor shall augment the system by designing and constructing additional features including temporary and permanent ditches, pipes and the like, as required by conditions encountered during the work or by the subcontractor's methods for performing the work. These augmentations shall be in accordance with the contractor-provided discharge permit.

c. If the groundwater level is higher than the bottom of excavation, the subcontractor shall dewater the excavation, as required, for performance of work in the dry. [Stormwater shall be removed from the excavation to maintain dry conditions during excavation and backfill placement.

D. A dewatering scheme for work in uncontaminated areas is not shown on the subcontract Drawings. The subcontractor shall, as required, design and construct additional gravity or pump systems or a combination of both systems for dewatering uncontaminated work areas.

E. A gravity dewatering scheme for work in contaminated areas is limited to the temporary drainage ditches as shown on the Subcon:ras: Drawings. The subcontractor shall, as required, design and construct additional gravity or pump systems for dewatering contaminated work areas.

F. Contaminated material excavation done prior to the construction of the temporary ditches and ratention basins will be diked to prevent runoff from the processing sites.

G. The Subcontractor shall schedule his work to minimize dewatering of contaminated areas. To prevent overloading of the wastewater treatment plants in cases of flooding in 
contaminated areas, the subcontractor shall allow the flood waters to subside before dewatering.

\subsection{EXISTING FACILITIES}

The wastewater retention basins and some drainage ditches on the Old Rifle and New Rifle Processing sites constructed under RFL-PH-I subcontract are shown on the subcontract Drawings as existing features. The subcontractor shall, if required, integrate these features as parts of his dewatering and drainage facilities.

\subsection{DESCRIPTION}

A. The work of this section includes, but is not limited to: dewatering the excavations by installing sump pumps in the excavations and disposal of water by excavating drainage ditches. Water from uncontaminated areas shall be pumped, or allowed to flow by gravity, to designated discharge points leading to the existing drainage courses that flow offsite. Water from contaminated areas shall be pumped, or allowed to flow by gravity, to drainage ditches leading to the wastewater retention basin.

B. The subcontractor shall be responsible for designing, scheduling, utilizing, providing, and maintaining any dikes, ditches, channels, flumes, drains, culverts, sumps, pumping equipment, monitoring weIls, other subsurface dewatering devices, and other temporary diversion and protective work necessary to ensure that construction shall be performed in areas free from water and in accordance with all applicable permits.

\subsection{WORK NOT INCLUDED}

Drainage work related to the construction of temporary facilities specified in section 01500 is not included in the scope of work of this section.

\subsection{RELATED WORK}
A. Section 02168 - Slurry Trench
B. Section 02200 - Earthwork
c. Section 02771 - Membrane Lirier

Document No. 3885-RFL-S-01-00740-04

Issued for Construction-Revision 1

Dewatering and Drainage 
PART 2 - PRODUCTS

2.1 MATERIALS AND EQUIPMENT

The Subcontractor shall furnish all materials, equipment and appurtenances required for furnishing, installing, maintaining and removing dewatering facilities, and shall also supply sufficient standby pumping and auxiliary equipment to preclude any interference to pumping operations during periods of breakdown and maintenance.

\section{PART 3 - EXECUTION}

\subsection{DEWATERING PROCEDURES}

A. Water from uncontaminated areas shall be pumped, or allowed to flow by gravity to natural drainage courses that flow offsite only if said drainage courses are tributary to the outfall locations specified in the discharge permit.

B. All water from contaminated areas including storm runoff will be considered contaminated and shall be either pumped or allowed to flow by gravity to nearby drainage ditches leading to wastewater retention basins. Water from the wastewater retention basins shall not be used for dust and moisture control in uncontaminated fills or in uncontaminated roads. silt fences may also be required in some areas during excavation.

c. The water level in the excavation shall be maintained below the lowest point in the excavation during the backfill of the excavation, unless otherwise approved by the contractor.

\subsection{WASTEWATER RETENTION BASINS AND DRAINAGE DITCHES}

A. Wastewater retention basins and drainage ditches shown on the subcontract Drawings shall be constructed as specified in Section 02200 .

B. Additional drainage ditches, if required, shall be constructed by the subcontractor for collection of contaminated wastewater into the retention basins or to divert uncontaminated water offsite.

\subsection{MAINTENANCE}

The Subcontractor shall be responsible for the maintenance of drainage facilities including, but not limited to, existing facilities during the term of the subcontract. Drainage

Document No. 3885-RFL-S-01-00740-04

Issued for Construction-Revision 1 Dewatering and Drainage 
ditches and pipes may require periodic cleaning. Pipes and ditches shall be kept free of sediment deposits, debris and other materials that may restrict or prevent drainage. The subcontractor, when directed by the Contractor, shall remove and replace all items not functioning properly because of clogging, damage, or deterioration. [Sediments shall be removed from the wastewater retention basins and recycle basins as required by the contractor.]*

\subsection{REMOVAL}

A. When no longer required for water control:

1. Dewatering equipment shall be removed and disposed of as subcontractor's property.

2. Contaminated sediments deposited in ditches and all lined basins shall be removed and disposed of in the tailings embankment as specified in section 02200 and as required by the contractor.

3. Areas occupied by the wastewater retention basins, dikes, spillways, and temporary drainage ditches shall be restored and graded as specified in section 02200 .

\section{PART 4 - MEASUREMENT AND PAYMENT}

\subsection{MEASUREMENT}

Separate measurement for payment will not be made for dewatering and drainage.

\subsection{PAYMENT}

Separate payment will not be made for dewatering and drainage. Full compensation for such work will be considered to be included in the applicable related items of Work specified in this subcontract.

END OF SECTION 02141

* P.I.D. 06-S-17 


\section{PART 1 - GENERAL}

\subsection{SCOPE}

A. This specification section covers the requirements for constructing a leachate collection and removal system as part of the tailings embankment. The work includes the furnishing of all labor, material, transportation, tools, fuel, lubricants, plant and other equipment necessary to construct the leachate collection and removal system. The work also includes pumping the leachate to the retention basin as needed and maintaining the system for the duration of the subcontract.

B. The leachate collection and removal system consisting of a sand and gravel blanket, rock drains, filter fabric, and monitoring wells and piping shall be constructed to the lines and grades shown on the subcontract Drawings.

c. The subcontractor shall provide the necessary pumps and piping for pumping the leachate into the retention basin.

\subsection{RELATED WORK}

A. Special Conditions:

1. Section $\mathrm{SC}-7$ - Construction Environment, Safety and Health

2. Section SC-8 - Health Physics

B. Section 02200 - Earthwork

c. Section 02278 - Erosion Protection

1.3 APPLICABLE PUBLICATIONS

The publications listed below form a part of this specification to the extent referenced. The publications are referred to in the text by the basic designation only:

Document No. 3885-RFL-S-01-03681-01

Issued for Construction-Revision 1

Leachate Collection and Removal System 8544S/WP51 
1. American Society for Testing and Materials (ASTM):

D2665-89a Polyvinyl Chloride (PVC) Plastic Drain, Waste, and Vent Pipe and Fittings

\subsection{SUBMITTALS}

For general submittal requirements see section 01300 .

1.5 DELIVERY, STORAGE, AND HANDLING

Filter material may be delivered to the site in bags or in bulk. The material shall be placed on a protective sheet to prevent contact between it and the ground and shall be protected by impermeable covering.

\section{PART 2 - PRODUCTS}

\subsection{MATERIALS FOR ROCK DRAINS AND BLANKETS}

A. Drain Rock: The drain rock materials described below pertain to both finger and collector drains. Drain rock material shall be clean washed drain rock which shall not contain more than 5 percent by weight of limestone and/or dolomite. The drain rock material shall have the following gradation:

$$
\begin{gathered}
\text { U.S. Standard } \\
\text { Sieve Size } \\
\text { (Square openings) }
\end{gathered}
$$

$$
\begin{aligned}
& \text { 1-1/4-inch } \\
& \text { 1-inch } \\
& \text { 3/4-inch }
\end{aligned}
$$

\author{
Percent Passing \\ (by Weight)
}

$$
\begin{aligned}
& 100 \\
& 0-85 \\
& 0-5
\end{aligned}
$$

B. [Blanket Materials: The material for the blanket shall be clean sand and gravel reasonably well graded within the same limits as drain material Type D2, as specified in section 02278]$.

c. Source Quality control: The materials shall be inspected and tested by the subcontractor at the borrow area to ensure that they meet all requirements of this specification. Gradation requirements will be tested by the contractor at the placement location. [Testing shall be in accordance with specification section 02278 with the added requirement that these materials shall not contain more than 5 percent by weight of limestone and/or dolomite.]*

P.I.D. 06-S-17

Document No. 3885-RFL-S-01-03681-01

Issued for Construction-Revision 1

Leachate Collection and Removal System 85445/WP51 
D. Well casing: The dewatering well casings shall consist of schedule 40 rigid PVC plastic pipe of diameters and lengths as shown on the subcontract Drawings.

E. Filter Fabric: prior to placing the drain rock material in the excavated trench, the trench bottom and sides shall be lined with a filter fabric having the following properties:

\section{Parameter}

Puncture Resistance

(Rod Puncture)

Puncture Resistance

(CBR Puncture)

Tensile Elongation

Effective Opening (Size $D_{w}$ )

Thickness

$\left(t_{g}\right.$ at $\left.0.3 \mathrm{psi}\right)$

Permeability (normal

to plane $k_{v}$ at $0.3 \mathrm{psi}$ )
Standard

ASTM D751*

(Modified)

DIN 54307

(CBR)

ASTM D4595

CW02215)

ASTM D1777

Constant Head

Permeability
Requirement

$1501 \mathrm{bf}$

$7401 \mathrm{bf}$

50-90 percent

$0.07 \mathrm{~mm}$

$125 \mathrm{mil}$

$40 \mathrm{~cm} / \mathrm{s}$ $\left(\times 10^{-2}\right)$

* ASTM D751, modified using a 5/16-inch diameter steel rod with hemispherical tip

Note: The values stated in this table are typical average values.

\section{PART 3 - EXECUTION}

3.1 SAND AND GRAVEL BLANKET CONSTRUCTION

The sand and gravel blanket shall be placed on the excavated foundation surface to the lines and grades shown on the Subcontract Drawings. Compaction of the blanket materials, other than that achieved during the placement operation shall not be required. Separation of the materials into coarser and finer aggregates will not be permitted.

Document No. 3885-RFL-S-ÔI-0̂368I-ÔI.

Issued for construction-Revision 1 
3.2 ROCK DRAIN CONSTRUCTION - FINGER DRAINS AND COLLECTOR DRAINS

A. General: The rock-filled drains shall be installed as follows:

1. The trenches for the finger drains shall be [excavated into the drain blanket or into sand tailings]* which have already been placed and compacted to at least 90 percent dry density. [The trenches for the collector drains shall be excavated into the drain blanket or the sand tailings which have already been placed and compacted.]*

2. If portions of the trenches are located in slimes or sand slimes, as visually determined by the contractor, the sand slimes and/or slimes shall be excavated to the following dimensions and replaced by compacted sand tailings:

a. 6 inches above the top of the trench.

b. Width of the trench plus 5 feet on both sides of the trench.

c. Length of the trench in slimes or sand slimes plus 5 feet.

The ditch shall then be reexcavated to the required grades and dimensions.

3. The drain rock and the surrounding filter fabric shall be installed in trenches. The filter fabric shall be placed around the drain rock and the ends shall overlap at least 6 inches, as shown on the subcontract Drawings.

4. Following placement of the drain rock and the filter fabric, the trench shall be backfilled to 90 percent compaction using the excavated materials. The remaining excavated materials shall be used in the construction of the next lift.

\section{[3.3 CONSTRUCTION DEWATERING] *}

A. The leachate collection and removal system shall be constructed concurrently with the placement of tailings materials in the excavated foundation area of the cell. It is anticipated that the drain system will begin to collect and transport leachate water to the dewatering wells soon after the placement of the first few lifts of contaminated tailings materials.

* P.I.D. 06-S-17

Document No. 3885-RFL-S-01-03681-01

Issued for Construction-Revision 1

Leachate Collection and Removal System 8544S/WP51

RFL-PH-II

$02144-4$

121991 
B. The casings for the dewatering wells shall be extended vertically as the tailings embankment is constructed.

C. A submersible pump with an automatic on-off switch shall be installed in the dewatering well to pump the leachate to the retention basin.

PART 4 - MEASUREMENT AND PAYMENT

\subsection{MEASUREMENT}

A. Measurement for payment for furnishing and installing the sand and gravel blanket will be by the cubic yards of material placed. The quantities for payment will be computed from surveys conducted before and after placement of the blanket.

B. Measurement for payment for the following will be by the linear feet of well casing and rock drain as shown on the Subcontract Drawings and as specified and approved by the Contractor:

1. Furnish and Install Drain Rock and Filter Fabric, including Trench Excavation and Backfill for Finger Drains

2. Furnish and Install Drain Rock and Filter Fabric, including Trench Excavation and Backfill for collector Drains

3. Furnish and Install Monitor Well Casing

c. Measurement for payment for the following will be by the lump sum basis:

1. Furnish and Install submersible Pump and Operation and Maintenance of Leachate Collection and Removal System for Duration of the subcontract

\subsection{PAYMENT}

A. [Payment for the items of Articles 4.1.A and 4.1.B above will be by their applicable unit prices quoted therefor in the Bid Schedule.]*

* P.I.D. 06-S-17 
B. Payment for the item of [Article 4.1.C]* above will be by the lump sum price quoted therefor in the Bid Schedule. Payment shall include full compensation for all operation and maintenance costs including cost of electricity for operating the submersible pump.

C. No separate payment will be made for concrete bases and bentonite seals for the dewatering wells or for other incidentals which are not specifically listed as payment items in the Bid schedule.

D. The prices quoted shall include full compensation for furnishing all labor, materials, equipment, tools, accessories, and incidentals, and for performing all work including installing/constructing, operating, maintaining the leachate collection and removal system, and providing specified services as required, through the term of the subcontract.

END OF SECTION 02144

* P.I.D. 06-S-17

Document No. 3885-RFL-S-01-03681-01

Issued for Construction-Revision 1

Leachate Collection and Removal System

RFL-PH-II

$02144-6$ 
PART 1 - GENERAI

1.1 SCOPE

This specification section covers the requirements for construction of a cutoff wall at the [Old and New Rifle processing sites]* by the slurry trench method as specified herein and as indicated on the subcontract Drawings. The scope of work also includes construction of drainage windows in the slurry trench as specified herein and as shown on the Subcontract Drawings.

\subsection{DEFINITIONS}

A. The terms used in the specifications are defined as follows:

1. Slurry Trench: A vertical walled trench, at least $2-1 / 2$ feet in width, excavated by the slurry trench method, and backfilled with a specified soil and slurry mixture to form a cutoff wall of low permeability.

2. Slurry: A stable colloidal mixture of bentonite and water.

3. Bentonite: A natural ultrafine clay whose principal mineral constituent is sodium cation base montmorillonite.

4. Soil-Bentonite cutoff Wall: The wall formed in the slurry trench as a result of placing a mixture of backfill materials and bentonite in the trench.

5. Ground Water Level: The piezometric level of the ground water as determined from piezometers penetrating the pervious deposits.

6. Working Surface: A compacted earthfill, constructed by the subcontractor to the grades shown on the subcontract Drawings.

* P.I.D. 06-S-17 


\subsection{SPECIAL REQUIREMENTS}

A. Site Conditions: The area to be excavated consists of a heterogeneous mixture of silt, sand, gravel, cobbles and boulders overlying weathered bedrock of the wasatch formation, the latter consisting of alternating strata of siltstone, clayey shale and sandstone.

B. Subcontractor shall review soils data and perform additional tests, if necessary, to be certain that his equipment is fully capable of excavating to grade in accordance with the specifications and the Subcontract Drawings.

c. The subcontractor shall submit evidence of experience and competency in slurry trench construction. To ensure that the subcontractor or his subcontractor will have experienced and competent personnel to carry out all operations as specified, a Mud Engineer or Mud Specialist, experienced in slurry trench construction, shall be utilized to control the mixing, composition, placing, cleaning, and maintenance of the slurry. He shall supervise on a full-time basis the mixing and placing of backfill and ensure that the trench is vertical, properly aligned, and clean prior to the placement of backfill.

D. The Subcontractor shall maintain and control access across the slurry wall during construction in a manner that the wall is not undermined.

\subsection{APPLICABLE PUBLICATIONS}

A. The Publications listed below form a part of this specification to the extent referenced. The publications are referred to in the text by the basic designation only:

1. American Petroleum Institute (API):

RP 13A-1985 specifications for Oil-Well Drilling - Fluid Materials

RP 13B-1985 Recommended Practice Standard Procedure for Field Testing of Drilling Fluids

2. American Society for Testing and Materials (ASTM):

[C136-84 Standard Method for Sieve Analysis of Fine and Coarse Aggregates (Rev. A)

C143-90 Test Method for Slump of Hydraulic Cement Concrete

Document No. 3885-RFL-S-01-02058-03

Issued for Construction-Revision 1 


D1140-54 Standard Test Method for Amount of Mate-
rial in Soils Finer than the No. 200
(75-Micrometer) Sieve (R 1990)]*

\subsection{SUBMITTALS}

A. Sixty days prior to beginning work, the subcontractor shall submit to the contractor for review and approval, the following:

1. A detailed plan, and method of construction for the construction of the slurry trench with a list of equipment and manpower to be used.

2. Four copies of certificate of compliance of bentonite with this specification.

3. Four copies of test results of bentonite.

\section{PART 2 - PRODUCTS}

\subsection{MATERIALS}

A. Bentonite: Bentonite for use in the slurry shall be premium grade unadulterated powdered wyoming sodium cation bentonite conforming to the standards set forth in American Petroleum Institute (API) specification R.P. 13A (American Petroleum Institute, Division of Production, 300 corrigan Tower Building, Dallas, Texas, 75201). No chemically treated bentonite will be allowed.

B. Water: The subcontractor shall supply all water required for mixing slurry. Water used shall have a pH equal to $7.0 \pm 1.0$ and shall have a hardness not greater than $500 \mathrm{ppm}$ as total dissolved solids. Water quality tests shall be performed once on the water from the proposed source prior to mixing the water with bentonite. Additional tests shall be required each time the water source is rhanged. The subcontractor shall perform all necessary tests of the water to determine its acceptability.

* P.I.D. 06-S-17

Document No. 3885-RFL-S-01-02058-03 
c. Slurry:

1. The slurry shall consist of a stable colloidal suspension of bentonite in water. slurry properties shall be determined by API specification R.P. 13B. The subcontractor shall provide all necessary personnel, laboratory facilities, and testing equipment to perform the specified tests.

2. With the prior approval of the Contractor, the properties of the slurry may be altered to suit construction conditions by admixtures used for the control of oil field drilling mud. Under no conditions will peptizing or bulking agents be allowed. All slurry for use in the trench shall be mixed by a plant capable of producing a colloidal suspension of bentonite and water. The plant shall include a mixer, a mechanically agitated sump, pumps, valves, supply lines, and small tools and all equipment as required to supply slurry to the trench. Mixing shall continue until bentonite particles are fully hydrated and the resulting slurry is homogeneous. Slurry may be stored in a slurry pond and shall be transported to the trench by a pipeline or other methods to prevent contamination.

3. The slurry mixture shall consist of a minimum of 20 lbs. of bentonite per barrel (42 gal.) of slurry.

a. Slurry properties at the time of introduction into the trench:

1) Density shall be not less than 65 lbs. per cubic foot nor greater than 85 lbs per cubic foot.

2) Apparent viscosity shall be not less than 15 centipoise or 40-seconds reading through a Marsh Funnel at $68^{\circ} \mathrm{F}$.

3) Filtrate loss shall be not greater than 25 cubic centimeters at $100 \mathrm{psi}$ in 30 minutes.

4) Shear strength shall not be less than $0.07 \mathrm{lb} / \mathrm{ft}$ and not greater than $0.49 \mathrm{lb} / \mathrm{ft}$ as measured by shearometer testing.

b. slurry properties at any time in the slurry trench:

1) Density shall be not less than 65 lbs. per cubic foot nor greater than 85 lbs. per cubic foot.

Document No. 3885-RFL-S-01-02058-03

Issued for Construction-Revision 1 
2) Apparent viscosity shall be not less than 15 centipoise or 40-seconds reading through a Marsh Funnel at $68^{\circ} \mathrm{F}$.

3) Filtrate loss shall be not greater than 35 cubic centimeters at $100 \mathrm{psi}$ in 30 minutes.

4) Shear strength shall not be less than $0.07 \mathrm{lb} / \mathrm{ft}$ and not greater than $0.49 \mathrm{lb} / \mathrm{ft}$ as measured by shearometer testing.

c. If the density of the slurry in the trench exceeds the specified limits, the slurry shall be cleaned of suspended matter by use of stilling ponds, cyclones (desanders) or other appropriate equipment or procedures.

d. Tests to determine the slurry properties in the active trenches shall be made every 200 linear feet of slurry trench and at least, twice a day.

e. Tests shown above shall be documented by the subcontractor.

D. Testing Equipment:

1. The subcontractor shall furnish and maintain test equipment to be used by qualified personnel, provided by the subcontractor, with a working knowledge of test procedures for slurry testing. Applicable Test Procedures shall conform to API Standard 13B, "Standard Procedures for Testing Drilling Fluids".

2. Each test equipment set shall include:

a. One Marsh Funnel viscometer and Measuring Cup (Baroid Nos. $201 \& 202$ or approved equal).

b. One Sand Content set (Baroid No. 400-01 or approved equal).

c. One Filter Press (co Cartridge pressurized system) (Baroid No. 302-01 or approved equal).

d. One "Laboratory Mixer," electric.

e. One stopwatch.

f. Two "Short Range" pH dispensers with paper (Baroid No. 625 or approved equal).

Document No. 3885-RFL-S-01-02058-03

Issued for Construction-Revision 1 


\author{
g. One Mud balance (Baroid No. 140 or approved equal). \\ h. One shearometer.
}

\title{
2.2 BACKFILL MATERIALS
}

A. Backfill materials shall be composed of slurry and select materials from trench excavation and/or materials transported from approved borrow areas. Backfill material shall be uncontaminated material with no more than one percent of organic matter, roots and other deleterious matter. It shall contain between 20 and 40 percent by weight of material passing the U.S. standard No. 200 sieve and not more than 10 percent of material greater than $1-1 / 2$ inches in diameter and, no more than one percent of a size greater than 3 inches in diameter.

B. Backfill materials shall be thoroughly mixed and sluiced with slurry to form a homogeneous mass just prior to the backfilling operation. The mass shall be free from lumps of clay and silt greater than 6 inches in maximum measurement, and pockets of sand, gravel and cobbles. The minimum bentonite content after blending shall be not less than 1.5 percent.

C. A gradation test in accordance with ASTM C136 and D1140 shall be performed for every 500 cubic yards of mixed backfill material, unless indicated otherwise by the contractor.

2.3 DRAINAGE WINDOW MATERIALS

Drainage window materials shall be installed in the slurry wall at [Old and Rifle processing sites]* and shall be well graded uncontaminated materials conforming to the following gradation limits:

U.S. Standard

Sieve size

(square openings)

3-inch

1-1/2-inch

3/4-inch

3/8-inch

No. 4

No. 10
Percent Passing

(by weight)

$$
\begin{gathered}
100 \\
75-90 \\
50-65 \\
30-45 \\
15-30 \\
0-12
\end{gathered}
$$

* P.I.D. 06-S-17

Document No. 3885-RFL-S-01-02058-03

Issued for Construction-Revision 1 
PART 3 - EXECUTION

\subsection{EXCAVATION}

A. Preparation of Working surface:

1. [Old and New Rifle Processing Sites:]* Prior to slurry trench construction, all contaminated materials along the trench alignment, shall be excavated and backfilled with uncontaminated materials. The subcontractor shall schedule the construction of the slurry trench during low water season to allow the maximum removal of the contaminated materials prior to slurry trench construction. [Al] excavated contaminated material along the slurry trench alignment shall be transported to Estes Gulch for disposal at no additional cost to the Contractor.]* A compacted fill working surface shall then be constructed along the slurry trench centerline as shown on the subcontract Drawings. The working surface shall be constructed of compacted materials that will provide adequate support for equipment to be used in the slurry trench construction. The slurry trench shall then be excavated through this compacted fill to the required depth.

2. Excavation of the slurry trench shall be performed with a backhoe or other suitable excavation equipment. Regardless of the method of excavation, a 2-1/2-foot wide continuous trench shall be constructed along the trench centerline penetrating into bedrock as indicated on the subcontract Drawings. At directional changes, or at other tie-in points, minimum overlaps of 10 feet at the bottom of the trench will be required. Subcontractor shall be responsible for documenting that the trench is vertical and continuous and that bedrock is penetrated to the minimum depth shown on the subcontract Drawings.

B. Excavation Procedures:

1. Slurry shall be introduced into the trench at the time trenching is begun.

2. The Subcontractor shall maintain the stability of the trench at all times. Excavated materials shall be dumped at a lateral distance of at least 25 feet on the upstream side of the centerline of the trench to allow the slurry

* P.I.D. 06-S-17

Document No. 3885-RFL-S-01-02058-03

Issued for Construction-Revision 1

Slurry Trench

RFL-PH-II

$02168-7$ 
to flow back into the trench. The height of fall shall not exceed 10 feet above the working surface elevation. Excavated material, deemed not acceptable as backfill material shall be disposed of in an area approved by the Contractor. Under no circumstances shall any materials be dumped in the rivers or streams in the area.

3. The level of the slurry in the trench shall be maintained at a minimum of 2 feet above ground water level at the time of installation and a maximum of 1 foot below the top of the working surface. If the ground water (or river surface) should reach within 3 feet of the working surface and be rising, excavation shall cease and the trench shall be temporarily backfilled. Excavation may again proceed when ground water level recedes to acceptable levels as determined by the contractor. If time precludes backfilling with approved materials, Subcontractor shall re-excavate all temporary backfill. In order to ensure quality and continuity of backfill, subcontractor shall, in all abandonment cases, reexcavate a segment of the permanent backfill. This segment shall be a line paralleling and extending 25 feet (measured horizontally) into the former approved backfill slope. If abandonment of slurry trench excavation, due to high water (or river level) does occur and the subcontractor is ordered by the contractor to backfill the trench, he will be reimbursed for extra work necessitated by this suspension of construction operations.

c. As directed by the contractor the subcontractor shall take soundings when bedrock is first encountered. He shall continue excavating until the required minimum penetration into the bedrock is achieved as determined by the contractor. Soundings of the bottom of the trench shall be taken for every 50 feet of the wall. Whenever possible, the contractor will verify that adequate depth has been achieved.

\subsection{BACKFILL}

A. The mixed backfill at the time of introduction into the trench shall have a slump between 4 inches and 7 inches as determined by the slump test conforming to ASTM C143. One test for every 200 feet of slurry wall, and at least, two tests per day shall be performed. The subcontractor shall provide the mold for the slump test and shall perform the test in the presence of the contractor.

B. Free dropping of backfill into the trench will not be permitted. Initially the backfill shall be lowered to the

Document No. 3885-RFL-S-01-02058-03

Issued for Construction-Revision 1 Slurry Trench

RFL-PH-II

$02168-8$ 
bottom of the trench and deposited by means of a lead-in trench. Backfill operations shall proceed in this manner until the backfill emerges above the slurry working surface and until its natural angle of repose is achieved from the bottom of the trench.

C. Subsequent backfill operations shall proceed in such a manner that the slope of the initial backfill will be maintainad. The new backfill material will be allowed to slide down the slope of the previously placed backfill, and shall be placed in such a manner that pockets of slurry will not be trapped during subsequent backfill operations. Bulldozers or other approved equipment may be used to accomplish the task.

D. Backfill operations shall be suspended on days when the ambient temperature falls below $25^{\circ} \mathrm{F}$.

\subsection{TREATMENT OF TOP OF SLURRY TRENCH}

The top of the completed slurry trench shall be covered by a compacted 3-foot layer of clay material (surcharging) as a protective layer to prevent drying. The trench shall be covered within 72 hours after the backfill reaches the top of the slurry trench, and the trench allowed to settle and stabilize for at least 14 days. Equipment traffic and other construction activity shall not be allowed on top of the wall until it is stabilized.

\subsection{END OF CONSTRUCTION}

A. General: The subcontractor shall plan and execute the work to minimize the need for disposal of excess material and wastes. Excess slurry from ponds and trench, debris, and litter shall be disposed of at locations approved by the contractor.

B. All contaminated soil shall be stockpiled at the tailings pile.

c. Prior to restoration of the site to the final grades, the backfill material in the slurry trench will be tested to determine whether the material is contaminated, and if so to what extent.

D. If the Contractor determines that the contamination level of the backfill material in the slurry trench is above acceptable limits, the subcontractor will be advised to remove a part or the whole slurry wall. The subcontractor

Document No. 3885-RFL-S-01-02058-03

Issued for Construction-Revision 1 
shall plan his construction sequence and operations to allow for such removals of the slurry wall, if required.

E. In the event that removal of the slurry wall is not required by the contractor, the subcontractor shall construct "drainage windows" across the trench alignment as shown on the Subcontract Drawings. The "drainage windows" shall be constructed prior to commencement of the earthwork placement activities for site restoration. The backfill material removed from the trench shall be disposed of at locations approved by the contractor.

F. The backfill material on the railroad right-of-way and above the existing ground surface shall be removed prior to site restoration.

G. The final grade shall be at least 3 feet above the top of the slurry trench backfill level. In the event the backfill level is less than 3 feet (including situations where the top of the trench has to be cut to achieve finished grade), the top of the trench shall be prepared as shown on the subcontract Drawings.

\section{PART 4 - MEASUREMENT AND PAYMENT}

\subsection{MEASUREMENT}

A. Measurement for payment for construction of slurry trench at [Old and New Rifle processing sites]* will be by the longitudinal area in square feet of completed slurry trench, projected on a vertical plane from the working surface to the bottom of the trench along the centerline of the trench. Measurements shall be based on soundings of the trench.

B. Separate measurement for payment will not be made for the following:

1. Tie-in locations.

2. Construction of drainage windows.

3. Surcharge materials for slurry wall.

4. Stockpile and transport to Estes Gulch of contaminated materials along the slurry trench alignment at old and New Rifle.]*

* P.I.D. 06-S-17 


\subsection{PAYMENT}

A. Payment for construction of slurry trench at [Old and New Rifle processing sites]* will be by the unit price per square foot quoted therefor in the Bid schedule. The price quoted shall include full compensation for furnishing all materials, labor, equipment, tools, accessories, incidentals and for performing all work including excavating, furnishing bentonite and water, mixing and placing of slurry, removal of slurry if required, preparation and placement of backfill, surcharging, and cleanup operations.

B. Separate payment will not be made for the items mentioned in Article 4.1.B. Full compensation for such work will be considered to be incidental to the above items of work.

END OF SECTION 02168

* P.I.D. 06-S-17

Document No. 3885-RFL-S-01-02058-03 


\section{SECTION 02200}

EARTHWORK

PART 1 - GENERAL

\subsection{SCOPE}

A. This specification section covers earthwork for, or related to, the following:

1. Excavation and stockpiling of uncontaminated materials from the tailings embankment foundation at the Estes Gulch Disposal site.

2. Excavation of contaminated materials from the two processing sites and construction of the tailings embankment at the disposal site.

3. Removal and disposal of existing stockpiles of demolished materials and debris in the construction of the tailings embankment.

4. Removal of demolished materials and debris resulting from work specified in section 02050 and placement in the construction of the tailings embankment.

5. Handling and disposal of contaminated vicinity property materials delivered to the New Rifle site by others and placement in the construction of the tailings embankment.

6. Handling and disposal of existing stockpiles and containers of asbestos, hazardous and non-hazardous waste materials in the tailings embankment.

7. Construction of temporary and permanent drainage ditches and wastewater retention basins. Quality assurance and quality control provisions specified in this section will not be applicable to temporary drainage ditches.

8. Finish grading of the sites, including restoration and regrading of drainage ditches, wastewater retention basins, contaminated water recirculation ponds, sumps, and temporary facilities areas.

Document No. 3885-RFL-S-01-00741-04

Issued for Construction-Revision 1 
9. Furnishing and placing of imported uncontaminated fill material from subcontractor's source(s) as backfill at old and New Rifle Sites.

10. Excavation of the foundation for the Estes Gulch Disposal Cell and stockpiling of excavated material for use as radon barrier and frost cover.

11. Furnishing and placing of cover materials at Estes Gulch.

12. Furnishing and placing radon barrier with and without bentonite amendment and frost barrier at Estes Gulch.

13. Borrow area development and restoration.

[B. This specification section covers furnishing and installing displacement monuments as shown on the subcontract Drawings. ]*

\subsection{WORK NOT INCLUDED}

A. Earthwork related to the construction of offsite temporary facilities specified in section 01500 is not included in this Section.

B. Earthwork for pipe trenches is not included in this section.

1.3 RELATED WORK

A. Section 00800 - Special Conditions: Definitions

B. Section 01300 - submittals

C. Section 01500 - Construction Facilities

D. Section 02050 - Demolition

E. Section 02141 - Dewatering and Drainage

F. Section 02278 - Erosion Protection

G. Section 02935 - seeding

1.4 DEFINITIONS

A. Contaminated materials and uncontaminated materials are defined in Article SC-1 of the special Conditions.

* P.I.D. $06-S-17$ 
B. Common Excavation: Common excavation shall include excavation of all materials encountered regardless of the nature of the materials, including topsoil, silt, clay, sand, gravel, talus, soft or disintegrated rock, boulders or detached pieces of solid rock, and rippable rocks (as defined below). Common excavation shall be further classified into the following categories:

1. Contaminated Materials Excavation.

2. Uncontaminated Materials Excavation.

c. Contaminated Materials Excavation: Contaminated materials excavation shall include excavation of contaminated materials from the existing tailings pile, windblown areas, evaporation ponds, the wastewater retention basins, the washwater recirculation ponds, and any other contaminated areas identified by the contractor.

D. Uncontaminated Materials Excavation: Uncontaminated materials excavation shall include excavations of uncontaminated materials from the various areas of the sites including, but not limited to, excavations for embankment, drainage ditches, retention basins, trenches, and finish grading.

E. Overexcavation: Overexcavation is defined as (1) excavation carried out beyond the lines and grades indicated on the Subcontract Drawings or (2) excavation carried out beyond the authorized limits set by the contractor.

F. Sands: The coarse fraction of the tailings defined as containing less than 30 percent passing the No. 200 sieve.

G. Sand Slimes: A mixture of sand and slimes defined as having not less than 30 or more than 70 percent passing the No. 200 sieve.

H. Slimes: Slimes are the fraction of the tailings consisting of silty clay, clay and clayey silt, defined as containing more than 70 percent passing the No. 200 sieve.

I. Percent Maximum Density: Percent maximum density is a percentage of the maximum dry density obtained by the test procedure presented in ASTM D698.

J. Topsoil: See section 02110 .

K. Tailings Embankment: Tailings embankment shall consist of relocated contaminated materials and any other contaminated materials from the tailings piles, evaporation ponds, windblown areas, vicinity property materials, sediments from 
wastewater retention basins, demolished materials and debris, and the protective cover materials placed and compacted as shown on the subcontract Drawings and as specified in this section.

L. Subgrade Preparation: Subgrade preparation includes fine grading and compaction of excavations including drainage ditches, backfills, and embankments upon which bedding materials, riprap, filters or other features are to be constructed.

M. Cover: Cover shall consist of the layers of following fill materials placed over the relocated contaminated materials in the tailings embankment as shown on the subcontract Drawings:

1. Drainage materials and riprap materials. (See section 02278$.

2. Radon barrier material.

3. Frost barrier material.

N. Stockpiles of Demolished Materials and Debris: Existing stockpiles of demoiished materials and debris consist of pieces of wood, concrete, masonry, steel members and demolished materials and debris resulting from demolition work specified under this subcontract.

o. Vicinity Properties Materials: These are contaminated materials from areas other than the processing site.

P. Handling and Placing of Vicinity Property Materials: This shall include loading, hauling, spreading, moisture conditioning and compacting contaminated vicinity property materials on the tailings embankment area.

Q. Finish grading shall include excavation and backfill of the various areas of the site including backfilling of evaporation ponds, retention basins, temporary drainage ditches, contaminated water recirculation ponds, sumps, and temporary facilities areas as shown on the subciontract Drawings.

R. Temporary Drainage Ditches: Temporary drainage ditches shall include temporary diversion and collector ditches as shown on the Subcontract Drawings.

s. Permanent Drainage Ditches: Permanent drainage ditches shall include interceptor and toe ditches shown on the subcontract Drawings.

Document No. 3885-RFL-S-01-00741-04

Issued for Construction-Revision 1 
T. Stockpiles and Containers of Asbestos, Hazardous and NonHazardous Materials: These are materials removed from the mill buildings and facilities and stockpiled and containerized on site for transport and disposal into the tailings embankment by subcontractor.

U. Rippable Rock: Rippable rock is defined as mineral matter in place and of such hardness and texture that it can be effectively loosened or broken down by ripping in a single pass with a late model tractor-mounted hydraulic ripper equipped with one digging point of standard manufacturer's design adequately sized for use with and propelled by a D10 bulldozer, or approved equal crawler-type tractor rated at a minimum of 500-net flywheel horsepower, operating in low geár.

V. Frozen Material or Subgrade or Foundation: Material or Subgrade or Foundation that has a temperature below freezing and generally contains a variable amount of water in the form of ice.

พ. Average Seasonal High Groundwater Elevations: Monitor wells located in the alluvium of the old and New Rifle processing sites indicate that the maximum seasonal high groundwater elevations occur during the month of June. The reference groundwater elevations based on contour maps developed from water level data from the monitoring well networks at the two sites are:

1. At Old Rifle Processing site = El. 5305 feet

2. At New Rifle Processing Site = El. 5263 feet

These elevations are average figures and may vary significantly from year to year.

1.5 APPLICABLE PIJBIICATIONS

A. The Publications listed below form a part of this specification to the extent referenced. The Publications are referred to in the text by the basic designation only:

1. American Association of State Highway and Transportation officials (AASHTO):

T99-86 Moisture-Density Relations of Soils Using a 5.5-1b. (2.5-kg) Rammer and a 12-in. (305mm) Drop

Document No. 3885-RFL-S-01-00741-04

Issued for Construction-Revision 1

Earthwork 
T180-86 Moisture-Density Relations of Soils Using a 10-1b. (4.54-kg) Rammer and a 18-in. (457$\mathrm{mm})$ Drop

2. American Society for Testing and Materials (ASTM) :

C136-84 Standard Method for Sieve Analysis of Fine and Coarse Aggregates (Rev. A)

D422-63 Standard Method for Particle-size Analysis of Soils

D698-78 Test Methods for Moisture-Density Relations of Soils and Soil-Aggregate Mixtures Using 5.5 1b. (2.49-kg) Rammer and 12-in. $(305-\mathrm{mm})$ Drop

D1140-54 Standard Test Method for Amount of Material in Soils Finer than the No. 200 (75-um) Sieve (R 1971)

D1556-82 Test Method for Density of Soil in Place by the Sand-Cone Method

D2167-84 Test Method for Density and Unit weight of soil In-Place by the Rubber-Balloon Method

D2216-80 Test Method for Laboratory Determination of Water (Moisture) Content of soil, Rock, and Soil-Aggregate Mixtures

D2922-81 Test Methods for Density of Soil and SoilAggregate in Place by Nuclear Methods (Shallow Depth)

D3017-78 Test Method for Moisture Content of Soil and Soil-Aggregate in Place by Nuclear Methods (Shallow Depth)

D4643-87 Standard Test Method for Determination of Water (Moisture) Content of soil by the Microwave Oven Method

1.6 QUALITY ASSURANCE

A. The contractor will take soil samples and perform moisture-density tests and particle size determinations to ascertain that the work is being performed in compliance with these specifications. Samples may be taken on the fill itself. The contractor will conduct the density and other tests on the fill and related laboratory testing as

Document No. 3885-RFL-S-01-00741-04

Issued for Construction-Revision 1 
frequently as the Contractor considers necessary. The Subcontractor shall remove surface material and render assistance as necessary to enable sampling and testing to be carried out.

B. Methods of Sampling and Testing:

1. Particle size Analysis: ASTM D422 and ASTM C136

2. Percentage Passing No. 200 Sieve: ASTM D1140

3. In-Place Density: ASTM D1556, D2167, or D2922

4. Laboratory Moisture Content: ASTM D2216, D4643

5. Laboratory Moisture-Density Relations: ASTM D698

6. In-Place Moisture Content: ASTM D3017

c. Suitability of Materials: The suitability of all materials for foundations and backfill will be determined by the Contractor. Fill material shall be approved material from borrow areas or required excavations. [The suitability of radon barrier and frost barrier materials will be determined by the contractor during cell excavation activities at Estes Gulch. The subcontractor shall stockpile these materials in separate areas.]*

D. The subcontractor shall make his own determination of any processing that may be required, and shall perform testing as required to ensure that the materials meet the specification requirements.

E. The Contractor may direct that inspection trenches or test pits be cut into fjlls to determine that the specifications have been met. Such trenches or pits will be of limited depth and size, and shall be backfilled with the material excavated therefrom, or other fill material meeting the requirements for the zones cut into. Backfill shall be compacted to a density at least equal to that specified for adjacent fills.

F. When the contractor directs inspection trenches or test pits to be excavated into fills and backfills and materials are found to meet all specification requirements, the excavation and refilling shall be paid for as additional work pursuant to the applicable provisions of the General Conditions. Inspection trenches or test pits, and the refilling of the same, shall be at the Subcontractor's expense when it is found that the materials do not meet the specification requirements.

G. Tolerances: See Specification Section 01052, [Article 1.8]*.

* P.I.D. 06-S-17

Document No. 3885-RFL-S-01-00741-04

Issued for Construction-Revision 1 


\subsection{SUBMITTALS}

A. General submittal requirements are specified in section 01300 .

B. The subcontractor shall submit to the contractor for approval, 15 days before he intends to dispose of any material in the spoil area, a plan showing the layout of his proposed activities. The plan shall show: location of rock spoil, location of excavated material, stockpile for topsoil, layout of sediment traps, and other measures for pollution control.

\subsection{PROTECTION}

A. The subcontractor shall preserve and protect the following:

1. Trees, shrubs and other features remaining as a portion of final grading.

2. Bench marks and monuments, existing structures, fences, walks, pavings, curbs, etc. from equipment and vehicular traffic.

3. Utilities not specified for removal.

4. Excavations from cave-in by shoring, bracing, sheetpiling, underpinning or by other methods.

5. Excavation surfaces from frost prior to placing any fill or concrete on such surfaces.

6. Perimeter of excavations to prevent surface water runoff into excavation.

7. Monitor wells not to be sealed or demolished.

8. Radon barrier materials that are placed prior to winter shutdown.

9. Protection of plant species Astragalus Wetherilli along the haul road from Highway 13 to Estes Gulch.

10. Sites defined in the report on Threatened and Endangered species.

11. Archaeological areas encountered during the work. 
2.1 UNCCNTAMINATED FILL MATERIALS

\section{A. General:}

1. Uncontaminated fill material shall further be divided into the following categories:
a. General Fill - imported
b. Coarse Fill - imported
c. Radon Barrier Material
d. Radon Barrier Material amended with Bentonite
e. Frost Barrier Material
f. Topsoil Material

Radon barrier materials shall be obtained from the designated borrow areas. Gravel fill materials shall be furnished by the subcontractor.

2. Fill materials shall be obtained from required excavations to the extent available. The materials excavated from one site shall be used as fill or backfill for finish grading of the other sites. Where the excavated materials do not meet the requirements of the specifications or they are not available, the materials shall be furnished from subcontractor's borrow areas.

3. Submittals for approval of sources proposed for use by the subcontractor shall include boring logs, borrow area maps and supporting laboratory test data. The subcontractor also shall provide evidence of availability, right of access to private property including access by the contractor for sampling and testing, and his plan for hauling the materials to the site. Submittals for approval of sources for uncontaminated fill materials shall be received by the contractor at least 60 days before use of the material at the site. The Contractor may perform additional tests to determine if the materials meet the requirements specified herein.

4. Approval will be based on evidence of compliance with the requirements specified herein and on verification by the subcontractor that the volume of materials available is sufficient for construction requirements. 
5. Uncontaminated fill materials for top 6 inches of fill used in finish grading of the sites shall be a mixture of 50 percent topsoil and 50 percent generally fine grained excavated uncontaminated materials.

6. Uncontaminated fill materials for common/general fill to be used as (i) fill or backfill below the top 6 inches of fill used in finish grading of the sites and as (ii) frost barrier fill for the tailings embankment cover shall conform to the following requirements:

a. Uncontaminated common/general fill material shall not contain deleterious substances of more than 5 percent organic material by volume.

b. Maximum particle size shall not be greater than three-fourths $(3 / 4)$ the compacted lift thickness in any dimension, except as noted hereinafter. Individual large stones shall be distributed within the fill materials to provide visual voidfree mass, and be able to meet the requirements of Article 3.8 .

B. Radon Barrier Materials: Radon barrier materials shall consist of uncontaminated materials obtained [Text Deleted]* in the excavation of [the tailings embankment]* foundation and the toe ditch at the Estes Gulch disposal site. [Approximately 2/3 of the uncontaminated materials to be used for construction of the radon barrier shall be mixed with bentonite.]* The materials shall conform to the following requirements :

1. Materials shall consist of soils with 95 percent finer than 1 inch and with a maximum size of 3 inches. In addition, materials shall consist predominantly of soils with a minimum of 60 percent passing [the No. 200 sieve]* and shall be free from deleterious substances and with not more than one percent by volume of organic matter. For the purpose of this subcontract, the word "predominantly" shall mean that at least four test results out of each consecutive five test results shall indicate a minimum of 60 percent passing [the No. 200 sieve]* and one test out of five excluding retests may have not less than 40 percent passing the No. 200 sieve. [Material testing for percentage passing or retained on specified sieves shall be in accordance with ASTM C136, D422 and D1140. Compliance with these specifications will be determined by the contractor.]*

* P.I.D. 06-S-17

Document No. 3885-RFL-S-01-00741-04

Issued for Construction-Revision 1

Earthwork

RFL-PH-II

$02200-10$

5432 S/WP51

121991 
2. Radon barrier materials shall be screened or otherwise processed to reduce clod sizes to 1 inch or smaller prior to mixing with bentonite and moisture conditioning.

\section{Bentonite:}

a. Bentonite shall be a wyoming sodium bentonite as obtained from H\&H Bentonite, Grand Junction, Colorado, or an approved equal supplier.

b. Subcontractor shall submit test results or manufacturer's certificate stating that the bentonite conforms to the requirements of specification $13 \mathrm{~A}$ of the American Petroleum Institute. The contractor reserves the right to inspect the manufacturer's facilities and verify the quality of the bentonite. Test results or manufacturers certificate shall be submitted for each lot or shipment of bentonite in accordance with section 01300 .

c. Frost Barrier Materials: Frost barrier materials shall consist of materials obtained from excavation of tailings embankment foundation and other excavated material from the Estes Gulch Disposal site.

D. Topsoil shall be stockpiled separately and shall not be used for radon barrier or frost barrier.

E. Imported Uncontaminated Fill Macerials: Imported uncontaminated fill materials shall be obtained from the subcontractor's sources. Imported uncontaminated fill materials shall be as specified in Paragraph 2.1.A above, and in addition, shall meet the applicable requirements as follows:

1. General Fill: Conform to Article 2.1.A above.

2. Coarse Fill:

a. Coarse fill materials to be placed in dewatered excavations extending below the elevation of the average seasonal high groundwater (see Article 1.4 for definition of seasonal high groundwater) at old Rifle and New Rifle processing sites shall be reasonably well graded within the limits shown below when determined in accordance with ASTM D422 and ASTM C136.

Document No. 3885-RFL-S-01-00741-04

Issued for Construction-Revision 1 
U.S. standard

sieve size

(square openings)

Coarse Fill
Percent Passing

(by weight)

$$
\begin{array}{lc}
18-i n c h & 100 \\
1-1 / 2-i n c h & 50-100 \\
\text { No. } 200 & 0-25
\end{array}
$$

b. Coarse fill materials shall be obtained from natural sand and gravel deposits with less than 5 percent by weight of deleterious materials, including clay lumps, friable particles, and organic matter.

\subsection{CONTAMINATED FILL MATERIALS}

Contaminated materials defined in Article SC-1 of the Special Conditions resulting from the clearing, stripping and excavation operations in contaminated areas. These materials shall include materials excavated from tailings pile, evaporation ponds, windblown areas, contaminated sediments from drainage ditches and wastewater retention basins, sumps and recirculation ponds and any other areas designated by the contractor including vicinity properties, demolished materials and debris.

\subsection{DEMOLISHED MATERIALS AND DEBRIS}

A. Contaminated demolished materials and debris stockpiled onsite by others shall be placed in the tailings embankment.

B. Contaminated demolished materials and debris resulting from work specified under section 02050 shall be placed in the tailings embankment.

\subsection{VICINITY PROPERTIES MATERIALS}

Vicinity properties materials delivered to the New Rifle site shall be loaded, hauled and placed in the tailings embankment. 


\subsection{ASBESTOS, HAZARDOUS AND NON-HAZARDOUS MATERIALS}

Existing stockpiles and containers of asbestos, hazardous and non-hazardous waste materials stored on the processing sites shall be transported to the disposal site and placed in the lower lifts of the tailings embankment as directed by the Contractor.

\subsection{EQUIPMENT}

A. Vibratory rollers specified for compaction of gravel fill in [Article 3.5.D.8] * shall have a total static weight of not less than 20,000 pounds with at least 90 percent of the weight transmitted to the ground through a single smooth steel drum when the roller is in a level position. The diameter of the drums shall be a minimum of five feet and a maximum of five feet and six inches, and the width shall be a minimum of six feet and be equipped with suitable cleaning devices to keep them free of any accumulation of material. The frequency of vibration during operation shall be between $18 \mathrm{cps}$ and $25 \mathrm{cps}$ and the dynamic force applied by the roller shall be not less than 40,000 pounds at the operating frequency. The roller shall be self-propelled or suitable for towing by a crawler tractor with a minimum drawbar rating of 50 horsepower at speeds not exceeding three miles per hour. A Koehring/Bomag Model BWlos Vibratory Roller (tractor-towed), or approved towed or self-propelled equal shall be used. Prior to the use of a vibratory roller in the work, the subcontractor shall furnish manufacturer's data, drawings, and computations to verify compliance with the above specifications for approval by the contractor.

B. Mixer: The mixer for mixing bentonite with the radon barrier material shall be capable of thoroughly mixing and controlling the percentage, by weight, of bentonite, soil, and water. The mixer shall be one of the following, or approved equal:

[1. Portable pug-mill.

2. Portable drum roll asphalt plant, Cedarapids 4820 (with continuous flow process).]*

* P.I.D. 06-S-17

Document No. 3885-RFL-S-01-00741-04

Issued for Construction-Revision 1 
c. Equipment for spreading bentonite on the ground, if used, shall be capable of uniformly spreading the specified amount of bentonite in one or two passes, where the second pass may be made transverse to the first pass. Equipment for spreading bentonite will be subject to Contractor's approval.

D. All equipment for spreading and mixing bentonite, and for moisture conditioning radon barrier materials mixed with bentonite, will be subject to approval by the contractor.

PART 3 - EXECUTION

\subsection{PROTECTION OF EXPOSED SURFACES}

A. During seasonal shutdowns and during other periods of prolonged exposure (more than six weeks) of excavated or filled areas, the subcontractor shill provide labor, materials and equipment, as required by the contractor, to maintain and protect exposed surfaces of uncontaminated and contaminated materials against wind erosion and excessive stormwater erosion. Prior to the application of protective erosion control measures, the exposed surfaces shall be sloped to drain and compacted with a smooth drum roller to eliminate ruts and ridges formed by construction equipment. Unless otherwise approved by the contractor, acceptable methods of erosion protection are as follows:

1. Spraying with Water containing Chemical Additives: Acceptable chemical additives are CPB-12 as manufactured by Wen-Don Corporation, 206 west 2nd South, Price, Utah, 84501 and "Soil seal Concentrate" as manufactured by Soil stabilization Products Company of Merced, California, or approved equal. Mixing and application shall be in accordance with the manufacturer's recommendations, or

2. Covering exposed surfaces with geotextile fabric such as "Supac" as manufactured by Phillips Fibers corporation of Sacramento, California, or approved equal. Handling and installation shall be as recommended by the manufacturer of the product.

B. The tailings surface shall also be graded to avoid any ponding of storm water on the surface both during shutdowns and during ongoing operations.

C. Following a seasonal shutdown or period of prolonged exposure of more than 6 weeks, the contractor will verify by

Document No. 3885-RFL-S-01-00741-04

Issued for Construction-Revision 1

Earthwork 
density tests, that the last lift placed of materials previously placed and accepted by tests have been maintained at the applicable minimum specified density. Verification by density tests will be performed at frequencies to be determined by the Contractor. [Materials failing to meet specified density requirements shall be removed or reworked to satisfy the minimum specified density requirements at no additional cost to the contractor.]*

\subsection{EARTHWORK - GENERAL}

A. Preparation:

1. Required lines, levels, contours and datum shall be identified before the start of earthwork operations.

2. The Subcontractor shall verify the existing above-ground and underground utilities, identify them, and notify the contractor immediately of his finding, if any, for appropriate action.

B. Dewatering and Drainage: Prior to commencement of earthwork operations, the subcontractor shall verify that the dewatering and drainage facilities are constructed and operational in accordance with the requirements of section 02141. Temporary drainage ditches shall be constructed and maintained to provide drainage during construction.

c. In order to avoid cross-contamination of uncontaminated material, the contaminated and uncontaminated materials shall be kept separated during earthwork operations. Stockpiles of contaminated materials shall be placed on contaminated areas and the drainage collected in the retention basin.

D. The excavated uncontaminated materials, where practicable, shall be used as fill in various areas of the sites including the construction of dikes, general fill, roadway fill, structure fill, backfill, and fill for the final grading of the sites, as required. Uncontaminated excavated material may be stockpiled for later use.

E. Earthwork shall conform to lines and grades indicated on the subcontract Drawings or as specified in this section.

* P.I.D. $06-S-17$

Document No. 3885-RFL-S-01-00741-04

Issued for Construction-Revision 1

Earthwork

5432 S/WP 51

RFI-PH-II

$02200-15$

121991 


\subsection{EXCAVATION}

\section{A. General:}

1. Excavation shall be carried out to the lines and grades indicated on the subcontract Drawings or specified herein, or, in the case of contaminated materials, as required by the Contractor's Health Physics Personnel.

2. At all times, the subcontractor shall conduct his operations in such a manner as to prevent free standing water and contamination of uncontaminated materials. The subcontractor shall, as a minimum, take the following measures to safeguard against such problems:

\section{a. Water leaving a contaminated area shall be routed into the retention basin as specified in section 02141.}

b. Exposed surfaces of contaminated and uncontaminated materials excavations shall be protected from erosion as specified in Article 3.1 above.

3. The subcontractor shall remove all uncontaminated excavated material from the excavation site and dispose of it in fills required at the sites or in the designated spoil areas or use it for other purposes, as approved.

4. Unsuitable or low density subgrade material not readily capable of in-place compaction shall be excavated as directed by the contractor and disposed of as specified in Article 3.4 .

5. Adequate working space for safety of personnel shall be provided within the limits of the excavation.

6. Except as otherwise noted, care shall be exercised to preserve the material below and beyond the lines of all excavation. Where excavation is carried below grade, the subcontractor shall at his cost backfill to the required grade or to indicated invert grade, as specified, and recompact the backfill to a minimum of 90 percent of maximum dry density as determined by ASTM D698.

7. Excavation for the convenience of the subcontractor shall conform to the limits approved by the contractor and shall be at no additional expense to the contractor.

8. Excavated material shall be placed at sufficient distance from the edge of excavations to prevent cave-ins or bank slides.

Document No. 3885-RFL-S-01-00741-04

Issued for Construction-Revision 1

Earthwork 
B. Contaminated Materials Excavation:

1. [The subcontractor shall minimize where practicable the open excavation area of contaminated materials at all times during excavation work to minimize exposure to radon gas. The subcontractor shall operate from one or two sides at one time, progressing uniformly to opposite sides for completion, unless otherwise approved by the Contractor.]* Contaminated materials shall be excavated to the depths indicated on the subcontract Drawings, or as required by the contractor based on monitoring of the excavations, and placed in the proper part of the tailings embankment at the disposal site. The contaminated material shall be excavated generally in priority of its placement in the disposal cell to minimize rehandling and stockpiling.

2. Some of the sands and slimes in the tailings stockpiles at the old and New Rifle millsite have high moisture contents and may require special handling. The subcontractor shall plan his excavation of the tailings stockpiles to maximize the mixing of the sands and the slimes e.g. by vertically excavating the face of the pile. The subcontractor shall make his own determination of special handling methods to be used subject to the approval of the contractor.

3. During the excavation operation, tests will be performed by the contractor to determine radioactive contamination of the material to be excavated.

C. Uncontaminated Materials Excavation:

1. Drainage Ditches Excavation:

a. General: Ditches shall be cut accurately to the cross sections and grades where indicated. All roots, stumps, rock, and foreign matter in the sides and bottom of ditches shall be trimmed and dressed or removed to conform to the slope, grade, and shape of sections indicated. Care shall be taken not to excavate ditches below the grades indicated. Excessive ditch excavation shall be backfilled to grade with satisfactory, thoroughly compacted material as specified in Article 3.5 at no additional cost to the Contractor. Ditches shall be maintained until final acceptance of the Work.

b. Temporary Drainage Ditches: Temporary drainage ditches shall be excavated at locations shown on

* P.I.D. 06-S-17

Document No. 3885-RFL-S-01-00741-04

Issued for Construction-Revision 1 
the subcontract Drawings or as designated by the Contractor to collect and transport storm runoff, wastewater and water-bound contaminated material to the retention basins during construction. Temporary drainage ditches will not be subjected to the requirements of Article 3.8 but will be subjected to testing as determined by the contractor.

c. Permanent Drainage Ditches:

1) Ditches shall be excavated true to line and grade. Any erosion which occurs to ditch excavation before placing erosion protection materials shall be repaired with compacted backfill as specified in Article 3.5. All such repairs shall be at subcontractor's expense and shall not be included in pay quantities, unless otherwise shown on the subcontract Drawings.

2) The top 6 inches of the subgrade shall be compacted to 90 percent of maximum dry density as determined by ASTM D698 test method. After compaction has been completed, finish grading shall be done in such a manner that the side slopes are smooth surfaces. All rocks, brush, roots, large clods, and other objects shall be removed before placement of the bedding material and the riprap material.

2. Disposal Cell Foundation: The excavation for the Disposal Cell foundation shall be carried out to the lines and grades as shown on the Subcontract Drawings or as designated by the contractor. [The excavation shall extend down to a firm surface in or on the weathered bedrock or as directed by the contractor.]* In some areas it may be necessary to excavate into the weathered bedrock to provide a smooth uniform surface to promote drainage. [The subcontractor shall protect the surface of all prepared foundations from erosion, sedimentation and frost damage. Any such damage to the prepared foundations shall be corrected as required by the contractor at no additional cost to the contractor.]*

\subsection{DISPOSAL OF EXCAVATED MATERIALS}

A. Contaminated Materials: All contaminated materials excavated from the tailings piles, retention basins, evaporation ponds, other areas of the site and vicinity properties. and demolished materials and debris resulting from all

* P.I.D. 06-S-17

Document No. 3885-RFL-S-01-00741-04

Issued for Construction-Revision 1

Earthwork

5432 S/WP51

$02200-18$

121991 
sources shall be used in the construction of the tailings embankment as specified herein. Contaminated material will be placed in the tailings embankment by priority generally as indicated on the subcontract Drawings. Radiological monitoring of contaminated materials or construction expediency may change this priority, as directed by the contractor. In the course of excavation, buried foundations and structures may also be encountered. All such materials shall be placed in the tailings embankment

B. Uncontaminated Materials:

1. Uncontaminated materials excavated from the sites, including excavations for trenches, drainage ditches and retention basins which are not classified as contaminated materials, shall be used as uncontaminated material fill for construction of various features including site grading, or stockpiled for later use as specified in this section and as required by the contractor.

2. Where used in fills, such material shall be transported directly from the excavation and placed in its final position in such fills whenever possible. If required by the Subcontractor's schedule, the material may be placed temporarily in stockpiles at approved locations at the subcontractor's expense. Material in stockpiles shall be protected from contamination of any kind that would render it unsuitable for use in filis.

3. Excess uncontaminated materials remaining at the site after completion of all required fills shall be distributed over the site in the final grading. Iarger rock particles shall be placed in the lower portions of the grading fills.

c. Garbage, refuse, debris, oil, and any waste material which is harmful to the environment shall be removed from the job site and disposed of offsite in a manner approved by the authority having jurisdiction over the offsite disposal facility.

D. All operations in the stockpile areas throughout the Work shall be in strict conformity with the requirements of this section. The subcontractor shall ensure that silty water from the stockpile areas does not enter nearby waterways. If required, to control silt in runoff water, temporary berms, detention ponds or silt fences shall be constructed by the subcontractor.

Dociument No. 3885-RFL-S-01-00741-04

Issued for Construction-Revision 1

Earthwork

RT: $T-P H-I I$

$02200-19$ 
A. General Requirements:

1. Fill materials shall be placed and compacted to the lines and grades shown on the subcontract Drawings or as required by the contractor.

2. Fill slopes shall be overbuilt by two tenths of a foot, then cut back to design grade to eliminate patching or crusting of fill areas.

3. If any portion of the materials placed as fill does not meet the specified requirements, the subcontractor shall remove such material and replace it with fill materials meeting the specifications at no additional cost to the Contractor.

4. Prior to backfilling with uncontaminated fill materials, the subgrade will be radiologically surveyed by the Contractor to confirm that EPA standards have been met. These radiological surveys may cause delays to backfill operations of up to seven working days. The subcontractor shall plan his work accordingly.

5. Constructed fills shall be maintained to meet the requirements of this specification until final completion and acceptance of the Work. This shall include all measures to prevent erosion or contamination during construction, including contamination by radioactive material. During the work and during seasonal or other extended shutdowns, all exposed surfaces shall be protected with special treatments specified in Article 3.1 above.

B. Placing Requirements:

1. Prior to placement of materials, the in-place density of the soil subgrade shall be as specified in Article 3.7 . Moisture conditioning shall be as required to obtain the specified compaction.

2. No material shall be placed on any portion of the subgrade or against or upon any structure until consent to place such fill has been obtained from the contractor.

3. Materials shall not be placed on frozen subgrade or frozen embankment material foundations, nor shall frozen material be used as fill. See Article 1.4 for the definition of Frozen Material or Subgrade or Foundation.

Document No. 3885-RFL-S-01-00741-04

Issued for Construction-Revision 1

Earthwork

RFL-PH-II

$02200-20$ 
4. Contaminated materials excavated from existing tailings piles shall be placed in the lower layers of the tailings embankment. Contaminated materials excavated from the evaporation ponds, off-pile areas, and the vicinity property materials delivered to the processing site by others shall be placed in the upper portions of the tailings embankment.

5. Disposing of bulky materials shall be done with care to minimize the volume of voids created in the disposal mass. Bulky materials placed in the embankment shall, where possible, be uniformly distributed in the lower portions of the tailings embankment. Pieces of wood, concrete, and steel members shall be cut or broken up to be no greater than 20 feet in any dimension and no greater than 27 cubic feet in volume, and placed to avoid nesting in 2-foot-to-3-foot high piles with approximately 100 feet horizontal distance between the debris piles. In addition, there shall not be any debris placed within 20 feet of the outer edge of the embankment.

6. Contaminated organic materials shall not exceed 5 percent by volume and shall be evenly distributed throughout the tailings embankment layers to minimize differential settlement.

7. [Fill materials may require wetting or drying prior to compaction as approved by the contractor. Some tailings sands and slimes may require spreading and extended drying time prior to compaction.]*

8. Fill materials shall be placed in continuous and approximately horizontal layers for their full length and width unless otherwise specified or specifically permitted by the contractor.

9. Methods of dumping and spreading the materials shall ensure uniform distribution of the material.

10. The loose thickness of each layer of material shall not be greater than that required to achieve the specified compaction. For material containing particles having a maximum diameter of less than 10 inches, the loose lift thickness shall not exceed 12 inches. For material containing rock greater than 10 inches in diameter, the loose lift shall be kept to the minimum constructible thickness, as approved by the contractor, and the material between the larger particles shall receive adequate

* P.I.D. $06-S-17$

Document No. 3885-RFL-S-01-00741-04

Issued for Construction-Revision 1 
compaction as approved by the Contractor. Loose thickness of each layer of material placed in dewatered excavations below the normal groundwater level at the processing sites shall. not exceed 24 inches, and shall not be less than the maximum particle size in the backfill.

11. Unless otherwise indicated, fill materials shall be placed to a grade no flatter than 2 percent to facilitate drainage of water. In areas where ponding cannot be prevented or ponding has occurred and fill is required to be placed, placing shall begin only after the area is dewatered and permission to place is obtained from the contractor.

12. When no longer needed for control of contamination, as determined by the contractor, the temporary drainage ditches, retention basins, recirculation ponds, sumps, and the like shall be removed and the area restored and finish graded as shown on the subcontract Drawings.

c. Mixing and Placing of Radon Barrier:

1. The first lift of radon barrier shall be spread over the final contaminated material surface with a loose lift thickness sufficient to ensure that the surface of the underlying contaminated materials is not disturbed or mixed into the radon barrier.

2. The top 12 inches of the radon barrier shall consist of uncontaminated soil thoroughly mixed with bentonite.

3. The mixer for mixing bentonite with the uncontaminated material shall be capable of thoroughly mixing and controlling the percentage, by weight, of bentonite, soil and water. The mixer shall be one of the following, or approved equal:

a. Pug-mill.

b. Drum roll asphalt plant.

The bentonite-soil mixture shall be loaded into a bituminous-type paving spreader and laid down in controlled lifts as specified in this section.]*

* P.I.D. 06-S-17

Document No. 3885-RFL-S-01-00741-04

Issued for Construction-Revision 1

RFI-PH - I I

Earthwork

$02200-22$ 
4. Mixing of bentonite and soil shall be under dry conditions, not in windy/rainy conditions. Water shall be added only after dry (optimum and below) mixing of bentonite and soil are complete. The bentonite content after mixing shall not be less than 10 percent by weight. The percentage shall be determined by dividing the dry weight of bentonite by the dry weight of uncontaminated soil. Material with an initial moisture content above optimum as determined by ASTM D698 shall require spreading to accelerate drying before bentonite is added. The moisture content shall be brought to within specified limits after bentonite mixing is complete and at the time of compaction. Water shall be applied to the lift surface by methods approved by the contractor.

5. Inclement Weather: If the work of placement of radon barrier material and/or [Text Deleted]* mixing of bentonite is interrupted by heavy rain or other unfavorable weather, such work shall not be resumed until after approval of the contractor, who will determine either by visual means or by additional testing that the moisture content and density of the previously placed soil are acceptable.

6. The rados barrier layer shall be compacted to the requirements of Article 3.8 .

7. [The surface of each compacted lift of the radon barrier shall be scarified by motor grader or other approved equipment to a depth of 1 to 2 inches and moisture conditioned if necessary to bring the material within the specified range of moisture content before placement of each successive lift.]* In addition, each successive loose lift shall be harrowed prior to mixing with bentonite and water for the amended layer or to compaction for the unamended portion to ensure that there are no clod sizes in [excess of 1 inch in maximum size prior to compaction.]*

8. The final surface of the radon barrier shall be compacted in a manner to prevent formation of ruts, depressions or low areas in which water can accumulate.

9. The top surface of radon and frost barrier materials shall be maintained to the specified densities and moisture contents to a minimum depth of 2 inches until

* P.I.D. 06-S-17

Document No. 3885-RFL-S-01-00741-04

Issued for Construction-Revision 1

Earthwork

RFL-PH-II

$02200-23$

543 WP51

$\therefore 1991$ 
the drain layer material is placed. If the top surface is at densities and moisture content lower than specified, then the surface shall be scarified to a minimum depth of 2 inches compacted and moisture conditioned to bring the material within the specified range of density and moisture content.

\section{Compaction Requirements:}

1. Each lift of fill materials shall be compacted to a minimum density specified in Article 3.8 .

[2. Moisture Addition to Contaminated Materials:

a. Moisture shall only be added to contaminated materials for environmental dust control requirements. Dust control moisture shall be added to contaminated fill materials at the place of excavation preceding placement of the materials in the tailings embankment. Moisture shall not be added to contaminated materials in the tailings embankment area except when it is determined to be absolutely necessary for environmental dust control. The subcontractor shall perform his operations to minimize the need for moisture addition to the extent practicable. Moisture addition shall not be permitted for the convenience of the subcontractor. The subcontractor shall use special measures such as fine spray nozzles to add moisture to contaminated materials, as approved by the contractor, to minimize the amount of moisture added for dust control. Water from the wastewater retention basins may only be used for dust control in contaminated excavation areas, on contaminated haul roads and on contaminated fills.

b. Moisture added to radon barrier materials in the tailings embankment area shall be applied in a manner that prevents runoff onto contaminated materials.]*

[3.]* Subject to the approval of the contractor, the subcontractor shall make his own determination of the need for and extent of drying or moisture conditioning necessary in order to achieve specified placement and compaction requirements for the frost barrier and contaminated fill materials.

* P.I.D. 06-S-17

Document No. 3885-RFL-S-01-00741-04

Issued for Construction-Revision 1

Earthwork

RFI-DH-II

$02200-24$ 
[4.]* During compaction of radon barrier materials, moisture content shall be maintained within optimum to plus three (3.08) percent of the optimum as determined by ASTM D698.

[5.]* If the rolled surface of any lift of the fill in place is too wet for proper compaction of the layer of fill material to be placed thereon, it shall be removed, allowed to dry or worked with harrow, scarifier, or other suitable equipment to reduce the water content to the required amount, [and then re-compacted before the next succeeding layer of fill is placed at no additional cost to the contractor.]*

[6.]* Fill placed at densities lower than the specified minimum density or at moisture contents outside the specified acceptable range of moisture content shall be reworked to meet the density and moisture requirements or removed [and replaced by acceptable fill compacted to meet these requirements at no additional cost to the contractor.]*

[7.]* Uncontaminated fill material to be stockpiled shall be placed by spreading with a bulldozer and track walking. Compaction shall be accomplished by routing of hauling and spreading equipment units over the fill. Locations of spoil areas shall be determined by the contractor.

[8.]* Compaction of fill with more than 30 percent retained on a 3/4-inch standard sieve:

a. Prior to compaction, materials shall be moisture conditioned as approved by the contractor.

b. Compaction shall be accomplished by any of the following combinations of passes and equipment, or approved equal combination:

1) Three passes of a Caterpillar Compactor Model $825 \mathrm{C}$.

2) Three passes of a BOMAG Vibratory Roller Model 213D.

3) Three passes of a Raygo Vibratory Roller Model $400 A$.

4) Four passes of a track-type tractor with ground pressure of 9.8 pounds per square inch or greater.

* P.I.D. 06-S-17

Document No. 3885-RFL-S-01-00741-04

Issued for Construction-Revision 1

Earthwork 
[9.]* Compaction of radon barrier materials shall be accomplished by the use of tamping-foot rollers. The length of the feet on the tamping foot rollers shall not be less than 7 inches. The top surface of the contaminated materials and drainage materials shall be compacted by the use of a smooth drum roller. The weight of the smooth drum roller shall be not less than 70,000 lbs. The final lift of the radon barrier shall be bladed and compacted with a smooth drum roller after being compacted with the tamping foot roller and while the moisture content is still above optimum.

[10.]* The top surface of the compacted final lift of radon barrier shall be bladed to a uniform and smooth grade, as indicated on the subcontract Drawings, by track-walking with a D6 or larger bulldozer operating parallel to the slope.

\subsection{FIELD QUALITY CONTROL}

A. General: The Contractor will take samples and perform tests throughout the construction period, and the subcontractor shall cooperate in providing access for the contractor to areas where testing is to be performed and shall schedule his placing to avoid interference with the testing operations.

B. Tests: The contractor will perform the following tests on a regular basis.

1. In-place density and moisture content tests for compacted materials where density is specified will be as follows:

a. A minimum of one test per 1,000 cubic yards of compactable contaminated and uncontaminated materials placed at the disposal site.

b. A minimum of one test per 5,000 cubic yards of materials placed at the processing sites.

c. A minimum of one test per 500 cubic yards of radon barrier material placed.

d. At least two tests for each day of material placement in excess of 150 cubic yards.

e. A minimum of one test per lift and one test per full shift of compaction operations.

* P.I.D. 06-S-17

Document No. 3885-RFL-S-01-00741-04

Issued for Construction-Revision 1

Earthwork 
2. In-place density tests on areas of soil subgrade at a minimum of one test per 5,000 square yards of the surface area after compaction as stated in Paragraph 3.7.B.

3. [Percentage by weight passing the No. 200 sieve and 1 -inch sieve (as determined by ASTM C136, D422 and D1140) of radon barrier materials shall be a minimum of one test per 1000 cubic yards placed, with a minimum of one test per day during placement. Allow at least 24 hours for each gradation test performed by the contractor. Percentage by weight passing the No. 200 sieve and 1-inch sieve (as determined by ASTM C136, D422 and D1140) and permeability tests on samples of radon barrier material mixed with bentonite shall be a minimum of one test for every 10,000 cubic yards of materials selected to be used for radon barrier consisting of uncontaminated soil mixed with bentonite.]*

4. Gradation tests (as determined by ASTM C136), at least one test per day and a minimum of one test per 10,000 cubic yards of coarse uncontaminated material placed in dewatered excavaitions below the average seasonal high groundwater at the processing sites.

c. The placing and compacting of stockpile fills shall be subject to the approval of the contractor.

\subsection{SUBGRADE PREPARATION}

A. Subgrade Preparation: Subgrade preparation includes fine grading and compaction of excavations, backfills, embankments (including stockpiles) upon which pavement, surfacing, base, subbase, and riprap or other structures are constructed.

B. The entire surface of the subgrade exclusive of that within the colorado state Highway right-of-way and the upland drainage area north of the tailings embankment shall be compacted to 90 percent of maximum dry density as determined by ASTM D698 test method to a depth of 12 inches.

c. The surface of the subgrade of the upland drairage area north of the tailings embankment shall be compacted to 95 percent of maximum dry density as determined by ASTN D698 test method to a depth of 12 inches.

D. If subgrade is encountered which is too rocky and cannot be tested by AASHTO T99, the subgrade shall be compacted in accordance with [Article 3.5.D.8]*.

* P.I.D. 06-S-17 
E. [Where the subgrade consists of natural undisturbed bedrock, no compaction will be required.]*

[F. Where the subgrade consists of bedrock composed of fragmented or loose material, compaction shall be in accordance with Article 3.5.D.8.]*

\subsection{COMPACTION DENSITIES}

A. Each layer of embankment and backfill except for areas below the water table at the Rifle processing sites shall be compacted to at least the following percentage of maximum dry density, as determined by ASTM D698 test method:

1. Tailings Embankment: Top 2 feet beneath radon barrier

95 percent

2. Embankment and other Fill Areas including Trenches for Leachate Drain System:

90 percent

3. Trench Backfill:

95 percent

4. Radon Barrier: Top 12 inches

100 percent

5. Radon Barrier: Below top 12 inches

95 percent

6. Site Restoration:

90 percent

7. Frost Barrier:

90 percent

B. Compaction of subgrade, embankments and backfilis within the Colorado state Highway right-of-way shall comply with section 203.11 of the Colorado Standard specifications.

C. Backfill in dewatered excavations extending below the water table at the processing sites and other backfill and fill materials containing more than 30 percent by weight of the material greater than $3 / 4$ inches, shall be compacted in accordance with [Article 3.5.D.8]*.

D. Compaction densities and moisture contents shall be rounded to the nearest tenth of a percent.

* P.I.D. 06-S-17

Document No. 3885-RFL-S-01-00741-04

Issued for Construction-Revision 1 
3.9 DISPOSAL OF DEMOLISHED MATERIALS AND DEBRIS

A. All demolished materials and debris stockpiled onsite and demolished materials and debris resulting from demolition work specified in section 02050 shall be disposed of in the tailings embankment conforming to the applicable provisions of this section and as required by the contractor.

B. During construction of the tailings embankment, demolished materials and debris shall be placed concurrently with tailings.

\subsection{DISPOSAL OF VICINITY PROPERTY MATERIALS}

A. During the progress of the Work of this subcontract, contaminated vicinity properties materials shall be delivered to the New Rifle site by others under a separate subcontract from the contractor. The subcontractor shall coordinate the deliveries of such materials to conform to his construction schedule through the site Manager.

B. The subcontractor shall receive, sort and stockpile such materials, transport and spread on the tailings embankment, moisture condition, place and compact, as required, in the construction of the tailings embankment conforming to the applicable provisions of this section and as required by the contractor.

3.11 HANDLING AND DISPOSAL OF ASBESTOS, HAZARDOUS AND NONHAZARDOUS MATERIALS

A. Existing stockpiles and containers of radiologically contaminated asbestos, hazardous and non-hazardous materials shall be transported from the processing sites to the disposal site and disposed of in the construction of the tailings embankment.

B. The subcontractor shall comply with the applicable provisions of (1) Article SC-8 of the special conditions and (2) Section 02081 . 
PART 4 - MEASUREMENT AND PAYMENT

\section{1 MEASUREMENT}

A. [Measurement for payment for the following items of excavations will be by the cubic yards of material placed in the disposal cell. The quantities for payment will be computed by average end area method from surveys conducted before and after placement operations.

1. Placement into the Tailings Embankment at Estes Gulch Disposal site of all Excavated Contaminated Materials, Windblown Contaminated Materials and Contaminated Vicinity property Materials from old Rifle and New Rifle Sites and Existing Stockpiles of Demolished Materials and Debris (Bid Schedule Item 401)]*

B. Measurement for payment for the following items of excavation will be by the cubic yards of materials excavated. The quantities for payment will be computed by average end area method from surveys conducted before and after excavation operations:

1. Common Excavation of Uncontaminated Material from Temporary Drainage Ditch at Estes Gulch Disposal Site (Bid Schedule Item 216)

2. Common Excavation of Uncontaminated Material from Wastewater Retention Basin at Estes Gulch Disposal site (Bid Schedule Item 218)

3. Common Excavation of Uncontaminated Soil from Permanent Ditches at Estes Gulch Disposal Site (Bid Schedule Item 220)

4. Common Excavation of Uncontaminated Soil from Foundation of Tailings Embankment at Estes Gulch Disposal Site (Bid Schedule Item 501)

5. Common Excavation of Uncontaminated Soil for Finish Grading of Estes Gulch Disposal Site (Bid Schedule Item 801)

c. Measurement for payment for the following items of fills will be by the cubic yards of materials placed. The quantities for payment will be computed by average end area method from surveys conducted before and after placement:

* P.I.D. $06-S-17$ 
1. Placement of Excavated Uncontaminated Material from Temporary Drainage Ditch as Fill for Temporary Drainage Ditch (Bid Schedule Item 217)

2. Placement of Excavated Uncontaminated Material from Wastewater Retention Basin as Fill for Wastewater Retention Basin (Bid Schedule Item 219)

3. Placement of Excavated Uncontaminated Material from Toe Ditch as Fill for Toe Ditch (Bid Schedule Item 221)

4. Placement of Excavated Uncontaminated Materials as Fill or Backfill for Finish Grading of Estes Gulch Disposal Site (Bid Schedule Item 802)

5. Placement of Excavated Uncontaminated Materials as Fill for Radon Barrier (Bid Schedule Item 502)

6. Placement of Excavated Uncontaminated Materials as Fill for Frost Barrier (Bid Schedule Item 504)

7. Placement of Excavated Uncontaminated Materials as Fill or Backfill for Finish Grading of Old Rifle Processing Site (Bid Schedule Item 803)

D. Measurement for payment for furnishing and mixing bentonite will be by the tons of material furnished and placed. The quantities for payment will be calculated from the weigh slips of the material delivered to the site and utilized in the Work. (Bid Schedule Item 503)

E. Measurement for payment for furnishing and placing the following items of uncontaminated materials will be by the cubic yards of materials furnished and placed. The materials shall be furnished from subcontractor's own sources. The quantities for payment will be computed by average end area method from surveys conducted before and after placement:

1. Furnish and Place Coarse Uncontaminated Materials as Fill or Backfill for Finish Grading of old and New Rifle Processing Sites (Bid Schedule Item 804)

2. Furnish and Place Uncontaminated Materials (General Fill) for Finish Grading of old and New Rifle Processing sites (Bid Schedule Item 803)

F. Separate measurement for payment will not be made for the following items, and such work will be considered incidental to the related items of work:

1. Subgrade preparation. 
2. Temporary stockpiling of excavated materials.

3. Required rehandling of materials.

4. Temporary storage of bentonite.

5. Borrow area excavation, restoration, reseeding and incidental activities.

6. Protection of exposed surfaces during shutdown.

G. Overexcavation: Overexcavation for the subcontractor's convenience or due to error or lack of control by the subcontractor will not be measured for payment. At the discretion of the Contractor, such overexcavation shall be backfilled with compacted contaminated or uncontaminated fill, as required, at the subcontractor's expense.

H. Separate measurement for payment will not be made for any other excavations or fills specified in this section.

I. Measurement for payment for the following will be by Iump sum:

1. Handling and Removal of Existing Stockpiles of Demolished Materials and Debris and Asbestos, Hazardous and other Nonhazardous Materials from Old and New Rifle Processing Sites and Disposal at Estes Gulch Disposal Site (Bid Schedule Item 403)

J. Measurement for payment for disposal of demolished materials and debris resulting from work specified in section 02050 of this subcontract will be as specified in section 02050 .

[K. Measurement for payment for furnishing and installing displacement monuments will be by the number of monuments installed. ]*

4.2 PAYMENT

A. Payment for the items of Article 4.1.A above will be by their applicable unit prices per cubic yard quoted therefor in the Bid Schedule. The prices quoted shall include full compensation for excavating, hauling, and placing the excavated materials in their final locations including all clearing at the processing site, stripping, grading, shaping, preparing subgrade, moisture conditioning, compacting, temporary stockpiling and required rehanding.

* P.I.D. 06-S-17 
B. Payment for the items of Article 4.1.B above will be by their applicable unit prices per cubic yard quoted therefor in the Bid schedule. The prices quoted shall include full compensation for excavating, hauling, and placing the excavated materials in temporary stockpiles, or in spoil areas if excess or unsuitable for use as fill, as required, including all clearing at the processing site, stripping, grading, shaping, and compacting such stockpiles or areas as specified.

c. Payment for the items of Article 4.1.C above will be by their applicable unit prices per cubic yard quoted therefor in the Bid schedule. The prices quoted shall include full compensation for hauling the materials from excavated areas or retrieving the materials from temporary stockpiles, as required, and placing the excavated materials in their final locations including all clearing at the processing site, stripping, grading, shaping, preparing subgrade, and compacting, a.s required.

D. Payment for furnishing and mixing bentonite will be by the unit price per ton quoted therefor in the Bid schedule. The price quoted shall include full compensation for hauling and mixing bentonite with uncontaminated fill for placement as radon barrier.

E. Payment for the items of Article 4.1.E above will be by their applicable unit prices per cubic yard quoted therefor in the Bid schedule. The prices quoted shall include full compensation for furnishing the required materials from the subcontractor's own sources and placing, including clearing, stripping, grading, shaping, preparing subgrade, moisture conditioning and compacting, and restoration of borrow areas, as required.

F. Separate payment will not be made for the items mentioned in Article 4.1.F above. All costs for such work will be considered to be included in the prices quoted for the applicable related items of work.

G. Separate payment will not be made for any other excavations or fills specified in this section. All costs for excavations or for furnishing and placing such fills will be considered to be included in the related items of excavation.

H. Payment for the items of Article 4.1.I above will be by their applicable lump sum prices quoted therefor in the Bid schedule. The prices quoted shall include full compensation for loading and transporting the materials and containers from the processing sites to the disposal site, and placing and compacting in the tailings embankment. 
I. Payment for disposal of demolished materials and debris resulting from the work specified in Section 02050 of this subcontract will be as specified therein.

J. Payment for handling and disposal of (contaminated) vicinity properties materials will be by the unit price per cubic yard quoted therefor in the Bid Schedule. The price quoted shall include full compensation for coordinating the delivery of materials with the vicinity properties subcontractor, receiving and placing the materials in the tailings embankment including moisture conditioning and compacting, as required.

K. Separate payment will not be made for prolonged maintenance of stockpiles, slopes, cuts or fills, as stated in Articles 3.1.A.1, 3.1.A.2 and 3.1.B of Seasonal Shutdown.

[L. Payment for furnishing and installing displacement monuments will be by the unit price quoted therefor in the Bid Schedule.]*

END OF SECTION 02200

* P.I.D. 06-S-17 
GROUND SURFACE PREPARATION FOR DISPOSAL CELL LINER

\section{PART 1 - GENERAL}

\subsection{SCOPE}
A. This Specification section covers preparation of subgrade for liner in the disposal cell.
B. Membrane liner is specified in section 02771 .
c. Earthwork is specified in section 02200 .

\subsection{APPLICABLE PUBLICATIONS}

A. The Publications listed below form a part of this specification to the extent referenced. The Publications are referred to in the text by the basic designation only:

1. American Society for Testing and Materials (ASTM):

D422 Method for Particle-size Analysis of Soils

D698 Test Methods for Moisture-Density Relations of Soils and Soil-Aggregate Mixtures Using 5.5-1b. $(2.49-\mathrm{kg})$ Rammer and 12-in. (305-mm) Drop

D1556 Test Method for Density of Soil in Place by the Sand-Cone Method

D2216 Test Method for Laboratory Determination of Water (Moisture) Content of soil, Rock, and Soil-Aggregate Mixtures

E11 Standard Specification for Wire-cloth Sieves for Testing Purposes

\subsection{SUBMITTALS}

A. If the subcontractor proposes to import material for use as liner bedding shown on the subcontract Drawings and as specified herein, he shall submit to the contractor for approval three 50-1b. bags of the material at least 30 days prior to starting liner subgrade preparation. The bags shall be labeled with date sampled and specific location and description of the material source.

Document No. 3885-RFL-S-01-03935-01

Issued for Construction-Revision 1

Ground Surface Preparation for Disposal Cell 0091s/wp51 
B. At least 30 days before placement of liner bedding material, as specified in Article 2. 1 , the subcontractor shall submit to the contractor for approval the method for stabilizing or protecting the liner bedding material from wind and rain erosion.

PART 2 - PRODUCTS

\subsection{MATERIALS}

A. Gradation: The specified gradation of the liner bedding material is shown below:

$$
\begin{aligned}
& \text { U.S. Standard sieve size } \\
& \text { (Square openings) }
\end{aligned}
$$

$$
\begin{aligned}
& \text { 1-inch } \\
& \text { No. } 4 \\
& \text { No. } 200
\end{aligned}
$$

\author{
Percent Passing \\ (by Weight)
}

$$
\begin{gathered}
100 \\
45-85 \\
5-15
\end{gathered}
$$

B. Source Quality control: The materials shall be inspected and tested by the subcontractor at the borrow area to ensure that they meet all requirements of this specification. Gradation requirements will be tested by the contractor at the placement location.

c. To minimize the quantity of angular particles, crushing will not be permitted.

D. Material containing brush, roots, wood or other organic, perishable materials or any debris such as wire, metal objects or other deleterious materials, snow, ice or frozen soil, shall not be placed in the work. If for any reason the subcontractor places unsuitable material in the work, all such materials shall be removed, disposed of and replaced by and at the expense of the subcontractor.

E. Certification from the Installation supervisor shall be required stating that the surface on which the liner is to be placed is acceptable. No installation of lining shall commence until this certification is furnished to the contractor. The receiving surface shall be kept in the accepted condition until the installation of the lining is accomplished.

Document No. 3885-RFL-S-01-03935-01

Issued for Construction-Revision 1 
PART 3 - EXECUTION

\subsection{GENERAL REQUIREMENTS}

A. No liner bedding materials shall be placed on the subgrade until the subgrade has been accepted by the contractor.

B. Liner bedding shall not be placed upon a frozen surface.

c. If any tests performed by the contractor determine that any part of the liner bedding does not meet the specified gradation, the subcontractor shall remove such material and replace it with fill meeting the specifications at no additional cost to the contractor.

D. The subcontractor shall protect the liner bedding placed on the disposal cell against erosion. Any erosion damage such as ruts or holes in the surface of the liner bedding shall be filled and compacted as approved by the contractor at no additional cost to the contractor.

E. The final compacted surface of the liner bedding in the disposal cell shall be maintained in a smooth, uniform and compacted condition during installation of the liner. Ravelling or damage (e.g., due to foot traffic) of the surface shall be repaired as required by the contractor at no additional cost to the contractor.

\subsection{SURFACE AREA}

A. Surfaces to be lined shall be smooth and free of all rocks, stones, sticks, roots, sharp objects, and debris. No stones larger than 1/2-inch in diameter shall be permitted within 6 inches of the surface. No standing water or excessive moisture shall be allowed on the surface to be lined. organic material or protruding boulders exposed on the surface to be lined shall be removed and the void backfilled with liner bedding material and compacted with hand tampers as approved by the contractor.

B. The subgrade for the liner bedding shall be prepared by the subcontractor to the elevations and grades shown on the subcontract Drawings.

c. Prior to placing liner bedding material, the final subgrade surface shall be compacted by 2 passes of the specified roller. No vibration shall take place during downslope travel of the roller. Areas not accessible to the roller shall be compacted by approved mechanical or hand tampers.

Document No. 3885-RFL-S-01-03935-01

Issued for Construction-Revision 1

Ground Surface Preparation for Disposal Cell 0091s/WP51 
D. Liner bedding material shall be spread uniformly onto the compacted subgrade. The material shall be moisture conditioned to within plus or minus 2 percent of optimum moisture content and compacted to at least 95 percent of the maximum dry density as determined by ASTM D698. Liner bedding material shall have a compacted lift thickness of 6 inches, measured perpendicular to the subgrade.

\subsection{COMPACTION EQUIPMENT}

A. Compactors shall be smooth drum vibratory rollers. The rollers may be either towed by separate vehicle or be selfpropelled.

B. When rollers are operated in sets or tandem, or sets of rollers are operated one behind the other in the same track, all rollers operated in this manner shall be of the same dimensions, widths, weights, and operating characteristics. If vibratory rollers are hauled by a separate traction unit. it shall have sufficient power to pull the rollers satisfactorily when the rollers are ballasted to the specified weight.

c. Vibratory rollers shall have a total static weight of not less than 20,000 pounds with at least 90 percent of the weight transmitted to the ground through a single smooth steel drum when the roller is in a level position. The diameter of the drums shall be a minimum of five feet and a maximum of five feet and six inches, and the width shall be a minimum of six feet and and a maximum of six feet and six inches. The drums shall be equipped with suitable cleaning devices to keep them free of any accumulation of material. The frequency of vibration during operation shall be between 18 cps and 25 cps and the dynamic force applied by the roller shall be not less than 40,000 pounds at a frequency of operation of $23 \mathrm{cps}$.

D. Towed-rollers shall be suitable for towing at speeds not exceeding three miles per hour by a crawler tractor with a minimum drawbar rating of 50 horsepower.

E. The Subcontractor shall make all necessary adjustments during the progress of the work to ensure that the equipment obtains the required result in accordance with the specifications.

F. Special compaction equipment shall be used in restricted spaces or in any location where the specified rollers cannot operate effectively as determined by the contractor. The equipment shall be capable of producing densities equivalent to those densities produced by the

Document No. 3885-RFL-S-01-03935-01

Issued for Construction-Revision 1 
specified vibratory rollers. All such equipment will be subject to approval of the Contractor. Compactors which do not obtain the required density with a reasonable amount of coverage of each layer and at a production rate consistent with the adjacent work, shall not be used. Compacted layer thicknesses by this equipment shall be as approved by the contractor and will be determined from the maximum particle size of the material.

\subsection{INSPECTION AND TESTING}

The Contractor will perform all tests of the liner bedding material for the placement operations to verify compliance with the specifications. The contractor will conduct density and other tests on the compacted material and the related laboratory testing to determine the relative degree of compaction and other properties. The subcontractor shall cooperate in providing access for the contractor to areas where testing is to be performed and shall schedule his placing operations to avoid interference with the testing work. Tests performed by the contractor will be in accordance with the Standards, Paragraph 1.2.A. [One compaction test will be performed for every 1000 cubic yards of bedding material placed.]*

PART 4 - MEASUREMENT AND PAYMENT

\subsection{MEASUREMENT}

A. Measurement for payment for preparation of subgrade for liner bedding material will be the number of square yards prepared in accordance with the subcontract Drawings and Specifications.

B. Measurement for payment of liner bedding material will be the number of cubic yards satisfactorily placed in accordance with Subcontract Drawings and specifications.

* P.I.D. 06-S-17

Document No. 3885-RFL-S-01-03935-01

Issued for Construction-Revision 1.

Grouna Surface Preparation for Disposal Cell 0091s/Wp5I 


\subsection{PAYMENT}

A. Payment for preparation of subgrade for liner bedding material will be made at the unit price per square yard quoted in the Bid schedule and shall include all costs for removing objects that protrude above the excavation design line and compacting the subgrade as specified herein.

B. Payment for liner bedding material will be made at the unit price per cubic yard quoted in the Bid Schedule and shall include all costs for stabilizing or protecting the liner bedding material.

END OF SECTION 02216

Document No. 3885-RFL-S-01-03935-01

Issued for Construction-Revision 1

Ground Surface Preparation for Disposal Cell 0091s/WP5I 
SECTION 02230

AGGREGATE BASE

\section{PART 1 - GENERAL}

\subsection{SCOPE}

A. This specification section describes the requirements for furnishing and placing of the following:

1. Aggregate base course materials for:

a. Access control, monitoring and staging axea at Estes Gulch site.

[ Text Deleted]*

[b.]* West access road at old Rifle processing site.

2. Aggregate subbase materials for:

a. Access control, monitoring and staging area at Estes Gulch site.

[ Text Deleted]*

[b.]* West access road at old Rifle processing site.

1.2 WORK NOT INCLUDED

Temporary roads as defined in Article sC-1 of the special conditions.

1.3 RELATED WORK

A. Section 01300 - submittals

B. Section 02200 - Earthwork

$\star$ P.I.D. 06-S-17 


\subsection{APPLICABLE PUBLICATIONS}

A. The Publications listed below form a part of this specification to the extent referenced. The Publications are referred to in the text by the basic designation only:

1. American Society for Testing and Materials (ASTM):

D1557-78 Test Methods for Moisture-Density Relations of Soils and Soil-Aggregate Mixtures Using 10 lb. $(4.54-\mathrm{kg})$ Rammer and 18-in. $(457-\mathrm{mm})$ Drop

2. Standard Specifications for Road and Bridge Construction, State of Colorado, Department of Highways, Highway Division, 1981. All references to "Engineer" shall mean "Site Manager"; all references to "Division"

shall mean "Contractor"; and all references to "Contractor" shall mean "Subcontractor". The provisions for sampling of paving for measurement and payment shall not be applicable. All references to "special provisions" shall not be applicable. Measurement and payment provisions shall be as specified in this section.

\subsection{QUALITY ASSURANCE}

A. Aggregate Base and Subbase:

1. Aggregate base and subbase course materials and operations will be subject to inspection, sampling and testing by the contractor or a commercial testing laboratory. Inspection personnel shall have unrestricted access to the work.

2. Inspection personnel may analyze and test materials in the field or laboratory as directed by the contractor to determine conformance with these Specifications.

\subsection{SUBMITTALS}

The subcontractor shall submit a certificate from the manufacturer or supplier stating that the material furnished meets the specifications in all respects. 


\subsection{EQUIPMENT}

The subcontractor shall provide all equipment and facilities required to perform the work of this specification. The equipment and facilities shall be subject to approval by the contractor.

\subsection{MATERIALS}

A. Base and Subbase Materials:

1. Materials for base and subbase courses shall conform to the applicable provisions of section 703 of the colorado standard Specifications.

2. Base course materials shall be class 6 with gradation limits as follows:

$$
\begin{aligned}
& \text { U.S. Standard Sieve Size Percent Passing } \\
& \text { (square openings) } \\
& \text { (By Weight) } \\
& \text { 3/4-inch } \\
& 100 \\
& \text { No. } 4 \\
& \text { No. } 8 \\
& 30-65 \\
& \text { No. } 200 \\
& \text { 25-55 } \\
& \text { 3-12 }
\end{aligned}
$$

3. Subbase Course Materials:
a. Subbase course materials shall be Class 1 and Class 2 as indicated on the subcontract Drawings.
b. Gradation:

1) Class 1:
U.S. Standard Sieve Size (square Openings)

Percent Passing

$$
\begin{aligned}
& 2-1 / 2-\text { inch } \\
& 2-\text { inch } \\
& \text { No. } 4 \\
& \text { No. } 200
\end{aligned}
$$

(By Weight)

$$
\begin{gathered}
100 \\
95-100 \\
30-65 \\
3-15
\end{gathered}
$$



U.S. Standard Sieve Size (Square openings)

4-inch
3-inch
No. 200
Percent Passing (By Weight)

$$
\begin{gathered}
100 \\
95-100 \\
3-15
\end{gathered}
$$

\section{PART 3 - EXECUTION}

\subsection{EARTHWORK AND SUBGRADE PREPARATION}

A. Earthwork and subgrade preparation shall be as specified in Section 02200, except that test frequencies shall be as determined by the contractor.

B. Before placing and spreading subbase and base course material the subgrade shall be cleaned of all foreign substances and shall contain no frozen material. It will be inspected by the contractor for adequate compaction and surface tolerances.

\subsection{CONSTRUCTION OF SUBBASE AND BASE COURSES}

A. The construction of the subbase and base courses shall follow the requirements of Colorado Highway Division Specifications Section 304 except as modified herein and as approved by the Contractor.

B. Placement: Both the subbase and base course shall have water added and each course shall be separately mixed and processed so as to produce a uniform blend of material before final placement. After processing, each course shall be separately placed and spread on the prepared subgrade, in a uniform layer or layers not exceeding 6 inches in compacted depth, unless otherwise approved in writing by the contractor. The spread material shall be free from segregation.

C. Compaction: Each layer of aggregate subbase and base courses shall be compacted to a density of not less than 95 percent of the maximum dry density determined in accordance with the requirements of ASTM D1557.

D. Finishing:

1. The final layer of base course shall be finished with equipment capable of shaping and gracing the finish surface within the tolerances specified herein. 
2. The finished surface of aggregate subbase and base courses shall not vary from the grades established by the Contractor by more than 0.08 of a foot.

3. The compacted layer of aggregate base course shall be maintained in a condition satisfactory to receive the pavement material when so required.

4. Areas not within the allowable tolerance shall be corrected by scarifying, placing additional material, remixing, reshaping and recompacting to the specified density and surface tolerance [at no additional cost to the Contractor]*.

\subsection{MAINTENANCE}

The prepared surfaces shall be maintained by the subcontractor in good condition, free of pot holes, ruts and ravels.

\section{PART 4 - MEASUREMENT AND PAYMENT}

\subsection{MEASUREMENT}

A. Measurement for payment for furnishing and placing following materials will be by the cubic yards of the materials furnished and placed. The quantities for payment will be calculated from the lines and dimensions shown on the subcontract Drawings and accepted by the site Manager:

1. Aggregate base course materials for access control, monitoring and staging area at Estes Gulch disposal site.

[Text Deleted]*

[2.]* Aggregate base course materials for west access road at ola Rifle processing site.

[3.]* Aggregate subbase course materials for access control, monitoring and staging area at Estes Gulch disposal site.

[Text Deleted]*

[4.]* Aggregate subbase course materials for west access road at old Rifle processing site.

* P.I.D. 06-S-17 
B. Measurement for payment for earthwork and subgrade preparation is specified in section 02200.

\subsection{PAYMENT}

A. Payment for furnishing and placing the materials of Article 4.1. A abcve will be by their applicable unit prices per cubic yard quoted therefor in the Bid schedule.

B. The prices quoted shall include full compensation for furnishing all labor, materials, tools, equipment, and incidentals, for doing all work involved in constructing aggregate subbases and bases, complete in place, and for protection and maintenance of completed work, as shown on the Subcontract Drawings, as specified in these specifications and as required by the contractor.

c. Payment for earthwork and subgrade preparation is specified in section 02200 .

END OF SECTION 02230 


\section{SECTION 02278}

\section{EROSION PROTECTION}

\section{PART 1 - GENERAL}

1.1 SCOPE

This specification section describes the requirements for furnishing and placing erosion protection materials (riprap and drainage) for tailings embankment cover and aprons and for the permanent drainage ditches at the disposal site.

1.2 WORK NOT INCLUDED

Erosion protection related to the construction Facilities and Temporary Controls specified in sections 01500 and 01560 is not included in the scope of work of this specification.

1.3 RELATED WORK

A. Section 01300 - Submittals

B. Section 02200 - Earthwork: Subgrade Preparation

1.4 APPLICABLE PUBLICATIONS

A. The publications listed below form a part of this specification to the extent referenced. The publications are referred to in the text by the basic designation only:

1. American society for Testing and Materials (ASTM):

c88-83 Test Method for Soundness of Aggregates by Use of Sodium Sulfate or Magnesium Sulfate

c117-87 Test Method for Materials Finer Than 75 Microns (No. 200) Sieve in Mineral Aggregates by Washing

c127-84 Test Method for Specific Gravity and $\mathrm{Ab}-$ sorption of Coarse Aggregate

C131-89 Test Method for Resistance to Degradation of Small-size Coarse Aggregate by Abrasion and Impact in the Los Angeles Machine.

c136-84 Test Method for Sieve Analysis of Fine and Coarse Aggregates

Document No. 3885-RFL-S-01-00743-04

Issued for Construction-Revision 1 Erosion Protection 

C295-85
Practice for Petrographic Examination of Aggregates for concrete.
D75-87
Standard Practice for Sampling Aggregates.

2. International Society for Rock Mechanics (ISRM), 1981, Rock Characterization Testing and Monitoring, ISRM Suggested Methods, E. T. Brown, Editor, Pergamon Press, New York:

Suggested Method for Determining Indirect Tensile strength by the Brazil Test, pp. 120-121

Suggested Method for Determination of the schmidt Rebound Hardness, pp. 101-102

\subsection{PERMITS}

Conform to Article SC-11.B of section 00800 .

\subsection{SUBMITTALS}

A. The technical submittal covering the production of erosion protection materials shall include, but not be limited to, the following:

1. Narrative acknowledging permit stipulations for each rock borrow source.

2. Mining plan.

3. Use, handling and storage of explosives.

4. Expected quarry breakage or pit analysis.

5. Required combined product gradation.

6. Production analysis.

7. Flow diagram of production plant showing all products and wasteage in tons per hour.

8. Plant layout showing individual pieces of equipment.

9. Complete list of equipment with manufacturers' models, capacities, horsepower and expected production curves.

10. Schedule.

11. Manpower required.

Document No. 3885-RFL-S-01-00743-04

Issued for construction-Revision $I$ Erosion Protection 
12. Handing of finished products.

13. Safety.

14. Maintenance of public and on site haul roads.

15. Dust control.

16. Protection of archaeological sites.

17. Quality control.

B. If the subcontractor determines to use other sources for erosion protection materials, a site inspection report containing the information specified in Article 2.3 below shall be submitted, in triplicate, to the contractor for review and approval of the source, in accordance with the requirements of section 01300 .

C. [During production of riprap and drainage materials, the subcontractor shall submit gradation test results, in triplicate, to verify that gradations are in accordance with the specifications. For riprap materials, drainage materials, drain rock, sand blanket and bedding materials, gradation tests for each type material shall be performed a minimum of four times during production.]* An initial sample shall be obtained and tested during the early stages of production activities. Additional samples shall be obtained and tested when approximately one-third and two-thirds of the total volume of material has been produced, and a final sample shall be obtained and tested near completion of production activities. [If the total individual volume of material for riprap, drainage materials, drain rock, sand blanket and bedding materials is greater than 30,000 cubic yards, a gradation test shall be performed for each additional 10,000 cubic yards, or fraction thereof tested in accordance with ASTM D75.]* The frequency for performing the gradation tests shall be when approximately 100 cubic yards of material has been produced and near completion of production activities.

\section{PART 2 - PRODUCTS}

\subsection{GENERAL}

A. [Material sources: Erosion protection materials shall be obtained from sources approved by the contractor. The

* P.I.D. 06-S-17

Document No. 3885-RFL-S-01-00743-04

Issued for Construction-Revision 1

Erosion Protection 
approved source for Types $A$ and B riprap, and Types D1 and D2 drainage materials are the Frei Pit at silt, the casey Concrete Pit at Rifle and Roaring Fork Resources Inc. UMETCO Pit at Rifle. The basis for approval of other sources is specified in Article 2.3 below. J*

B. Approval of a source as a borrow area does not mean that all materials excavated will meet the requirements of this Specification. Processing or selective quarrying may be necessary to meet these requirements.

C. The materials shall be free from radioactive or other contamination.

D. Material shall be dense, sound, resistant to abrasion, and shall be free from cracks, seams, and other defects as shown in the petrographic examination and during field inspection as per Article 3.3.B.1 below.

E. Quality and Gradation Tests: For record purposes the following tests will be performed by the contractor:

Test

Gradation

Specific Gravity (Saturated Surface Dry Basis)

Absorption

soundness

Abrasion

Schmidt Hammer

Splitting Tensile strength (Modified-Loading Rate Shall

Cause Failure in 1 to 3 minutes)

Petrographic Examination
Designation

ASTM $\quad 117$

ASTM C136

ASTM $\mathrm{C} 127$

ASTM $\quad C 127$

ASTM C88 (5 cycles)

ASTM C131

(100 revolutions)

ISRM Method

ISRM Method

ASTM C295

\subsection{QUALITY REQUIREMENTS}

A. [A]l riprap, drainage materials, drain rock, sand blanket and bedding materials used shall meet the following requirements as tested by the contractor: ]*

* P.I.D. 06-S-17

Document No. 3885-RFL-S-01-00743-04

Issued for construction-Revision 1

Erosion Protection 
1. [The tests specified in Table $A$ shall be taken at the same frequency specified in Article 1.6.C for gradations for each material type.]* The score for each test is determined by multiplying the appropriate weighing factor by the score ( 0 to 10 ) based on the specific test result. The final score for each sample is the ratio of the sum of the individual test scores (six tests) to the maximum possible score, expressed as a percentage. [To be acceptable, the final score shall be no less than 80 percent for riprap and 65 percent for drainage materials, sand blanket, rock drain and liner bedding.]*

2. [The Splitting Tensile strength Test, and Petrographic Examination will not be required on the riprap materials, drainage materials, sand blanket, rock drains and liner bedding at the frequency specified in Article 1.6.C. The Schmidt Hammer Test will not be required at the frequency specified in Article 1.6.C on the drainage materials, sand blanket and liner bedding. When scoring the materials mentioned above, the splitting Tensile strength Test and the Schmidt Hammer Test shall not be used as a criteria for scoring. An additional Petrographic Examination shall be taken in the event that unforeseen material types are encountered during the production operation. For the sand blanket and drain rock, petrographic examinations to verify that not more than 5 percent of the material is composed of limestone and/or dolomite, in accordance with section 02144 , shall be conducted at the frequencies specified in Article $1.6 . \mathrm{C}]$.

3. If a combination of limestone, sandstone and igneous rock is found for a source, the source will be analyzed by the Contractor and percentages of each type of material will be given to the subcontractor for calculating a score.

\subsection{SUBCONTRACTOR-PROPOSED SOURCES}

A. The basis for approval of sources proposed by the subcontractor shall be as follows:

1. A site inspection report by an independent testing laboratory's engineering geologist which will include, as a minimum, an evaluation of soundness, hardness, and durability for three samples representative of the proposed source. The evaluation of durability shall be based in part on petrographic examination of rock types available from the source. In addition, the material shall meet the quality requirements of

* P.I.D. 06-S-17

Document No. 3885-RFL-S-01-00743-04

Issued for Construction-Revision 1

Erosion Protection 
Article 2.2. A above. The site inspection report shall be submitted 30 days prior to anticipated production of the material. The subcontractor shall also provide access to the source for the contractor for the purpose of investigating and sampling the source materials at least 90 days prior to production of the erosion protection materials. Representativeness of samples shall be determined by the contractor, based on precise location and source of sample taken in relation to the whole borrow area. The site inspection report shall include locations of all samples and methods of sampling.

2. The subcontractor shall have a qualified laboratory perform the six (6) types of tests listed in Table A on each sample (minimum of 3 samples) obtained from each proposed source. A Contractor's representative will be in attendance during the testing. Special attention shall be given to ensure that the samples are representative of the proposed rock materials. Test samples shall be obtained from within the precise locations of rock deposits from which materials will be produced. To be approved as a source, the final score for each sample shall be obtained and evaluated as specified in Paragraph 2.2 A.1.

\subsection{GRADATION REQUIREMENTS}

A. Materials shall be reasonably well graded within the following limits:

1. Riprap:

a. Gradation: Riprap materials shall be reasonably well graded within the following limits. The sizes are specified in terms of square openings of U.S. standard sieves or by the Nominal sizes of the Materials.

U.S. Standard

Sieve Size/Nominal size (square openings)

Percent Passing (by weight)

$$
\begin{aligned}
& \text { Type A } \\
& \text { 6-inch } \\
& \text { 5-inch } \\
& \text { 4-inch } \\
& \text { 2-inch } \\
& \text { 1-1/4-inch }
\end{aligned}
$$

$$
\begin{aligned}
& 100 \\
& 50-100 \\
& 35-75 \\
& 0-20 \\
& 0-5
\end{aligned}
$$

Document No. 3885-RFL-S-01-00743-04

Issued for Construction-Revision 1 


\begin{tabular}{|c|c|}
\hline Type B & \\
\hline $\begin{array}{l}\text { 10-inch } \\
\text { 8-inch } \\
6 \text {-inch } \\
4-\text { inch } \\
\text { 2-1/2-inch }\end{array}$ & $\begin{array}{l}100 \\
50-100 \\
30-60 \\
0-25 \\
0-5\end{array}$ \\
\hline $\begin{array}{l}\text { [Type C } \\
42-\text { inch } \\
18 \text {-inch } \\
12-\text { inch } \\
8 \text {-inch }\end{array}$ & $\begin{array}{c}100 \\
40-100 \\
18-30 \\
0-10\end{array}$ \\
\hline $\begin{array}{l}\text { Type D } \\
42 \text {-inch } \\
36 \text {-inch } \\
24 \text {-inch } \\
18 \text {-inch } \\
12 \text {-inch } \\
8 \text {-inch }\end{array}$ & $\begin{array}{l}100 \\
90-100 \\
25-50 \\
15-30 \\
3-12 \\
0]^{\star}\end{array}$ \\
\hline
\end{tabular}

b. Maximum Size: No individual piece shall be greater than 90 percent of the riprap layer thickness.

2. Drainage Materials:

a. Drainage materials shall be obtained from borrow areas approved by the contractor. The subcontractor shall process the materials, as required, to meet the gradation requirements specified below.

b. Gradation: Drainage materials shall be reasonably well graded within the following limits:

U.S. Standard sieve size (Square Openings)

Percent Passing (by weight)

100
$85-100$
$70-100$
$50-73$
$40-57$
$28-44$
$8-22$
$0-5$
less than 3

* P.I.D. 06-S-17 


\begin{tabular}{lr} 
Type D2 & \\
\hline $3 / 4-$ inch & 100 \\
$3 / 8-$ inch & $85-100$ \\
No. 4 & $67-90$ \\
No. 10 & $44-67$ \\
No. 30 & $17-37$ \\
No. 60 & $5-21$ \\
No. 100 & $0-13$ \\
No. 200 & less than 3
\end{tabular}

B. Source Quality control: The materials shall be inspected and tested by the subcontractor at the borrow area to ensure that they meet all requirements of this specification. Gradation requirements will be tested by the contractor at the placement location.

\section{PART 3 - EXECUTION}

\subsection{PLACEMENT AND COMPACTION}

[A. General: Erosion protection materials shall be handled, loaded, transported, stockpiled, and placed in a manner which avoids nonconformance with specifications due to segregation and degradation, including materials moved to and from stockpiles.]*

[B.]* Subgrade preparation shall be as specified in specifications section 02200.

[C.]* Where the required drainage material thickness is 6 inches or less, the drainage material shall be spread and compacted in one layer. Where the required thickness is more than 6 inches, the material shall be spread and compacted in two or more layers of approximately equal thickness and the maximum compacted thickness of any one layer shall not exceed 6 inches.

[D.]* Each layer of drainage material shall be track walked with two passes of a D6 bulldozer or equivalent operating up and down the slope over the entire area of placement.

[E.]* Placing of material by methods which will tend to segregate particle sizes within the drainage will not be permitted.

[F.]* Test section: For placement control purposes one test section each shall be constructed for the Type $A$ and the Type

* P.I.D. 06-S-17

Document No. 3885-RFL-S-01-00743-04

Issued for Construction-Revision 1

Erosion Protection 
B riprap installations. The equipment and procedures used shall be similar to those used on the embankment. The test sections shall be not less than $30^{\prime}$ wide by $50^{\prime}$ long in size. The finished test sections, after testing to ensure that the in-place gradation requirements have been met, shall be used as a visual sample for comparison of production work. After completion of riprap installation, the test sections may at the subcontractor's option be incorporated into the embankment or may be removed and the ground blended into the final grading contours, as approved by the contractor.

[G.]* Riprap material, up to a maximum nominal size of 10 inches, may be placed by end-dumping and may be spread by bull-dozers or other suitable equipment.

[H. Riprap materials shall be placed in a manner which avoids displacing underlying materials beyond thickness specifications for the underlying materials.]*

[I.]* Dumped riprap shall be placed to its full course thickness in one operation and in such a manner as to avoid displacing the drainage material. The larger stones shall be well distributed throughout the mass. The finished riprap shall be free from pockets of small stones and clusters of larger stones. Placing stone in layers will not be permitted. Placing stone by dumping into chutes or by similar methods likely to cause segregation of the various sizes will not be permitted. The desired distribution of the various sizes of stones throughout the mass shall be obtained by selective loading of the material at the quarry or other source, by controlled dumping of successive loads during final placing, or by other methods of placement which will produce the specified results. Rearranging of individual stones by mechanical equipment or by hand will be required to the extent necessary to obtain a reasonably well graded distribution of stone sizes as specified above.

[J.]* For riprap placed by clam-shell or similar equipment, hand arrangement will be required only to the extent necessary to secure the results specified herein. stones shall be selected individually and positioned manually under experienced supervision so as to produce an essentially solid face of rock with joints closely perpendicular to the face and with all stones firmly wedged in place. Any stones which are not firmly wedged, in the opinion of the contractor, shall be adjusted by crow-bars or similar tools and additional selected stones inserted, or existing stones replaced, so as to achieve solid interlock.

* P.I.D. 06-S-17

Document No. 3885-RFL-S-01-00743-04

Issued for Construction-Revision 1

Erosion Protection 
[K.]* Each layer of riprap shall be track-walked by two passes of a D6 bulldozer or equivalent.

[L.]* Construction equipment other than spreading and compaction equipment shall not be allowed to move over the placed riprap material and drainage material layers except at equipment crossovers as designated by the contractor. Fill materials shall be placed temporarily at equipment crossovers to prevent degradation of placed riprap materials. Each crossover shall be cleaned of all contaminating materials and approved by the contractor before additional materials are placed in these areas.

\subsection{TOLERANCES}

A. The material layers shall be placed generally to the limits and thicknesses shown on the subcontract Drawings within the following tolerances. Sufficient stakes shall be set in each section so that stringlines or other means can be used to verify the in-place thickness.

1. The top of all layers with the exception of the radon barrier shall be within \pm 0.1 foot of the design elevations shown on the subcontract Drawings. The thickness of the radon barrier shall be within \pm 0.1 foot of the design thickness shown on the subcontract Drawings.

2. The minimum in-place thickness for riprap shall not be less than 90 percent of the thickness shown.

3. The maximum in-place thickness for riprap shall not be more than 125 percent of the thickness shown.

4. Local irregularities not exceeding the limits of Paragraphs 2 and 3 above will be permitted provided that such irregularities do not form noticeable mounds, ridges, swales or depressions which in the opinion of the contractor could cause concentrations of surface runoff or form ponds or gullies.

\subsection{FIELD QUALITY CONTROL}

A. Source Quality control: The subcontractor shall provide a qualified engineering geologist to monitor materials acquisition and production to ensure that only materials

* P.I.D. $06-S-17$ 
acceptable under Article 2.2 as confirmed by the contractor, are processed. During excavation or blasting of materials, the contractor will inspect the site to ensure that stripping and material selection procedures are adequate to prevent inclusion of deleterious materials in processed materials. The Contractor reserves the right to inspect and test the materials at any time during or after production and placement.

B. Placement Quality control: The placement of the materials will be inspected and tested by the contractor during and after placement to ensure that the following requirements are met:

1. Material of the correct type and quality is being placed. Individual pieces greater than or equal to 8 inches in diameter not meeting the requirements noted in Article 2.1.D shall be removed per Paragraph $D$ below. Pockets or concentrated areas of materials, less than 8 inches in diameter, not meeting the requirements of Article 2.1.D shall be removed per Paragraph $D$ below. Individual pieces less than 8 inches in diameter not meeting the requirements of Article 2.1.D may be left in place provided that concentrations do not exist.

2. The material being placed is clean and free of unsuitable material.

3. The material is being loaded, transported and placed in a manner which minimizes segregation.

4. The material is being placed to line and grade within the tolerances and limits designated in Article 3.2 above.

5. The material placed meets the gradation requirements specified.

c. Materials segregated or not placed according to the above requirements shall be regraded or adjusted, using appropriate equipment, to conform with the tolerances and limits given above, at no additional cost to the contractor.

D. The subcontractor may place erosion protection material only at his own risk, if durability test results are not available and approved by the contractor.

E. Materials not meeting the requirements of this section shall be removed and replaced with specified materials at no additional cost to the contractor. Rejected materials shall be disposed of at designated disposal sites and at no additional cost to the contractor. Materials not meeting the 
grading requirements shall be reprocessed or discarded. The contractor may require modification of the processing and grading operations to ensure that the specified grading requirements are met.

F. [During placement of riprap materials, drainage materials, sand blanket, drain rock and bedding materials, the Contractor will perform a minimum of four gradation tests in accordance with the gradation specifications.]* An initial sample shall be obtained and tested during the early stages of placement activities. Additional samples shall be obtained and tested when approximately one-third and twothirds of the total volume of material has been placed, and a final sample shall be obtained and tested near completion of placement activities. [If the total volume of material placed for each class of riprap, drainage materials, sand blanket, drain rock and bedding materials is greater than 30,000 cubic yards, a gradation test shall be performed for each additional 10,000 cubic yards, or fraction thereof placed. ]*

\section{PART 4 - MEASUREMENT AND PAYMENT}

\subsection{MEASUREMENT}

A. Measurement for payment for furnishing and installing the following materials will be by the cubic yards of material placed:

1. Riprap Material, Type A

2. Riprap Material, Type B

3. Riprap Material, Type C

4. Riprap Material, Type D

5. Drainage Material, Type DI

6. Drainage Material, Type D2

[Measurement for payment for sand blanket and drain rock is specified in section 02144 and measurement for payment for liner bedding is specified in section 02216.]*

B. The quantities will be calculated from the lines and dimensions shown on the Subcontract Drawings and/or by using average end area methods from surveys conducted before and after placement for the areal extent of the placement.

* P.I.D. 06-S-17 


\subsection{PAYMENT}

[A.]* Payment for the items of Article 4.1.A above, will be by their applicable unit prices per cubic yards quoted therefor in the Bid schedule. The prices quoted shall include full compensation for furnishing labor, materials, tools, equipment and incidentals and for performing specified work including development of the source (where applicable), obtaining required permits (if applicable), clearing, stripping and excavating; processing the materials; testing and evaluating the materialsi transporting to placement locations; opening and restoring borrow areas; placing, including placing in test fill sections; compacting and consolidating complete in place.

[B. Payment for sand blanket and drain rock is specified in section 02144 and payment for liner bedding is specified in Section 02216.]* 


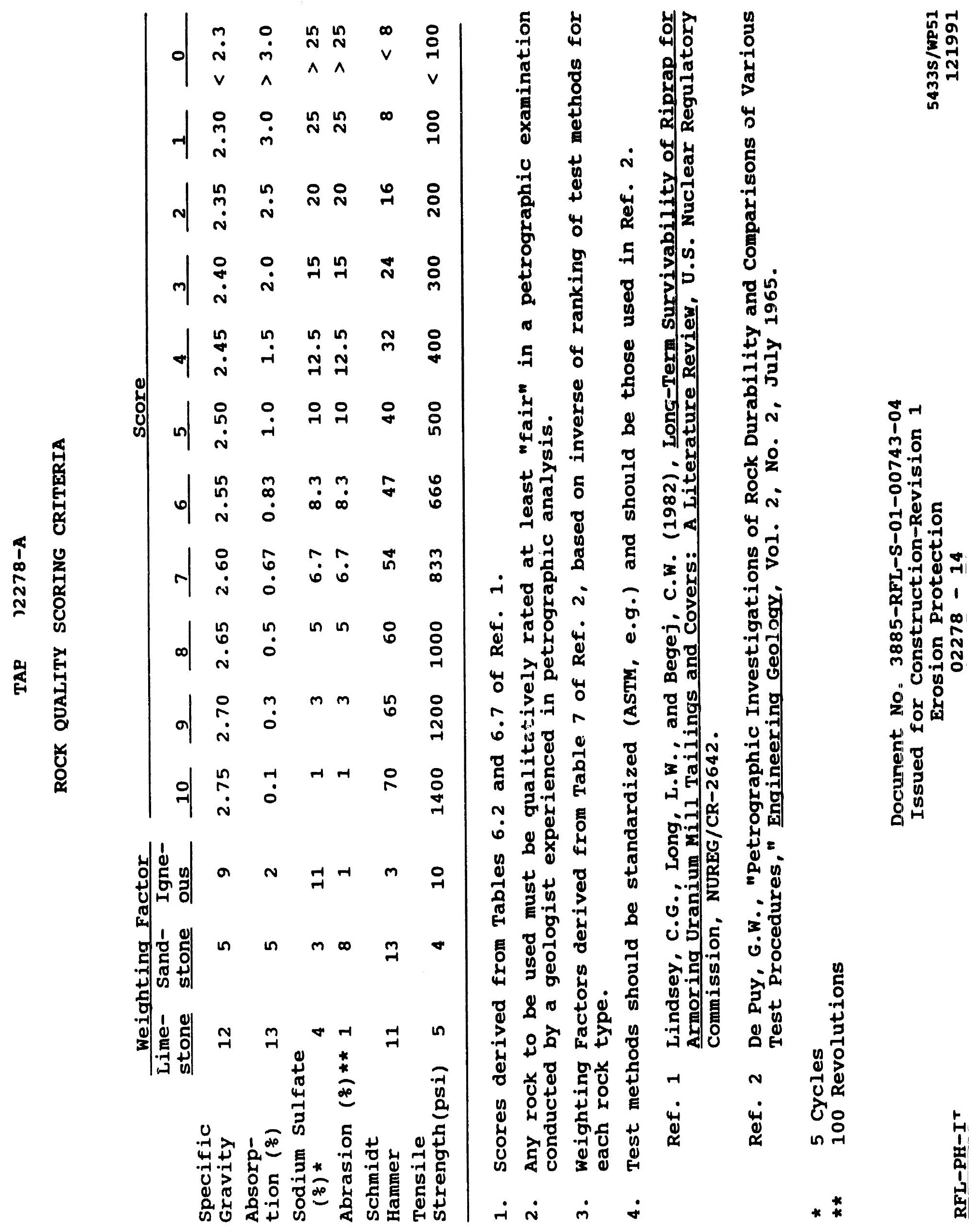


PART 1 - GENERAL

\subsection{SCOPE}

A. This specification section describes the requirements for the construction of bituminous pavement for the access road approach to the decontamination pads at the old and New Rifle processing sites.

B. Bituminous pavement shall be composed of a mixture of aggregate, filler or additives if required, and bituminous material.

\subsection{WORK NOT INCLUDED}

A. Temporary roads as defined in Article SC-1 of the special Conditions.

B. Section 02200 - Earthwork

C. Section 62230 - Aggregate Base

1.3 RELATED WORK

A. Section 01300 - Submittals

B. Section 02200 - Earthwork

1.4 APPLICABLE PUBLICATIONS

A. The Publications listed below form a part of this specification to the extent referenced. The publications are referred to in the text by the basic designation only:

1. American Association of State Highway and Transportation officials (AASHTO):

T30-84 Mechanical Analysis of Extracted Aggregate

T164-86 Quantative Extraction of Bitumen from Bituminous Paving Mixtures (ASTM D2127)

Document No. 3885-RFL-S-01-03682-01

Issued for construction-Revision 1

Bituminous Pavement 
T166-83 Bulk Specific Gravity of Compacted Bituminous Mixtures Using Saturated Surface-Dry Specimens

T168-82 Sampling Bituminous Paving Mixtures (ASTM D979)

2. Asphalt Institute:

MS-2 Mix Design Methods for Asphalt Concrete

3. American Society for Testing and Materials (ASTM):

D290-85 Practice for Bituminous Mixing Inspection

4. Colorado standard specifications

5. Colorado standard Plans

1.5 QUALITY ASSURANCE

A. Pavement:

1. Bituminous paving mixture shall be the product of a bulk asphalt mixing plant regularly engaged in the production of hot-mixed, hot-laid asphalt paving mixtures.

2. Mixing plant may be inspected in accordance with ASTM D290. The inspector shall be provided with means of access to all facilities and processes involved in the production and testing of the paving materials and mixture.

3. After approval of mix design, no change shall be made in types or proportions of materials without written approval of the contractor.

4. Sampling Pavement: The Subcontractor shall remove suitable size samples of the completed pavement from location: designated by the contractor so he may determine the composition, compaction, and density of the pavement. Samples for each day or fraction thereof shall be taken. The subcontractor shall replace the pavement free of charge. If the pavement is deficient in composition ( $t 0.4 \%$ of Design Asphalt Percentage), compaction (95\% Marshall Density), or thickness (1/4" less than that indicated on subcontract Drawings), satisfactory correction shall be made [at no additional cost to the contractor ]*.

* P.I.D. 06-S-17

Document No. 3885-RFL-S-01-03682-01

Issued for Construction-Revision 1 
A. The subcontractor shall submit the following:

1. Product data.

2. Manufacturers' instructions.

3. Paving mix and procedures.

4. Mixes as required for evaluation of the job-mix formula in accordance with the Asphalt Institute Manual Ms-2, Mix Design Methods for Asphalt Concrete, Marshall method of mix design, using Appendix $B$, with bulk specific gravity determined in accordance with AASHTO T166.

5. During the course of the work the subcontractor shall submit to the contractor mixes as required for testing of gradation and bitumen content in accordance with AASHTO T30 and T164 on random samples selected as described in AASHTO T168.

6. Manufacturer's Certifications: Each shipment of material delivered to the project or to storage tanks at mixing plants serving the project shall be accompanied by a certification by the refiner or manufacturer giving the following information:

a. Date, time, point of loading and identification of the hauling unit loaded.

b. Type, grade, temperature and quantity of the material loaded.

c. A batch or lot number by which the material loaded can be identified, with a complete certified analysis conducted by the producer showing that the material meet specifications in all respects.

d. The results of tests of the batch from which the delivery was drawn: The following test values shall be required:

1) Asphalt Cement: Penetration; Kinematic Viscosity at 140 degrees $F$ and at 275 degrees $F$.

7. Job-mix formula for each mix shall be supplied, based on expected production averages. The following shall be established in the formula: 

a. Weight percent of total aggregate finer than each required sieve size.
b. Weight percent of total mix of asphalt cement.
c. Temperature of the mix when placed.
d. Required stability by Marshall Method.

\section{PART 2 - PRODUCTS}

\subsection{EQUIPMENT}

The subcontractor shall provide all equipment and facilities required to perform the work of this specification. The equipment and facilities shall be subject to approval by the contractor.

\subsection{MATERIALS}

Materials, composition of mixtures and job-mix formula shall conform to sections 401.02 through 401.06 and section 411 of the Colorado standard Specifications.

\section{PART 3 - EXECUTION}

\subsection{EARTHWORK AND SUBGRADE PREPARATION}

A. Earthwork and subgrade preparation shall be as specified in Section 02200 .

B. Before placing and spreading subbase and base course material the subgrade shall be cleaned of all foreign substances and shall contain no frozen material. It will be inspected by the contractor for adequate compaction and surface tolerances.

\subsection{CONSTRUCTION OF BITUMINOUS PAVEMENT}

Construction of bituminous pavement shall conform to sections 401.07 through 401.20 of the colorado standard specifications for Hot Bituminous Pavement (HBP), class E. Lift thickness shall be 2 inches. 
3.3 CLEAN-UP AND PROTECTION

A. After completion of paving operations, surfaces shall be cleaned of excess and spilled paving materials. The area around new work shall be well graded to drain, top soiled, fertilized, mulched and reseeded.

B. Vehicular traffic shall be diverted from pavement until it has cooled and hardened.

3.5 MAINTENANCE

The roadway surfaces shall be maintained by the subcontractor in good condition, free of pot holes, ruts and ravels.

3.6 PRIME COAT

Prime coat shall be applied as specified in section 407 of the colorado standard Specifications. Prime coat shall be applied at a rate of 0.3 gallon per square yards.

\subsection{TACK COAT}

Tack coat shall be applied as specified in section 407 of the Colorado standard Specifications. Tack coat shall be applied at a rate of 0.1 galion per square yards.

\section{PART 4 - MEASUREMENT AND PAYMENT}

\subsection{MEASUREMENT}

Measurement for payment for construction of bituminous pavement for the access road approach to the decontamination pads at the old and New Rifle processing sites will be by the tons of bituminous concrete furnished and placed. separate measurement for payment will not be made for bituminous material, prime coat, tack coat, or painting or incidentals including, but not limited to, temporary signs, detours, lane shut downs and the like. 


\subsection{PAYMENT}

A. Payment for construction of bituminous pavement [for]* the access road approach to the decontamination pads at the old and New Rifle processing sites will be by the unit price quoted per ton of bituminous concrete. Separate payment will not be made for bituminous material, prime coat, tack coat or pavement marking or incidentals including, but not limited to, temporary signs, detours, [lane shut downs]*, and the like.

B. The price quoted shall include full compensation for furnishing all labor, materials, tools, equipment, and incidentals, for doing all work involved in constructing bituminous pavements complete in place including subgrade preparation and for protection and maintenance of completed work, as shown on the subcontract Drawings, as specified in these specifications and as required by the site Manager.

END OF SECTION 02511

* P.I.D. 06-S-17

Document No. 3885-RFL-S-01-03682-01

Issued for Construction-Revision 1

Bituminous Pavement 


\section{SECTION 02771}

MEMBRANE LINER

PART 7 - GENERAI

1.1 SCOPE

This specification section describes the requirements for furnishing and installing membrane liner systems for disposal cell, ditches, wastewater retention basins, spillways and temporary ditches at Estes Gulch Disposal site.

\subsection{SYSTEM DESCRIPTION}

A. Liner system shall consist of liner, adhesives and accessories required for sterilizing ground and installing liner, vents and other appurtenances. In addition, the liner system in the disposal cell shall consist of a liner, a geotextile and a sand bedding layer.

B. Low level radioactive tailings will be placed on the liner in the disposal cell.

c. The ditches, retention basins, and spillways, where lining is required, will carry water produced from stormwater runoff, decontamination and dewatering operations, including minor amounts of sediment.

D. With the exception of the liner installed within the Disposal Cell, all other liners will be installed without a protective earthen cover and will be exposed to all natural weathering elements, such as direct sunlight, cold and hot air temperatures, snow, ice and wind.

\subsection{RELATED WORK}
A. Section 01300 - Submittals
B. Section 02050 - Demolition
C. Section 02200 - Earthwork
D. Section 02216 - Foundation Preparation for Disposal Cell Liner




\subsection{APPIICABLE PUBLICATIONS}

A. The Publications listed below form a part of this specification to the extent referenced. The Publications are referred to in the text by the basic designation only:

1. American Society for Testing and Materials (ASTM):

D638 Test Method for Tensile Properties of Plastics [(As modified by NSF 54)]*

[Text Deleted]*

D746 Test Method for Brittleness Temperature of Plastics and Elastomers by Impact

[D751 Standard Test Methods for Coated Fabrics

(As modified by NSF 54 )] *

D792 Test Methods for Specific Gravity and Density of Plastics by Displacement

D1004 Test Method for Initial Tear Resistance of Plastic Film and sheeting

D1204 Test Method for Linear Dimensional Changes of Nonrigid Thermoplastic sheeting or Film at Elevated Temperature

D1238 Test Method for Flow Rates of Thermoplastics by Extrusion Plastomer

[Text Deleted]*

D1603 Test Method for Carbon Black in olefin Plastics

D1693 Test Method for Environmental Stress-Cracking of Ethylene Plastics (R 1980) [(As modified by NSF 54$)]$ *

[D3015 Recommended Practice for Microscopical Examination of Pigment Dispersion in Plastic Compounds (As modified by NSF 54 )

D4437 Standard Practice for Determining the Integrity of Field Seams Used in Joining Flexible Polymeric Sheet Geomembranes (As modified by NSF 54)] *

* P.I.D. 06-S-17 
2. National Sanitation Foundation (NSF):

[NSF 54-1991 Flexible Membrane Liners

(Revised May 1991) ]*

3. Federal standards (FS):

[FTMS 101 Test Methods for Puncture Resistance and Elongation Test (Method 2065)] *

\subsection{QUALITY ASSURANCE}

A. Manufacturer: The manufacturer of the liner shall have manufactured in excess of $10,000,000$ square feet of membrane liner. The manufacturer shall also certify in writing that the liner meets or exceeds the NSF standard 54 physical properties as specified in this section, and shall withstand a minimum of 20 years of outdoor weathering without cover. The certification shall also state that the liner material is formulated from 100 percent virgin domestic, first quality raw materials.

B. Fabricator: The liner fabricator shall have fabricated in excess of $10,000,000$ square feet of liner.

c. Installation: The Installation Supervisor shall have supervised installation of lining material in excess of $1,000,000$ square feet of liner.

1.6 SUBMITTALS

A. General submittal requirements are specified in section 01300 .

B. The subcontractor shall submit the following to the contractor for submittal to the Colorado Department of Health for review and approval 30 days before placement of the material:

1. Product data.

2. Samples of material and accessories.

3. Certificate signed by the manufacturer stating that the system proposed meets the specification.

* P.I.D. 06-S-17

Document No. 3885-RFL-S-01-00744-04

Issued for Construction-Revision 1 Membrane Liner 
4. [Six sets of full and complete drawings showing liner installation details.]* These drawings shall show as a minimum, the panel layouts, liner hold-downs and gas vent details as required for liner installation. Iiner holddowns shall have sufficient weight to prevent uplift and billowing of the liner from wind velocities up to $50 \mathrm{mph}$.

5. Fabricator's or manufacturer's certified installation instructions.

6. Test reports.

7. Qualifications of installer and supervisor in accordance with the requirements of Article 1.5.C.

8. Certification from a recognized independent testing laboratory that the liner meets the requirements of this specification and is suitable for its intended purpose.

\subsection{SITE CONDITIONS}

The site is at an approximate elevation of 6000 feet and is located near Rifle, Colorado. Temperatures may vary from a low of $-40^{\circ} \mathrm{F}$ to a high of $105^{\circ} \mathrm{F}$. Wind speeds may reach 50 mph. The liner in the disposal cell is required to function for at least 20 years.

\subsection{WARRANTY}

A. Liner materials and factory seams shall be warranted free of defects in materials and workmanship for a period of 20 years from the date of acceptance. Installation and field seams shall be warranted free of defects for a period of 20 years from the date of acceptance.

B. Upon written notification by the contractor, the Subcontractor shall promptly and completely repair or replace defective lining materials on site which become apparent during such 20-year period. Such repair or replacement shall be done at no cost to the contractor. The subcon- tractor shall be responsible for removal and proper dis-posal of all liquids, dirt, soil, or contaminated materialsrequired to enable him to carry out the necessary repairs.

c. The subcontractor shall provide a written warranty that he has been approved by the liner manufacturer to perform installation of the liner.

* P.I.D. 06-S-17

Document No. 3885-RFL-S-01-00744-04

Issued for Construction-Revision 1 Membrane Liner 


\section{PART 2 - PRODUCTS}

\subsection{ACCEPTABLE MANUFACTURERS}

The liner material shall be the product of (1) a manufacturer successfully engaged in the business of manufacturing liner materials for the last five years, and (2) a manufacturer meeting the requirements of Article $1.5 . \mathrm{A}$ above.

\subsection{MATERIAL}

A. [Liner materials shall consist of high density polyethylene (HDPE) specifically compounded to conform to the material properties set forth in the National Sanitation Foundation Standard NSF 54-1991.]*

B. The liner material base resin shall be unreinforced HDPE and shall contain not less than 2 percent carbon black as defined in [ASTM D1603]*. The resin shall be sampled and tested prior to fabrication of the liner sheets in accordance with ASTM D1238 and D1603 to determine resin index properties and to verify consistent product quality. Resins used for weld materials shall have the same properties as the resin used for liner fabrication.

c. The fabricated liner material shall meet the following criteria:

\section{Property}

Gauge (nominal)

[Thickness

(mils minimum)

[Density

[Other tests as specified in

NSF 54-1991]*

* P.I.D. $06-S-17$
Specificatiol for Liner Placed in

Specification for Liner Placed In Test Method Disposal Cell

60

ASTM D751

54

ASTM D792

0.940

Method A
40

$36]$ *

Retention Basins, Ditches and spillways

$0.940]$ * 
[Text Deleted]*

D. The liner shall have a smooth uniform surface with no visible defects and shall be free of holes, blisters, gels, undispersed ingredients and any contamination or defect that may affect its serviceability. The liner shall be uniform in thickness with a maximum 10 percent deviation from the nominal thickness. The edges shall be straight and free of nicks and cuts. Inspection for pinholes shall be made prior to shipment to the jobsite.

[E. The liner material shall be manufactured to a minimum 15-foot seamless width. Labels on the roll shall identify the thickness, length, width, and manufacturer's mark number.]*

\subsection{GEOTEXTILE FABRIC}

A. Geotextile fabric shall be a high-modulus woven material.

B. The material shall be free of tears, punctures, undispersed raw materials, foreign matter, and any other defects.

c. Permeability: The material shall have a coefficient of permeability, $k$, not less than $0.005 \mathrm{~cm} / \mathrm{sec}$ when tested by the constant head method per ASTM D4491.

D. Material Properties: The materials shall comply with the minimum mechanical properties specified below for the grade of fabric indicated on the Drawings, when tested in the weakest principal direction.

Medium

Strength

1. Grab Strength (1b.)

ASTM D1682

2. Elongation $(z)$

ASTM D1682

3. Mullen Burst Strength (1b.) ASTM D3786

4. Puncture Strength (1b.) ASTM D751
90

15

210

40
High

strength

180

290

75

* P.I.D. 06-S-17

Document No. 3885-RFL-S-01-00744-04

Issued for Construction-Revision 1 Membrane Liner 


\subsection{FABRICATION}

The roll goods shall be factory fabricated into optimum sized panels up to 20,000 square feet, using an approved seaming method as prescribed by the manufacturer. When the seam is tested for shear and peel, failure of the material including the seam shall not occur at the bonded surfaces.

\section{PART 3 - EXECUTION}

\subsection{GENERAL}

The liner systems shall be installed as shown on the Subcontract Drawings and as recommended by the manufacturer and the fabricator.

3.2 GROUND SURFACE PREPARATION FOR IINER PLACED IN DITCHES, RETENTION BASINS, SPILLWAYS AND TEMPORARY DITCHES AT ESTES GULCH DISPOSAL SITE

A. [Surfaces to be lined shall be smooth and free of all rocks larger than $3 / 8$ inch, and all roots, sharp objects, or debris of any description. The subgrade shall provide a firm, unyielding foundation for the materials, with no abrupt changes or breaks in grade. No standing water or excessive moisture will be permitted during placement.]* If the liner is not applied within 15 days of surface preparation, the surface shall be protected against growth of vegetation by the application of a suitable short-lived soil sterilant as approved by the contractor. The soil sterilant used shall be compatible with the liner material to ensure that the liner is not damaged.

B. [Certification shall be required from the Installation Supervisor stating that the surface on which the liner is to be placed is acceptable.]* No installation of lining shall commence until this certification is furnished to the contractor. The receiving surface shall be kept in the accepted condition until the installation of the lining is accomplished.

3.3 GROUND SURFACE PREPARATION FOR LINER PLACED IN DISPOSAL CELL See section 02216 .

* P.I.D. 06-S-17 


\subsection{GEOTEXTILE FABRIC}

A. Installation of Geotextile Fabric: Geotextile fabric shall be installed in accordance with the manufacturer's directions and the details shown on the subcontract Drawings.

\subsection{HDPE LINER}

A. Field joints shall be made with overlapping adjacent sheets and inserting a ribbon of fusion joining resin between the overlapping sheets or over the joint between them. The minimum width of overlap of field seams for fusion welding shall be 3 inches. An alternate seaming procedure as recommended by the manufacturer or fabricator such as the hot wedge method may be proposed for the Contractor's approval. [The minimum width of overlap of field seams shall be 4 inches. ]*

1. Joints between liner sheets shall be field welded using the fabricator's fusion joining apparatus and technique. The joining procedure shall consist of softening the liner material by heated air. Directly following the application of heat, a minimum 1-1/2 inch wide hot strip of the same HDPE from which the sheet is made shall be extruded between the overlapping sheets. The overlapping sheets shall then be pressed together with a minimum pressure of $14 \mathrm{psi}$ to form the fusion joint.

2. Penetrations through the liner for pipes, flashings, patches, and the like shall be field welded using a fusion joint gun. The joining procedure shall consist of softening the liner material by heated air. Directly following the application of heat, a hot strip of the same material from which the sheet is made shall be extruded over the joint to produce the fusion joint.

3. Prior to fusion joining, all areas to become joint interfaces shall be clean.

4. Fusion joining shall not take place unless the sheet is dry and shall not be attempted when the ambient temperature is below $45^{\circ} \mathrm{F}$ or above $90^{\circ} \mathrm{F}$ as determined by the contractor.

* P.I.D. 06-S-17 
A. HDPE Liner:

1. All fusion joined seams shall be visually examined and probed for voids or imperfect bonds.

2. All seams made for the HDPE liner shall be tested using vacuum testing. Vacuum testing shall consist of placing a rectangular box (approximately 30 inches long) into the liner seam. The suction chamber shall be connected to the vacuum pump. A foaming agent shall be applied to the seam area under test to indicate possible leaks. The seam shall be maintained under 5 psig suction for a minimum of 10 seconds, and certification given to the Contractor that the seams will provide a film tearing bond. The test areas shall have a minimum of 3 -inch overlap from the previous test section.

3. Defects found during the testing shall be repaired and retested. Such tests and adjustments shall be repeated until, in the opinion of the Contractor, the repairs are satisfactory and complete. All repairs shall be made by the subcontractor at no additional expense to the Contractor.

4. The Subcontractor shall furnish to the Contractor, on a daily basis, if requested, seam samples for testing cut From that days installation. The samples may be tested to determine strength and durability. Any seams not meeting the requirements specified herein shall be repaired by the subcontractor at no additional expense to the contractor.

5. The Subcontractor shall repair all areas damaged by sampling immediately after the sample is taken. The repairs shall be made at no additional expense to the contractor.

\subsection{GAS VENTS AND IINER HOLD-DOWNS}

A. Gas vents as recommended by the manufacturer and the fabricator and approved by the contractor shall be installed in the liner. Vents shall have a minimum diameter of 4 inches and a maximum spacing of 50 feet on centers.

B. Liner hold-downs, as recommended by the manufacturer and the fabricator and approved by the contractor, shall be installed over the liner on the embankment and in the disposal cell.

Dccument No. 3885-RFL-S-01-00744-04

Issued for Construction-Revision 1 Membrane Liner 
The holddowns shall be placed on maximum 30-foot centers or over every field seam, whichever is closer.

\subsection{ANCHORING}

During installation, necessary precautions shall be taken to insure the liner will not be damaged or moved by wind, rain or dust. The liner shall be installed in such a manner that the liner will be protected from damage or movement by wind, water, and dust. Venting to prevent damage to the liner shall be provided in accordance with the manufacturer's recommendations. Riprap protection shall be provided on a portion of the retention basin spillway liner as shown on the Subcontract Drawings.

\subsection{MAINTENANCE}

The subcontractor shall maintain and if required, repair synthetic membrane to provide protection from runoff erosion and contamination.

3.10 REMOVAL AND DISPOSAL OF MEMBRANE LINER [INCLUDING RIPRAP PROTECTION INCIDENTAL TO WORK]*

After the completion of the construction phase or when the retention basin is no longer required, the synthetic membrane shall be removed, decontaminated or demolished and disposed of as specified in section 02050 and as required by the contractor. The liner in the disposal cell shall not be removed.

\section{PART 4 - MEASUREMENT AND PAYMENT}

\subsection{MEASUREMENT}

A. Measurement for payment for furnishing and installing the following items of membrane liner and geotextile fabric for disposal cell and membrane liner for wastewater retention basins, ditches and spillways at Estes Gulch site will be by the net syuare yards of the completed liner or geotextile fabric installation. The quantities for payment will be calculated from the lines and dimensions shown on the Subcontract Drawings. Overlaps shall not be measured for quantity calculations. The surfaces shall be measured parallel to the liner or geotextile fabric material installation.]*

*P.I.D. 06-S-17

Document No. 3885-RFL-S-01-00744-04

Issued for Construction-Revision 1

Membrane Liner 
1. Liner for disposal cell.

2. Geotextile fabric for disposal cell.

3. Liner for wastewater retention basin ditches and spillways.

B. Measurement for payment for ground surface preparation for disposal cell liner shall be as specified in section 02216.

C. Measurement for payment for preparation of subgrade for membrane liner installed in retention basins, ditches and spillways shall be as specified in section 02200. [Riprap protection will not be measured for separate payment. All costs in connection therewith shall be considered incidental to the lining work.]*

\subsection{PAYMENT}

A. Payment for the items of 4.1.A above will be by the applicable unit price per square yard quoted therefor in the Bid Schedule. The prices quoted shall include full compensation for furnishing all labor, materials, tools, equipment, Installation supervisor, incidentals and for performing all work including, but not limited to, installation, seaming, installation of gas vents and liner hold-downs, excavation, backfilling of anchor trenches, [riprap protection,]* maintaining, removal, demolition and disposal of the liner as required and as specified.

B. Payment for ground surface preparation for disposal cell liner shall be as specified in section 02216 .

c. Payment for preparation of subgrade for membrane liner installed in retention basins, ditches and spillways shall be as specified in section 02200 .

END OF SECTION 02771

* P.I.D. 06-S-17 


\section{SECTION 02800}

ROAD SIGNS

\section{PART 1 - GENERAL}

\subsection{SCOPE}

A. [This specification section describes the requirements for furnishing and installing No Parking and No Entry signs and supplemental plates at the intersection of Highway 6 and the west access road to old Rifle processing site.]*

B. The Work shall conform to the following:

1. Locations of signs as shown on the subcontract Drawings. Layout and wording of signs and sign dimensions shall be as specified in the Manual on Uniform Traffic Control Devices for streets and Highways.

2. Installation details as shown on the colorado standard Plans.

3. Colorado standard specifications cited in this section.

1.2 APPLICABLE PUBLICATIONS

A. The Publications listed below form a part of this specification to the extent referenced. The publications are referred to in the text by the basic designation only:

1. State of Colorado, Division of Highways:

a. Standard specifications for Road and Bridge Construction, 1985 Edition, (Colorado standard Specifications). All references to "Engineer" shall mean "Site Manager"; all references to "Division" shall mean "Contractor": and all references to "Contractor" shall mean "Subcontractor". The provisions for measurement and payment shall not be applicable. All references to "special provisions" shall not be applicable. Measurement and payment provisions shall be as specified in this section.

* Revision

Document No. 3885-RFL-S-01-03684-00

Issued for Construction-Revision 0

Road Signs 
b. Standard Plans, M\&S Standards, January 1982, (Colorado standard Plans).

2. American National Standards Institute (ANSI):

D6.1-1978 Manual on Uniform Traffic Control Devices for streets and Highways

B. In case of conflict between colorado standard specifications and ANSI D6.1-1978, the provisions of Colorado standard Specifications will take precedence.

\section{PART 2 - PRODUCTS}

\subsection{MATERIALS}

A. The signs shall conform to the applicable provisions of the following colorado standard Plans:

1. Sign Posts: $w-2$ type conforming to the details shown on standard Plan s-614-2.

2. Sign Panels: Class I, Aluminum, conforming to standard Plan s-614-2.

\section{PART 3 - EXECUTION}

\subsection{INSTALIATION}

A. Installation of signs shall conform to the following:

1. Applicable provisions of the subsection 614.09, signing, of the Colorado standard specifications.

2. Applicable details shown on the Colorado standard Plans, M\&S Standards, Numbers s-614-1 and s-614-2.

3. Locations of the signs as shown on the subcontract Drawings.

\section{PART 4 - MEASUREMENT AND PAYMENT}

4. 1 MEASUREMENT

Measurement for payment for road signs will be by the lump sum. 


\subsection{PAYMENT}

Payment for road signs will be by the lump sum price quoted therefor in the Bid schedule. The price quoted shall include full compensation for furnishing all labor, materials, equipment, tools, incidentals and accessories, and for performing all work including, but not limited to, designing, fabricating, installing and maintaining signs complete in place including all work such as excavating, concreting, and the like.

END OF SECTION 02800 
SECTION 02832

CHAIN LINK FENCE AND GATES

\section{PART 1 - GENERAL}

1.1 SCOPE

This specification section describes the requirements for furnishing, installing, maintaining, removal and disposal of chain link fencing including gates, posts, fittings, hardware, and concrete footings as shown on the subcontract Drawings.

1.2 RELATED WORK
A. Section 01300 - Submittals
B. Section 02833 - Woven Wire Fences
c. Section 02835 - Deer Fence and Gates

1.3 DEFINITIONS

Definitions of fencing components shall be in accordance with ASTM F552.

\subsection{APPLICABLE PUBLICATIONS}

A. The Publications listed below form a part of this specification to the extent referenced. The publications are referred to in the text by the basic designation only:

1. Chain Iink Fence Manufacturers Institute:
a. Standards for Galvanized steel Chain Link Fence Fabric
b. Industrial steel Specifications for Fence Posts, Gates, and Accessories
c. Standards for chain Link Fence Installation 
2. American Society for Testing and Materials (ASTM):

A53-89 Specification for Pipe, Steel, Black and HotDipped Zinc-Coated Welded and Seamless (Rev. B)

A90-81 Test Method for Weight of Coating on zincCoated (Galvanized) Iron or steel Articles

A123-89 Standard Specification for Zinc (Hot-Dip Ga1vanized) Coatings on Iron and steel Products

A153-82 Specification for zinc Coating (Hot-Dip) on Iron and steel Hardware

A239-89 Test Method for Locating the Thinnest Spot in a zinc (Galvanized) Coating on Iron or steel Articles by the Preece Test (Copper sulfate Dip)

A370-89 Standard Test Methods and Definitions for Mechanical Testing of Steel Products

A392-89 Specification for Zinc-Coated Steel Chain-Link Fence Fabric

C33-86 Specification for Concrete Aggregates

C94-89 Standard Specification for Ready-Mixed Concrete (Rev. B)

150-89 Standard Specification for Portland Cement

F552-88 Standard Definitions of Terms Relating to Chain Link Fencing (Rev. B)

3. [State Department of Transportation, Division of Highways, State of Colorado:]*

a. Standard Specifications for Road and Bridge Construction (Colorado standard Specifications). For the purposes of this subcontract, all references to "Engineer" shall mean "Site Manager"; all references to "Division" shall mean "Contractor"; and all references to "Contractor" shall mean "Subcontractor". The provisions for measurement and payment shall not be applicable. All references to "special provisions" shall not be applicable. Measurement and payment provisions shall be as specified in this section.

* P.I.D. 06-S-17

Document No. 3885-RFL-S-01-00745-O4

Issued for Construction-Revision 1

Chain Link Fence and Gates 
b. Standard Plans, M\&S Standards, January 1982 (Colorado standard Plans)

\subsection{SHOP DRAWINGS}

Pursuant to the provisions of section 01300, three blackline or blue line prints and a reproducible transparency of fully detailed shop drawings of fence, gate and hardware, including footings and installation details, shall be submitted to the contractor for review.

\section{PART 2 - PRODUCTS}

\subsection{MATERIALS}

A. General: Fencing shall include fabric, framework, concrete footings, gates, closure at grade depressions, hardware, and all appurtenances and accessories as required for a complete installation. All members, except fittings, shall be steel, hot-dip galvanized after fabrication. Fittings shall be malleable iron, wrought iron, or pressed steel, hot-dip galvanized after fabrication. Fence fabric and tension wire shall be zinc-coated as specified. Heights of fences shall be as shown on the subcontract Drawings. Tolerance for fabric height is \pm 1 inch.

B. Fence Fabric: No. 9 gage, chain-link steel wire helically woven into 2 -inch diamond mesh, hot-dip galvanized, conforming to ASTM A392. Fabric shall be twisted and barbed on the top selvage and knuckled on the bottom selvage. Loops of knuckled selvage shall be closed or nearly closed with a space not exceeding the diameter of the wire. The twisted wire shall be twisted in a closed helix of 1-1/2 machine turns equivalent to three full twists, and cut at an angle to provide sharp barbs. The wire ends beyond the twist shall be at least 1/4-inch long. Steel wire for the fabric, when drawn to the wire gage specified, shall have a minimum tensile strength of 75,000 pounds per square inch when tested in accordance with ASTM A370. Coating or fabric shall be Class II, 2.0 ounces of hot-dip zinc galvanizing per square foot of uncoated wire surface. The weight of crating shall be determined in accordance with the requirements of ASTM A90. The standard length of fabric roll shall be 50 linear feet \pm 1 percent. Each roll shall be a one-piece length. Tolerance for fabric heights shall be plus or minus 1 inch.

Document No. 3885-RFL-S-01-00745-04

Issued for Construction-Revision 1

Chain Link Fence and Gates 
c. Posts:

1. Post shall be schedule 40 galvanized pipe. Use shall be in accordance with the following table except as noted on the Subcontract Drawings. All pipe shall conform to ASTM A53 for weight and galvanized coating. Line post shall be spaced at no more than 10-foot centers.

Post Type and Shape

2. End, Corner and Pull Posts: Round

3. Intermediate or Line Posts: Round

4. Gate Posts:

single Leaf Gate opening width:
Nominal Pipe size, Inches

2.5

2.0
6 Feet and Less: Round
2.5
6 to 13 Feet: Round
3.5
13 to 18 Feet: Round
6.0
Over 18 Feet: Round
8.0

D. Post-Bracing Assembly: Horizontal braces shall be 1-1/4 inch Schedule 40 steel pipe, conforming to ASTM A53. Diagonal truss type braces shall be 3/8-inch diameter galvanized steel rods with turnbuckle adjustment. couplings, fittings, and attachment accessories shali be included as required. Horizontal braces (intermediate rails) shall be provided at all corners, terminals, pulls, and at gate pusts.

E. Wire Ties and clips: Wire ties or clips shall be provided for attaching fabric to line posts, top rail, or tension wire. Wire ties and clips shall be at intervals not greater than 15 inches when attaching fabric to line posts, and the space interval shall not exceed 24 inches when attaching fabric to top rails or tension wire. Wire ties and clips shall be not less than the fabric wire gage 
size and of the same material and coatings. The minimum weight for $z$ inc coated wire ties and clips is 0.8 ounces of zinc per foot of coated surface area.

F. Tension Wire, zinc-coated steel: Tension wire for top and bottom edge support of fence fabric shall be No. 7 gage marcelled or crimped coil spring hard tempered carbon steel wire with minimum tensile strength of $70,000 \mathrm{psi}$, and $z$ inc coating of not less than 1.20 ounce per square foot of coated area.

G. Post Caps: Post caps shall be standard malleable iron, wrought iron, or pressed steel, galvanized, designed as a weathertight closure cap for tubular posts.

H. Stretcher Bars: stretcher bars shall be one-piece lengths equal to full height of fabric with a minimum crosssection of $3 / 16$ inch by $3 / 4$ inch. Provide one stretcher bar for each gate and end post, and 2 for each corner and pull post.

I. Stetcher Bar Bands: Bands shall be heavy pressed steel, or malleable iron, spaced not over 15 inches on center to secure stretcher bars to end, corner, pull, and gate posts.

J. Gates:

1. Gates shall be of chain link fabric, single-leaf or double-leaf swing type as shown on the subcontract Drawings and furnished complete with all hardware and accessories as required. For this subcontract, the size of the gate shall be measured in terms of the length of each leaf measured in feet. The height of the leaf for all sizes shall be 6 feet.

2. Gate Frames: Frames shall be round pipe to match posts in accordance with the following table:

Gate size

Nominal Pipe size

Leaf width

8 Feet or Less: Rounáa

1-1/4 Inch Schedule 40

Leaf Width

Over 8 Feet:

Round

1-1/2 Inch schedule 40

Document No. 3885-RFL-S-01-00745-04

Issued for Construction-Revision 1

Chain Link Fence and Gates 
3. Fabrication of Gates: Assemble gate frames by welding or with fittings and rivets for rigid connections. When fittings are used as the construction method for gate frames, the frames shall be fitted with 5/16-inch minimum diameter truss rods. The frames shall be $z$ inc-coated after fabrication. When frames are not $z$ inc-coated after fabrication the welds shall be coated with a zinc rich paint. Use same fabric as for fence. Install fabric with stretcher bars at vertical edges, and tie wires at top and bottom edges. Attach stretcher bars to gate frame at not more than 15 inches on center. Attach hardware with rivets or by other means which will provide security against removal or b-eakage. Provide additional horizontal and vertical members to ensure proper gate operation and for attachment of fabric, hardware, and accessories. Provide diagonal crossbracing consisting of 3/4-inch diameter adjustable length truss rods on gates where necessary to provide frame rigidity without sag or twist. All gates shall be constructed so that they may be operated by one person.

4. Gate Hardware: Provide the following hardware and accessories for each gate:

a. Gate Hinges: Gate hinges shall be of adequate strength for the gate, and shall have large bearing surfaces for clamping or bolting in position. Hinge action shall be such that gates may be easily opened and closed by one person. Hinges shall provide for full $180^{\circ}$ swing of gate leaf.

b. Latch: Forked type or plunger-bar type to permit operation from either side of gate. Provide padlock eye as integral part of latch. Locking devices shall be constructed so that the center drop rod or plunger bar cannot be raised when locked.

c. Keeper: Provide keeper, which automatically engages the gate leaf and holds it in the open position until it is manually released, for each gate leaf.

d. Double Gates: Provide gate stops for double gates, consisting of mushroom type or flush plate with anchors. Set in concrete to engage the center drop rod or plunger bar. Provide locking device and padlock eyes as an integral part of the latch, requiring one padlock for locking both gate leaves. 
K. Accessories: Furnish all miscellaneous materials and accessories, ties, clips, anchors and fastenings as required for a complete installation. Unless otherwise specified, all ferrous items shall be hot dip zinc-coated with an average weight of not less than 1.2 ounces of $z$ inc per square foot of coated surface area.

L. Galvanizing:

1. Fence and gate framework, hardware and appurtenances shall be hot dip galvanized per ASTM A53, A123, or A153 as applicable.

2. Galvanizing of wire fabric shall be after weaving in accordance with ASTM A392, immersions when tested in accordance with ASTM A239.

\subsection{FABRICATION}

Chain link fencing shall be fabricated and pre-assembled by the manufacturer in the factory or shop as far as practicable.

\subsection{CONCRETE}

Concrete: ASTM C94; 2500 psi at 28 days; normal Portland cement conforming to ASTM C150; 3-inch slump; maximum 1-inch size aggregates conforming to ASTM C33; and clean water. The subcontractor shall submit a mix design to the Contractor for approval.

\section{PART 3 - EXECUTION}

\subsection{INSTALLATION}

A. Installation of fencing shall be in accordance with the subcontract Drawings, shop drawings, and the manufacturer's detailed installation drawings, instructions, and recommendations. All posts shall be plumb and rigid after installation. Chain-link fabric shall be smooth and uniformly stretched tight and straight. Tension wires shall be pulled taut.

B. Chain-link fabric shall be extended to provide approximately A inches clearance to the surfaces of grade 
depressions, drainage swales or ditches. The extended fabric shall be the same piece of the fencing material or a piece of fabric securely attached or welded to adjacent fabric of the fencing. A stretcher bar shall be provided through the vertical height of the fence at the lowest point in the depression to stiffen the extended fabric. The stretcher bars shall be threaded through and attached to the fabric by wire ties. At drainage ditches or swales, no line posts shall be installed within 5 feet of the centerline of the drainage ditches or swales. Iine posts shall be spaced evenly from the centerline of the ditch or swale.

c. Gates shall be installed plumb, level, and secure for full opening without interference. Install ground-set items in concrete for anchorage as recommended by the fence manufacturer. Adjust hardwaxe for smooth operation and lubricate. Gates shall operate smoothly and easily to minimize noise.

D. At the locations shown for fence repair, the existing fence shall be stretched, posts replaced, fabric replaced, and other repairs made as required to bring it to a serviceable condition.

E. All posts shall be embedded into concrete except intermediate or line posts, which may be mechanically driven 3 feet 6 inches into the ground, as shown on the subcontract Drawings.

F. Dimensions of arill holes for post footings and concrete embedment of the posts shall be as shown on the subcontract Drawings.

G. Line posts shall be spaced at no more than 10-foot centers.

H. Corner posts shall be installed at all changes in direction where the deflection angle exceeds 30 degrees.

\subsection{CONCRETE PLACEMENT}

Concrete shall be placed around posts in a continuous pour. Each post shall be checked for vertical and top alignment, and shall be held in position during placement and finishing operations. 
The fence and gates constructed under the subcontract shall be maintained during the term of the subcontract and later removed and disposed of as subcontractor's property when no longer required.

\section{PART 4 - MEASUREMENT AND PAYMENT}

\subsection{MEASUREMENT}

A. Measurement for payment for furnishing and installing chain link fencing will be by the linear feet of fence installed as shown on the Subcontract Drawings. Measurements will be made along the top of the fence to the nearest foot.

B. Measurement for payment for furnishing and installing following chain link gates will be by the number of each size and type of gate installed. For payment purposes each gate leaf will be considered as a gate unit:
1. Size: 3 feet long.
2. Size: 13 feet long.
3. Size: 16 feet long.
4. Size: 20 feet long.

\subsection{PAYMENT}

A. Payment for furnishing and installing chain link fencing will be by the unit price per linear foot quoted therefor in the Bid schedule.

B. Payment for furnishing and installing chain link gates will be by the unit price per each type and size quoted therefor in the Bid Schedule.

C. Unit prices quoted shall include full compensation for furnishing labor, materials, tools, equipment and accessories, and for performing all work including, but not limited to, clearing, stripping, tree removal, excavation, maintenance, removal and disposal of fence and gates.

END OF SECTION 02832 


\section{PART 1 - GENERAL}

\subsection{SCOPE}

This specification section describes the requirements for furnishing, installing, maintaining, removal and disposal of rectangular woven wire fence, including relocation of existing fences, as shown on the subcontract Drawings and as specified in this section.

\subsection{APPLICABLE PUBLICATIONS}

A. The Publications listed below form a part of this specification to the extent referenced. The Publications are referred to in the text by the basic designation only:

1. American Society for Testing and Materials (ASTM):
A116-81
Specification for Zinc-coated (Galvanized) Steel Woven Wire Fence Fabric
A121-86 Specification for Zinc-Coated (Galvanized) steel Barbed wire
C33-86 Specification for Concrete Aggregates
C94-89 Standard Specifisation for Ready-Mixed Concrete (Rev. B)
c150-89 Standard Specification for Portland Cement

\section{PART 2 - PRODUCTS}

\subsection{MATERIALS}

A. Fencing shall include rectangular woven wire, posts, barbed wire, and all appurtenances and accessories required for complete installation. 
B. Barbed wire shall conform to the requirements of ASTM A121, and shall consist of [two]* lines of double stranded 12-1/2gage diameter, class 3 coating, galvanized wire either 2point or 4-point barbs spaced at 5-inch intervals.

C. Rectangular woven wire shall be 12-1/2-gage galvanized steel wire conforming to the requirements of ASTM A116, Class 3 coating. The height shall be [24 inches]* consisting of eight horizontal wires with vertical stays spaced 6 inches apart.

D. Line post shall be tee, channel or U-bar shape, 1.33 lbs. per foot.

E. Braces shall be 1-1/4-inch Schedule 40 steel pipe, or steel angle section, $2 \times 2 \times 3 / 16$ inches.

F. End, corner and pull posts shall be 2 -inch Schedule 40 steel pipe, or steel angle section $2-1 / 2 \times 2-1 / 2 \times 1 / 4$ inches.

G. Hardware for connecting members shall conform to commercial standards.

\subsection{CONCRETE}

Concrete: ASTM C94; 2500 psi at 28 days; normal Portland cement conforming to ASTM C150; 3-inch slump; maximum 1-inch size aggregates conforming to ASTM C33; and clean water. The Subcontractor shall submit a mix design to the contractor for approval.

\section{PART 3 - EXECUTION}

\subsection{INSTALLATION}

A. General: Wire fence shall be constructed in accordance with the details shown on the subcontract Drawings unless otherwise directed by the contractor.

B. Line posts shall be set plumb and to the depth and spacing shown on the Subcontract Drawings.

c. Fence wire shall be stretched by mechanical stretcher or other device designed for such use. The length between pull posts shall not exceed 660 feet for woven wire.

* P.I.D. 06-S-17 
Concrete shall be placed around posts in a continuous pour. Each post shall be checked for vertical and top alignment, and shall be held in position during placement and rinishing operatiuns.

\subsection{MAINTENANCE AND REMOVAI}

The fence constructed under the subcontract shall be maintained during the term of the subcontract and later removed and disposed of as Subcontractor's property when no longer required.

\section{PART 4 - MEASUREMENT AND PAYMENT}

\subsection{MEASUREMENT}

A. Measurement for payment for furnishing and installing woven wire fence will be by the linear feet of fence installed as shown on the Subcontract Drawings. Measurements will be made along the top of the fence to the nearest foot.

B. Separate measurement for payment will not be made for relocation of existing woven wire fences.

\subsection{PAYMENT}

A. Payment for furnishing and installing woven wire fence will be by the unit price per linear foot quoted therefor in the Bid Schedule. Payment shall include full compensation for furnishing all labor, tools, equipment, and incidentals, and for performing all work involved in constructing fences, including any clearing, stripping, tree removal, excavation, concrete or cement, complete in place, including maintenance, removal and disposal, as shown on the subcontract Drawings and as accepted by the contractor.

B. Separate payment will not be made for relocation of existing woven wire fences. All costs for such work will be considered to be included in the related payment item for furnishing and installing woven wire fence specified in Article 4.1.A above.

END OF SECTION 02833

Document No. 3885-RFL-S-01-00746-04

Issued for Construction-Revision 1 


\section{SECTION 02835}

\section{DEER FENCE AND GATES}

\section{PART 1 - GENERAL}

\subsection{SCOPE}

[This specification section describes the requirements for furnishing, installing and removing deer fence including gates, posts, fittings and hardware.]*

\subsection{RELATED WORK}

A. Section 02832 - Chain Link Fence and Gates

B. Section 02833 - Woven wire Fence

\subsection{APPIICABLE PUBLICATIONS}

A. The publications listed below form a part of this specification to the extent applicable:

1. State of Colorado, Division of Highways:

a. Standard specifications for Road and Bridge Construction, 1986 Edition, (Colorado standard Specifications).

b. Standard Plans, $M \& S$ standards, January 1982 , (Colorado standard Plans).

\subsection{SHOP DRAWINGS}

Pursuant to the provisions of section 01300, three blackline or blueline prints and a reproducible transparency of fully detailed drawings of fence, gate and hardware, including footings and installation details, shall be submitted to the contractor for review.

\section{PART 2 - PRODUCTS}

2.1 MATERIALS

A. The materials shall conform to the following:

* P.I.D. 06-S-17 
1. Colorado standard specifications, sections 607.02, $710.01,710.02$ and 710.07 , as applicable.

a. Colorado standard specifications, section 607.02, Materials: Materials shall meet the requirements specified in the following subsection of section 700 - Materials:

$\begin{array}{ll}\text { Barbed Wire } & 710.01 \\ \text { Woven Wire } & 710.02 \\ \text { Fence Posts } & 710.07\end{array}$

2. Colorado Standard Plans, Drawings $\mathbf{M - 6 0 7 - 4}$, sheets 1 and 2 titled Deer Fence and Gate, as applicable.

\section{PART 3 - EXECUTION}

\subsection{INSTALLATION}

A. Installation of fencing shall be in accordance with the applicable portions of the colorado standard Plans and section 607.03 of the Colorado standard specifications and as specified below:

1. Colorado standard Specifications, Section 607.03, Construction Requirements:

a. Fence shall be constructed as shown on the subcontract Drawings or as staked.

b. Wire or fencing of the size and type required shall be firmly attached to the posts and braces in the manner indicated in Colorado standard Plans M607-4. All wire shall be stretched taut and be installed to the required spacing.

B. Installation of the deer gate shall be in accordance with the applicable portions of the Colorado standard Plans, and the subcontract Drawings.

\subsection{MAINTENANCE AND REMOVAL}

The fence and gates constructed under the subcontract shall be maintained during the term of the subcontract and later removed and disposed of as subcontractor's property when no longer required.

Document No. 3885-RFL-S-01-02082-03

Issued for Construction-Revision 1 


\subsection{MEASUREMENT}

A. Measurement for payment for furnishing and installing deer fence including posts will be by the linear feet of fence installed as shown on the subcontract Drawings. Measurements will be made along the top of the fence to the nearest foot.

B. Measurement for payment for furnishing and installing deer gate will be by the number of gates installed.

\subsection{PAYMENT}

A. Payment for furnishing and installing deer fence including posts will be by the unit price per linear foot quoted therefor in the Bid Schedule.

B. Payment for furnishing and installing deer gate will be by the unit price per each gate quoted therefor in the Bid schedule.

c. Unit prices quoted shall include full compensation for furnishing labor, materials, tools, equipment and accessories, and for performing all work including, but not limited to, clearing, stripping, tree removal, excavation, maintenance, removal and disposal of fence and gates.

END OF SECTION 02835

Document No. 3885-RFL-S-01-02082-03 


\section{SECTION 02935}

SEEDING

PART 1 - GENERAL

1.1 SCOPE

A. This specification section covers seeding for the restoration of the following areas:

1. Old Rifle Processing Site and Access Road Turnout

2. New Rifle Processing site including Wet Meadow/Shrub Wetlands

3. Estes Gulch Disposal site: Retention Basin, Access Control and Staging Area, and Access Road Turnout at Highway 13

4. Disturbed areas and earth materials stockpiles left inactive for 6 months or longer shall be seeded but not mulched.

1.2 WORK NOT INCLUDED

Seeding related to the restoration of off-site construction facilities including borrow areas is not included in the Scope of Work of this Section.

1.3 RELATED WORK

Section 02936 - Wetlands Revegetation

1.4 MATERIAL STORAGE

A. Seeds shall be stored in sealed waterproof containers in a cool, dry location and shall be kept out of direct sunlight until ready for use.

B. Fertilizer, if required, shall be delivered and stored in waterproof containers which will show the chemical analysis and name of manufacturer.

Document No. 3885-RFL-S-01-00747-03

Issued for Construction-Revision 0 


\section{PART 2 - PRODUCTS}

2.1 SEED MIX

A. Processing sites: The following seed mix shall be used for seeding of final grades except in the Wetlands:

1. Seed Species

Seeding Rate Pure Live seed

.

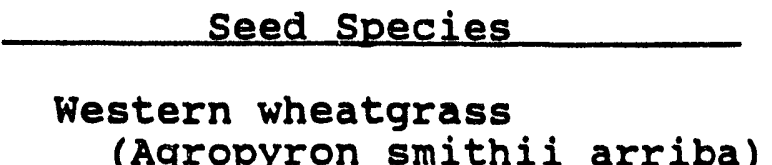
(Pounds Per Acre)

(Agropyron smithii arriba)

21.0

Tall wheatgrass

(Agropyron elongatum juse)

$\underline{27.0}$

Total

48.0

2. The seeding rates shown are for drill applied. These rates shall be increased by 100 percent if broadcasting method of application is used. Hydroseeding shall not be used.

B. Wet Meadow/Shrub Wetlands: The following seed mix shall be used for seeding as shown on the subcontract Drawings:

1. Salt Grass (Distichlis spicata)

Foxtail Barley (Hordeum jubatum) Alkalai Sacaton (Sporobolus airoides) Total
Seeding Rate

Pure Live Seed (Pounds Per Acre)

$$
16.0
$$

16.0

16.0

48.0

2. The seeding rates shown are for drill applied. These rates shall be increased by 100 percent if broadcasting method of application is used. Hydroseeding shall not be used.

Document No. 3885-RFL-S-01-00747-03

Issued for Construction-Revision 0 
c. Wetlands Buffer zone: The following seed mix shall be used for seeding as shown on the subcontract Drawings:

1. Seed species

seeding Rate Pure Live Seed

\section{Salt Grass}

(Distichlis spicata)

$$
16.0
$$

Great Basin Wild Rye

(Elymus cinereus)

$$
16.0
$$

Alkalai Sacaton

(Sporobolus airoides)

16.0

Total

$$
48.0
$$

2. The seeding rates shown are for drill applied. These rates shall be increased by 100 percent if broadcasting method of application is used. Hydroseeding shall not be used.

D. Disposal site: The following seed mix shall be used for seeding of final grades:

Seeding Rate Pure Live Seed

1. Seed species (Pounds Per Acre)

\section{Western wheatgrass}

(Agropyron smithii arriba) $\quad 16.0$

Bluebunch wheatgrass

$\begin{array}{ll}\text { (Agropyron spicatum) } & 19.0\end{array}$

Indian ricegrass

(Oryzopsis hymenoides paloma) $\quad 12.5$

Total

47.5

2. The seeding rates shown are for drill applied. These rates shall be increased by 100 percent if broadcasting method of application is used. Hydroseeding shall not be used.

\subsection{ACCEPTANCE OF SEED}

[A. The subcontractor shall only use seed which has been certified by the Colorado Department of Agriculture.]*

[B.]* Final acceptance of seed will be made by the contractor based on the following: seed shall be furnished sepa-

* Revision 
rately or in mixture in standard sealed containers with the following information provided by the seed vendor on each seed container label: (1) seed name; (2) lot number; (3) net weight; (4) percentages of purity and of germination; (5) seed coverage, in acres, on a pure live seed basis; and (6) percentage of maximum weed seed content clearly marked for each kind of seed. Seeds shall be packaged by the vendor in even acre coverage containers. The subcontractor shall furnish the Contractor duplicate copies of a statement by the vendor, certifying that each lot of seed has been tested by a recognized laboratory for seed testing within 6 months of date of delivery. This statement shall include: (1) name and address of laboratory, (2) date of test, (3) lot number for each kind of seed, and (4) results of tests as to name, percentages of purity and of germination, and percentage of weed content, for each kind of seed furnished, and, in case of a mixture, the proportions of each kind of seed.

\subsection{FERTILIZER}

Fertilizer, if required, shall be a standard commercial grade and provide the nutrients as determined by the soils fertility analysis specified in Article 3.1.C. Fertilizer shall be furnished in new, clean, and sealed containers with the name, weight, and guaranteed analysis of contents clearly marked. A liquid form of fertilizer providing the nutrients as determined by the soils fertility analysis specified in Article 3.1.C may be used. If the fertilizer is delivered in bulk, the subcontractor shall submit to the contractor, for each load, a certificate from the manufacturer or supplier indicating the above-mentioned information.

\subsection{MULCH}

Mulch shall consist of grass hay. Mulch shall be free from all viable seed, mold, or other objectionable material. Final acceptance of mulch will be by the contractor.

\subsection{WATER}

Water used in the planting or care of vegetation shall be free of oils, acids, alkalies, salts, or any substance injurious to plant life. 


\subsection{TOPSOIL}

Topsoil for seeding of disturbed areas within the state of Colorado Highway Department rights-of-way shall conform to Section 207 of the Colorado Standard Specifications.

PART 3 - EXECUTION

\section{1 PREPARATION}

A. [Timing of Seeding: All final grades not covered by gravel or riprap shall be seeded in accordance with the schedule set forth in section 212.03 of the colorado Department of Highways standard specifications.] * Seeding materials shall not be applied during windy weather, when the ground is excessively wet except in Wet Meadow/Shrub Wetlands, or frozen, or when snow is present. If the ground is wet in the Wet Meadow/Shrub Wetlands, broadcast method of application shall be used.

B. Grading and seedbed Preparation: Before applying seed in a given area, any stockpiled topsoil and select fill shail be put in place and the area shall be graded as shown on the Subcontract Drawings. Processing and Disposal site surfaces, except Wet Meadow/Shrub Wetlands, shall be graded to slope gradually towards drainage courses, with no enclosed low spots where water can accumulate. The Wet Meadow/Shrub Wetlands shall be graded to provide undulating surfaces for water accumulation. Areas to be seeded that have been damaged by erosion or other causes shall be restored prior to seeding and then cultivated to provide a reasonably firm but friable seedbed. A minimum of 6 inches of surface soil shall be in a loose condition at the time of fertilizer and seed application.

c. Enrichment: Micronutrient fertilizer requirements, if any, shall be determined by laboratory soils fertility analysis of representative soil samples from each of the following project areas: old Rifle processing site, New Rifle processing site and Estes Gulch disposal site. The Subcontractor shall collect representative soil samples and have them analyzed by a certified soil laboratory. A copy of the laboratory report shall be submitted to the contractor for approval prior to application of fertilizer or seed. 


\subsection{APPLICATION}

A. Seed shall be applied by a rangeland drill to a depth of 0.50 to 0.75 inch and at a spacing of not more than 7 inches. To the greatest extent possible, seeding shall be oriented along (parallel to) land contours. For slopes too steep or soils too moist to use a drill, a mechanical broadcaster may be used and the seed raked in.

B. [Within 2 hours of application of seeding, mulch shall be applied at a rate of 1 ton per acre to all areas seeded, and the mulch shall be crimped with a mulch crimper.]*

[3.3 PLANT ESTABLISHMENT

The subcontractor shall be responsible for ensuring that adequate vegetative cover is established.]*

\section{[3.4]*CARE DURING CONSTRUCTION}

The subcontractor shall be responsible for protecting and caring for areas seeded before final acceptance of the work. The subcontractor shall repair any damage to seeded areas caused by erosion or construction operations without additional compensation.

\section{PART 4 - MEASUREMENT AND PAYMENT}

\subsection{MEASUREMENT}

A. Measurement for payment for the following items of seeding will be by acreage actually seeded and approved:

1. Seeding of Processing sites.

2. Seeding of Estes Gulch Disposal Site.

3. Seeding of Wet Meadow/Shrub Wetlands.

4. Seeding of Wetlands Buffer Zone.

B. Separate measurement for payment will not be made for any incidental work and services; e.g., loosening the surface, applying fertilizer, mulching, watering, and erosion repair related to seeding.

\subsection{PAYMENT}

Payment for seeding items mentioned in Article 4.1.A above will be by their applicable unit prices per acre quoted therefor in the Bid schedule. The prices quoted shall include full compensation for furnishing all materials, tools, equipment, incidentals, labor, and for performing all work specified herein for complete work.

* Revision

END OF SECTION 02935

Document No. 3885-RFI-S-01-00747-03

Issued for Construction-Revision 0 


\section{SECTION 02936}

\section{WETLANDS REVEGETATION}

\section{PART 1 - GENERAL}

\subsection{SCOPE}

A. This Specification Section covers the furnishing and planting of bare root plants, native transplants and rhizomes (plants) in the wetlands at the New Rifle processing site, adjacent to the Colorado River (wetlands), as shown on the subcontract Drawings and as specified in this section.

B. The planting locations of each species of plant shall be as shown on the subcontract Drawings.

1.2 WORK NOT INCLUDED

seeding of the wetlands.

1.3 RELATED WORK

Section 02935 - Seeding

\subsection{APPLICABLE PUBLICATIONS}

A. The publications listed below form a part of this specification to the extent applicable:

1. State of Colorado, Division of Highways:

a. Standard specifications for Road and Bridge Construction, 1986 Edition, (Colorado Highway Specifications).

b. Division of Highways, M S Standards, January 1982, (Colorado Standard Plans).

2. American standard for Nursery stock

3. U.S. Department of Agriculture Publications

Document No. 3885-RFI-S-01-02941-01

Issued for Construction-Revision 0 Wetlands Revegetation 
1.5 SHIPPING, HANDLING AND STORAGE

A. Plants shall be dug, properly pruned and prepared for transport, in accordance with recognized standard practice, as close as possible to the date of planting so as to minimize the period of storage. The root system shall be kept moist and plants shall be protected from adverse conditions due to climate during transportation.

B. If storage is necessary, bare rcot plants and native transplants shall be kept in cool conditions. The plants shall be placed root to root, covered with a wood chip mulch and a tarpaulin or similar cover. The plants shall be watered at least 3 times a day, depending on climatic conditions.

C. If storage is necessary for rhizomes, they shall be covered with burlap and watered at least 3 times a day, depending on climatic conditions.

PART 2 - PRODUCTS

\subsection{PLANTS}

A. The plants listed in Table 02936-A shall be used for revegetation of the wetlands.

B. Bare root plants shall be conservation grade representatives of the specified specie or variety, in healthy condition with normal well developed root systems, shall be free of all objectionable features, and shall conform to the requirements of the current "American standard for Nursery stock". Native transplants shall be pruned to 6 inches long and dug carefully to avoid removing too much root or soil from around the root.

C. Plants shall be free from diseases and insect pests.

D. Native transplants and rhizomes shall be obtained by subcontractor from U.S. Army Corps of Engineers approved local sources. Bare root plants shall be obtained, where possible, from local nurseries. The subcontractor may wish to obtain the required size and number of bare root species from a Certified Nursery.

E. The Subcontractor shall notify the contractor of the source he intends to use prior to plant acquisition and

Document No. 3885-RFL-S-01-02941-01

Issued for Construction-Revision 0 Wetlands Revegetation 
obtain the Contractor's approval before commencing the plant acquisition work.

F. Any depressions or holes remaining following acguisition of native transplants and rhizomes shall be backfilled to original conditions.

\subsection{ACCEPTANCE OF PLANTS}

A. Final acceptance of the plants by the contractor will be based on the following:

1. Plants shall conform to the size requirements specified in Table 02936-A.

\subsection{ADDITIONAL MATERIAL REQUIREMENTS}

A. Mulch: Wood chip shall be approximately $1 / 4$ inch to $1 / 2$ inch wide and 3 inches to 4 inches long.

B. Wire Mesh: Wire mesh shall be installed around all singly planted cottonwoods and around all clumps of planted cottonwoods and willows to protect against damage by encroaching deer. Standards of material and installation shall be in accordance with the relevant U.S. Department of Agriculture specifications and American Standard for Nursery stock.

\section{PART 3 - EXECUTION}

\subsection{GENERAL}

A. The subcontractor shall plan his work in accordance with the requirements for monitoring and maintenance specified in Article 3.3 .

B. Planting, watering and maintaining the plants shall conform to the applicable provisions of the colorado Highway Specifications, Colorado standard Plan M-214-1, and as specified in this section. Work shall be done in accordance with good horticultural practices.

c. Plants shall be protected at all times from drying out or other injuries. Broken and damaged roots shall be pruned before planting.

Document No. 3885-RFL-S-01-02941-01

Issued for Construction-Revision 0 Wetlands Revegetation 
D. Planting areas shall be graded to the lines and grades indicated on the subcontract Drawings, or as approved by the Contractor.

3.2 EXCAVATION, PLANTING AND BACKFILLING

A. Planting style:

1. Cattails shall be planted randomly within the cattail wetlands.

2. Sand Bar Willows shall be planted in randomly spaced clumps of three to four bare root plants or native transplants. The clumps shall be planted in the upper reaches of the Wet Meadow/Shrub Wetlands but in general not as close to the perimeter as the cottonwoods.

3. The cottonwoods shall be planted in randomly spaced clumps of four to five bare root plants or native transplants. Plants shall be spaced 50 feet to 100 feet apart within the clumps. The clumps shall be spaced 200 feet to 300 feet apart along the north perimeter of the Wet Meadow/Shrub Wetlands. Occasional single plants shall be planted, generally along the north and northwestern perimeter of the Wet Meadow/Shrub Wetlands, 150 feet to 200 feet apart.

B. Excavation: Planting pits shall be circular in outline with vertical sides. Pits for the willows and cottonwoods shall be at least 12 inches in diameter. Pits shall be dug so that the distance from the bottom of the root system of a plant to the bottom of the pit shall be at least 6 inches for the willows and cottonwoods.

c. Planting:

1. Plants shall be set plumb to the ground surface.

2. Plants with a partially dry root system shall be soaked in water for a period of eight hours before planting. Plants with dry roots will be rejected.

3. At the time of planting, pits shall be soaked in water.

D. Backfilling:

1. Backfill shall be thoroughly worked and watered-in to eliminate air pockets. Roots and crown shall be

Document No. 3885-RFL-S-01-02941-01

Issued for Construction-Revision 0 Wetlands Revegetation 
covered with soil to form a mound at least 2 inches higher than the surrounding soil. After the soil has settled, plants shall be in the specified position and depth.

2. When planting is complete, the mound shall be covered with a 4-inch thick layer of fresh moist wood chip mulch. After completion of planting and before acceptance of the work, the subcontractor shall again water thoroughly all plants installed under this subcontract. Plants damaged by the subcontractor's operations shall be replaced at his expense.

\subsection{MAINTENANCE AND MONITORING}

A. Maintenance: For a period of three years after the completion of planting and seeding, the subcontractor shall be responsible for plant maintenance at no extra cost to the contractor. The subcontractor shall employ all means practicable to preserve the plants in a healthy and vigorous growing condition including the following:

1. Replacement of all dead or damaged plants as required within 30 days of notification by the contractor. Replacement stock and materials shall be subject to all the requirements specified for the original stock and materials.

2. Reshaping mounds for plants, replacement of wood-chip mulch, and keeping all planting reasonably free from thistle and tamarisk, and all other work as necessary to maintain the plants in healthy growing condition.

B. An annual vegetation monitoring report shall be made for three years on or before * and submitted to the Corps of Engineers (COE) on or before __ * (*note: the date shall be included on receipt of the completed '404' Dredge and Fill Permit). The report shall be in the form of photographs or layout drawings indicating the dimensions of plant growth for each shrub and plant or a representative random sample of each species. The growth shall be indicated by the diameter of the drip line and by the height of the shrub and plant. The report shall also include the percentage survival rate of each species and the percent ground cover of grasses. The report shall be submitted to the COE at the following address: 
U. S. Army Corps of Engineers

Regulatory Unit Four

764 Horizon Drive

Grand Junction, Colorado 81506

Attn: Mr. Grady MeNure

A copy of the report shall be submitted to the contractor.

PART 4 - MEASUREMENT AND FAYMENT

4.1 MEASUREMENT

A. Measurement for payment for the following items of revegetation will be by the number of each type planted as shown on the Subcontract Drawings:

1. Sandbar Willow (Salix exigua)

2. Cottonwood (Populus deltoides)

3. Cattail (Typha latifolia)

4.2 PAYMENT

Payment for the items of Article 4.1. A above will be by their applicable unit prices per each type quoted therefor in the Bid Schedule. Prices quoted shall include full compensation for furnishing all materials, equipment, tools, accessories, incidentals and for performing all work including, but not limited to, clearing, site preparation, planting, watering, maintaining, etc. complete as specified.

END OF SECTION 02936

Document No. 3885-RFL-S-01-02941-01

Issued for Constriction-Revision 0 


\section{Division 3}

Concrete 


\section{SECTION 03000}

\section{CONCRETE WORK}

\section{PART 1 - GENERAL}

\subsection{SCOPE}

This Specification Section covers concrete work required for the following:

1. Construction of concrete plug in a 48-inch diameter steel pipe casing at the old Rifle processing site.

[Text Deleted]*

[2.]* Construction of concrete decontamination pads at old Rifle, New Rifle and Estes Gulch sites.

[3.]* Concrete for base of monitoring wells at Estes Gulch site.

1.2 RELATED WORK

A. Section 01300 - Submittals

B. Section 02050 - Demolition

\subsection{APPLICABLE PUBLICATIONS}

A. The Publications listed below form a part of this specification to the extent referenced. The Publications are referred to in the text by the basic designation only:

1. American Concrete Institute (ACI):

301-84 Specifications for structural concrete for Buildings; Supplement - 1985

2. American Society for Testing and Materials (ASTM):

C94-86 Ready-Mixed Concrete (Rev. B)

c171-69 Sheet Materials for Curing Concrete

(R 1986)

* P.I.D. 06-S -17

Document No. 3885-RFL-S-01-00748-03

Issued for Construction-Revision 1

Concrete work

RFL-PH-II 
$[0173-78$

C231-89a
Test Method for Air Content of Freshly Mixed Concrete by the Volumetric Method

Test Method for Air Content of Freshly Mixed Concrete by the Pressure Method]*

\subsection{QUALITY ASSURANCE}

A. Work shall be performed in accordance with ACI 301.

B. Materials shall be obtained from the same source throughout the completion of concrete work.

1.5 TESTS

A. Three concrete test cylinders shall be taken for every 50 or less cubic yards of concrete placed each day unless otherwise required by the contractor.

B. One additional test cylinder shall be taken during cold weather and be cured on site under the same conditions as the concrete it represents.

c. [One slump test and one air content test shall be taken for each set of test cylinders taken.]* Additionally one slump test shall be taken for each truckload of concrete used.

D. The Subcontractor shall be responsible for carrying out these tests and reporting the test results to the contractor in a timely manner.

[E. The Contractor may vary the number or frequency of tests, as he deems necessary.]*

\section{PART 2 - PRODUCTS}

\subsection{CONCRETE MATERIALS}

Concrete materials shall conform to ASTM C94, Type II cement.

2.2 CONCRETE QUALITY

A. Proportioning of concrete mixes to meet the requirements specified below shall be the subcontractor's responsibility:

1. Compressive strength: Compressive strength in 28 days shall be 3,000 psi minimum.

* P.I.D. 06-S-17 
2. Entrained-Air Content: Entrained-air content of exterior concrete shall be maintained at 5 to 7 percent by volume of concrete.

3. Slump: Slump shall be 4 to 6 inches.

\section{PART 3 - EXECUTION}

\subsection{PLACING}

A. Placement of concrete shall conform to ACI 301 .

B. Concrete shall be placed on clean surfaces that are thoroughly moistened. Concrete shall be protected from freezing.

\subsection{CONSOLIDATION OF CONCRETE}

Consolidation of concrete shall be with internal concrete vibrators supplemented where appropriate by handspading, rodding, and tamping. Vibrating equipment shall be adequate to thoroughly consolidate the concrete.

\subsection{CURING}

Curing shall start as soon as free water has disappeared from concrete surfaces after placing and finishing. curing materials shall be applied and maintained so as to protect the concrete from moisture loss for 7 days. Curing shall be accomplished by impervious sheet or membrane-forming curing compound. Concrete surfaces shall be thoroughly wetted before covering with impervious-sheet materials. Membraneforming curing compound shall be applied with mechanical spraying equipment at a coverage of not more than 300 square feet per galion. Surfaces damaged during curing shall be resprayed.

\section{PART 4 - MEASUREMENT AND PAYMENT}

\subsection{MEASUREMENT}

A. Measurement for payment for the following items of concrete work will be by the cubic yards of concrete furnished and placed.

1. Construction of concrete plug in a 48-inch diameter steel pipe casing at the old Rifle processing site. 
[Text Deleted]*

\subsection{PAYMENT}

A. Payment for the items of Article 4.1.A above will be the unit price per cubic yard of concrete quoted therefor in the Bid schedule. The price quoted shall include full compensation for furnishing all labor, materials, equipment, tools and accessories including cement, admixtures and pozzolan if used, fine and coarse aggregates, formwork, and for performance of all work as indicated on the subcontract Drawings, as specified in these specifications, and as required by the contractor.

B. Payment for concrete decontamination pads at old Rifle, New Rifle and Estes Gulch sites will be included in the respective Bid Schedule items of section 01500 .

c. Payment for concrete for base of dewatering wells at Estes Gulch site will be included in the respective Bid schedule item of section 02144 .

END OF SECTION 03000

* P.I.D. 06-S-17

Document No. 3885-RFL-S-01-00748-03

Issued for Construction-Revision 1 
Subcontract Drawings 
DATE FILMED 7121193 